\title{
COMPARAÇÕẼS ENTRE MÉTODOS QUANTITATIVOS E MÉTODOS BASEADOS EM MARCADORES RAPD PARA A PREDIÇÃO DO COMPORTAMENTO DE POPULAÇŌES DE SOJA
}

\author{
Paulo Augusto Vianna Barroso \\ Engenheiro Agrônomo
}

Orientador: 'Prof. Dr. ISAIÁAS OLIVIOO GERALDI

\begin{abstract}
Tese apresentada à Escola Superior de Agricultura "Luiz de Queiroz", Universidade de São Paulo, para obtenção de título de Doutor em Agronomia, Área de Concentração: Genética e Melhoramento de Plantas
\end{abstract}

PIRACICABA

Estado de São Paulo - Brasil

Janeiro - 2000 


\section{Dados Internacionais de Catalogação na Publicação (CIP) DIVISÃo DE BIBLIOTECA E DOCUMENTAÇÃO - Campus "Luiz de Queiroz"/USP}

Barroso, Paulo Augusto Vianna Comparaçōes entre métodos quantitativos e métodos baseados em marcadores RAPD para a prediçāo do comportantento de populaçôes de sojia /, Paulo Augusto Vianna Barroso. - - Piracicaba, 2000.

162 p. : il.

Tese (doutorado) - - Escola Superior de Agricultura Luiz de Queiroz, 1999. Bibliografia

1. Cruzamento vegetal 2. Diversidade genética 3. Endogamia 4. Genética de populaçāo 5 . Grão 6. Linhagem vegetal 7. Marcador molecular 8. Melhoramento genético vegetal 9. Predição 10. Soja I. Título

CDD 633.34

"Permitida a cópia total ou parcial deste documento, desde que citada a fonte - O Autor" 


\section{ERRATA}

1) Página 37, item 3.8.2 - onde se lê 1,5 unidades de Taq DNA polimerase, leia-se 1 microlitro de Taq DNA polimerase purificada segundo PLUTHERO (1993) a partir de E. coli INVALPHAF'contendo o plasmídeo ttaq e diluída 1:20 (suficiente para que o padrão de amplificação fosse semelhante ao obtido com 1,5 unidades de taq DNA polimerase comercial).

PLUTHERO, F.G. Rapid purification of high-activity taq DNA polymerase. Nucleic Acid Research, v. 21, n.20, p.4850-4851, 1993.

2) Página 39 - onde se lê $\sigma_{\boldsymbol{D} G i j(k)}^{2}=\frac{\sum_{1}^{m}\left(\overline{D G}_{i j(k)}-D G_{i j n(k)}\right)^{2}}{m-1}$, leia-se $\sigma_{D G i j(k)}^{2}=\frac{\sum_{1}^{m}\left(\overline{D G} i j(k)-D G_{i j m(k)}\right)^{2}}{m-1}$

3) Tabela 3 da página 43, Tabela 5 da página 44, Tabela 7 da página 45, Tabela 9 da página 46 e Tabela 11 da página 47 - onde se lê DF, leia-se GL.

4) Tabela 21 da página 62 e Tabela 23 da página 64 - omde se lê $Q M^{\star} 10^{3}$, leia-se QM multiplicado por $10^{3}$. 
- Aos méus pais Geraldo e Antonia

À Lúcia, gentil companheira

E, principalmente, ao pequeno Guilherme

Dedico 


\section{AGRADECIMENTOS}

Agradeço a todos que contribuiram para que este trabalho fosse realizado, e em especial:

- Ao Prof. Dr. Isaias Olívio Geraldi, pela orientação e pela cessão dos dados experimentais que possibilitaram a realização deste trabalho.

- À Prof. Dra. Maria Lúcia Carneiro Vieira pela co-orientação informal e por disponibilizar seu laboratório para que os marcadores fossem obtidos.

- À CAPES pela bolsa fornecida durante a realização do curso

- Ao Prof. Dr. Carlos Tadeu dos Santos Dias e ao Prof. Dr. Roland Vencovsky pelo auxilio nas análises bootstrap.

- Ao Biólogo Carlos Alberto de Oliveira pelo auxílio nos trabalhos de laboratório.

- Ao Sr. José Fernandes de Araújo e ao Sr. Gustavo Perina pelo auxilio na condução dos experimentos.

- Aos funcionários de campo do Departamento de Genética da ESALQ/USP que auxiliaram no plantio, condução e colheita dos experimentos.

- À Msc. Lúcia Vieira Hoffmann e ao Dr. Luciano Nass pela leitura dos originais.

- Às funcionárias do DIB ESALQ/USP Elizabeth, Silvana e Silvana Marchezelli pela solicitude e paciência.

- Ao Dr. Carlos Eduardo Pulcinelli pela disponibilização de parte dos programas de computador e dados utilizados neste trabalho.

- Ao Dr. Romeu Kiihl pelo fornecimento da genealogia de duas linhagens. 


\section{Sumário}

Resumo

vii

Summary

ix

1. Introdução

2. Revisão de Literatura

2.1 Predições em populações endogâmicas formadas utilizando genótipos não adaptados como genitores

2.2 Predição do potencial de populações $\quad$............................................ 7

2.2.1 Predição com base na genealogia dos genitores $\ldots \ldots \ldots \ldots \ldots . . . . .4$

2.2.2 Predição com base em estimativas de distância genética obtidas a partir de marcadores morfológicos e/ou caracteres quantitativos

2.2.3 Predição com base na avaliação em gerações precoces ...... 14

2.2.4 Predição com base na média dos genitores ..................... 16

2.2.5 Predição com base em distâncias genéticas estimadas a partir de marcadores moleculares

2.3 Partição da distância genética

3. Material e Métodos

3.1 Caracterização do ambiente de experimentação

3.2 Material genético 26

3.3 Avaliação experimental das linhagens genitoras 29

3.4 Avaliação das populações endogâmicas .... 30

3.5 Análise dialélica 32

3.5.1 Dialelo incluindo as 25 populações

3.5.2 Dialelo parcial incluindo apenas as populações derivadas do cruzamento de linhagens adaptadas com não adaptadas

3.5.3 Análise dialélica da geração $F_{2}$

3.6 Proporção de linhagens superiores

3.7 Calculo da distância euclidiana

3.8 Avaliação dos genitores com marcadores moleculares RAPD 36

3.8.1 Extração do DNA 
3.8.3 Cálculo da distância genética …….................................. 37

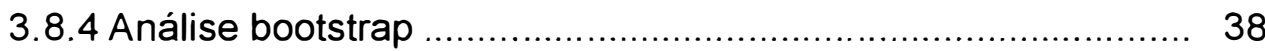

3.9 Partição das distâncias genéticas em distância genética geral e distância

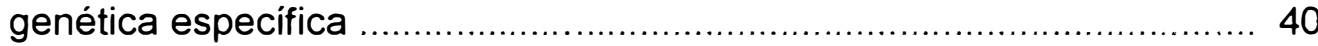

3.9.1 Partição das distâncias genéticas considerando todas as 28 combinações entre genitores

3.9.2 Partição das distâncias genéticas considerando as 15 combinações entre genitores adaptados e não adaptados

4. Resultados e Discussão

4.1 Análise das linhagens genitoras

4.1.1 Produção de grãos 42

4.1.2 Altura das plantas na maturação 43

4.1.3 Número de dias para a maturação 44

4.1.4 Altura das plantas no florescimento ...................................... 46

4.1.5 Número de dias para o florescimento .................................... 47

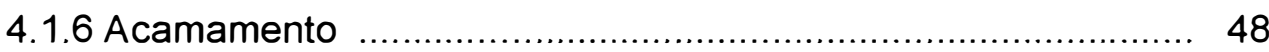

4.1.7 Considerações a respeito das avaliações das linhagens genitoras

4.2 Distância euclidiana entre as linhagens genitoras

4.2.1 Partição da distância euclidiana considerando todas as 28 combinações entre genitores

4.2.2 Partição da distância euclidiana, considerando as 15 combinações entre genitores adaptados e não adaptados 52

4.3 Avaliação dos genitores com marcadores moleculares RAPD 53

4.3.1 Distância genética entre as oito linhagens 55

4.3.2 Estimativa das distâncias gerais e especificas considerando a existência de um grupo de genitores

4.3.3 Estimativa das distâncias gerais e específicas considerando a existência dois grupos de genitores 59

4.4 Dialelo na geração $F_{2}$ 60

4.4.1 Dialelo considerando todas as populações 60

4.4.2 Dialelo parcial considerando a existência de dois grupos de genitores 62

4.5 Análise de variância das populações endogâmicas 65

4.6 Análise dialélica considerando todas as 25 populações 
4.7 Análise dialélica parcial considerando a existência de dois grupos de genitores 79

4.8 Análises de variância de progênies dentro de populações e estimativas da variância genética entre populações 85

4.9 Proporção de progênies superiores observadas nas populações $\quad$........ 89

4.10 Predições a respeito do comportamento das 25 populações endogâmicas

4.10.1 Capacidade preditiva da média dos genitores .................. 95

4.10.2 Capacidade preditiva do dialelo realizado na geração $F_{2} \ldots \ldots .97$

4.10.3 Capacidade preditiva da distância euclidiana ................... 100

4.10.4 Capacidade preditiva da distância euclidiana geral e específica 104

4.10.5 Capacidade preditiva distância genética medida por marcadores RAPD 106

4.10.6 Capacidade preditiva distância genética geral e da distância genética específica

4.11 Considerações a respeito das predições realizadas para todas as 25 populações

4.12 Predições a respeito do comportamento das 14 populações endogâmicas formadas pelo cruzamento entre genitores adaptados com não adaptados

4.12.1 Capacidade preditiva da média dos genitores 116

4.12.2 Capacidade preditiva do dialelo parcial em $F_{2}$ 118

4.12.3 Capacidade preditiva da distância euclidiana 121

4.12.4 Capacidade preditiva da distância euclidiana geral e específica

4.12.5 Capacidade preditiva da distância genética baseada em marcadores RAPD

4.12.6 Capacidade preditiva da distância genética geral e da distância genética especifica

4.13 Considerações sobre as predições realizadas a respeito do genitor não adaptado mais adequado

5. Conclusões

6. Referências Bibliográficas

7. Apêndice 


\section{COMPARAÇÕES ENTRE MÉTODOS QUANTITATIVOS E MÉTODOS BASEADOS EM MARCADORES RAPD PARA A PREDIÇÃO DO COMPORTAMENTO DE POPULAÇÕES DE SOJA}

Autor: Paulo Augusto Vianna Barroso Orientador: Prof. Dr. Isaias Olivio Geraldi

RESUMO

Este estudo comparou a distância genética baseada em marcadores RAPD com a média dos genitores, a distância euclidiana e a capacidade geral de combinação estimada em $F_{2}$, quanto a: a) eficiência das predições do potencial de populações endogâmicas de soja; b) eficiência na escolha de linhagens não adaptadas a serem utilizadas como genitoras doadoras em programas de melhoramento. As populações empregadas foram obtidas pelo cruzamento biparental entre oito linhagens, cinco adaptadas e três não adaptadas. Para o primeiro objetivo foram utilizadas todas as 25 populações disponiveis e para o segundo apenas as 14 formadas pelo cruzamento entre genitores adaptados com não adaptados. $O$ potencial das populações foi avaliado pela proporção de progênies com médias superiores à média de todas as 493 progênies utilizadas. Os caracteres avaliados foram: produção de grãos, altura das plantas na maturação, altura das plantas no florescimento, número de dias para o florescimento, número de dias para a maturação e acamamento. De modo geral, os melhores métodos preditivos foram a média dos genitores e a capacidade geral de combinação estimada na geração $F_{2}$. A distância genética foi capaz de realizar predições com confiabilidade semelhante a estes métodos em parte dos caracteres, entre os quais se inclui a produção de grãos. A distância genética geral apresentou capacidade preditiva ainda mais alta, mostrando que a partição da distância genética baseada em marcadores RAPD pode ser recomendada para situações semelhantes às existentes neste estudo. Conclui-se que a distância genética baseada em marcadores RAPD e a distância genética geral podem ser utilizadas como métodos preditivos para selecionar genitores de populações mais promissoras e para identificar a linhagem não adaptada mais adequada, principalmente quando as linhagens não foram avaliadas em 
experimentos ou então quando as predições são necessárias em um curto espaço de tempo 


\section{COMPARISON OF QUANTITATIVE AND RAPD BASED METHODS FOR PREDICTION OF SOYBEAN POPULATIONS PERFORMANCE}

Author: Paulo Augusto Vianna Barroso

Adviser: Prof. Dr. Isaias Olívio Geraldi

SUMMARY

This research was carried out to compare the genetic distance based on RAPD markers with the parental means, the Euclidian distance and the general combining ability in $F_{2}$, as for: a) effectiveness of the predictions conceming to the breeding potential of the inbred soybean populations; $b$ ) effectiveness in the selection of the nonadapted lines to be used as parents in breeding programs. The populations used were obtained by biparental hybridization among eight inbred lines, five adapted and three non adapted. For the first objective all the 25 populations available were used and for the second only the populations formed by the hybridization between adapted parents and non adapted parents. The potential of the populations was measured by the proportion of progenies with higher means than the general mean of all 493 progenies used. The traits evaluated were: seed yield, plant height at maturity, plant height at flowering, days to flowering, days to maturity and lodging. The parental means and general combining ability were the best methods of prediction for almost all the traits. The genetic distance was able to predict the best non-adapted line and the inbred populations performance for some traits (including seed yield) with almost the same security of the parents mean and general combining ability. The partition of the RAPD based genetic distance, and the use of the general genetic distance increased the prediction ability. The results showed the genetic distance based on RAPD markers and the general genetic distance can be used to predict the parental combinations that would result in more promising populations, and to identify the more appropriate nonadapted lines to be used in introgression programs. The genetic distance based on RAPD would be more useful when the lines should not have been evaluated previously in experiments or when the predictions are necessary in a short period of time. 


\section{INTRODUÇÃO}

A soja, Glycine max (L.) Merrill, é u ma espécie autógama cultivada em todas as regiões brasileiras. Embora seus grãos sejam pouco consumidos in natura, ela está presente em nossa alimentação cotidiana. O óleo extraído de seus grãos é o mais utilizado no Brasil, sendo consumido na forma de óleo de cozinha e em alimentos com maior processamento industrial, como margarinas e embutidos. Os grãos de soja possuem alta concentração de proteína, que é utilizada, principalmente, na alimentação animal. A soja é também um importante produto de exportação brasileiro, sendo comercializada na forma de grãos e em formas um pouco mais elaboradas.

O cultivo da soja no Brasil se restringiu a região Sul durante muitas décadas. Sua expansão para as demais regiões do pais só foi possivel graças ao grande empenho dos melhoristas na produção de cultivares adaptadas às condições ambientais existentes em locais de menor latitude.

As seleções nos programas de melhoramento desta espécie são normalmente realizadas em populações endogâmicas, obtidas através de hibridações artificiais, seguidas por alguns ciclos de autofecundações. Muitas populações endogâmicas são formadas e avaliadas anualmente, mas nem todas possuem potencial suficiente para que genótipos com desempenho superior sejam selecionados e liberados como cultivares. Até que se determine se a população possui potencial para produzir genótipos superiores, parte dos recursos materiais e humanos disponiveis para 0 programa já foram consumidos com sua obtenção e avaliação.

O conhecimento prévio do comportamento de populações pode aumentar muito a eficiência dos programas de melhoramento, evitando que populações pouco promissoras sejam formadas ou eliminando-as em estágios iniciais do processo de 
endogamia. Diversos métodos de predição do comportamento de populações foram desenvolvidos. Os procedimentos descritos na literatura se baseiam, principalmente, na avaliação genealógica dos genitores, no desempenho per se dos genitores, na utilização de delineamentos genéticos especificos para estimar parâmetros em gerações precoces e na obtenção de estimativas de diversidade entre os genitores.

Com o advento dos marcadores moleculares, novas metodologias de predição foram propostas. Elas se baseiam em estimativas da distância genética obtidas a partir das diferenças existentes ao nível do DNA entre genótipos candidatos a genitores. Estes métodos têm sido apontados na literatura como "poderosas ferramentas", embora os resultados publicados até o momento sejam inconsistentes. Portanto, seu real potencial não está determinado e somente será conhecido após extensiva experimentação.

A incorporação destes métodos preditivos na rotina dos programas de melhoramento genético de soja, ou de qualquer outra espécie, somente deve ser realizada caso eles apresentem potencial preditivo maior ou similar aos métodos existentes.

Buscando auxiliar a aplicação destas novas metodologias, o presente trabalho visou comparar o desempenho de métodos tradicionais de predição e métodos baseados nas informações fomecidas por marcadores RAPD (Random Amplified Poplymorphic DNA) quanto à:

a) Eficiência preditiva do potencial de populações endogâmicas de soja formadas através de cruzamentos biparentais;

b) Eficiência na escolha de linhagens não adaptadas a serem utilizadas em programas de melhoramento de soja. 


\section{REVISÃO DE LITERATURA}

2.1 Predições em populações endogâmicas formadas utilizando genótipos não adaptados como genitores

Quando se pretende trabalhar com populações segregantes visando objetivos convencionais do melhoramento de plantas autógamas (maior produção, menor acamamento, etc), o ideal é realizar a seleção de linhagens endogâmicas em populações que apresentam média e variância genética altas (Cox et al., 1985). Temse obtido populações com médias altas utilizando genitores com desempenho per se superior. Neste caso, o potencial de populações típicas de melhoramento diferem entre si, principalmente com relação à variância genética.

Se a variância genética é o parâmetro mais importante em programas convencionais de melhoramento, as predições a respeito do potencial das populações que estes programas utilizam devem ser dirigidas à variância.

Segundo Falconer \& Mackay (1996), a variância genética aditiva de um dado loco com dois alelos em uma população segregante é dada por:

$$
V_{A}=2 p q[a+d(q-p)]^{2}
$$

onde: $V_{A}$ é a variância aditiva; a é o componente genético aditivo, que correponde ao afastamento de cada homozigoto da média; $d$ é o componente genético dominante, que corresponde ao afastamento do heterozigoto da média, p é a freqüência de um alelo e q a freqüência do outro alelo. 
Em uma população endogâmica qualquer, os valores de dominância são nulos $(d=0)$. Se esta população endogâmica for formada pelo cruzamento entre duas linhagens, a freqüência dos dois alelos é a mesma e igual a 0,5 ( $p=q=0,5)$. Substituindo este valores na expressão (1) tem-se que a variância aditiva é igual a:

$$
V_{A}=0,5 a^{2}
$$

Considerando $n$ genes segregando, a variância genética aditiva desta população endogâmica torna-se:

$$
V_{A}=0,5 \sum^{n} a_{n}^{2}
$$

onde: $a_{n}$ é o componente aditivo do enésimo loco; $n$ é o número de locos segregando.

A variância genética total de uma população endogâmica é composta pela variância aditiva e pelas variâncias epistáticas do tipo aditivo $x$ aditivo e de maior ordem (Kearsey \& Pooni, 1996). Sabe-se que a variância aditiva geralmente apresenta valores muito mais altos do que a epistática (Pulcinelli et al., 1997). Se os efeitos aditivos dos $n$ locos não forem muito diferentes $\left(a_{i} \approx a_{2} \approx \ldots \approx a_{n}\right)$, a variância genética de uma população endogâmica é determinada, principalmente, pelo número de locos segregando.

Quando estimamos medidas de divergência entre genitores, acredita-se que o número de locos segregando e a variância genética sejam maiores em populações formadas a partir de genitores mais divergentes. Logo, pode-se utilizar a estimativa de divergência para tentar predizer o comportamento de populações, esperando que as mais promissoras sejam as obtidas a partir de cruzamentos entre genitores com maior divergência (Moser \& Lee, 1994; Manjarrez-Sandoval et al., 1997b; Helms et al., 1997)

O papel da média na determinação do potencial das populações aumenta à medida que as populações apresentam médias mais diferentes (Thorne \& Fehr, 1970). Quando as diferenças são expressivas, a variância genética deixa de ser o parâmetro mais importante. Uma das razões para que a média se tome mais importante que a 
variância é a utilização de linhagens com características diferentes das encontradas em cultivares.

Uma série de artigos publicados pelo grupo liderado pelo Dr. W.R. Fehr mostra que a inserção de genitores com características diferentes das presentes nos materiais cultivados (a partir de agora chamados de não adaptados) não produzem resultados satisfatórios caso se deseje obter cultivares diretamente de suas populações. Para melhor entendimento, estes artigos são sumariamente descritos a seguir.

Partindo da premissa que genótipos de soja não adaptados possuem genes que contribuem para o aumento da produção diferentes dos existentes no pool gênico das cultivares, Thome \& Fehr (1970) sintetizaram populações com níveis distintos de participação de linhagens não adaptadas. Eles verificaram que as médias e as variâncias genéticas das populações foram mais baixas e independentes, respectivamente, da porcentagem de participação de genitores não adaptados na genealogia.

Schoener \& Fehr (1979) investigaram com maior profundidade o efeito da porcentagem de genótipos não adaptados no desempenho de populações de soja. Eles utilizaram populações com 0\%, 25\%, 50\%, 75\% e 100\% de participação de linhagens não adaptadas e verificaram que as populações formadas exclusivamente a partir de genótipos adaptados foram sempre melhores. Mas, sugerem que populações com $50 \%$ de participação de genitores não adaptados podem garantir maiores ganhos a longo prazo em programas de seleção recorrente.

Considerando que a base genética das populações formadas por Schoener \& Fehr (1979) não era suficientemente ampla, Vello et al. (1984) sintetizaram populações com as mesmas percentagens de participação de genitores não adaptados, mas formadas a partir de um maior número de genótipos. Eles também verificaram que as populações com genótipos não adaptados na genealogia apresentaram reduzido potencial para o melhoramento em função da média baixa. Os autores consideraram que os ganhos com seleção obtidos nestas populações deveriam ser mais altos do que os obtidos nas populações formadas a partir de genótipos adaptados devido à presença de maior variância genética e que isto talvez compense as menores médias.

As mesmas populações sintetizadas por Vello et al. (1984) foram utilizadas por Ininda et al. (1996). Eles verificaram que as populações sem a participação de genitores não adaptados continuavam a apresentar maior potencial para o 
melhoramento, mesmo após três ciclos de seleção recorrente. Também verificaram que as taxas de ganho por ciclo de seleção foram semelhantes em quase todas as populações. Eles atribuíram estes resultados a sub-avaliação da variância genética da população formada apenas por genitores adaptados no ano em que foi realizado o ciclo 0 e a diminuição da variância genética após as seleções nas populações onde linhagens não adaptadas foram utilizadas.

Como se percebe, a utilização de genitores não adaptados não se justifica quando se deseja obter novas cultivares de soja, pois reduzem de modo indesejado a média dos caracteres. Portanto, as predições que visem maximizar a variância genética não seriam úteis.

Contudo, os genitores não adaptados são amplamente utilizados como fonte de variabilidade em caracteres que as cultivares não apresentam desempenho satisfatório (Schoener \& Fehr, 1979). Quando se deseja melhorar o desempenho de uma cultivar já existente, o programa se baseia em retrocruzamentos. Entretanto, se mais de um gene deve ser transferido ou se deseja aumentar a variabilidade de um caráter quantitativo específico, como teor de proteína em soja, os retrocruzamentos podem ser pouco eficientes ou muito laboriosos (Fehr, 1987). Nestes casos, costuma-se realizar cruzamentos para gerar linhagens que serão posteriormente utilizadas como genitoras em programas de melhoramento.

Nos retrocruzamentos, um dos fatores que determina o número de gerações necessárias para a recuperação do genótipo recorrente é a semelhança entre os genitores recorrente e doador. Isto ocorre de tal modo que se o doador é muito inferior ao genitor recorrente é necessário um número maior de gerações de retrocruzamentos para reestabeler as médias do recorrente (Fehr, 1987). Portanto, quanto mais semelhantes forem os genitores mais rápido e efetivo será o programa.

Nos casos em que a utilização de genitores não adaptados é realizada pela hibridação seguida de seleção, a utilização de genótipos não adaptados com grandes diferenças aos adaptados deve gerar populações com grandes alterações indesejadas na média de caracteres quantitativos importantes (Fehr, 1987). As alterações devem ser maiores quanto os genitores adaptados e não adaptados foram bastante diferentes. Caso se disponha de um conjunto de linhagens não adaptadas que possuam as qualidades necessárias para serem utilizadas, as que forem mais semelhantes aos genótipos adaptados devem ser preferidas. Se a escolha da linhagem não adaptada se 
basear em estimativas de divergência genética, aquelas que apresentarem as menores divergências em relação a um grupo de linhagens adaptadas devem resultar em populações mais promissoras (Abdelnoor et al., 1995).

\subsection{Predição do potencial de populações}

\subsubsection{Predição com base na genealogia dos genitores}

A predição do comportamento de populações baseada na genealogia dos genitores geralmente é realizada empregando o coeficiente de parentesco de Malécot (1948) ou medidas desenvolvidas a partir dele. Este coeficiente expressa a probabilidade de dois individuos apresentarem um alelo idêntico por descendência em um loco tomado ao acaso. Espera-se que quanto menor o coeficiente de parentesco entre dois indivíduos, maior seja o número de locos segregando. Desta maneira a escolha de genitores com coeficientes de parentesco mais baixo deve maximizar a variância genética e, em conseqüência, aumentar a probabilidade de detecção de segregantes transgressivos.

O coeficiente de parentesco pressupõe que os ancestrais originais não são aparentados, que a contribuição de cada um dos genitores é a mesma e que os descendentes foram formados na ausência de seleção (natural ou artificial), mutação, migração e deriva. A acurácia do coeficiente de parentesco depende da disponibilidade de genealogias detalhadas e precisas. Quando as informações estão ausentes ou são imprecisas, as predições são muito prejudicadas ou não são efetivas (Messmer et al., 1993).

A seguir serão descritos alguns trabalhos que tentaram associar o coeficiente de parentesco a parâmetros importantes ao melhoramento de algumas espécies autógamas ou parcialmente autógamas.

Cowen \& Frey (1987a) trabalhando com 28 cruzamentos realizados entre oito linhagens de aveia (Avena sativa L.) verificaram que a transformação de Jaccard do coeficiente de parentesco $\left(J_{C P}=\left[e^{(1-C P)}\right]-1\right)$ apresentou correlações negativas com a 
heterose, correlações positivas com o número de segregantes transgressivos em parte dos caracteres e correlações positivas com o logaritmo da variância genética generalizada. Contudo, quase todos os coeficientes de correlação significativos observados pelos autores foram baixos.

Souza \& Sorrells (1991) obtiveram correlações significativas, mas baixas, entre a transformação de Jaccard da distância genealógica e a variância genética de seis caracteres em populações de aveia.

Moser \& Lee (1994) não encontraram correlações entre a transformação de Jaccard do coeficiente de parentesco e a heterose em aveia, mas verificaram correlações positivas com a variância genética de três caracteres e com a variância generalizada. Novamente, as correlações significativas não foram altas.

Em trigo, Cox \& Murphy (1990) não obtiveram correlações significativas entre a heterose estimada em $F_{2}$ e a distância genealógica (DG=1-CP). Contudo, os cruzamentos sem relações de parentesco apresentaram, em média, maior heterose do que os cruzamentos onde os genitores apresentavam ancestrais comuns.

Barbosa-Neto et al. (1996) avaliaram populações de trigo por quatro anos e verificaram que o coeficiente de parentesco apresentou correlações muito baixas com a heterose de alguns caracteres. As correlações observadas dependeram do ano em que as estimativas da heterose foram obtidas. Os autores concluíram que o coeficiente de parentesco não teria capacidade de predizer o comportamento das populações estudadas. A mesma conclusão foi obtida por Picard et al. (1992), que não conseguiram predizer a heterose de 47 híbridos de trigo utilizando o coeficiente de parentesco.

Fabrizius et al. (1998) verificaram que uma porção negligenciável da heterose em populações $F_{2}$ de trigo é explicada pela distância genealógica. Também observaram que as populações com nenhuma ou com pouca relação genealógica apresentam, em média, maior heterose. Porém, as populações com as maiores heterose não eram, necessariamente, não aparentadas. Os autores salientaram que o pequeno número de populações utilizadas não permitiu conclusões generalizadas.

Burkhamer et al. (1998) verificaram que o coeficiente de parentesco apresentou correlações significativas com a variância genética e o número de segregantes transgressivos em alguns caracteres de trigo. Como as correlações foram baixas ou 
nulas, os autores concluiram que o coeficiente de parentesco não foi um bom preditor do comportamento das populações, para as características estudadas.

Trabalhando com Brassica napus L., Lefort-Buson et al. (1987) observaram que a heterose e a performance de hibridos $F_{1}$ aumentam com a distância genealógica. Segundo os autores, quando as relações entre a heterose e o coeficiente de parentesco foram analisadas mais detalhadamente, os resultados foram inconsistentes. A falta de homogeneidade nos experimentos realizados e a ausência parcial de algumas pressuposições do coeficiente de parentesco foram atribuidas como as causas da inconsistência verificada. Os autores sugerem que outros tipos de estimativas da divergência podem ser associadas ao coeficiente de parentesco para melhorar as relações entre a distância genética e a heterose em $B$. napus.

Manjarrez-Sandoval et al. (1997a) testaram o coeficiente de parentesco para predizer o comportamento da heterose em três conjuntos de populações $F_{2}$ de soja avaliadas em dois locais. Cada conjunto era formado por oito populações originadas do cruzamento entre um testador e oito linhagens. O coeficiente de parentesco foi capaz de predizer a heterose para: produção de grãos dos dois conjuntos de populações em um local, peso médio de 100 grãos em todos os conjuntos de populações nos dois locais e altura das plantas em dois conjuntos de populações nos dois locais. Os coeficientes de regressão obtidos foram relativamente altos e a menor capacidade do coeficiente de parentesco em predizer a heterose da produção de grãos foi atribuida à herdabilidade mais baixa deste caráter. Na opinião dos autores, a limitada capacidade preditiva do coeficiente de parentesco impede sua utilização como único critério para a seleção de genitores visando obter populações com alta heterose.

Os mesmos autores (Manjarrez-Sandoval et al., 1997b) verificaram que o coeficiente de parentesco mostrou alta relação linear com a variância genética da produção de grãos, sendo tanto maior a variância quanto menor o grau de parentesco entre os genitores. Relações bi-segmentadas e polinomiais foram obtidas e explicaram $97 \%$ e $51 \%$ da variância genética, respectivamente. Segundo os autores, as altas correlações verificadas entre a variância genética e o coeficiente de parentesco mostram que as pressuposições do coeficiente de parentesco (igual contribuição dos pais e ausência de relação entre os genitores ancestrais) são válidas para soja.

Kisha et al. (1997) avaliaram a distância genealógica como medida preditiva do comportamento da variância genética para os caracteres produção de grãos, altura das 
plantas e dias para maturação em três conjuntos de populações endogâmicas e parcialmente endogâmicas de soja. Eles observaram correlações significativas entre a distância genealógica e a variância genética da altura das plantas no primeiro conjunto e da variância genética da altura das plantas e do número de dias para maturação no terceiro conjunto. A divisão das populações de acordo com a distância genealógica mostrou que as populações cujos genitores eram mais aparentados tenderam a apresentar menor variância genética do que as populações formadas a partir de genitores com menores relações de parentesco. Os autores concluíram que, embora o coeficiente de parentesco não tenha permitido a obtenção de predições acuradas da variância genética das populações, ele pode ser usado para identificar grupos de cruzamentos que, em média, produzem populações com maior variância genética.

Os coeficientes de parentesco entre os genitores de seis populações $F_{3: 4}$ de soja não foram apropriados para predizer a variância genética de quatro caracteres (Helms et al., 1997). Os autores explicam que a ausência de correlações pode ter ocorrido em função do coeficiente de parentesco medir apenas o grau de similaridade por descendência, enquanto a variância genética é uma medida do grau de similaridade em estado, ou seja, toda a similaridade existente entre dois individuos. Eles também atribuem os resultados à possibilidade das informações genealógicas serem incorretas. Contudo, a divisão das seis populações em dois grupos de acordo com o coeficiente de parentesco forneceu variâncias genéticas médias maiores para as populações formadas a partir do cruzamento de genitores não aparentados. Na opinião dos autores estes resultados sugerem que, embora o coeficiente de parentesco não possa predizer a magnitude da variância genética, cruzamentos entre genitores não aparentados produzirão, em média, populações com maior variância genética do que populações entre genitores aparentados.

Como se verifica pelos artigos descritos, o coeficiente de parentesco apresenta pouca capacidade para predizer o comportamento da heterose e da variância genética das populações. Parte da incapacidade preditiva pode ter origem nas pressuposições assumidas pelo coeficiente de parentesco (MacCluer et al., 1983; Lefort-Buson et al., 1987; Picard et. al., 1992; Moser \& Lee, 1994; Abdelnoor et al., 1995) e na falta de precisão das anotações genealógicas existentes (Lefort-Buson et al., 1987, Picard et. al., 1992; Messmer et al., 1993; Helms et al., 1997). Outro fator que pode estar associado ao desempenho não satisfatório do coeficiente de parentesco como preditor 
é a utilização de estimativas pouco consistentes dos parâmetros populacionais (Kisha et al., 1997; Fabrizius et al.,1998).

Com relação à soja, alguns resultados experimentais indicam que a contribuição genômica dos pais é a mesma, ainda que sob seleção (VanToai et al., 1998; Manjarrez-Sandoval et al., 1997b) e que os ancestrais remotos são não correlacionados (Gizlice et al., 1993a). Contudo, outros autores sugerem que os pressupostos podem não ser verdadeiros (Ininda et al., 1996; Prabhu et al., 1997). A veracidade das pressuposições do coeficiente de parentesco em soja permanece sem uma resposta definitiva.

2.2.2 Predição com base em estimativas de distância genética obtidas a partir de marcadores morfológicos e/ou caracteres quantitativos

As estimativas de distância genética baseadas em características morfológicas e quantitativas, junto com o coeficiente de parentesco, são estimativas clássicas de diversidade genética. Elas já foram utilizadas em quase todas as espécies vegetais cultivadas e em parte das espécies silvestres. Poucos devem ser os programas de melhoramento que, ao menos em seu início, não tenham utilizado estes estimadores de divergência na tentativa de predizer as melhores populações ou híbridos.

Em pimentão, Miranda et al. (1988) verificaram que a distância de Mahalanobis apresentou correlação significativa, mas baixa, com a heterose para produção de frutos. Em trabalho mais recente, Oliveira et al. (1998) verificaram que a heterose e a capacidade específica de combinação do caráter peso da matéria seca de híbridos de pimentão apresentaram correlações significativas com a distância de Mahalanobis, estimada a partir de oito características quantitativas. Os autores concluíram que a seleção de genitores de pimentão para a obtenção de híbridos com base na distância de Mahalanobis apresentaria nível de confiabilidade aceitável.

Em tomate a distância $D^{2}$ de Mahalanobis e a distância euclidiana apresentaram correlações altas com a heterose para produção (Maluf et al., 1983). Os autores concluíram que ambas as estimativas de diversidade podem ser utilizadas para 
reduzir o número de cruzamentos a serem realizados em programas de melhoramento de tomate, principalmente em seus estágios iniciais.

Lefort-Buson et al. (1986) verificaram que a distância $D^{2}$ de Mahalanobis foi adequada para predizer a heterose de hibridos $F_{1}$ de canola (Brassica napus L.) nos caracteres altura das plantas e a média da altura das plantas. Correlações múltiplas envolvendo três diferentes estimativas de diversidade $\left(D^{2}\right.$, distância genealógica e a capacidade de combinação dos genitores) forneceram maiores informações a respeito do comportamento da heterose e da performance dos híbridos $F_{1}$. Os autores concluíram que a utilização simultânea dos estimadores de diversidade genética apresentou resultados mais satisfatórios.

A distância euclidiana entre seis genótipos de canola, calculada a partir de caracteres morfológicos e quantitativos, apresentou correlações significativas com a heterose para o número de vagens por planta, número de sementes por vagem e produção (Ali et al., 1995).

A distância genética de Nei, obtida pela análise de características morfológicas, e a distância euclidiana, com base em caracteres quantitativos, apresentaram correlações significativas com o desempenho de hibridos $F_{1}$ de ervilha em parte dos caracteres avaliados (Sarawat et al., 1994b). Também foram verificadas algumas correlações entre a distância euclidiana e a variância de populações $F_{5}$. Comparando as estimativas de distância genética realizadas, a que apresentou melhor desempenho foi a distância euclidiana.

Cox \& Murphy (1990) obtiveram seis estimativas de divergência genética entre linhagens de trigo com base em caracteres quantitativos. Eles verificaram que estas estimativas estavam pouco ou não correlacionadas com a heterose dos caracteres produção, peso e número de grãos. Os autores sugeriram a realização de uma seleção de genitores para maximizar a heterose em três estágios: no primeiro seriam selecionadas as linhagens com maior performance per se; no segundo, os materiais remanescentes seriam melhor avaliados e aqueles que apresentaram a maior distância genética calculada com base em caracteres quantitativos seriam submetidos ao terceiro estágio, no qual seriam eleitas as linhagens que apresentassem maior distância genealógica.

Cowen \& Frey (1987b) testaram três estimativas de distância genética obtidas a partir da avaliação de caracteres quantitativos em linhagens de aveia: distância 
euclidiana, calculada a partir dos cinco primeiros componentes principais, distância de Hanson e Casas e a distância de Cervantes. Eles obtiveram correlações baixas mas significativas com o número de segregantes transgressivos em parte dos caracteres avaliados.

A separação de genitores de populações de amendoim (Arachis hypogea L.) em quatro grupos de acordo com sua divergência genética, medida pela distância $D^{2}$, mostrou que há um nivel ótimo de divergência genética entre genitores para se obter heterose, acima ou abaixo do qual as heteroses tendem a diminuir (Arunachalam et al., 1984) . Este nivel ótimo seria encontrado entre genitores com niveis intermediários de divergência.

Gumber et al. (1999) utilizaram diversas características quantitativas e morfológicas de Vicia faba L. para estimar a distância $D^{2}$ de Mahalanobis. A distância foi utilizada para tentar predizer a variância genética de caracteres quantitativos de populações $F_{2: 4}$, mas nenhuma correlação significativa foi observada.

Correlações significativas e relativamente altas foram obtidas entre a heterose (da produção de grãos e de alguns componentes da produção) de populações $F_{2}$ de feijão (Phaseolus vulgaris L.) e a distância $D^{2}$ de Mahalanobis (Ghaderi et al., 1984). Este mesmo trabalho relata correlações significativas entre a heterose em $F_{1}$ e $F_{2}$ em alguns caracteres de Vicia faba var equina. As correlações verificadas com $V$. faba, em sua maioria, foram negativas.

Em grão-de-bico, a distância $D^{2}$ de Mahalanobis, a análise fatorial e as variáveis canônicas foram utilizadas para determinar quais das 132 linhagens avaliadas deveriam ser os melhores genitores em programas de melhoramento (Khan et al., 1991). Os autores concluíram que todas as técnicas foram inadequadas para predizer com acurácia os melhores genitores.

Gizlice et al. (1993b) estimaram a similaridade genética entre cinco genitores ancestrais das cultivares de soja dos EUA. A similaridade foi obtida pela expressão: $S_{y}=1-\left(D_{y} / D_{\max }\right)$, onde $D_{y}$ é a distância genética obtida pela análise dos componentes principais e de seus autovetores, obtidos a partir da análise de 10 caracteres quantitativos. Foi verificado que a similaridade genética estava correlacionada com a heterose para produção de grãos. 


\subsubsection{Predição com base na avaliação em gerações precoces}

Jinks \& Pooni (1976) desenvolveram uma expressão para predizer a probabilidade de uma determinada linhagem oriunda de uma população endogâmica obtida por SSD (single seed descent) apresentar comportamento superior ou inferior a determinado padrão fenotípico:

$$
P S=\frac{[d]}{\sqrt{D+E}}
$$

Na expressão, $d$ é o desvio em relação à média dos pais; $D$ é a variância genética aditiva; $E$ é a variância ambiental.

A predição considera que a média das linhagens de uma população é igual à média dos pais. Jinks \& Pooni (1976) ressaltaram a necessidade de boas estimativas da variância genética aditiva e do conhecimento da magnitude dos efeitos epistáticos, sendo portanto necessário empregar delineamentos genéticos adequados. Três delineamentos genéticos foram testados para estimar estes componentes em populações de Nicotiana rustica: Triple Test Cross em $\mathrm{F}_{2} ; \mathrm{F}_{2}$ e retrocruzamentos e Triple Test Cross em retrocruzamentos. Os autores concluiram que não é necessário avançar uma população para $\mathrm{F}_{3}$ sem antes conhecer seu potencial.

Jinks \& Pooni (1980) utilizaram as mesmas expressões para realizar predições a respeito de populações endogâmicas. Contudo, os autores empregaram famílias $F_{3}$ e consideraram despreziveis os efeitos de dominância. Assim, foi considerado que a variância genética verificada em $\mathrm{F}_{3}$ é devida exclusivamente a fatores aditivos. Foi observado que as estimativas da variância aditiva obtidas em familias $F_{3}$ e por Triple Test Cross não diferiam das verificadas na geração $F_{7}$. A possibilidade de utilização de famílias $F_{3}$ ao invés de um conjunto de populações para estimar a variância aditiva representa uma grande economia de esforços.

Toledo (1987) testou o método proposto por Jinks \& Pooni (1980) em soja. Segundo o autor, os resultados confirmam a utilidade da metodologia, permitindo que 0 melhorista tenha acesso mais cedo a informações sobre o potencial das populações e possa tomar decisões importantes para o programa de melhoramento. Triller \& Toledo (1996) verificaram que a utilidade da metodologia em soja independe da herdabilidade e da complexidade do controle genético do caráter, mas não da presença da interação 
entre genótipos e ambientes. Quando a interação está presente, os autores recomendaram a utilização de mais de uma população de referência e a avaliação em mais de um ambiente.

As estimativas da capacidade geral de combinação obtidas a partir de cruzamentos dialélicos são rotineiramente utilizadas para realizar predições em espécies alógamas. Embora também venham sendo usadas em espécies autógamas, o número de trabalhos é muito menor, indicando que poucos têm utilizado este método para realizar predições. Contudo, algumas publicações mostram que este método pode ser bastante eficaz na predição do comportamento de populações endogâmicas.

Pulcinelli (1997) verificou correlações altas entre as estimativas dos efeitos da capacidade geral obtidas em avaliações de populações de soja na geração $F_{2}$ e $F_{2: n}$. Segundo o autor, a seleção dos genitores com base na capacidade geral de combinação da geração $F_{2}$ pode ser um indicador seguro do potencial das populações endogâmicas.

Resultado semelhante foi obtido por Sarawate et al. (1994a), que verificaram que a média de três caracteres (em oito avaliados) de populações $F_{5}$ de ervilha apresentavam correlações com a capacidade geral de combinação na geração $F_{1}$. Os autores também observaram que as médias das populações $F_{5}$ foram correlacionadas com a heterose e com a média dos genitores, sendo a magnitude dos coeficientes bastante semelhante.

Ramalho et al. (1988) realizaram um dialelo parcial utilizando quatro cultivares adaptadas de feijão à região sul de Minas Gerais e cinco outras linhagens introduzidas. Este dialelo parcial foi avaliado nas gerações $F_{2}, F_{3}$ e $F_{4}$. Eles não verificaram interação significativa entre genótipos e gerações, o que os levou a concluir que a capacidade geral de combinação não interagiu com a geração utilizada. Com base na maior capacidade de combinação verificada nos dois grupos de linhagens eles elegeram uma população como a mais promissora para seleção.

Quando os cruzamentos dialélicos são avaliados em gerações com endogamia incompleta, para que a capacidade geral de combinação possa ser utilizada para predizer o comportamento de populações endogâmicas é necessário que: i) que não haja interação entre a capacidade geral com gerações (Ramalho et al., 1988). ii) as magnitudes dos efeitos epistáticos do tipo aditivo $x$ aditivo e de ordens superiores não 
sejam suficientes para alterar a classificação das populações realizada pela capacidade geral de combinação (Stuthman \& Stucker, 1975; Freire Filho, 1988).

Freire Filho (1988) realizou um cruzamento dialélico entre 10 linhagens precoces de soja e avaliou as populações formadas na geração $F_{2}$. Os 10 caracteres avaliados apresentaram efeitos aditivos mais importantes do que os efeitos de dominância. Resultado semelhante foi obtido por Nass (1989), que avaliou um dialelo em $F_{2}$ para verificar o potencial de genótipos de soja para o cultivo de inverno. $O$ autor verificou que apenas os efeitos da capacidade geral de combinação foram significativos, indicando a maior importância dos efeitos aditivos e, possivelmente, epistáticos tipo aditivo $\times$ aditivo. Boa parte dos trabalhos publicados envolvendo cruzamentos dialélicos em gerações com baixo nível de endogamia em soja verificaram que os efeitos aditivos foram mais importantes para a composição do fenótipo, independente do tipo de análise dialélica utilizada (Paludzyszyn Filho, 1982; Cruz et al., 1987; Pimentel, 1991; Spehar, 1995).

\subsubsection{Predição com base na média dos genitores}

A média dos genitores é o principal método utilizado pelos melhoristas de espécies autógamas e de reprodução vegetativa na escolha dos genitores. Embora seja muito utilizado, poucas publicações recentes estão disponíveis, provavelmente devido a comprovada eficiência deste método.

A escolha de acordo com o comportamento per se é utilizada, principalmente, para maximizar a média das populações e tem por base o modelo aditivo-dominante, cujas expressões foram já foram apresentadas no item 2.1. Cabe ressaltar que as predições da média de populações serão mais efetivas quando o nivel de endogamia é mais alto, os efeitos epistáticos são pequenos e os locos que atuam no caráter estão segregando de modo independente. 
A seguir serão descritos trabalhos realizados para predizer parâmetros em populações através do comportamento per se dos genitores.

Em trigo, Bush et al. (1974) verificaram que a média dos genitores foi capaz de predizer a média da produção de grãos de 25 populações $F_{4}$ e $F_{5}$, bem como a média das cinco linhagens mais produtivas de cada população. Fabrizius et al. (1998) obtiveram altas correlações entre a média das linhagens genitoras e a média de seis populações nas gerações $F_{2}, F_{3}, F_{4}$ e $F_{4: 5}$. O nivel de endogamia interferiu no valor dos coeficientes de correlação, havendo um ligeiro aumento de sua magnitude com o aumento da endogamia. Os autores concluíram que o modelo aditivo explica adequadamente o comportamento das populações.

Em aveia, dois trabalhos relataram que a média dos pais não pode ser diferenciada da média de seus descendentes. O primeiro, realizado por Cowen \& Frey (1987a), verificou que a altura média das plantas em progênies $F_{2}$ foi semelhante à média dos genitores. No segundo (Souza \& Sorrels,1991), a igualdade entre a média dos genitores e de seus descendentes foi verificada para três caracteres (produção de grãos, biomassa e peso dos grãos) em 20 populações $F_{4}$.

Em feijão, a média dos genitores predisse a média de alguns componentes de produção e da produção de grãos em populações $F_{2}$ (Antunes et al.,1998) e em gerações com endogamia mais elevada (Hamblin \& Evans, 1976). Segundo Hamblin \& Rosielle (1978) a predição será mais precisa se os genitores forem avaliados em condições ambientais semelhantes às existentes onde as populações serão selecionadas.

Gumber et al. (1999) relataram que a média dos pais predisse o comportamento da média de populações $F_{2: 4}$ de Vicia faba $L$. com relação aos caracteres produção de grãos, dias para a antese, altura das plantas e número de sementes por plantas. Os autores também verificaram que a diferença absoluta entre a média dos pais $\left(\left|P_{1}-P_{2}\right|\right)$ não foi um bom preditor da variância genética de nenhum dos caracteres estudados. Em contrapartida, a diferença entre a média dos pais apresentou altas correlações com a variância genética de parte dos caracteres de ervilha avaliados por Sarawate et al. (1994a).

Em soja, Thorne \& Fehr (1970) verificaram que a média de populações formadas a partir do cruzamento entre linhagens adaptadas e não adaptadas foi diferente da média dos genitores, indicando a presença de efeitos epistáticos. 
Contudo, a classificação das populações condisse com o desempenho dos genitores per se, indicando que os efeitos aditivos foram mais importantes.

Kisha et al. (1997) encontraram uma correlação forte e positiva entre a média dos genitores e a média das cinco linhagens mais produtivas de populações de soja. A média do genitor mais produtivo também apresentou correlações significativas com o mesmo grupo de linhagens de cada população. Estes resultados foram obtidos para dois conjuntos de populações independentes.

\subsubsection{Predição com base em distâncias genéticas estimadas a partir de marcadores moleculares.}

As estimativas de diversidade genética obtidas pela análise das informações fornecidas por marcadores moleculares são as mais freqüentes na literatura atual. Elas têm sido obtidas por diferentes tipos de marcadores moleculares e analisadas por uma grande quantidade de metodologias. A utilização destas estimativas de diversidade diretamente em programas de melhoramento ainda não foi relatada. Contudo, diversos estudos foram realizados para verificar se é possivel realizar predições, principalmente a respeito da variância genética e da heterose.

Liu et al. (1999) observaram que a heterose e a performance de hibridos de trigo não apresentavam correlações com a distância genética baseada em marcadores RAPD. Contudo, os clusters formados pela análise de agrupamento das distâncias genéticas separaram as linhagens genitoras em grupos de acordo com sua performance com relação aos componentes da produção de grãos.

As distâncias genéticas entre dez linhagens endogâmicas das subespécies indica e japonica de Oryza sativa L. foram calculadas utilizando os marcadores RAPD e microssatélites conjuntamente (Xiao et al., 1996). Estas distâncias foram comparadas com o desempenho e a heterose de 43 das 45 combinações híbridas possiveis entre as dez linhagens. As correlações observadas entre a distância genética com o desempenho dos híbridos e com a heterose foram altas e positivas para parte dos caracteres estudados. Quando as populações foram subdivididas em 
três conjuntos de acordo com a subespécie dos genitores, as correlações com a performance e a heterose da produção de grãos foram significativas para as populações formadas pelo cruzamento entre genitores da mesma subespécie, mas não para as populações oriundas de cruzamentos entre subespécies. Segundo os autores, estes resultados indicam que a distância genética obtida pela análise dos dois marcadores pode ser útil apenas para populações intra-subespecificas, ou seja, aquelas formadas pelo cruzamento entre duas linhagens de uma mesma subespécie.

Sant et al. (1999) não detectaram relações lineares entre a distância genética de oito linhagens de grão-de-bico, estimada pela análise de marcadores RAPD e microssatélites, e a heterose dos 28 hibridos obtidos pelo intercruzamento das linhagens. Contudo, as maiores heteroses foram observadas nos hibridos formados pelo cruzamento entre linhagens pertencentes a grupos diferentes do dendrograma, obtido pela análise de agrupamento das distâncias genéticas.

Duarte et al. (1999) observaram que a heterose e a capacidade especifica de combinação de populações $\mathrm{F}_{4}$ de feijoeiro, não foram correlacionadas com a distância genética baseada em marcadores RAPD. Segundo os autores, a correlação é uma estimativa que demanda variabilidade nos dois parâmetros envolvidos, o que não foi verificado para heterose e a capacidade especifica de combinação, provavelmente, devido a análise ter sido realizada em $\mathrm{F}_{4}$.

Burkhamer et al. (1998) verificaram que as distância genéticas estimadas a partir dos marcadores AFLP (Amplified Fragment Length Polymorphism) e STS-PCR (Sequence Tagged Sites) não foram bons preditores da variância genética e do número de segregantes transgressivos. Estes resultados foram obtidos em nove caracteres avaliados em 12 populações $F_{3: 5}$ de trigo. A combinação das distâncias genéticas obtidas pelos dois tipos de marcadores não resultou em aumento da capacidade preditiva.

Foi verificado que as variâncias genéticas de seis caracteres de 28 populações de aveia não puderam ser preditas pela distância genética de seus genitores, calculadas a partir de marcadores RFLP (Restriction Fragment Length Polymorphism) (Moser \& Lee, 1994). De modo geral, a variância foi independente ou muito pouco correlacionada com a distância genética, mesmo quando distâncias genéticas baseadas nos marcadores, no grau de parentesco dos genitores e no desempenho dos genitores em caracteres quantitativos foram utilizadas simultaneamente. 
Paz \& Veilleux (1997) verificaram que a distância genética entre individuos duplo haplóides de Solanum phurela (Juz. \& Buk.), estimada por marcadores RAPD, não mostrou correlação com a produção de tubérculos. Porém, os descendentes de quatro genitores apresentaram uma tendência de aumento da produção com o aumento da distância genética.

A distância genética entre 20 linhagens de $V$. faba, estimadas por marcadores RAPD, não se mostrou correlacionada com a variância genética de quatro caracteres em populações $F_{3: 4}$ (Gumber et al., 1999)

Embora a obtenção de vigor híbrido não seja um dos objetivos dos atuais programas de melhoramento de soja, alguns trabalhos buscaram identificar se a heterose pode ser predita pelas distâncias genéticas baseadas em marcadores moleculares.

Manjarrez-Sandoval et al. (1997a) encontraram correlações significativas entre a distância genética estimada a partir de marcadores RFLP e a heterose dos caracteres peso de 100 sementes e altura das plantas em populações $F_{2}$ de soja. $A$ existência de correlação entre a heterose para a produção de grãos e a distância genética foi dependente do local e do ano em que as avaliações foram realizadas. Os autores concluíram que o valor preditivo da distância genética foi insuficiente para que possa ser utilizado em programas de melhoramento.

Cerna et al. (1997) realizaram uma seleção simulada para determinar quais combinações de genitores de híbridos $F_{1}$ de soja seriam escolhidos de acordo com: (i) a produção dos genitores, (ii) a origem geográfica das linhagens, (iii) as distâncias genéticas estimadas por marcadores isoenzimáticos e (iv) as distâncias genéticas baseadas em marcadores RFLP. Cada um dos critérios foi aplicado para um conjunto diferente de linhagens. Eles verificaram que as heteroses dos hibridos selecionados pela a distância genética baseada em RFLP apresentaram os menores valores (ou próximos aos menores) entre os quatro critérios testados. A seleção realizada segundo a divergência alélica dos marcadores isoenzimáticos foi a que apresentou os maiores valores de heterose. Os autores destacaramm que a confirmação da vantagem apresentada pelas estimativas de divergência baseadas em isoenzimas em relação às baseadas em RFLP requer que ambas sejam aplicadas a um mesmo conjunto de genótipos, o que não foi realizado. 
Outros trabalhos foram realizados em soja para verificar se a distância genética baseada em marcadores moleculares pode predizer o comportamento da variância genética.

Manjarrez-Sandoval et al. (1997b) observaram uma relação quadrática entre a distância genética baseada em marcadores RFLP e a variância genética da produção de grãos em populações endogâmicas de soja. Os autores concluíram que a distância genética pode ser utilizada pelos programas de melhoramento de soja, mas com cautela. A validade desta conclusão deve ser restrita, pois foi obtida pela análise de apenas seis populações.

Helms et al. (1997) não detectaram associações entre a distância genética estimada por marcadores RAPD e a variância genética de quatro caracteres em seis populações $F_{3: 4}$. Os autores sugeriram que a utilização de marcadores ligados a QTL's pode resultar em associações entre a distância genética e a magnitude da variância genética.

Kisha et al. (1997) realizaram um trabalho para verificar se a distância genética entre genitores, medida por marcadores RFLP, seria capaz de predizer a variância genética de três conjuntos de populações. Para um dos conjuntos foi verificado que a distância genética mostrou correlação significativa com a variância genética da altura das plantas. Coeficientes de correlação relativamente altos (próximos de 0,60) também foram obtidos com as estimativas de variância genética da produção de grãos e da altura das plantas na maturação em um ano da avaliação. Para o segundo conjunto, todas as variâncias genéticas foram independentes da distância genética. Para o terceiro conjunto, correlações significativas foram obtidas com a variância da altura das plantas e do número de dias para a maturação, dependendo do ano em que a avaliação foi conduzida. Foi verificado que as correlações com a variância da produção de grãos do terceiro conjunto foram muito influenciadas pelo comportamento de uma população, que apresentou variância muito superior ao que seria esperado segundo a distância genética. Quando esta população foi retirada da análise, as correlações passaram a ser significativas e altas. Os autores concluiram que a distância genética pode ser importante para identificar grupos de cruzamentos que podem produzir variâncias genéticas acima da média.

No mesmo trabalho (Kisha et al.,1997), foi verificada uma correlação alta e negativa entre a distância genética e a média das cinco progênies mais produtivas de 
cada uma das populações do segundo conjunto. Isto indica que quanto maior a distância genética entre os genitores, menor é a média das cinco progênies mais produtivas da população.

Como se pode perceber, nenhuma estimativa de diversidade foi capaz de predizer de modo consistente a variância genética das populações.

Gumber et al. (1999) apresentaram uma boa discussão a respeito da ausência de correlações entre as estimativas de diversidade e variância genética utilizando considerações biométricas interessantes. Supondo uma análise de correlação $r(X, Y)$ entre duas variáveis $X$ e $Y$, que só podem ser estimadas com algum resíduo, isto é, $\hat{X}=X+\varepsilon_{x}$ e $\hat{Y}=Y+\varepsilon_{y}$. Assumindo que $\varepsilon_{x}$ e $\varepsilon_{y}$ são independentes um do outro e também de $X$ e de $Y$, a correlação entre $\hat{X}$ e $\hat{Y}$ é igual a:

$$
r(\hat{X}, \hat{Y})=r(X, Y) h_{x}+h_{y}
$$

onde $h_{x}^{2}=\frac{\sigma_{x}^{2}}{\sigma_{\hat{X}}^{2}}$, e $h_{Y}^{2}=\frac{\sigma_{Y}^{2}}{\sigma_{\hat{Y}}^{2}}$ são as repetibilidades de $\hat{X}$ e $\hat{Y}$.

Deste modo, uma baixa correlação entre a variância genética e um preditor $(\hat{Y})$ pode ser atribuída às seguintes razões: 1) a variância genética estimada tem uma baixa repetibilidade devido ao seu alto erro padrão; 2) a estimativa de diversidade genética $(\hat{Y})$ possui um grande residuo elou viés em relação a real diversidade genética (Y); 3) a correlação entre a real variância genética e a real diversidade genética é baixa.

Pode-se reduzir o erro padrão das estimativas da variância genética realizando experimentos com parcelas de tamanho adequado à herdabilidade do caráter, com grande número de repetições e em diferentes locais e anos (Fehr, 1987). Também é necessário que um grande número de descendentes sejam avaliados para minimizar as alterações das freqüências gênicas pelo efeito da deriva (Gumber et al., 1999; Kisha et al.1997).

As estimativas de diversidade genética baseadas em marcadores moleculares podem apresentar residuos e/ou viés em função de problemas durante a obtenção dos 
marcadores. Entre estes problemas, estão incluidos os erros de leitura dos géis, a utilização de marcadores não consistentes e a incapacidade de separação de produtos de amplificação ou fragmentos de DNA com tamanho muito semelhantes (Gumber et al., 1999). Estes erros são maiores ou menores de acordo com a técnica utilizada e os cuidados tomados pelo pesquisador.

A distribuição dos marcadores pelo genoma depende da técnica utilizada, mas, dentro da região acessada pela técnica, espera-se que os marcadores estejam igualmente distribuídos. Contudo, as regiões acessadas pelo marcador podem não ter sido amostradas de mesmo modo, havendo regiões com maior concentração de marcadores do que outras. Isto pode acontecer em função do número insuficiente de marcadores utilizados, do acaso, dos tipos de seqüências preferencialmente detectadas pelo marcador ou de outro fator não identificado (Gumber et al., 1999), mas as conseqüências serão sempre as mesmas: erros nas estimativas da distância genética.

Correlações entre a variância genética e estimativas de distância só devem estar presentes se a distribuição dos marcadores pelo genoma for semelhante à dos QTL's (quantitative trait loci) que afetam o caráter. Parte dos locos amostrados pelos marcadores pode não estar ligada a QTL's que influenciam no caráter e parte dos QTL's pode não estar ligada a nenhum marcador (Bemardo, 1992). Também é provável que os diferentes QTL's que controlam um caráter apresentem efeitos diferentes e/ou que existam QTL's ligados, fazendo com que as regiões do genoma possuam diferentes pesos para a expressão do caráter. A distribuição dos marcadores pelo genoma depende da técnica utilizada, mas dentro da região acessada pela técnica, espera-se que a amostragem seja casualizada. Deste modo, quanto mais desigual for a distribuição dos QTL's pelo genoma e quanto maiores forem as diferenças na magnitude de seus efeitos sobre o caráter, menor deve ser a correlação entre a distância genética e a variância genética (Charcosset \& Essioux, 1994). 


\subsection{Partição da distância genética}

Melchinger et al. (1990b) propuseram que a distância genética fosse subdividida em dois componentes: um componente geral, denominado distância genética geral (DGG) e outro componente específico, denominado distância genética especifica (DGE). As estimativas destes dois novos parâmetros é realizada segundo o modelo I, método 4 da análise dialélica proposta por Griffing (1956). Segundo esta metodologia, cada distância genética é composta por:

$$
D G_{i j}=\overline{D G}+D G G_{i}+D G G_{j}+D G E_{i j}
$$

onde: $D G_{i j}$ é a distância genética entre os genótipos i e j; $\overline{D G}$ é a distância genética média; $D G G_{i}$ é a distância genética geral do genótipo i; $D G G_{j}$ é a distância genética geral do genótipo j; $D G E_{i j}$ é a distância genética específica entre os genótipos i e j.

As mesmas restrições impostas no dialelo convencional são válidas para este dialelo, ou seja, a soma das DGG deve ser igual a zero e a soma das $D G E_{i j}$, para todo j, também deve ser igual a zero.

Segundo os autores, valores elevados positivos ou negativos de DGG indicam que o genótipo possui muitos alelos que ocorrem em baixa ou alta freqüência, respectivamente. Valores elevados positivos ou negativos da DGE indicam que o cruzamento é mais heterozigoto ou menos heterozigoto, respectivamente, do que a média de todos os cruzamentos. É esperado que quanto maior a diferença entre o valor da DGG maior seja a diferença entre as médias dos genótipos. Quanto maior a DGE, maiores devem ser a variância genética e a heterose resultante do cruzamento entre os genótipos.

Os autores testaram a metodologia em quatro dialelos de milho (Melchinger et al.,1990b) e verificaram que as correlações da capacidade geral de combinação com a distância genética geral foram maiores do que as obtidas com a distância genética sem partição. Outro trabalho publicado pelos mesmos pesquisadores (Melchinger et al.,1990a), confirmou que a distância genética especifica apresenta maiores correlações com a capacidade especifica de combinação do que a distância genética. 
Outros estudos utilizaram a partição da distância genética para predizer parâmetros importantes para o melhoramento (Melchinger et al., 1992; Boppenmaier et al., 1993; Dhillon et al., 1993; Burstin et al., 1995; Ajmone-Marsan et al., 1998). Todos eles foram realizados em milho e mostraram que a partição da distância genética melhorọu a capacidade de realizar predições a respeito da heterose, capacidade específica de combinação e performance para a maioria dos caracteres avaliados. Estes resultados positivos foram obtidos independente do tipo de marcador e do tipo de distância genética utilizados. 


\section{MATERIAL E MÉTODOS}

3.1 Caracterização do ambiente de experimentação

A coleta dos dados e sintese das populações utilizadas neste trabalho foram realizados na área experimental do Departamento de Genética da Escola Superior de Agricultura "Luiz de Queiroz", Universidade de São Paulo. Esta área se situa no município de Piracicaba, Estado de São Paulo, a 22 $42^{\prime} 31^{\prime \prime}$ de latitude sul, $47^{\circ} 38^{\prime} 01^{\prime \prime}$ de longitude oeste, a 540 metros acima do nivel médio do mar.

\subsection{Material genético}

As populações endogâmicas de soja [Glycine max (L.) Merrill] foram formadas a partir do cruzamento dialélico de oito linhagens genitoras, excetuando-se os reciprocos. Todos os genitores utilizados na sintese destas populações apresentam um elevado teor de proteínas nos grãos e as populações formadas estão inseridas no programa de melhoramento visando aumentar o teor de proteínas nos grãos de soja, em desenvolvimento no Departamento de Genética da ESALQ-USP. Suas principais características foram descritas por Pimentel (1991) e são listadas a seguir:

1. Gaúcha: variedade brasileira, com hábito de crescimento indeterminado, flor branca, semente com tegumento amarelo, hilo e pubescência marrons. 
2. LA-4910-215: Linhagem proveniente de Louisiana (EUA), com hábito de crescimento indeterminado, flor roxa, semente com tegumento amarelo, hilo e pubescência cinzas.

3. OC-79230: Linhagem brasileira, com hábito de crescimento determinado, flor branca, semente com tegumento amarelo, hilo marrom e pubescência cinza.

4. BR-80-8858: Linhagem brasileira, com hábito de crescimento indeterminado, flor roxa, semente com tegumento amarelo, hilo e pubescência cinzas.

5. BR-80-14853: Linhagem brasileira, com hábito de crescimento indeterminado, flor roxa, semente com tegumento verde, hilo preto e pubescência marrom

6. PI-123439: Linhagem proveniente do banco de germoplasma americano e fornecida pela Embrapa Soja. Possui hábito de crescimento determinado, flor roxa, semente com tegumento amarelo, pubescência e hilo cinzas.

7. PI-165896: Linhagem proveniente do banco de germoplasma americano e fornecida pela Embrapa Soja. Possui hábito de crescimento determinado, flor roxa, semente com tegumento preto, pubescência marrom e hilo preto.

8. PI-239235: Linhagem proveniente do banco de germoplasma americano e fornecida pela Embrapa Soja. Possui hábito de crescimento indeterminado, flor branca, semente com tegumento amarelo, pubescência e hilo cinzas.

As linhagens genitoras 1 a 5 foram consideradas adaptadas, visto possuírem níveis de produção semelhante às cultivares atualmente utilizadas no Estado de São Paulo. Os genótipos 6 a 8 diferem das atuais cultivares com relação a características como porte e produção, portanto, eles foram considerados não adaptados. Buscou-se identificar a genealogia dos genótipos (Tabela 1), porém, para os genótipos Gaúcha, LA-4910-215 e OC-79230 não foi possivel obter a informação.

As oito linhagens foram cruzadas entre si e geraram 28 híbridos. Na geração $F_{2}$ foi constatado que uma das populações era proveniente de autofecundação e não de cruzamento e foi descartada. Posteriormente, mais duas populações se revelaram oriundas de autofecundações e também foram descartadas. Portanto, restaram 25 populações (Tabela 2). 
Tabela 1. Genealogia das linhagens genitoras

\begin{tabular}{|c|c|}
\hline Linhagem & Genealogia \\
\hline Gaúcha & Não identificada \\
\hline LA-4910-215 & Não identificada \\
\hline OC-79230 & Não identificada \\
\hline $\mathrm{BR}-80-8858^{1}$ & (D60-8107 ou D60-7965) x Abura \\
\hline BR-80-14853 ${ }^{1}$ & $($ Tracy $\times$ Abura $) \times\left(D 67-4823 \times \mathrm{R}^{*} 8^{\star}\right)$ \\
\hline $\mathrm{PI}-123439^{2}$ & Coletado em Myanmar em1937 \\
\hline $\mathrm{Pl}-165896^{2}$ & Coletado na Índia em 1948 \\
\hline $\mathrm{PI}-239235^{2}$ & Coletado na Tailândia em 1957 \\
\hline
\end{tabular}

Tabela 2. Populações avaliadas e seus respectivos genitores.

\begin{tabular}{|c|c|c|c|}
\hline População & Origem & População & Origem \\
\hline $1 \times 2$ & Gaúcha x LA-4910-215 & $3 \times 7$ & OC-79230 x PI-165896 \\
\hline $1 \times 3$ & Gaúcha x OC-79230 & $3 \times 8$ & OC-79230 x PI-239235 \\
\hline $1 \times 4$ & Gaúcha x BR-80-8858 & $4 \times 5$ & BR-80-8858 x BR-80-14853 \\
\hline $1 \times 6$ & Gaúcha x PI-123439 & $4 \times 6$ & BR-80-8858 x Pl-123439 \\
\hline $1 \times 7$ & Gaúcha x PI-165896 & $4 \times 7$ & BR-80-8858 x PI-165896 \\
\hline $1 \times 8$ & Gaúcha x PI-239235 & $4 \times 8$ & BR-80-8858 x PI-239235 \\
\hline $2 \times 3$ & LA-4910-215 x OC-79230 & $5 \times 6$ & BR-80-14853 x PI-123439 \\
\hline $2 \times 4$ & LA-4910-215 x BR-80-8858 & $5 \times 7$ & BR-80-14853 x Pl-165896 \\
\hline $2 \times 5$ & LA-4910-215 x BR-80-14853 & $5 \times 8$ & BR-80-14853 x PI-239235 \\
\hline $2 \times 6$ & LA-4910-215 x PI-123439 & $6 \times 7$ & $\mathrm{Pl}-123439 \times \mathrm{PI}-165896$ \\
\hline $2 \times 8$ & LA-4910-215 x PI-239235 & $6 \times 8$ & $\mathrm{PI}-123439 \times \mathrm{PI}-239235$ \\
\hline $3 \times 5$ & OC-79230 x BR-80-14853 & $7 \times 8$ & $\mathrm{PI}-165896 \times \mathrm{PI}-239235$ \\
\hline $3 \times 6$ & OC-79230 x PI-123439 & & \\
\hline
\end{tabular}


A partir da geração $F_{2: 3}$ cada população foi representada por um conjunto de vinte progênies provenientes de plantas $F_{2}$ diferentes. Cada progênie era representada por 30 plantas colhidas em bulk. A população $1 \times 4$ foi representada por apenas 13 progênies.

$O$ avanço das populações até a geração $F_{2: 8}$ foi realizado segundo o método da amostra dentro de progênies ou bulk dentro de progênies (Vello, 1985; Ramalho \& Vencovsky, 1978). Deste modo, em $F_{2: 8}$ cada população era representada por 20 progênies, sendo cada progênie composta por um conjunto heterogêneo de linhagens.

\subsection{Avaliação experimental das linhagens genitoras}

As linhagens genitoras foram avaliadas durante dois anos agricolas consecutivos, 1996/1997 e 1997/1998.

Os experimentos foram realizados utilizando o delineamento em blocos casualizados com dez repetições. Cada parcela foi constituida por quatro linhas de cinco metros, com espaçamento de 50 centimetros entre linhas. Procurou-se manter um estande de 15 plantas por metro. Considerou-se como parcela útil apenas as duas linhas centrais.

Os caracteres avaliados em 1996/1997 foram produção de grãos, altura das plantas na maturação, dias para a maturação, altura das plantas no florescimento e dias para o florescimento. Em 1997/1998, além dos caracteres avaliados no ano anterior, avaliou-se também o acamamento da parcela.

A produção de grãos foi medida em gramas produzidas pelas linhas centrais da parcela. A altura na maturação foi medida em centimetros do solo ao último internódio na maturação fisiológica das plantas e o caráter número de dias para a maturação foi medido como o periodo entre o plantio e a maturação fisiológica de $90 \%$ das plantas da parcela. A altura no florescimento e o número de dias para florescimento foram avaliados, respectivamente, como a distância em centimetros do solo ao último internódio e o periodo entre a germinação e o final do periodo vegetativo, respectivamente. Ambas as medidas foram tomadas quando $90 \%$ das plantas da parcela apresentavam as primeiras flores. As alturas na maturação e florescimento 
foram obtidas pela média de 20 plantas em cada parcela. $O$ acamamento foi quantificado por uma escala de notas, sendo atribuído valores entre 1 e 5 , que representam $0 \%$ e 100\% de plantas acamadas na parcela, respectivamente.

As análises de variância dos experimentos dos parentais foram realizadas segundo o delineamento em blocos casualizados. Quando o teste $F$ detectou diferenças significativas entre as médias dos genitores $(p \leq 0,05)$, aplicou-se o teste de Tukey.

3.4 Avaliação das populações endogâmicas ${ }^{1}$

As populações foram avaliadas em experimentos realizados em látice triplo nos anos agricolas de 1992/1993, 1993/1994, 1994/1995 e 1995/1996, que correspondem, respectivamente, às gerações $F_{2: 8}, F_{2: 9}, F_{2: 10}$ e $F_{2: 11}$. As 20 progênies de cada população foram alocadas hierarquicamente dentro da respectiva população. Utilizouse uma parcela de um metro de comprimento espaçada da vizinha por 50 centímetros. Procurou-se manter 17 plantas por parcela.

$\mathrm{Na}$ geração $\mathrm{F}_{2: 8}$ foram avaliados apenas os caracteres produção de grãos, altura na maturação e acamamento. $\mathrm{Na}$ geração $F_{2: 9}$ foram avaliados os caracteres produção de grãos, altura das plantas na maturação, altura das plantas no florescimento, dias para maturação, dias para florescimento e acamamento. $\mathrm{Na}$ geração $F_{2: 10}$ foram avaliados os caracteres produção de grãos, altura das plantas na maturação, altura das plantas no florescimento e dias para o florescimento. Em $F_{2: 11}$ foram avaliados os mesmos caracteres descritos em $F_{2: 10}$ além do número de dias para a maturação. Os critérios utilizados na avaliação foram idênticos aos descritos no item anterior, à exceção dos caracteres altura das plantas na maturação e altura das plantas no florescimento, nos quais foram avaliadas cinco plantas por parcela.

Dois tipos de análise de variância foram realizadas para analisar os experimentos das gerações $F_{2: n}$ : uma para comparar o comportamento das populações e outra para verificar o comportamento das progênies dentro de cada população.

${ }^{1}$ Análise previamente realizada por Pulcinelli (1997) para os caracteres produção de grãos e altura das plantas na maturação. As análises foram refeitas neste trabalho com nenhuma ou poucas alterações. 
A unidade experimental utilizada para comparar as populações $F_{2: n}$ foi a média das 20 progênies representantes de cada cruzamento. A análise foi realizada segundo o delineamento látice triplo.

As médias ajustadas das populações foram classificadas segundo o método de agrupamento desenvolvido por Scott e Knott (1974), utilizando o software MAPGEN. Este método se baseia em subdivisões sucessivas das populações segundo sua média até que a diferença entre dois subgrupos não seja significativa. O teste de significância entre subgrupos é realizado através da estatística $\lambda$ (teste da razão de verossimilhança). Maiores detalhes podem ser encontrados em Pacova (1992).

A análise conjunta dos experimentos considerando as populações $F_{2: n}$ foi realizada utilizando as médias ajustadas obtidas em cada ano. Foi empregada a média ponderada do erro efetivo como estimativa do quadrado médio do resíduo experimental (Silva, 1997).

O segundo tipo de análise de variância, efetuado para verificar 0 comportamento das progênies dentro de cada população, foi realizado segundo o delineamento hierárquico, com três repetições. A unidade experimental utilizada foi a média de cada uma das progênies. Esta análise foi utilizada para estimar as variâncias entre progênies $\left(\hat{\sigma}_{p}^{2}\right)$. As estimativas destes parâmetros genéticos foram obtidas pela esperança dos quadrados médios de cada fonte de variação, de acordo com a metodologia de Gaylor et al. (1970). O intervalo de confiança da variância de progênies dentro de população foi obtido de acordo com as expressões (Barbin, 1993):

$$
\frac{n_{t} \hat{\sigma}_{p}^{2}}{X_{n t ; 0.975}^{2}} \leq \sigma_{p}^{2} \leq \frac{n_{t} \hat{\sigma}_{p}^{2}}{X_{n t ; 0,025}^{2}}
$$

Os $n_{\mathfrak{t}}$ graus de liberdade são obtidos por:

$$
n_{t}=\frac{\left(Q M_{p}-Q M_{e}\right)^{2}}{\frac{\left(Q M_{p}\right)^{2}}{f_{p}}+\frac{\left(Q M_{e}\right)^{2}}{f_{e}}}
$$

onde: - $Q M_{p}$ é o quadrado médio de progênies;

- $Q M_{e}$ é o quadrado médio do resíduo;

- $f_{p}$ é o número de graus de liberdade associados a fonte de variação progênies;

- $f_{e}$ é o número de graus de liberdade associados a fonte de variação resíduo; 
- $X^{2}$ é a distribuição de qui- quadrado.

Para as análises conjuntas os $n_{\mathfrak{t}}$ graus de liberdade foram estimados por:

$$
n_{t}=\frac{\left(Q M_{p}-Q M_{p a}\right)^{2}}{\frac{\left(Q M_{p}\right)^{2}}{f_{p}}+\frac{\left(Q M_{p a}\right)^{2}}{f_{p a}}}
$$

onde: - $Q M_{p a}$ é o quadrado médio da interação entre progênies e anos;

- $f_{p a}$ é o número de graus de liberdade associados a interação progênies $x$ anos.

\subsection{Análise dialélica}

3.5.1 Dialelo incluindo as 25 populações ${ }^{1}$

As análises dialélicas para as 25 populações foram realizadas segundo o modelo I de Griffing, método 4 (Griffing, 1956):

$$
\bar{Y}_{i j .}=\mu+g_{i}+g_{j}+s_{i j}+\bar{e}_{i j}
$$

onde: $-\bar{Y}_{\mathrm{ij}}$ é a média de $k$ repetições da população formada pelo cruzamento entre o genitor i e o genitor $j$;

- $\mu$ é a média geral da tabela dialélica;

- $g_{i}$ é o efeito devido à capacidade geral de combinação do parental i;

- $\mathrm{g}_{\mathrm{j}}$ é o efeito devido à capacidade geral de combinação do parental j;

- $s_{i j}$ é o efeito da capacidade específica de combinação para a população formada pelo cruzamento entre os genitores i e j;

\footnotetext{
${ }^{1}$ Análise previamente realizada por Pulcinelli (1997) para os caracteres produção de grãos e altura das plantas na maturação. As análises foram refeitas neste trabalho com nenhuma ou poucas alterações.
} 
- $\overline{\mathrm{e}}_{\mathrm{ij} \text {. }}$ é o erro médio obtido da análise de variância segundo o delineamento látice, dividindo-se o erro efetivo pelo número de repetições.

Para que as estimativas do modelo pudessem ser obtidas foram necessárias as seguintes restrições :

$$
\begin{array}{ll}
\sum_{i} \hat{g}_{i}=0 & i=1,2, \ldots, 8 \\
\sum_{j} \hat{s}_{i j}=0 & \mathrm{j}=1,2, \ldots, 8
\end{array}
$$

Para verificar se existem diferenças entre os efeitos das capacidades geral e especifica de combinação foram realizadas análises de variâncias segundo Vencovsky \& Barriga (1992). As estimativas das soma de quadrados foram obtidos por:

$$
\begin{gathered}
S Q_{g}=R(g / \mu)=R(\mu, g)-R(\mu) ; \\
S Q_{s}=Y^{\prime} Y-R(\mu, g) ;
\end{gathered}
$$

onde: - $S Q_{g}$ é a soma de quadrados devido aos efeitos da capacidade geral de combinação;

- $S Q_{s}$ é a soma de quadrados devido aos efeitos da capacidade específica de combinação;

- $R(\mu, g)$ é a soma de quadrados total do modelo;

- $R(\mu)$ é a soma de quadrados do modelo reduzido $Y_{i j}=\mu_{j}+e_{i j}$;

- Y'Y é a soma de quadrados de tratamentos.

3.5.2 Dialelo parcial incluindo apenas as populações derivadas do cruzamento de linhagens adaptadas com não adaptadas.

Também foi realizada a análise de um dialelo parcial formado apenas pelas populações originadas dos cruzamentos entre os genitores adaptados $(1,2,3,4$ e 5$)$ 
com os genitores não adaptados (6,7 e 8). Portanto, esta análise incluiu 14 populaçőes, visto que o cruzamento $2 \times 7$ năo estava disponível.

Foi utilizado o modelo I de Griffing, método 4, adaptado a dialelos parciais (Cruz \& Regazzi, 1997):

$$
\bar{Y}_{i j .}=\mu+g_{i}+g_{j}^{\prime}+s_{i j}+\bar{e}_{i j .}
$$

onde: $-\bar{Y}_{\mathrm{ij} .}$ é a média de $\mathrm{k}$ repetições da população formada pelo cruzamento entre o genitor i e o genitor $\mathrm{j}$;

- $\mu$ é a média geral da tabela dialélica;

- $g_{i}$ é o efeito devido à capacidade geral de combinação do genitor adaptado $i$;

- $g_{j}$ é o efeito devido à capacidade geral de combinação do genitor não adaptado j;

- $s_{\mathrm{ij}}$ é o efeito da capacidade específica de combinação para a população formada pelo cruzamento entre os genitores i e j, respectivamente adaptado e não adaptado;

- $\overline{\mathrm{e}}_{\mathrm{ij} \text {. }}$ é o erro médio obtido da análise de variância segundo o delineamento látice, dividindo-se o erro efetivo pelo número de repetições.

Para este dialelo parcial as restrições impostas foram:

$$
\begin{array}{ll}
\sum_{i} \hat{g}_{i}=0 i=1,2,3,4 \text { e } 5 & \sum_{j} \hat{g}_{j}^{\prime}=0 j=6,7 \text { e } 8 \\
\sum_{j} \hat{s}_{i j}=0 i=1,2,3,4 \text { e } 5 & \sum_{i} \hat{s}_{i j}=0 j=6,7 \text { e } 8
\end{array}
$$

Para verificar se existem diferenças entre os efeitos das capacidades de combinação geral e específica foram realizadas análises de variâncias utilizando as médias das populações. As expressões matriciais foram extraídas de Searle (1987), considerando o modelo reduzido com restrições ( $\Sigma$-restrictions), na ausência de interação:

$$
Y_{i j}=\mu+g_{i}+g_{i}+e_{i j}
$$


As somas de quadrados foram obtidas através das expressöes:

$S Q_{g_{i}}=R\left(g_{i} / \mu, g_{j}\right)=R\left(\mu, g_{i}, g_{j}\right)-R\left(\mu, g_{j}\right)$

$S Q_{g j}=R\left(g_{j} / \mu, g_{i}\right)=R\left(\mu, g_{i}, g_{j}\right)-R\left(\mu, g_{i}\right)$

$S Q_{s}=Y^{\prime} Y-R\left(\mu, g_{i}, g_{j}\right)$

onde: - $S Q_{g i}$ é a soma de quadrados devido aos efeitos da capacidade geral de combinação dos genitores adaptados;

- $S Q_{g j}$ é a soma de quadrados devido aos efeitos da capacidade geral de combinação dos genitores não adaptados;

- $S Q_{s}$ é a soma de quadrados devido aos efeitos da capacidade específica de combinação;

- $R\left(\mu, g_{i}, g_{j}\right)$ é a soma de quadrados do modelo reduzido $Y_{i j}=\mu+g_{i}+g_{j}+e i j$;

- $R\left(\mu, g_{i}\right)$ é a soma de quadrados do modelo reduzido $Y_{i j}=\mu+g_{i}+e_{i j}$;

- $R\left(\mu, g_{j}\right)$ é a soma de quadrados do modelo reduzido $Y_{i j}=\mu+g_{j}+e_{i j}$.

- Y'Y é a soma de quadrados de tratamentos.

A soma de quadrados do resíduo foi obtida segundo Vencovsky \& Barriga (1992), utilizando os quadrados médios do resíduo obtidos na análise de variância realizada para comparar as populações $F_{2: n}$.

\subsubsection{Análise dialélica da geração $\mathrm{F}_{2}{ }^{1}$}

Procedimentos idênticos aos descritos nos itens 3.5.1 e 3.5.2 foram utilizados para reavaliar os dados obtidos por Pimentel (1991). Portanto, da mesma maneira que para as populações endogâmias, estas gerações foram avaliadas segundo o modelo I de Griffing, método 4.

\footnotetext{
${ }^{1}$ Análise previamente realizada por Pulcinelli (1997) para os caracteres produção de grãos e altura das plantas na maturação. As análises foram refeitas neste trabalho com nenhuma ou poucas alterações.
} 
3.6 Proporção de linhagens superiores

Para verificar que populações apresentaram maior potencial para fins de melhoramento, foram calculadas as proporções de progênies dentro de cada população que possuiam médias acima da média de todas as 493 progênies.

\subsection{Calculo da distância euclidiana}

A distância euclidiana foi obtida a partir das médias dos genitores, estandardizadas pela respectiva variância fenotípica, dos seis caracteres estudados. Para a obtenção das estimativas, utilizou-se a expressão (Sneath \& Sokal 1973):

$$
\left.E_{i j}=\sqrt{\sum_{k}\left(x_{k i}-x_{k j}\right.}\right)^{j}
$$

onde: - $E_{i j}$ é a distância euclidiana entre os genitores i e j;

- $x_{k j}$ é a média estandardizada do genitor i no caráter $k$;

- $x_{k j}$ é a média estandardizada do genitor j no caráter $k$.

3.8 Avaliação dos genitores com marcadores moleculares RAPD.

Os genitores foram avaliados com marcadores moleculares do tipo RAPD (Random Amplified Primer Polymorphic DNA). As etapas para obtenção dos marcadores são descritas a seguir:

\subsubsection{Extração do DNA}

Para cada genótipo, quatro folhas trifoliadas, não completamente expandidas foram usadas na extração e purificação do DNA genômico. O método empregado foi descrito por Rogers \& Bendich (1985). 
O DNA obtido foi quantificado em géis de agarose $0,8 \%(p / v)$ através da comparação visual da intensidade das bandas do DNA extraido das linhagens de soja com bandas do DNA do fago lambda com concentrações conhecidas.

\subsubsection{Amplificação do DNA}

As reações de amplificação foram realizadas em solução contendo tampão

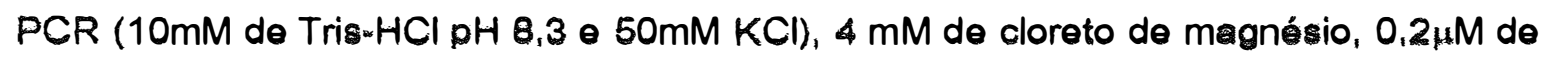
primer, 1,5 unidades de Taq DNA polimerase, 0,2mM de dNTP e DNA genômico das linhagens. Cada um dos genótipos foi amplificado com 96 deoxioligonuclotídeos com 10 pares de base, pertencentes aos Kits A, B, C, D, E e F (Operon).

Após a desnaturação inicial a $94^{\circ} \mathrm{C}$ por 5 minutos, 45 ciclos de amplificação foram realizados. Cada ciclo foi constituido por uma desnaturação do DNA a $94^{\circ} \mathrm{C}$ por 1 minuto, um anelamento do primer a $35^{\circ} \mathrm{C}$ por 1 minuto e uma amplificação do DNA a $72^{\circ} \mathrm{C}$ por 2 minutos. Ao final dos 45 ciclos, uma extensão adicional de 5 minutos a $72^{\circ}$ foi realizada.

Para cada combinação genótipo/primer foram realizadas duas reações simultâneas, mas com concentrações de DNA genômico diferentes: 40ng e 60ng. Apenas os produtos de amplificação presentes em ambas as reações foram considerados suficientemente consistentes para serem utilizados na análise.

Os produtos de amplificação foram separados por eletroforese em gel de agarose $1,4 \%(\mathrm{p} / \mathrm{v})$, utilizando o tampão TBE (0.09M tris, 0.09M ácido bórico e $2 \mathrm{mM}$ EDTA). Os géis foram corados com brometo de etídio $10 \mathrm{mg} / \mathrm{ml}$ e documentados sob luz UV.

\subsubsection{Cálculo da distância genética}

As estimativas da distância genética foram obtidas pela avaliação dos marcadores que revelaram polimorfismo em pelo menos uma linhagem. A similaridade genética entre as linhagens foi calculada segundo o coeficiente de Simple Matching (Sneath \& Sokal 1973): 


$$
S M_{i j}=\frac{a+b}{a+b+c+d}
$$

onde: - $S M_{i j}$ é a similaridade genética entre os genótipos i e j;

- a é o número marcadores presentes em i e j :

- $b$ é o número de marcadores presentes em i e ausentes em j;

- c é o número de marcadores ausentes em i e presentes em j;

- dé o número de marcadores ausentes em i e j.

O coeficiente de similaridade foi convertido para distância genética (DG) pela expressão:

$$
D G_{i j}=1-S M_{i j}
$$

onde: $\mathrm{DG}_{\mathrm{ij}}$ é a distância genética entre os genótipos $i$ e $j$.

\subsubsection{Análise bootstrap}

Para verificar se o número detectado de marcadores RAPD polimórficos foi suficiente para obter estimativas precisas da distância genética entre os genótipos, empregou-se um procedimento de reamostragem utilizando a técnica bootstrap (Tivang et al., 1994).

Os marcadores polimórficos foram submetidos a 200 reamostragens com reposição de tamanho igual a 13. As distâncias genéticas foram estimadas para cada amostra de marcadores havendo, portanto, 200 estimativas de distância genética para cada combinação de genótipos. A média, a variância e o coeficiente de variação foram estimados para cada uma destas combinações. A partir dos 28 coeficientes de variação estimados, um para cada combinação de genótipos, obteve-se um coeficiente de variação médio. Todo o procedimento foi repetido para tamanhos amostrais crescentes, sendo que a cada novo procedimento reamostral o número de marcadores foi igual ao anterior acrescido de 10. Deste modo, o segundo procedimento foi realizado com amostras de 23 marcadores, o terceiro com 33 marcadores e assim 
sucessivamente até que o tamanho da amostra fosse igual ao número de total de marcadores polimórficos obtidos.

As expressões utilizadas para a obtenção destas estimativas foram:

$$
\overline{D G}_{i j(K)}=\frac{\sum_{m=1}^{m} D G_{i j m(K)}}{m}
$$

onde: $-\widehat{\mathrm{DG}}_{\mathrm{ij}(\mathrm{K})}$ é a média da distância genética entre os genótipos i e j, no tamanho amostral K;

- DG $\mathrm{ijm(K)}$ é a distância genética dos genótipos i e j na emézima amostra de tamanho K;

- $m$ é o número total de amostras de tamanho $K$ tomadas a partir dos dados originais;

$$
\sigma_{D G_{i j(K)}}^{2}=\frac{\sum_{1}^{m}\left(\bar{D} \bar{G}_{i j(K)}-D G_{i j n(K)}\right)^{2}}{m-1}
$$

onde: $-\sigma_{\mathrm{DG}_{\mathrm{i}(\mathrm{K})}}^{2}$ é a variância da distância genética entre os genótipos i e j, no tamanho amostral K.

$$
C V_{i j(K)}=\frac{\sqrt{\sigma_{D G_{i j(K)}^{2}}}}{\overline{D G}_{i j(K)}}
$$

onde: - $\mathrm{CV}_{\mathrm{ij}(\mathrm{K})}$ é o coeficiente de variação da distância genética entre os genótipos i e j, no tamanho amostral $\mathrm{K}$.

$$
\overline{C V}_{k}=\frac{\sum_{1}^{n} C V_{i j}}{g(g-1) 0,5}
$$

onde: $-\overline{\mathrm{CV}}_{\mathrm{k}}$ é o coeficiente de variação médio das distâncias genéticas obtido no tamanho amostral $\mathrm{K}$;

- g é o número de genótipos avaliados por marcadores. 
O tamanho amostral e o coeficiente de variação médio foram utilizados na construção de um diagrama de dispersão. A inspeção visual deste diagrama permitiu verificar se o número de marcadores obtidos foi suficiente para a obtenção de estimativas consistentes das distâncias genéticas.

3.9 Partição das distâncias genéticas em distância genética geral e distância genética especifica

As distâncias genéticas foram divididas em um componente médio, um componente geral, denominado distância genética geral (DGG) e um componente específico, denominado distância genética específica (DGE), empregando uma metodologia semelhante a uma análise dialélica de Griffing modelo 1 método 4 (Melchinger et al., 1990b). Este procedimento foi realizado considerando-se todas as 28 combinações possíveis entre os oito genitores e considerando apenas as 15 combinações entre os genitores adaptados (1, 2, 3, 4 e 5) e não adaptados (6, 7 e 8).

Esta partição foi realizada para a distância genética obtida pela análise dos marcadores e também para a distância euclidiana.

3.9.1 Partição das distâncias genéticas considerando as 28 combinações entre genitores

Para obter as DGG's e as DGE's foram considerados as distâncias genéticas das 28 combinações entre os oito genitores. O modelo empregado foi:

$$
D G_{i j}=\overline{D G}+D G G_{i}+D G G_{j}+D G E_{i j}
$$

onde: - $\overline{D G}$ é a distância genética média;

- $D G_{i j}$ é a distância genética entre o genótipo i e o genótipo j;

- $D G G_{i}$ e $D G G_{j}$ são os efeitos devido às distâncias genéticas gerais do genitor $i$ e do genitor $\mathrm{j}$, respectivamente; 
- DGE $E_{\mathrm{ij}}$ é o efeito devido a distância genética específica entre os genitores i e j.

Para a obtenção das estimativas foram utilizadas as seguintes restrições :

$$
\sum_{i} D G G_{i}=0 \quad \mathrm{i}=1,2,3,4,5,6,7 \text { e } 8 \quad \sum_{j} D G E_{i j}=0
$$

3.9.2 Partição das distâncias genéticas considerando as 15 combinações entre genitores adaptados e não adaptados

As DGG's e as DGE's foram obtidas a partir da análise das 15 distâncias entre genitores adaptados e não adaptados. O modelo empregado foi:

$$
D G_{i j}=\overline{D G}+D G G_{i}+D G G_{j}^{\prime}+D G E_{i j}
$$

onde: - $\overline{D G}$ é a distância genética média;

- DG ${ }_{i j}$ é a distância genética entre o genótipo i e o genótipo j;

- DGG i é o efeito devido à distância genética geral do genitor adaptado i;

- DGG; é o efeito devido à distância genética geral do genitor não adaptado j;

- DGE $E_{i j}$ é o efeito devido a distância genética específica entre os genitores i e j.

Para a obtenção das estimativas foram utilizadas as seguintes restrições :

$$
\begin{array}{ll}
\sum_{i} D G G_{i}=0 \quad i=1,2,3,4 \text { e } 5 & \sum_{j} D G G_{j}=0 j=6,7 \text { e } 8 \\
\sum_{j} D G E_{i j}=0 i=1,2,3,4 \text { e } 5 & \sum_{i} D G E_{i j}=0 j=6,7 \text { e } 8
\end{array}
$$




\section{RESULTADOS E DISCUSSÃO}

4.1 Análise das linhagens genitoras

\subsubsection{Produção de grãos}

Os resultados das análises de variância para o caráter produção de grãos podem ser observados na Tabela 3 . Verificou-se a existência de diferenças significativas entre os genitores nos dois anos avaliados e na análise conjunta. Os experimentos apresentaram uma boa precisão, com coeficientes de variação entre $17,94 \%$ e $15,17 \%$. A análise conjunta permitiu verificar que a interação das populações com os anos foi significativa, mostrando que a avaliação das linhagens genitoras em mais de um ano fomeceu estimativas mais precisas das médias.

A comparação entre as médias dos genitores segundo o teste de Tukey (Tabela 4) mostrou que as linhagens adaptadas (1, 2, 3, 4 e 5) foram mais produtivas que as linhagens não adaptadas (6, 7 e 8). Entre as adaptadas, as linhagens 4 e 1 apresentaram a maior e a menor média, respectivamente. Os genitores não adaptados foram significativamente diferentes no ano de 1997/98, mas não em 1996/97 e na análise conjunta. 
Tabela 3. Análises de variância dos genitores para o caracter produção de grãos, nos dois anos de avaliação e na análise conjunta.

\begin{tabular}{|c|c|c|c|c|c|c|}
\hline \multirow[b]{2}{*}{ Fonte } & \multicolumn{2}{|r|}{$1996 / 1997$} & \multicolumn{2}{|r|}{$1997 / 1998$} & \multicolumn{2}{|c|}{ Conjunta } \\
\hline & DF & QM & $D F$ & QM & $\mathrm{Gl}$ & $\mathrm{QM}$ \\
\hline Repetição & 9 & 63683,20 & 9 & 10577,46 & & \\
\hline Repetição/ano & 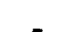 & - & - & - & 9 & 109979,41 \\
\hline Anos & - & - & 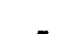 & - & 1 & $483742,17^{\star \star}$ \\
\hline Genitor & 7 & $793047,06^{\star *}$ & 7 & $143956,29^{\star \star}$ & 7 & $1556812,13^{\star *}$ \\
\hline ivs ano & 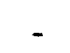 & - & 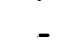 & , & 7 & $236621,62^{\star \star}$ \\
\hline Resíduo & 61 & 36682,49 & 63 & 21057,45 & 133 & 30107,97 \\
\hline $\begin{array}{l}\text { Média (gramas) } \\
\text { CV\% }\end{array}$ & & $\begin{array}{c}1067,49 \\
17,94\end{array}$ & & $\begin{array}{c}956,50 \\
15,17\end{array}$ & & $\begin{array}{c}1011,29 \\
17,16\end{array}$ \\
\hline
\end{tabular}

Tabela 4. Média dos genitores para o caráter produção de grãos, em gramas por parcela, nos dois anos de avaliação e na análise conjunta.

\begin{tabular}{ccccc}
\hline Genitor & $1996 / 1997$ & $1997 / 1998$ & Conjunta \\
\hline 1 & 1338,60 & $\mathrm{~A}$ & $783,2 \mathrm{C}$ & $1060,90 \mathrm{C}$ \\
2 & 1124,04 & $\mathrm{~A}$ & $1158,8 \mathrm{~B}$ & $1138,43 \mathrm{BC}$ \\
3 & $1227,40 \mathrm{~A}$ & $1176,0 \mathrm{AB}$ & $1201,70 \mathrm{BC}$ \\
4 & $1394,60 \mathrm{~A}$ & $1370,0 \mathrm{~A}$ & $1382,30 \mathrm{~A}$ \\
5 & $1220,20 \mathrm{~A}$ & $1247,2 \mathrm{AB}$ & $1233,70 \mathrm{AB}$ \\
6 & 791,40 & $\mathrm{~B}$ & $574,4 \mathrm{DE}$ & $682,90 \mathrm{D}$ \\
7 & $800,60 \mathrm{~B}$ & $566,4 \mathrm{E}$ & $683,50 \mathrm{D}$ \\
8 & $648,20 \mathrm{~B}$ & $776,0 \mathrm{CD}$ & $712,10 \mathrm{D}$ \\
\hline
\end{tabular}

\subsubsection{Altura das plantas na maturação}

As linhagens genitoras apresentaram diferenças quanto à altura na maturação. Estas diferenças foram verificadas na análise dos anos individuais e na análise conjunta. (Tabela 5). Os experimentos apresentaram uma boa precisão, com coeficientes de variação entre $6,37 \%$ e $8,14 \%$. A análise conjunta permitiu verificar que a interação entre genitores e anos foi significativa, mostrando que a avaliação das linhagens em mais de um ano forneceu estimativas mais precisas das médias.

A comparação entre as médias dos genitores pelo teste de Tukey permitiu verificar que a linhagem 8 apresentou a maior altura média na maturação (Tabela 6). As menores médias foram verificadas para o genitor 6, embora no ano de 1996/97 sua 
média não tenha sido diferente das observadas para a maioria dos genitores adaptados. Entre os genitores adaptados, a linhagem 2 é a mais alta ao final do ciclo.

Tabela 5. Análises de variância dos genitores para o caracter altura das plantas na maturação, nos dois anos de avaliação e na análise conjunta.

\begin{tabular}{|c|c|c|c|c|c|c|}
\hline \multirow[b]{2}{*}{ Fonte } & \multicolumn{2}{|r|}{$1996 / 1997$} & \multicolumn{2}{|r|}{$1997 / 1998$} & \multicolumn{2}{|c|}{ Conjunta } \\
\hline & DF & QM & DF & QM & GI & QM \\
\hline Repetição & 9 & 97,53 & 9 & $457,54^{\star \star}$ & - & - \\
\hline Repetição/ano & - & - & - & - & 9 & 429,36 \\
\hline Anos & - & - & - & - & 1 & $425,27^{\star \star *}$ \\
\hline Genitor & 7 & $3143,38^{\star \star}$ & 7 & $3788,22^{\star \star}$ & 7 & $6028,48^{\star \star}$ \\
\hline Genitor vs ano & - & - & - & - & 7 & $816,11^{\text {** }}$ \\
\hline Residuo & 61 & 30,15 & 63 & 45,87 & 133 & 44,06 \\
\hline Média $(\mathrm{cm})$ & & 86,17 & & 83,21 & & 4,67 \\
\hline CV\% & & 6,37 & & 8,14 & & 7,84 \\
\hline
\end{tabular}

Tabela 6. Média dos genitores para o caráter altura das plantas na maturação, em centimetros, nos dois anos de avaliação e na análise conjunta.

\begin{tabular}{crrrrr}
\hline Genitor & $1996 / 1997$ & \multicolumn{1}{c}{$1997 / 1998$} & Conjunta \\
\hline 1 & $76,89 \mathrm{D}$ & $69,15 \mathrm{CD}$ & $73,02 \mathrm{C}$ \\
2 & $100,08 \mathrm{~B}$ & $103,68 \mathrm{AB}$ & 101,88 & $\mathrm{~B}$ \\
3 & $78,34 \mathrm{D}$ & $68,33 \mathrm{CD}$ & 73,33 & $\mathrm{C}$ \\
4 & $74,71 \mathrm{D}$ & $75,20 \mathrm{C}$ & 74,96 & $\mathrm{C}$ \\
5 & $75,16 \mathrm{D}$ & $75,08 \mathrm{C}$ & 75,12 & $\mathrm{C}$ \\
6 & $71,87 \mathrm{D}$ & $60,54 \mathrm{D}$ & 66,21 & $\mathrm{D}$ \\
7 & $90,77 \mathrm{C}$ & $111,90 \mathrm{~A}$ & 101,34 & $\mathrm{~B}$ \\
8 & $123,91 \mathrm{~A}$ & $101,82 \mathrm{~B}$ & 112,87 & $\mathrm{~A}$ \\
\hline
\end{tabular}

Médias seguidas de letras distintas são diferentes ao nível de $5 \%$

\subsubsection{Número de dias para a maturação}

Os resultados das análises de variância para o caráter número de dias para a maturação podem ser observados na Tabela 7. Verificou-se que as linhagens genitoras não apresentaram o mesmo número de dias para a maturação em nenhuma das análises realizadas. Os experimentos apresentaram uma alta precisão, com coeficientes de variação entre $2,34 \%$ e $0,93 \%$. A análise conjunta permitiu verificar que 
a interação das populações com os anos foi significativa, mostrando que a avaliação dos genitores em mais de um ano resultou em estimativas mais precisas das médias.

A comparação entre as médias dos genitores mostrou que as linhagens 8 e 6 foram as que apresentaram a maior e a menor média, respectivamente (Tabela 8). Os demais genitores apresentaram pequenas diferenças com relação ao número de dias para o final do ciclo, havendo uma tendência dos genitores 1 e 2 serem mais tardios e os genitores $3,4,5$ e 7 mais precoces.

Tabela 7. Análises de variância dos genitores para o caracter dias para a maturação, nos dois anos de avaliação e na análise conjunta.

\begin{tabular}{l|cc|cc|cc}
\hline \multirow{2}{*}{ Fonte } & \multicolumn{3}{|c|}{$1996 / 1997$} & \multicolumn{2}{|c|}{$1997 / 1998$} & \multicolumn{2}{c}{ Conjunta } \\
\cline { 2 - 7 } & DF & QM & DF & QM & GI & QM \\
\hline Repetição & 9 & 13,98 & 9 & 0,74 & - & - \\
Repetição/ano & - & - & - & - & 9 & 5,90 \\
Anos & - & - & - & - & 1 & $9019,97^{\star \star}$ \\
Genitor & 7 & $396,40^{\star \star}$ & 7 & $294,97^{\star \star}$ & 7 & $604,87^{\star \star}$ \\
Genitor vs ano & - & - & - & - & 7 & $87,94^{\star \star}$ \\
Residuo & 61 & 8,49 & 63 & 1,70 & & 5,30 \\
\hline Média (dias) & & 124,68 & & 139,90 & & 132,39 \\
CV\% & & 2,34 & & 0,93 & & 1,74 \\
\hline
\end{tabular}

Tabela 8. Média dos genitores para o caráter dias para maturação, em dias, nos dois anos de avaliação e na análise conjunta.

\begin{tabular}{clll}
\hline Genitor & $1996 / 1997$ & $1997 / 1998$ & Conjunta \\
\hline 1 & $126,60 \mathrm{BC}$ & $141,80 \mathrm{AB}$ & $134,20 \mathrm{BC}$ \\
2 & $127,93 \mathrm{~B}$ & $141,60 \mathrm{~B}$ & $134,76 \mathrm{~B}$ \\
3 & $124,70 \mathrm{BCD}$ & $141,60 \mathrm{~B}$ & $133,15 \mathrm{CD}$ \\
4 & $123,10 \mathrm{CD}$ & $141,20 \mathrm{~B}$ & $132,15 \mathrm{CD}$ \\
5 & $123,60 \mathrm{CD}$ & $141,00 \mathrm{~B}$ & $132,30 \mathrm{CD}$ \\
6 & $114,30 \mathrm{E}$ & $126,60 \mathrm{C}$ & $120,45 \mathrm{E}$ \\
7 & $121,20 \mathrm{D}$ & $141,80 \mathrm{AB}$ & $131,50 \mathrm{D}$ \\
8 & $136,60 \mathrm{~A}$ & $143,60 \mathrm{~A}$ & $140,10 \mathrm{~A}$ \\
\hline
\end{tabular}




\subsubsection{Altura das plantas no florescimento}

A análise de variância revelou que as linhagens genitoras não apresentaram a mesma altura ao final do período vegetativo (Tabela 9). As diferenças foram verificadas tanto nos anos individuais quanto na análise conjunta. Os experimentos apresentaram uma boa precisão, com coeficientes de variação entre 10,71\% e 9,99\%. A análise conjunta permitiu verificar que a interação das populações com anos foi significativa, indicando que as médias obtidas nos anos individuais foram menos precisas do que as obtidas na análise conjunta.

A comparação entre as médias (Tabela 10) permitiu verificar que os genitores 8 e 6 foram os que apresentaram a maior e a menor altura média no florescimento, respectivamente. Os demais genitores apresentaram médias semelhantes, sendo as diferenças não significativas em 1997/98 e na análise conjunta.

Tabela 9. Análises de variância dos genitores para o caracter altura das plantas no florescimento, nos dois anos de avaliação e na análise conjunta.

\begin{tabular}{l|cc:cc:cc}
\hline & \multicolumn{3}{c}{$1996 / 1997$} & & $1997 / 1998$ & \multicolumn{1}{c}{ Conjunta } \\
\cline { 2 - 7 } Fonte & DF & QM & DF & QM & GI & QM \\
\hline Repetição & 9 & 122,91 & 9 & 40,92 & - & - \\
Repetição/ano & & & & & 9 & 66,41 \\
Anos & & & & & 1 & 3,37 \\
Genitor & 7 & $709,63^{\star \star}$ & 7 & $449,37^{\star \star}$ & 7 & $1045,35^{\star \star}$ \\
Genitor vs ano & & & & & 7 & $119,73^{\star *}$ \\
Resíduo & 60 & 33,29 & 63 & 32,27 & 132 & 37,18 \\
\hline Média (cm) & & 57,02 & & 56,85 & & 56,93 \\
CV\% & & 10,12 & & 9,99 & & 10,71 \\
\hline
\end{tabular}

Tabela 10. Média dos genitores para o caráter altura das plantas no florescimento, em centimetros, nos dois anos de avaliação e na análise conjunta.

\begin{tabular}{cccc}
\hline Genitor & $1996 / 1997$ & $1997 / 1998$ & Conjunta \\
\hline 1 & $59,40 \mathrm{~B}$ & $57,27 \mathrm{~B}$ & $58,34 \mathrm{~B}$ \\
2 & $55,54 \mathrm{BC}$ & $54,86 \mathrm{~B}$ & $55,41 \mathrm{~B}$ \\
3 & $55,13 \mathrm{BC}$ & $54,34 \mathrm{~B}$ & $54,74 \mathrm{~B}$ \\
4 & $61,22 \mathrm{~B}$ & $56,07 \mathrm{~B}$ & $58,65 \mathrm{~B}$ \\
5 & $54,65 \mathrm{BC}$ & $56,82 \mathrm{~B}$ & $55,73 \mathrm{~B}$ \\
6 & $46,07 \mathrm{D}$ & $45,63 \mathrm{C}$ & $45,85 \mathrm{C}$ \\
7 & $49,74 \mathrm{CD}$ & $60,00 \mathrm{~B}$ & $54,87 \mathrm{~B}$ \\
8 & $75,09 \mathrm{~A}$ & $69,80 \mathrm{~A}$ & $72,39 \mathrm{~A}$ \\
\hline
\end{tabular}

Médias seguidas de letras distintas são diferentes ao nível de $5 \%$ 


\subsubsection{Número de dias para o florescimento}

Os resultados das análises de variância para o caráter número de dias para o florescimento podem ser observados na Tabela 11. Verificou-se a existência de diferenças significativas entre as linhagens nos dois anos avaliados e na análise conjunta. Os experimentos apresentaram excelente precisão, com coeficientes de variação entre $1,22 \%$ e $1,46 \%$. A análise conjunta mostrou que a interação das populações com os anos foi significativa. Portanto, a avaliação das linhagens genitoras em mais de um ano permitiu obter estimativas mais precisas das médias.

Verificou-se que os genitores 8 e 6 apresentaram a maior e a menor média, respectivamente (Tabela 12 ).

Tabela 11. Análises de variância dos genitores para o caracter dias para o florescimento, nos dois anos de avaliação e na análise conjunta.

\begin{tabular}{l|cc|cc|cc}
\hline \multirow{2}{*}{ Fonte } & \multicolumn{2}{|c|}{$1996 / 1997$} & \multicolumn{2}{c|}{$1997 / 1998$} & \multicolumn{2}{c}{ Conjunta } \\
\cline { 2 - 7 } & DF & QM & DF & QM & GI & QM \\
\hline Repetição & 9 & 1,629 & 9 & 0,300 & - & - \\
Repetição/ano & - & - & - & - & 9 & 0,748 \\
Anos & - & - & - & - & 1 & $21,812^{\star \star}$ \\
Genitor & 7 & $154,372^{\star \star}$ & 7 & $252,164^{\star \star}$ & 7 & $375,998^{\star \star}$ \\
Genitor vs ano & - & - & - & - & 7 & $29,165^{\star \star}$ \\
Residuo & 61 & 0,612 & 63 & 0,414 & 133 & 0,557 \\
\hline Média (dias) & & 53,69 & & 52,98 & & 53,33 \\
CV\% & & 1,46 & & 1,22 & & 1,40 \\
\hline
\end{tabular}

Tabela 12. Média dos genitores para o caráter dias para o florescimento, em dias, nos dois anos de avaliação e na análise conjunta.

\begin{tabular}{cllll}
\hline Genitor & $1996 / 1997$ & \multicolumn{1}{c}{$1997 / 1998$} & Conjunta \\
\hline 1 & $53,30 \mathrm{C}$ & $50,00 \mathrm{C}$ & $51,65 \mathrm{CD}$ \\
2 & $54,92 \mathrm{~B}$ & $49,80 \mathrm{C}$ & $52,36 \mathrm{C}$ \\
3 & $52,00 \mathrm{D}$ & $53,00 \mathrm{~B}$ & $52,50 \mathrm{BC}$ \\
4 & $52,90 \mathrm{CD}$ & $53,20 \mathrm{~B}$ & $53,05 \mathrm{~B}$ \\
5 & $52,00 \mathrm{D}$ & $50,00 \mathrm{C}$ & $51,00 \mathrm{D}$ \\
6 & $49,50 \mathrm{E}$ & $50,00 \mathrm{C}$ & $49,75 \mathrm{E}$ \\
7 & $52,40 \mathrm{CD}$ & $53,00 \mathrm{~B}$ & $52,70 \mathrm{BC}$ \\
8 & $62,70 \mathrm{~A}$ & $64,80 \mathrm{~A}$ & $63,75 \mathrm{~A}$ \\
\hline
\end{tabular}

Médias seguidas de letras distintas são diferentes ao nivel de $5 \%$ 


\subsubsection{Acamamento}

As notas aplicadas para avaliar o acamamento das linhagens não apresentaram distribuição normal. Para aproximar a distribuição das notas da distribuição normal, os dados originais foram transformados por $\sqrt{\mathrm{x}+1}$.

Após a transformação, a análise de variância mostrou que as linhagens não apresentam o mesmo nivel de acamamento (Tabela 13). O experimento apresentou uma boa precisão, com coeficiente de variação de $4,51 \%$.

As linhagens 1, 3, 4, 5 e 6 não apresentaram plantas acamadas em nenhuma das parcelas. Os maiores niveis de acamamento foram verificados nas linhagens 7,8 e 2, em ordem crescente (Tabela 14).

Tabela 13. Análise de variância dos pais para o caracter acamamento, transformado por $\sqrt{\mathrm{x}+1}$, avaliado no ano agricola de 1997/1998.

\begin{tabular}{lcl}
\hline Fonte & GL & \multicolumn{1}{c}{ QM } \\
\hline Repetição & 9 & 0,00720 \\
Genitor & 7 & $1,66938^{\star *}$ \\
Resíduo & 63 & 0,00574 \\
\hline Média & & 1,68 \\
CV\% & & 4,51 \\
\hline
\end{tabular}

Tabela 14. Média dos genitores para o caráter acamamento em 1997/98

\begin{tabular}{crc}
\hline Genitor & Média & Média Transformada \\
\hline 1 & 1,00 & $1,41 \mathrm{D}$ \\
2 & 2,20 & $1,78 \mathrm{C}$ \\
3 & 1,00 & $1,41 \mathrm{D}$ \\
4 & 1,00 & $1,41 \mathrm{D}$ \\
5 & 1,00 & $1,41 \mathrm{D}$ \\
6 & 1,00 & $1,41 \mathrm{D}$ \\
7 & 5,00 & $2,45 \mathrm{~A}$ \\
8 & 3,60 & $2,14 \mathrm{~B}$ \\
\hline
\end{tabular}

Médias seguidas de letras distintas são diferentes ao nível de $5 \%$ 


\subsubsection{Considerações a respeito das avaliações das linhagens genitoras}

Os resultados obtidos nos experimentos realizados para avaliar os genitores mostram que as linhagens adaptadas são mais produtivas e resistentes ao acamamento. Entre os genitores adaptados, a linhagem 2 foi a que mais se assemelhou aos não adaptados, apresentando valores mais elevados de acamamento, altura e ciclo que as demais adaptadas. Isto pode ser explicado em função deste genótipo não ter sido produzido no Brasil, mas ser uma linhagem introduzida dos EUA.

À exceção da produção de grãos, as linhagens não adaptadas apresentaram os valores extremos nos caracteres avaliados. A linhagem 6 foi a mais baixa no florescimento e na maturação fisiológica e que menor tempo levou para florescer e fechar o ciclo. A linhagem 8 apresentou os valores mais altos para estes mesmos caracteres. A linhagem 7 apresentou valores intermediários para todos os caracteres, à exceção de acamamento cujas notas foram as maiores obtidas. Portanto, estes genótipos detém a maior parte da variabilidade para a maioria dos caracteres avaliados. Scott \& Kephard (1997), também verificaram maior variabilidade entre linhagens de soja não adaptadas do que entre adaptadas, corroborando os obtidos neste trabalho.

Embora menos produtivos que as linhagens adaptadas, os genótipos não adaptados podem conter genes que contribuem para o aumento da produção diferentes dos encontrados nos genótipos adaptados, podendo ser empregados como fonte de variabilidade para programas de melhoramento (Schoener \& Fehr, 1979; Vello et al., 1984; Scott \& Kephard, 1997).

O experimento conduzido por Pimentel (1991) incluía a avaliação destas linhagens. Os resultados obtidos pelo autor foram muito semelhantes aos encontrados para a maioria dos caracteres. As maiores diferenças ficaram por conta do caráter produção de grãos. Ele verificou que a linhagem 8 apresentou maior produção do que as adaptadas 1 e 2 . Nas duas avaliações realizadas no presente trabalho a produção da linhagem 8 foi inferior em 1996/97 e semelhante à linhagem 1 em 1997/98 e sempre inferior à linhagem 2. Deve-se considerar que a linhagem 8 é a única não adaptada com hábito de crescimento indeterminado e que o espaçamento entre linhas nos experimentos realizados por Pimentel (1991) foram maiores (1 metro) do que o utilizado no presente trabalho (50 centimetros). Portanto, é provável que a melhor 
performance da linhagem 8 se deva ao favorecimento do desenvolvimento desta linhagem no ambiente existente durante a avaliação realizada por Pimentel (1991) e não à real superioridade genética desta linhagem em relação aos genótipos adaptados 1 e 2 .

4.2 Distância euclidiana entre as linhagens genitoras

As estimativas das distâncias euclidianas entre os genitores podem ser observadas na Tabela 15. A menor distância verificada foi 0,43 (entre os genótipos 3 e 5) e a maior 6,79 (entre 6 e 8).

A análise de agrupamento mostrou que os genitores adaptados (1, 2, 3, 4 e 5) formam um único cluster e que os genitores não adaptados não se agrupam (Figura 1). O coeficiente de correlação cofenética calculado foi 0,95 . Este valor mostra um grande ajuste entre a matriz de distâncias genéticas e o dendrograma.

Para melhor entender o agrupamento obtido é necessário considerar os valores utilizados para o cálculo das distâncias, ou seja, as médias dos genitores em cada caráter na análise conjunta. Verificou-se uma relativa homogeneidade entre as médias dos genitores adaptados, o que refletiu no agrupamento destes genótipos. Entre os genitores não adaptados as médias apresentaram valores bastante diferentes (à exceção de produção de grãos) o que impossibilitou o agrupamento destes genótipos. Comparando-se as médias dos dois grupos de genitores percebe-se que as diferenças também foram grandes, fazendo com que a estrutura do dendrograma fosse como a observada na Figura 1.

Tabela 15 Distância euclidiana entre os oito genitores.

\begin{tabular}{cccccccc}
\hline & 1 & 2 & 3 & 4 & 5 & 6 & 7 \\
\hline 2 & 1,89 & & & & & & \\
3 & 0,75 & 1,84 & & & & & \\
4 & 1,26 & 2,04 & 0,87 & & & & \\
5 & 0,81 & 1,83 & 0,43 & 0,81 & & & \\
6 & 3,36 & 4,02 & 3,28 & 3,82 & 3,26 & & \\
7 & 3,42 & 2,51 & 3,58 & 3,94 & 3,61 & 4,09 & \\
8 & 4,70 & 4,09 & 5,01 & 4,99 & 5,17 & 6,79 & 3,98 \\
\hline
\end{tabular}


Correlação cofenética $=0,95$

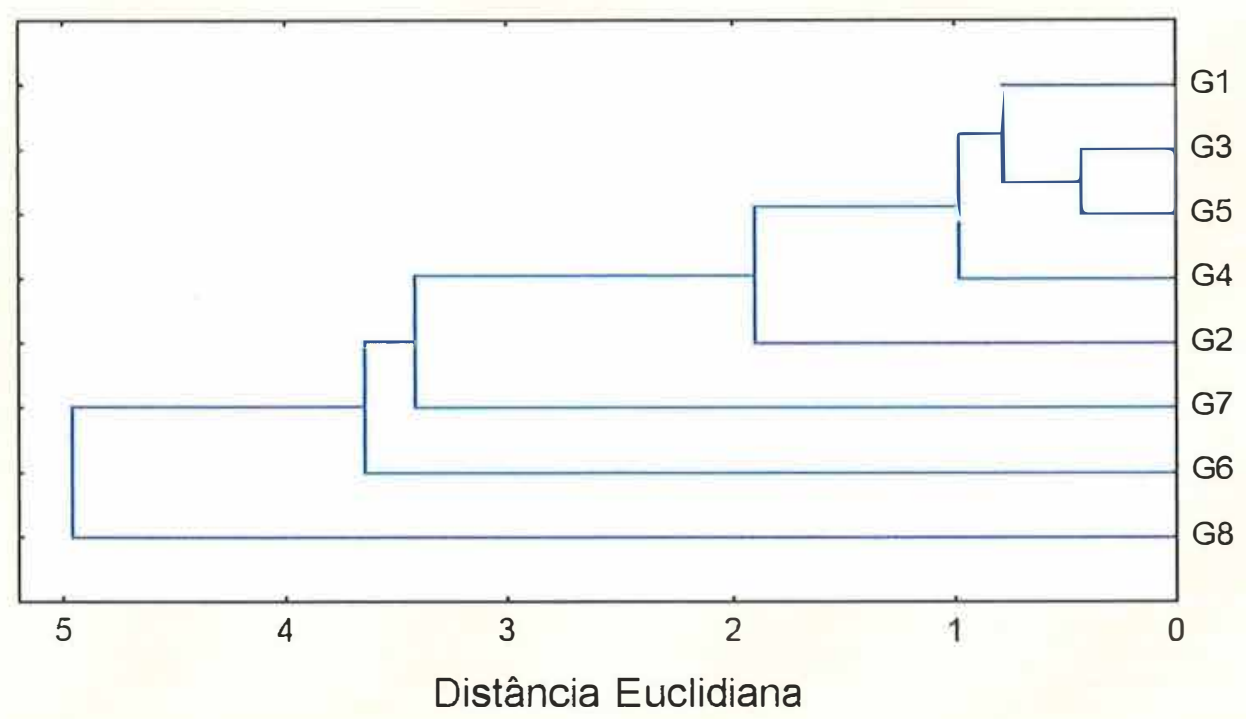

Figura 1 Correlação cofenética e agrupamento dos genitores (distância euclidiana).

4.2.1 Partição da distância euclidiana considerando todas as 28 combinações entre genitores

A partição das distâncias euclidianas mostrou que a distância euclidiana geral (DEG) (Tabela 16) explica a maior parte da variabilidade das distâncias euclidianas, com coeficiente de determinação $\left(R^{2}\right)$ igual a 0,84 . A distância euclidiana específica explicou $16 \%\left(R^{2}=0,16\right)$ das diferenças observadas entre as distâncias genéticas.

A importância relativa da DEG foi maior neste estudo do que as relatadas na literatura (Melchinger et al., 1990a, Melchinger et al., 1990b, Melchinger et al., 1992). De acordo com Freire Filho (1988), quando o conjunto de parentais é heterogêneo, espera-se que a capacidade geral de combinação seja superior a capacidade específica. Comparando os valores obtidos neste trabalho e as descritas na literatura, percebe-se que a distância euclidiana foi mais heterogenea do que as distâncias genéticas relatadas em milho (Melchinger et al., 1990a, Melchinger et al., 1990b, Melchinger et al., 1992). Como a partição da distância euclidiana foi realizada de modo semelhante à análise dialélica de Griffing modelo 1 método 4, a DEG é correspondente 
a capacidade geral de combinação. Portanto, a maior heterogeneidade das distâncias euclidianas devem ter resultado em maior importância da DEG do que da DEE.

Os valores positivos da DEG foram verificados nas linhagens não adaptadas. Segundo Melchinger et al. (1990), o valor positivo e alto da DEG indica que o genótipo apresenta um elevado número alelos que ocorrem em baixa freqüência no conjunto de genótipos estudados. Valor positivo e elevado da DEE indica que a heterozigose esperada do cruzamento é alta. Espera-se que as linhagens não adaptadas possuam um menor número de locos em comum, o que foi confirmado pela DEG positiva. Também se espera que os cruzamentos em que estejam envolvidas as linhagens não adaptadas apresentem um maior número de locos segregando, o que pode explicar a DEE positiva verificada nas combinações entre as linhagens adaptadas e não adaptadas.

Tabela 16. Estimativas das distâncias euclidiana gerais $\left(D E G_{i}\right)$ e especificas $\left(D E E_{i j}\right)$

\begin{tabular}{rrrrrrrrr}
\hline & & \multicolumn{7}{c}{ DEE $_{i j}$} \\
\cline { 3 - 9 } & DEG $_{i}$ & 1 & 2 & 3 & 4 & 5 & 6 & 7 \\
\hline$\mu$ & 3,077 & & & & & & & \\
1 & $-0,891$ & & & & & & & \\
2 & $-0,553$ & 0,257 & & & & & & \\
3 & $-0,963$ & $-0,473$ & 0,279 & & & & & \\
4 & $-0,635$ & $-0,291$ & 0,151 & $-0,609$ & & & & \\
5 & $-0,936$ & $-0,439$ & 0,242 & $-0,748$ & $-0,696$ & & & \\
6 & 1,180 & $-0,006$ & 0,316 & $-0,014$ & 0,197 & $-0,061$ & & \\
7 & 0,599 & 0,636 & $-0,613$ & 0,867 & 0,899 & 0,871 & $-0,766$ & \\
8 & 2,199 & 0,316 & $-0,633$ & 0,697 & 0,349 & 0,831 & 0,334 & $-1,894$ \\
\hline
\end{tabular}

4.2.2 Partição da distância euclidiana, considerando as 15 combinações entre genitores adaptados e não adaptados

A partição das estimativas das distâncias euclidianas em componentes médio, geral e específico (Tabela 17) também foi realizada considerando as 15 distâncias, referentes às combinações nas quais uma das linhagens era adaptada $(1,2,3,4$ ou 5$)$ e a outra não adaptada (6,7 ou 8). Verificou-se que a distância euclidiana geral (DEG) e a distância euclidiana específica (DEE) explicaram $81 \%$ e $19 \%\left(R^{2}\right.$ de 0,81 e 0,19$)$ 
das diferenças entre os valores da distância euclidiana. Portanto, a maior parte da variabilidade medida pela distância euclidiana está contida na DEG. As considerações realizadas para justificar a maior importância do componente geral da distância euclidiana quando consideradas todas as 25 populações são também válidas para este caso.

Os valores DEG mostram que a linhagem 8 é a que possui menos locos em comum com as linhagens adaptadas. Entre as linhagens adaptadas, a 2 é a que apresenta maior número de locos em comum com os genótipos não adaptados.

Tabela 17. Estimativas das distâncias euclidianas gerais e das distâncias euclidianas específicas, considerando a existência de dois grupos de genitores.

\begin{tabular}{ccccc}
\hline & & \multicolumn{3}{c}{ DEE } \\
\cline { 3 - 5 } & DEG & 6 & 7 & 8 \\
\hline$\mu$ & 3,918 & & & \\
1 & $-0,091$ & $-0,101$ & 0,097 & 0,004 \\
2 & $-0,377$ & 0,849 & $-0,522$ & $-0,327$ \\
3 & 0,038 & $-0,305$ & 0,129 & 0,176 \\
4 & 0,334 & $-0,061$ & 0,195 & $-0,134$ \\
5 & 0,096 & $-0,383$ & 0,102 & 0,281 \\
6 & $-0,367$ & & & \\
7 & $-0,505$ & & & \\
8 & 0,872 & & & \\
\hline
\end{tabular}

4.3 Avaliação dos genitores com marcadores moleculares RAPD.

A análise dos oito genitores com os 96 primers permitiu a obtenção de 1139 marcadores RAPD consistentes, sendo 213 polimórficos. A taxa de polimorfismo verificada foi de $18,7 \%$. O número médio de locos amostrado por primer foi 11,87 , e o polimorfismo médio foi de 2,22. A moda do número de locos polimónficos amostrados pelos primers foi 2, com extremos de zero a sete. A Figura 2 mostra o padrão de amplificação obtido com o primer OPA11 e OPA12.

Alguns produtos de amplificação foram observados em apenas uma das concentrações de DNA genômico utilizadas, isto é 40 ou 60 ng. Estes fragmentos de DNA foram considerados inconsistentes e não utilizados nas análises realizadas. Portanto, a utilização de duas concentrações de DNA foi importante para verificar a 
repetibilidade e consistência dos produtos de amplificação. De modo geral, os perfis observados mostraram padrões excelentes de amplificação, permitindo leituras bastante precisas dos géis.
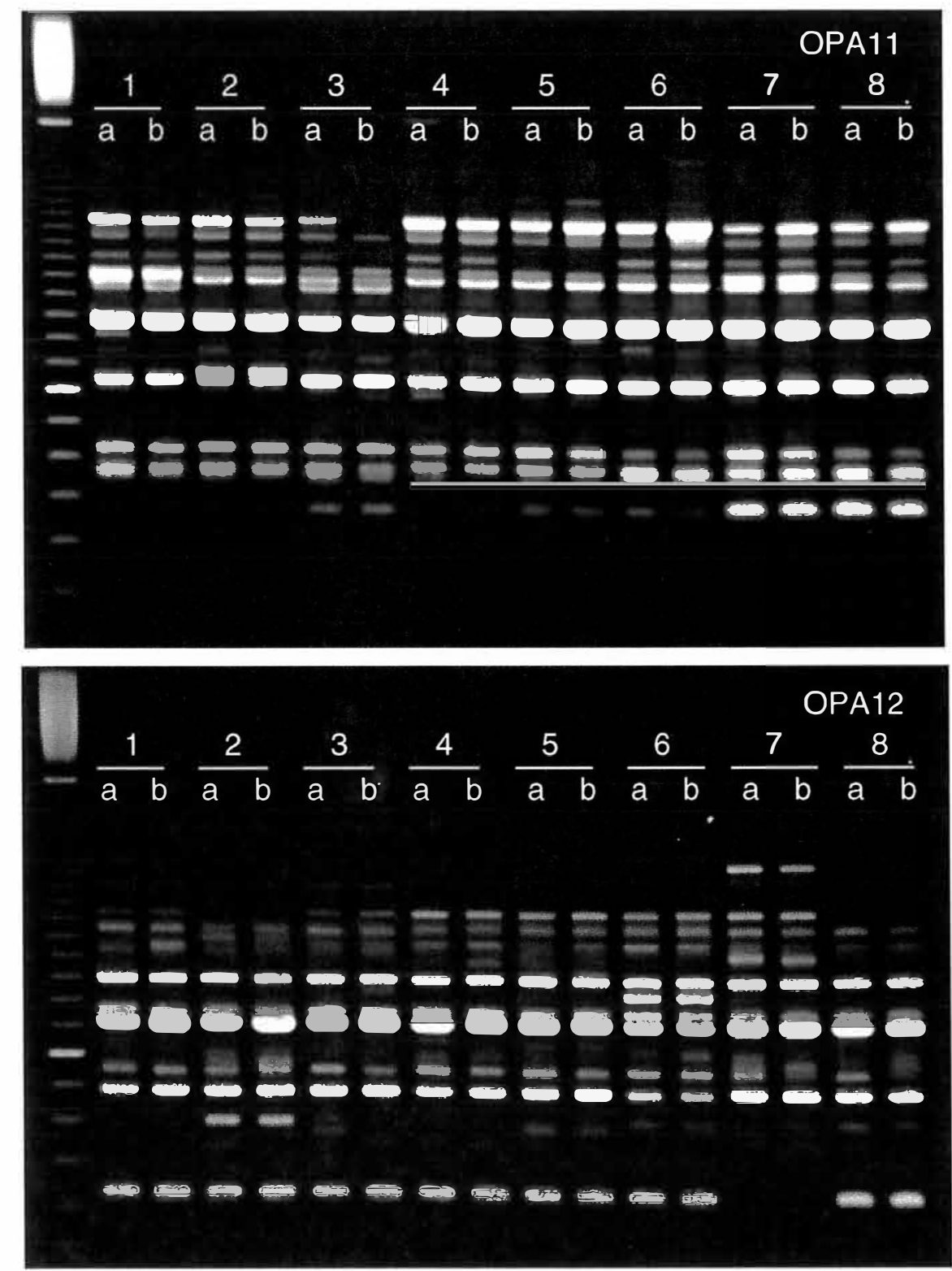

Figura 2. Padrão de amplificação do DNA genômico dos oito genitores utilizando o primer OPA11 e OPA12. 1-Gaúcha; 2- LA-4910-215; 3- OC-79230; 4- BR-80-8858; 5BR-80-14853; 6- Pl-123439 ; 7- Pl-165896 ; 8- Pl-239235. As letras "a" e "b" correspondem à utilização de 40ng e 60ng de DNA genômico, respectivamente. 


\subsubsection{Distância genética entre as oito linhagens}

As estimativas das distâncias genéticas entre os genitores podem ser observadas na Tabela 18. A menor distância verificada foi 0,14 (entre os genótipos 1 e 3) e a maior foi 0,50 (entre 5 e 7 e entre 6 e 7). Os valores observados de distância genética são proporcionais aos obtidos por Vilarinhos et al. (1994), que também trabalharam com linhagens adaptadas e não adaptadas de soja.

Tabela 18. Distâncias genéticas entre os genitores, estimadas a partir das informações fornecidas pelos marcadores RAPD.

\begin{tabular}{cccccccc}
\hline Genitor & 1 & 2 & 3 & 4 & 5 & 6 & 7 \\
\hline 2 & 0,36 & & & & & & \\
3 & 0,14 & 0,34 & & & & & \\
4 & 0,27 & 0,32 & 0,25 & & & & \\
5 & 0,37 & 0,43 & 0,37 & 0,26 & & & \\
6 & 0,44 & 0,45 & 0,43 & 0,41 & 0,43 & & \\
7 & 0,46 & 0,39 & 0,46 & 0,43 & 0,50 & 0,50 & \\
8 & 0,30 & 0,35 & 0,30 & 0,35 & 0,40 & 0,38 & 0,44 \\
\hline
\end{tabular}

A análise de agrupamento mostrou que os genitores adaptados (1, 2, 3, 4 e 5) se agruparam em único cluster, que também contém o genitor não adaptado 8 . Os genitores 6 e 7 não se agruparam, permanecendo isolados (Figura 3). O coeficiente da correlação cofenética foi 0,90 . Este valor mostra um grande ajuste entre a matriz de distâncias genéticas e o dendrograma.

O número de marcadores por primer foi diferente dos verificados em outros estudos utilizando RAPD em soja. Abdelnoor et al. (1995) e Vilarinhos et al. (1994) obtiveram um menor número de produtos de amplificação por reação. Segundo Cruz \& Milach (1998), as condições de estringência das reações RAPD determinam o número de fragmentos amplificados. Como as condições utilizadas neste trabalho foram um pouco diferentes das utilizadas pelos dois autores, o maior número de bandas pode ser atribuído a estringência diferente das reações realizadas neste trabalho $e$ nos realizados por Abdelnoor et al. (1995) e Vilarinhos et al. (1994). 


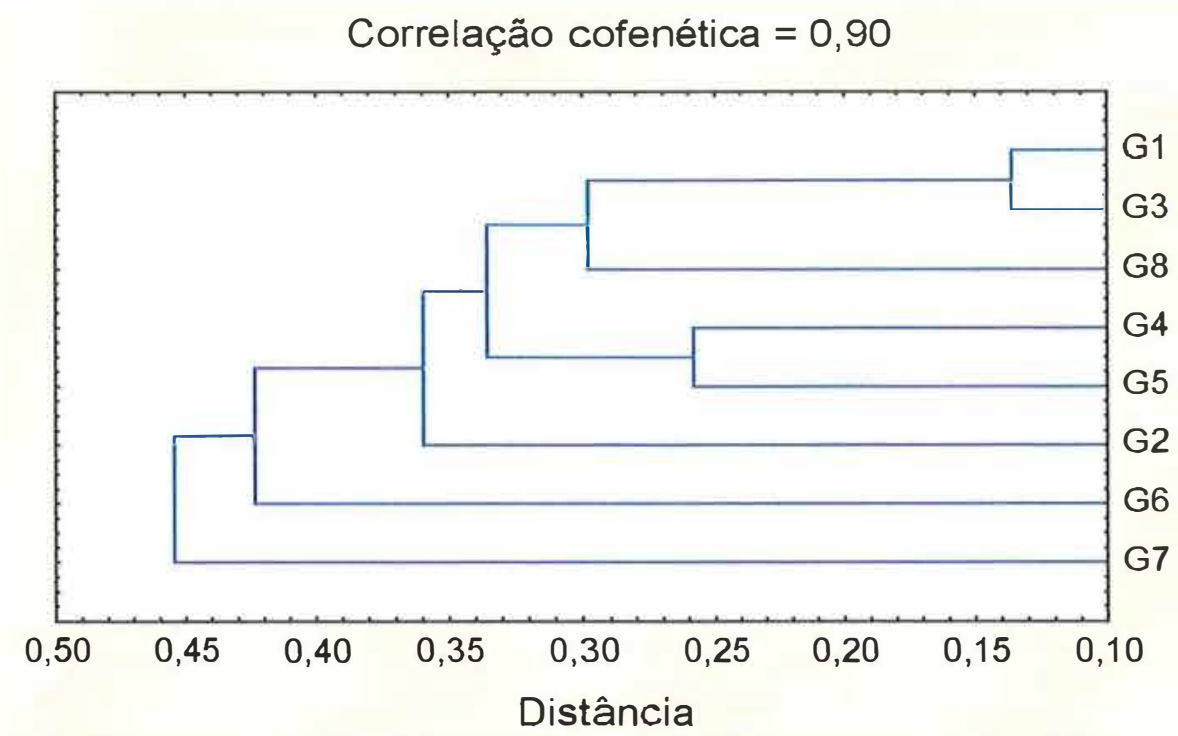

Figura 3 Correlação cofenética e agrupamento dos genitores segundo a análise das distâncias genéticas pelo método UPGMA.

A análise bootstrap permitiu verificar que a precisão das estimativas de distância genética, medida pelo coeficiente de variação médio, aumentou com o número de locos polimórficos. Observa-se na Figura 4 que o coeficiente de variação médio diminuiu com o aumento do tamanho amostral; o menor valor observado foi $5,39 \%$ quando foram utilizados os 213 locos. Também se observou que as reduções são superiores a 0,5\% até o tamanho amostral de 103 locos.

A transformação do coeficiente de variação médio e do tamanho da amostra por logaritmo decimal tornou linear a relação entre as duas variáveis. O coeficiente de correlação calculado entre as duas variáveis transformadas foi próximo a -1 (Figura 5). Caso a equação de regressão apresentada na Figura 5 seja válida para tamanhos amostrais superiores aos obtidos, pode-se estimar que seriam necessários 316,43 locos polimórficos para obter um CV médio de 4,39. Isto indica que as estimativas das distâncias genéticas seriam apenas um pouco mais precisas utilizando um número de marcadores polimónficos muito maior. Portanto, considerou-se que o número de marcadores utilizados foi suficiente para obter estimativas consistentes da distância genética entre os genitores. 


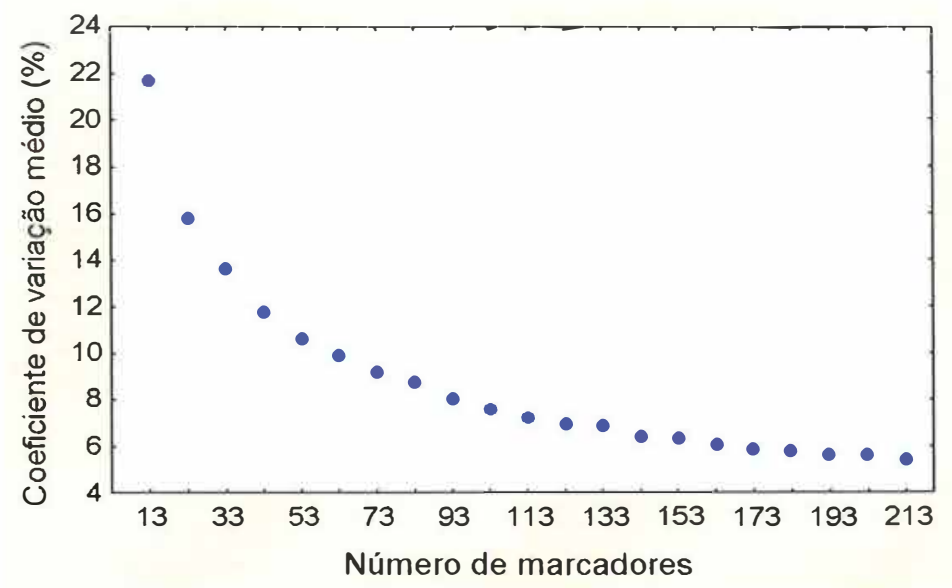

Figura 4. Coeficiente de variação médio da distância genética entre os genitores, de acordo com o número de locos RAPD reamostrados utilizando a técnica bootstrap.

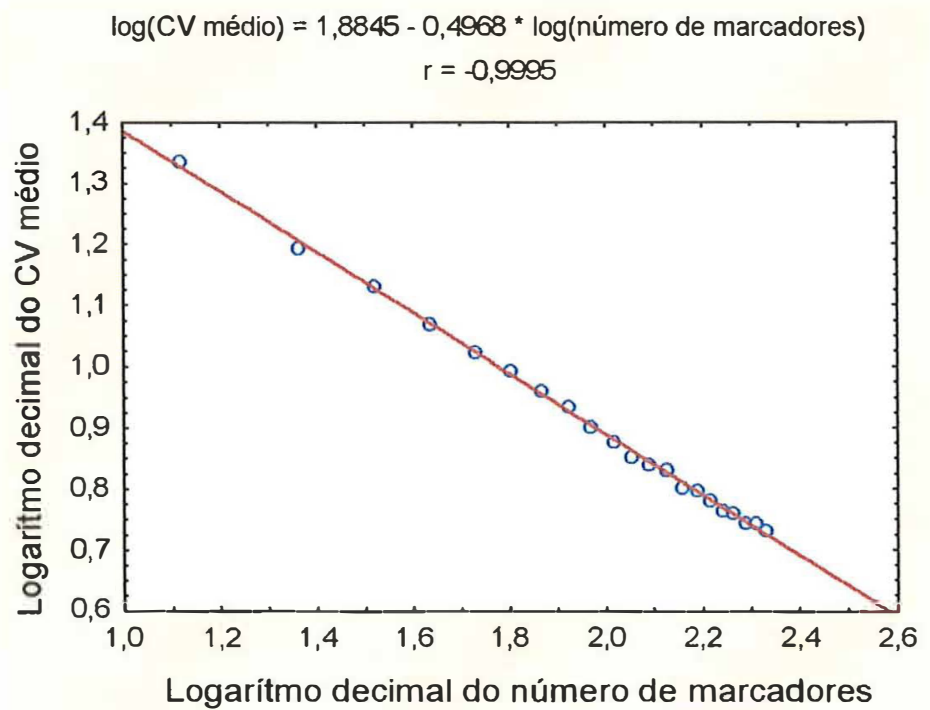

Figura 5. Coeficiente de correlação, equação da reta e coeficiente de variação médio da distância genética entre os genitores de acordo com o número de locos RAPD reamostrados utilizando a técnica bootstrap.

Embora não tenha sido possível levantar a genealogia de todas as linhagens, as informações disponíveis podem ser utilizadas para dar consistência a separação realizada pelos marcadores (Tabela 1). As linhagens não adaptadas 6,7 e 8 foram coletas em países asiáticos diferentes, e portanto devem ser realmente mais distantes. 
Entre as adaptadas, só foi possivel identificar parte da genealogia das linhagens 4 e 5, que apresentam um ancestral comum (Abura). Porém considerando que a base genética das cultivares brasileiras é estreita (Hiromoto \& Vello, 1986), é possível que as genealogias das linhagens adaptadas apresentem mais de um ancestral comum. Adicionalmente, Abdelnoor et al. (1995) mostraram que as distâncias genéticas estimadas por marcadores RAPD entre genótipos adaptados é pequena. Portanto, é esperado que elas apresentem as menores distâncias.

O único resultado não esperado foi aquele observado para a linhagem 8 , que se agrupou junto com as linhagens adaptadas. A princípio, esperava-se que esta linhagem se comportasse como as demais não adaptadas. Contudo, ela apresentou muitos marcadores em comum com as linhagens adaptadas e, em conseqüência, as distâncias foram relativamente pequenas.

4.3.2 Estimativa das distâncias gerais e especificas considerando a existência de um grupo de genitores

A partição das distâncias genéticas mostrou que a DGG (Tabela 19) explica a maior parte da variabilidade da distância genética, com coeficiente de determinação $\left(R^{2}\right)$ igual a 0,74 . A DGE explicou $26 \%$ das diferenças observadas entre as distâncias genéticas. Novamente o componente geral apresentou maior importância do que o componente especifico.

Como já discutido para a distância euclidiana, os valores observados de distância genética apresentaram maior heterogeneidade do que os obtidos por outros autores que realizaram a partição (Melchinger et al., 1990a, Melchinger et al., 1990b, Melchinger et al., 1992). De acordo com Freire Filho (1988), a maior heterogeneidade entre linhagens resulta em maior importância da capacidade geral de combinação. Como a capacidade geral de combinação é correspondente a DGG, as diferenças obtidas em relação à literatura devem ter sido ocasionadas pela maior heterogeneidade existente entre as oito de linhagens analisadas do que entre os genótipos avaliados pelos autores.

Para a combinação de genitores 1 com 3, a importância relativa do componente específico foi mais alta que o componente geral. Observando a Tabela 19, verifica-se 
que esta combinação de linhagens apresenta os menores valores DGE, indicando que o cruzamento entre as duas deve possuir menos locos segregando do que a média dos demais cruzamentos. Contudo este comportamento foi uma exceção, visto que a DGG foi mais importante para a maioria das combinações.

A DGG da linhagem não adaptada 8 foi negativa, da linhagem adaptada 5 foi positiva e da 2 foi igual a zero. Segundo Melchinger et al. (1990) isto indica que uma linhagem não adaptada possui mais alelos em comum com este conjunto de genótipos do que duas linhagens adaptadas. Este resultado contraria os obtidos pela partição da distância euclidiana.

Tabela 19. Estimativas das distâncias genéticas gerais $\left(D G G_{i}\right)$ e especificas $\left(D G E_{i j}\right)$

\begin{tabular}{rrrrrrrrr}
\hline & & \multicolumn{1}{c}{ DGG $_{i j}$} \\
\cline { 3 - 9 } & & 1 & 2 & 3 & 4 & 5 & 6 & 7 \\
\hline$\mu$ & 0,376 & & & & & & & \\
1 & $-0,051$ & & & & & & & \\
2 & 0,001 & 0,035 & & & & & & \\
3 & $-0,059$ & $-0,131$ & 0,020 & & & & & \\
4 & $-0,056$ & $-0,002$ & $-0,002$ & $-0,008$ & & & & \\
5 & 0,023 & 0,018 & 0,028 & 0,031 & $-0,077$ & & & \\
6 & 0,068 & 0,048 & 0,001 & 0,042 & 0,020 & $-0,035$ & & \\
7 & 0,092 & 0,038 & $-0,074$ & 0,051 & 0,020 & 0,012 & $-0,034$ & \\
8 & $-0,018$ & $-0,007$ & $-0,007$ & $-0,004$ & 0,050 & 0,023 & $-0,041$ & $-0,013$ \\
\hline
\end{tabular}

4.3.3 Estimativa das distâncias gerais e especificas considerando a existência de dois grupos de genitores.

A partição da distância genéticas em componentes médio, geral e específico também foram realizadas considerando apenas 15 distâncias, referentes às combinações em que uma das linhagens era adaptada e a outra não adaptada (Tabela 20). Verificou-se que a importância da distância genética geral foi ainda maior do que quando todas as 28 distâncias foram consideradas, possuindo um coeficiente de determinação $\left(R^{2}\right)$ de 0,80 . A distância genética especifica explicou $20 \%$ diferenças observadas entre as distâncias genéticas $\left(R^{2}=0,20\right)$. 
Entre as linhagens adaptadas, apenas a 5 possui DGG positiva. Entre as não adaptadas, a 8 é única que apresenta DGG negativa. Isto indica que o genitor 8 é o que apresenta maior número de locos em comum com os adaptados e que o genitor 5 é o que apresenta menor número de locos iguais aos existentes nos genótipos não adaptados. Estes resultados concordam com os obtidos pela partição da distância genética considerando todas as 28 combinações entre os genótipos. Contudo, diferem dos verificados pela partição da distância euclidiana. Isto indica que a DGG e a DEG são medidas de diversidade diferentes.

Tabela 20. Estimativas das distâncias genéticas gerais dos grupos adaptado não adaptado (DGG) e a distância genética especifica (DGE).

\begin{tabular}{rrrrr}
\hline & & \multicolumn{3}{c}{ DGE } \\
\cline { 3 - 5 } & \multicolumn{1}{c}{ DGG } & \multicolumn{1}{c}{6} & \multicolumn{1}{c}{7} & \multicolumn{1}{c}{8} \\
\hline$\mu$ & 0,407 & & & \\
1 & $-0,008$ & 0,018 & 0,014 & $-0,033$ \\
2 & $-0,009$ & 0,024 & $-0,045$ & 0,021 \\
3 & $-0,013$ & 0,088 & 0,024 & $-0,033$ \\
4 & $-0,009$ & $-0,013$ & $-0,008$ & 0,021 \\
5 & 0,039 & $-0,038$ & 0,014 & 0,024 \\
6 & 0,024 & & & \\
7 & 0,042 & & & \\
8 & $-0,066$ & & & \\
\hline
\end{tabular}

4.4 Dialelo na geração $F_{2}$

4.4.1 Dialelo considerando todas populações

Conforme já descrito no capitulo material e métodos, estas análises correspondem à reavaliação dos dados obtidos por Pimentel (1991) utilizando o modelo I, método 4 de Griffing ao invés do modelo $B$, método 2. As análises para os caracteres produção de grãos e altura das plantas na maturação foram previamente realizadas por Pulcinelli (1997). Elas foram refeitas sem que nenhuma alteração tenha sido realizada. Portanto, as análises dialélicas na geração $F_{2}$ para os caracteres 
produção de grãos e altura das plantas na maturação não são inéditas e os créditos devem ser atribuidos a Pulcinelli (1997).

As análises de variância do dialelo na geração $F_{2}$ (Tabela 21) mostram que os efeitos da capacidade geral de combinação foram significativos para todos os caracteres estudados. A capacidade especifica de combinação foi significativa apenas para os caracteres altura das plantas na maturação e dias para o florescimento.

Segundo Cruz \& Regazzi (1997), os efeitos da capacidade geral de combinação proporcionam informações sobre a concentração de genes predominantemente aditivos. Os efeitos da capacidade específica são medidas dos efeitos gênicos não aditivos. Os autores também consideram que os quadrados médios associados à capacidade geral e especifica podem informar a respeito da importância relativa dos dois componentes de média.

Observando a Tabela 21 percebe-se que o quadrado médio associado às capacidades gerais foram sempre maiores que o quadrado médio da capacidade especifica. As menores diferenças foram verificadas para os caracteres produção de grãos e altura das plantas na maturação, mas mesmos nestes caracteres o quadrado médio associado a capacidade geral é cerca de dez vezes maior que o da capacidade especifica. Portanto os efeitos aditivos são mais importante para a composição da média das populações na geração $F_{2}$.

A maior importância da capacidade geral de combinação parece ser uma regra em estudos realizados em soja. Outros autores tem demonstrado que seus efeitos são geralmente mais importantes para a composição da média do que os efeitos da capacidade específica de combinação em gerações com endogamia incompleta (Bhatade et al., 1977; Paludzyszyn Filho, 1982; Sabbough, 1987; Freire Filho, 1988; Nass, 1989; Pimentel, 1991).

Os valores da capacidade geral de combinação (Tabela 22) mostram que a utilização da linhagem 8 como genitora deu origem às populações mais altas e tardias, enquanto a utilização da linhagem 6 tendeu a gerar populações mais baixas e precoces. Quanto a produção de grãos, as capacidades gerais dos genótipos adaptados foram positivas à exceção da linhagem 1. Entre os genótipos não adaptados as linhagens 6 e 7 apresentaram valores negativos e altos e a linhagem 8 apresentou efeito positivo da capacidade geral de combinação. 
Com relação ao acamamento, as linhagens não adaptadas apresentaram efeitos positivos da capacidade geral de combinação e as linhagens adaptadas valores negativos.

Tabela 21. Resumo da análise de variância da tabela dialélica da geração $F_{2}$, segundo o modelo I de Griffing método 4.

\begin{tabular}{l|cc|cc|cc|cc|cc|cc|}
\hline & \multicolumn{2}{|c|}{ AC } & \multicolumn{2}{|c|}{ AF } & \multicolumn{2}{c|}{ AM } & \multicolumn{2}{c|}{ DF } & \multicolumn{2}{|c}{ DM } & \multicolumn{2}{c}{ PG } \\
\hline F.V. & GL & QM & GL & QM & GL & QM & GL & QM & GL & QM & GL & QM \\
\hline $\mathrm{g}_{\mathrm{i}}$ & 7 & $11,95^{\star \star}$ & 7 & $81,17^{\star \star}$ & 7 & $449,51^{\star \star}$ & 7 & $23,29^{\star \star}$ & 7 & $21,70^{\star \star}$ & 7 & $57,65^{\star \star}$ \\
$\mathrm{s}_{\mathrm{ij}}$ & 19 & $0,88^{1}$ & 19 & 8,23 & 19 & $19,30^{\star}$ & 19 & $0,77^{\star}$ & 19 & 0,97 & 19 & 5,44 \\
Resid. & 228 & $1,17^{1}$ & 228 & 5,48 & 228 & 8,94 & 228 & 0,29 & 228 & 0,59 & 228 & 4,98 \\
\hline
\end{tabular}

AC - Acamamento; AF - Altura das plantas no florescimento; AM - altura das plantas na maturação; DF dias para o florescimento; DM - dias para a maturação; $P G$ - produção de grãos 1. $Q M^{*} 10^{3}$

\subsubsection{Dialelo parcial considerando a existência de dois grupos de genitores}

As análises de variância dos dialelos parciais da geração $F_{2}$ (Tabela 23) mostram que os efeitos das capacidades geral de combinação do grupo de genitores não adaptados foram significativos para todos os caracteres estudados. Os efeitos da capacidade geral do grupo de genitores adaptados não foram significativos apenas para a produção de grãos e para o número de dias para a maturação. Os efeitos da capacidade específica de combinação foram significativos para a altura das plantas na maturação.

Os valores das somas de quadrados mostram que a capacidade geral de combinação dos genitores não adaptados foi o componente mais importante para este conjunto de populações. O quadrado médio associado a este componente foi cerca de dez vezes maior que o associado à capacidade geral do grupo adaptado e vinte vezes maior do que o associado à capacidade específica de combinação. $O$ único caráter onde os valores foram relativamente menores foi acamamento. Portanto, os efeitos aditivos presentes no grupo não adaptado contiveram quase toda a variabilidade existente neste conjunto de populações (Cruz \& Regazzi, 1997). 
Tabela 22. Estimativa dos parâmetros obtida pela análise dialélica da geração $F_{2}$, segundo o modelo 1 de Griffing método 4.

\begin{tabular}{rrrrrrr}
\hline & \multicolumn{1}{c}{$A C$} & \multicolumn{1}{c}{$A M$} & \multicolumn{1}{c}{$A F$} & \multicolumn{1}{c}{ DF } & \multicolumn{1}{c}{ DM } & \multicolumn{1}{c}{$P G$} \\
\hline$\mu$ & 1,4769 & 76,85 & 47,98 & 55,52 & 154,82 & 28,28 \\
$\mathrm{~g}_{1}$ & $-0,0191$ & $-5,80$ & 0,04 & 0,52 & 0,94 & $-1,73$ \\
$\mathrm{~g}_{2}$ & $-0,0314$ & 6,64 & $-2,14$ & $-1,31$ & $-0,14$ & 2,32 \\
$\mathrm{~g}_{3}$ & $-0,0464$ & $-7,56$ & $-1,41$ & $-0,74$ & 0,91 & 2,49 \\
$\mathrm{~g}_{4}$ & $-0,0331$ & $-7,56$ & $-2,87$ & $-0,14$ & 0,76 & 2,83 \\
$\mathrm{~g}_{5}$ & $-0,0341$ & $-2,85$ & 0,90 & $-0,78$ & 0,30 & 2,01 \\
$\mathrm{~g}_{6}$ & 0,0219 & $-6,82$ & $-2,16$ & $-1,44$ & $-3,96$ & $-5,50$ \\
$\mathrm{~g}_{7}$ & 0,0969 & 11,31 & $-0,96$ & $-0,76$ & $-1,21$ & $-3,30$ \\
$\mathrm{~g}_{8}$ & 0,0453 & 12,63 & 8,60 & 4,65 & 2,41 & 0,88 \\
$\mathrm{~s}_{12}$ & $-0,0064$ & $-2,46$ & $-2,45$ & $-0,58$ & $-0,39$ & $-2,37$ \\
$\mathrm{~s}_{13}$ & 0,0286 & $-1,58$ & $-3,97$ & $-0,01$ & $-0,39$ & 2,93 \\
$\mathrm{~s}_{14}$ & $-0,0147$ & $-4,93$ & $-2,07$ & 0,13 & $-0,13$ & $-1,59$ \\
$\mathrm{~s}_{16}$ & $-0,0297$ & 1,43 & 0,90 & 0,44 & 0,35 & $-1,68$ \\
$\mathrm{~s}_{17}$ & 0,0253 & 2,05 & 0,17 & $-0,08$ & 0,39 & 1,36 \\
$\mathrm{~s}_{18}$ & $-0,0031$ & 5,50 & 7,41 & 0,10 & 0,16 & 1,36 \\
$\mathrm{~s}_{23}$ & 0,0309 & $-0,61$ & 1,18 & $-0,38$ & 0,59 & 1,73 \\
$\mathrm{~s}_{24}$ & 0,0276 & 2,22 & 0,56 & 0,02 & 0,26 & 1,95 \\
$\mathrm{~s}_{25}$ & $-0,0014$ & 3,09 & $-0,16$ & 1,53 & $-0,02$ & 0,51 \\
$\mathrm{~s}_{26}$ & 0,0126 & 4,02 & 1,20 & $-0,01$ & $-0,49$ & $-0,53$ \\
$\mathrm{~s}_{27}$ & $-0,0624$ & $-9,24$ & $-0,89$ & $-1,02$ & $-0,66$ & $-2,45$ \\
$\mathrm{~s}_{28}$ & $-0,0008$ & 2,98 & 0,57 & 0,44 & 0,71 & 1,16 \\
$\mathrm{~s}_{34}$ & 0,0126 & $-0,97$ & 0,61 & 0,96 & 0,49 & $-0,78$ \\
$\mathrm{~s}_{35}$ & 0,0236 & $-0,26$ & $-0,34$ & $-0,85$ & 0,10 & $-4,43$ \\
$\mathrm{~s}_{36}$ & $-0,0124$ & 4,96 & 3,48 & $-0,32$ & 0,36 & 1,94 \\
$\mathrm{~s}_{37}$ & $-0,0274$ & 2,32 & 2,14 & $-0,13$ & $-0,52$ & $-1,33$ \\
$\mathrm{~s}_{38}$ & $-0,0558$ & $-3,86$ & $-3,10$ & 0,73 & $-0,63$ & $-0,07$ \\
$\mathrm{~s}_{45}$ & 0,0303 & 1,08 & 0,64 & 0,71 & 1,79 & 2,83 \\
$\mathrm{~s}_{46}$ & $-0,0358$ & $-3,29$ & $-0,72$ & 0,22 & $-1,79$ & $-2,97$ \\
$\mathrm{~s}_{47}$ & $-0,0108$ & 7,30 & 1,95 & $-0,49$ & 0,74 & 1,74 \\
$\mathrm{~s}_{48}$ & $-0,0091$ & $-1,41$ & $-0,97$ & $-1,55$ & $-1,35$ & $-1,18$ \\
$\mathrm{~s}_{56}$ & $-0,0447$ & $-6,42$ & $-3,12$ & $-1,15$ & $-0,34$ & $-0,65$ \\
$\mathrm{~s}_{57}$ & 0,0403 & 2,09 & 2,48 & 0,35 & $-0,53$ & 0,62 \\
$\mathrm{~s}_{58}$ & $-0,0481$ & 0,43 & 0,50 & $-0,60$ & $-1,00$ & 1,13 \\
$\mathrm{~s}_{67}$ & 0,0142 & $-0,78$ & $-1,59$ & 0,65 & 0,19 & 3,17 \\
$\mathrm{~s}_{68}$ & 0,0959 & 0,08 & $-0,16$ & 0,18 & 1,72 & 0,72 \\
$\mathrm{~s}_{78}$ & 0,0209 & $-3,73$ & $-4,26$ & 0,71 & 0,39 & $-3,12$ \\
\hline
\end{tabular}

AC - Acamamento; AF - Altura das plantas no florescimento; AM - altura das plantas na maturação; DF dias para o florescimento; DM - dias para a maturação; PG - produção de grãos

A Tabela 24 mostra que o melhor genitor não adaptado com relação à produção de grãos foi a linhagem 8, a única com capacidade geral positiva. Esta linhagem também foi a que apresentou efeitos de capacidade geral positivos mais altos para 
quase todos os caracteres. Entre os genitores adaptados, a linhagem 1 foi a única que apresentou valores negativos da para a CGC para a produção de grãos.

Tabela 23 Resumo da análise de variância da tabela dialélica parcial da geração $F_{2}$, segundo o modelo I de Griffing método 4, considerando a existência de dois grupos de linhagens genitoras.

\begin{tabular}{|c|c|c|c|c|c|c|c|c|c|c|c|c|}
\hline \multirow[b]{2}{*}{ F.V } & \multicolumn{2}{|r|}{$A C$} & \multicolumn{2}{|r|}{$\overline{A F}$} & \multicolumn{2}{|r|}{$\overline{A M}$} & \multicolumn{2}{|r|}{ DF } & \multicolumn{2}{|r|}{$\overline{D M}$} & \multicolumn{2}{|r|}{$\overline{P G}$} \\
\hline & $G L$ & QM & $G L$ & $Q M$ & GL & $Q M$ & $G L$ & QM & GL & QM & $G L$ & QM \\
\hline $\mathrm{g}_{\mathrm{i}}$ (adap) & 4 & $1,21^{7}$ & 4 & $15,04^{\star}$ & 4 & $79,24^{\star \star}$ & 4 & $2,13^{\star \star}$ & 4 & 1,36 & 4 & 8,08 \\
\hline$g_{j}$ (não) & 2 & $11,01^{\star \star 1}$ & 2 & $181,46^{\star \star}$ & 2 & $632,72^{\star \star}$ & 2 & $56,34^{\star \star}$ & 2 & $50,22^{\star \star}$ & 2 & $74,11^{\star \star}$ \\
\hline$S_{i j}$ & 8 & $1,29^{1}$ & 8 & 3,12 & 8 & $32,80^{\star \star}$ & 8 & 0,57 & 8 & 0,67 & 8 & 3,39 \\
\hline Resíd. & 228 & $1,17^{1}$ & 228 & 5,48 & 228 & 8,94 & 228 & 0,29 & 228 & 0,59 & 228 & 4,98 \\
\hline
\end{tabular}

AC - Acamamento; AF - Altura das plantas no florescimento; AM - altura das plantas na maturação; DF dias para oflorescimento; $D M$ - dias para a maturação; $P G$ - produção de grãos

1. $Q M^{*} 10^{3}$

Tabela 24. Estimativas dos parâmetros obtidas pela análise dialélica parcial na geração $F_{2}$ segundo o modelo I de Griffing método 4 .

\begin{tabular}{lrrrrrr}
\hline & \multicolumn{1}{c}{$\mathrm{AC}$} & \multicolumn{1}{c}{$\mathrm{AM}$} & \multicolumn{1}{c}{$\mathrm{AF}$} & \multicolumn{1}{c}{$\mathrm{DF}$} & \multicolumn{1}{c}{$\mathrm{DM}$} & \multicolumn{1}{c}{$\mathrm{PG}$} \\
\hline$\mu$ & 1.4813 & 79,72 & 49,52 & 55,64 & 154,14 & 27,12 \\
$\mathrm{~g}_{1}$ & 0.0286 & 0,03 & 3,17 & 1,37 & 0,99 & $-2,86$ \\
$\mathrm{~g}_{2}$ & 0,0020 & 8,73 & $-1,56$ & $-0,81$ & $-0,53$ & 0,23 \\
$\mathrm{~g}_{3}$ & -0.0280 & $-3,58$ & $-0,27$ & 0,05 & 0,40 & 1,19 \\
$\mathrm{~g}_{4}$ & -0.0013 & $-3,86$ & $-2,49$ & $-0,05$ & $-0,29$ & 0,55 \\
$\mathrm{~g}_{5}$ & -0.0013 & $-1,32$ & 1,15 & $-0,55$ & $-0,57$ & 0,90 \\
$\mathrm{~g}_{6}$ & -0.0373 & $-12,97$ & $-4,44$ & $-2,22$ & $-3,12$ & $-3,54$ \\
$\mathrm{~g}_{7}$ & 0.0527 & 5,92 & $-2,42$ & $-1,65$ & $-0,10$ & $-0,56$ \\
$\mathrm{~g}_{8}$ & -0.0153 & 7,06 & 6,86 & 3,86 & 3,22 & 4,10 \\
$\mathrm{~s}_{16}$ & -0.0227 & $-1,12$ & $-1,48$ & 0,25 & 0,13 & $-1,35$ \\
$\mathrm{~s}_{17}$ & 0.0173 & $-1,26$ & $-3,02$ & $-0,16$ & $-0,10$ & 0,92 \\
$\mathrm{~s}_{18}$ & 0.0053 & 2,37 & 4,50 & $-0,08$ & $-0,03$ & 0,43 \\
$\mathrm{~s}_{26}$ & 0.0340 & 5,22 & 1,36 & 0,15 & $-0,27$ & 0,75 \\
$\mathrm{~s}_{27}$ & -0.0560 & $-8,81$ & $-1,55$ & $-0,75$ & $-0,70$ & $-1,93$ \\
$\mathrm{~s}_{28}$ & 0.0220 & 3,59 & 0,19 & 0,61 & 0,97 & 1,18 \\
$\mathrm{~s}_{36}$ & 0.0240 & 4,27 & 3,09 & $-0,45$ & 0,70 & 2,43 \\
$\mathrm{~s}_{37}$ & -0.0060 & 0,86 & 0,93 & $-0,15$ & $-0,45$ & $-1,60$ \\
$\mathrm{~s}_{38}$ & -0.0180 & $-5,14$ & $-4,02$ & 0,61 & $-0,25$ & $-0,83$ \\
$\mathrm{~s}_{46}$ & -0.0127 & $-3,70$ & $-0,35$ & 0,79 & $-0,92$ & $-1,49$ \\
$\mathrm{~s}_{47}$ & -0.0027 & 6,12 & 1,49 & 0,19 & 1,35 & 2,45 \\
$\mathrm{~s}_{48}$ & 0.0153 & $-2,41$ & $-1,14$ & $-0,97$ & $-0,43$ & $-0,96$ \\
$\mathrm{~s}_{56}$ & -0.0227 & $-4,67$ & $-2,63$ & $-0,72$ & 0,36 & $-0,34$ \\
$\mathrm{~s}_{57}$ & 0.0473 & 3,08 & 2,16 & 0,89 & $-0,10$ & 0,16 \\
$\mathrm{~s}_{58}$ & -0.0247 & 1,59 & 0,47 & $-0,16$ & $-0,26$ & 0,18 \\
\hline
\end{tabular}

$A C$ - Acamamento; AF - Altura das plantas no florescimento; AM - altura das plantas na maturação; DF - dias para o florescimento; DM - dias para a maturação; PG - produção de grãos 
4.5 Análise de variância das populações endogâmicas

As análises de variância das populações mostraram que as populações diferiram em todos os caracteres (Tabela 25).

Para os caracteres produção de grãos e altura das plantas na maturação, as análises das gerações $F_{2: n}$ já haviam sido realizadas por Pulcinelli (1997), mas não as análises conjuntas. Os resultados obtidos mostraram que as populações foram diferentes em ambos os caracteres em todas as gerações. Os coeficientes de variação ficaram entre $3,41 \%$ e 5,35\% para a altura das plantas na maturação e entre $12,56 \%$ e $7,71 \%$ para produção de grãos.

Para o caráter dias para a maturação, as populações foram significativamente diferentes na avaliação realizada em $F_{2: 11}$ e na análise conjunta. Em $F_{2: 9}$ as populações não diferiram entre si. Os coeficientes de variação foram baixos, não chegando a $1 \%$.

As análises de variância ao nível das populações para os caracteres altura das plantas no florescimento e dias para o florescimento permitiram verificar que as populações apresentaram diferenças significativas em todas as gerações e na análise conjunta. A interpretação dos coeficientes de variação permite inferir que os experimentos apresentaram boa precisão experimental, à exceção das avaliações realizadas no caráter altura das plantas no florescimento na geração $F_{2: 10}$, que apresentou um coeficiente de variação considerado alto para o caráter $(11,82 \%)$.

Do mesmo modo que na análise dos genitores, as notas atribuídas para avaliar o acamamento das parcelas não apresentou distribuição normal. Para que distribuição se aproxima-se da normal foi realizada a transformação dos dados por $\sqrt{x+1}$. Após as transformações, as análises de variância que mostraram que as populações diferiram na análise conjunta e na geração $F_{2: 8}$. $\dot{E}$ provável que a ausência de diferenças entre as populações em $F_{2: 9}$ seja devido ao valor relativamente alto do coeficiente de variação do experimento feito para avaliar o acamamento nesta geração.

As análises conjunta mostraram que a interação das populações com os anos foi significativa apenas para a altura das plantas na maturação. Isto indica que os ambientes presentes nos anos em que as populações foram avaliadas provocaram respostas desiguais por parte das populações para a altura das plantas (Cruz \& 
Tabela 25. Resumo das análises de variância das populações para os caracteres altura das plantas na maturação* $(A M)$, produção de grãos* $(P G)$, dias para a maturação (DM), altura das plantas no florescimento (AF), dias para o florescimento (DF) e acamamento transformado por $\sqrt{x+1}(A C)$, nos quatro anos de avaliação e análise conjunta.

\begin{tabular}{|c|c|c|c|c|c|c|c|c|c|c|c|}
\hline \multirow[b]{2}{*}{ Caráter } & \multirow[b]{2}{*}{ F. V. } & \multicolumn{2}{|r|}{$F_{2: 8}$} & \multicolumn{2}{|r|}{$F_{2: 9}$} & \multicolumn{2}{|r|}{$\mathrm{F}_{2: 10}$} & \multicolumn{2}{|r|}{$F_{2: 11}$} & \multicolumn{2}{|r|}{ Conjunta } \\
\hline & & $G L$ & $\overline{Q M}$ & $G L$ & QM & $G$ & $\overline{Q M}$ & $G L$ & QM & $G$ & $Q M$ \\
\hline \multirow{6}{*}{$A M$} & Pop. (aj.) & 24 & $223,18^{\star \star}$ & 24 & $323,72^{\star \star}$ & 24 & $184,56^{\star \star}$ & 24 & $255,67^{\star \star}$ & 24 & $407,89^{\star \star}$ \\
\hline & Pop. $x$ anos & & & & & & & & & 72 & $13,39^{\star \star}$ \\
\hline & Erro intrabl. & 36 & 5,97 & 16 & 10,05 & 36 & 17,09 & 36 & 9,64 & & \\
\hline & Média & & 73,67 & & 84,55 & & 77,21 & & 66,33 & & 75,44 \\
\hline & CV (efetivo) & & 3,41 & & 4,01 & & 5,35 & & 4,83 & & 4,45 \\
\hline & Erro efetivo & & 6,32 & & 11,50 & & 17,09 & & 10,25 & 124 & 11,26 \\
\hline \multirow{6}{*}{$P G$} & Pop. (aj.) & 24 & $6018,73^{\star \star}$ & 24 & $2837,24^{\star \star}$ & 24 & $3559,21^{\star \star}$ & 24 & $2606,97^{\star \star}$ & 24 & $5818,06^{\star \star}$ \\
\hline & Pop. $x$ anos & & & & & & & & & 72 & 389,00 \\
\hline & Erro intrabl. & 36 & 447,33 & 16 & 190,07 & 36 & 275,75 & 36 & 82,24 & & \\
\hline & Média & & 259,03 & & 209,98 & & 154,33 & & 141,81 & & 191,29 \\
\hline & CV (efetivo) & & 8,99 & & 7,12 & & 11,41 & & 6,91 & & 9,12 \\
\hline & Erro efetivo & & 541,86 & & 223,83 & & 310,62 & & 96,29 & 124 & 304,33 \\
\hline \multirow{6}{*}{ DM } & Pop. (aj.) & & & 24 & 2,07 & & & 24 & $3,00^{\star \star}$ & 24 & $1,91^{*}$ \\
\hline & Pop. $x$ anos & & & & & & & & & 24 & 0,61 \\
\hline & Erro intrabl. & & & 16 & 1,14 & & & 36 & 0,70 & & \\
\hline & Média & & & & 131,50 & & & & 127,26 & & 129,38 \\
\hline & CV (efetivo) & & & & 0,91 & & & & 0,66 & & 0,75 \\
\hline & Erro efetivo & & & & 1,44 & & & & 0,70 & 52 & 0,93 \\
\hline \multirow{6}{*}{$A F$} & Pop. (aj.) & & & 24 & $78,35^{\star \star}$ & 24 & $172,89^{\star \star}$ & 24 & $51,97^{\star \star}$ & 24 & $101,27^{\star \star}$ \\
\hline & Pop. $x$ anos & & & & & & & & & 24 & 9,57 \\
\hline & Erro intrabl. & & & 16 & 10,66 & 36 & 44,84 & 36 & 4,35 & & \\
\hline & Média & & & & 59,71 & & 62,30 & & 46,85 & & 56,29 \\
\hline & CV (efetivo) & & & & 5,77 & & 11,82 & & 4,70 & & 9,14 \\
\hline & Erro efetivo & & & & 11,85 & & 54,62 & & 4,84 & 88 & 26,48 \\
\hline \multirow{6}{*}{ DF } & Pop. (aj.) & & & 24 & $13,30^{\star \star}$ & 24 & $24,43^{\star \star}$ & 24 & $17,16^{\star \star}$ & 24 & $21,28^{\star \star}$ \\
\hline & Pop. $x$ anos & & & & & & & & & 48 & 0,91 \\
\hline & Erro intrabl. & & & 16 & 0,29 & 36 & 4,83 & 36 & 0,45 & & \\
\hline & Média & & & & 59,68 & & 52,06 & & 51,52 & & 54,42 \\
\hline & CV (efetivo) & & & & 1,00 & & 5,98 & & 4,63 & & 2,97 \\
\hline & Erro efetivo & & & & 0,35 & & 5,80 & & 0,45 & :88 & 2,62 \\
\hline \multirow{6}{*}{$A C^{1}$} & Pop. (aj.) & 24 & $7,10^{\star \star}$ & 24 & 5,48 & & & & & 24 & $4,66^{\star}$ \\
\hline & Pop. $x$ anos & & & & & & & & & 24 & 1,20 \\
\hline & Erro intrabl. & 36 & 0,94 & 16 & 5,15 & & & & & & \\
\hline & Média & & 1,83 & & 1,81 & & & & & & 1,82 \\
\hline & CV (efetivo) & & 5,46 & & 13,53 & & & & & & 9,52 \\
\hline & Erro efetivo & & 1,08 & & 6,03 & & & & & 52 & 2,60 \\
\hline
\end{tabular}


Regazzi, 1997). Portanto, a avaliação em apenas um ano seria suficiente para classificar as populações quanto a todos os caracteres, a exceção da altura das plantas na maturação.

Observando a Tabela 26, verifica-se que o método Scott \& Knott (1974) agrupou as populações em seis grupos nas análises individuais e em sete grupos na análise conjunta para o caráter altura das plantas na maturação. Existiu uma forte tendência das populações serem mais baixas quando a linhagem 6 foi utilizada como genitora. Já a utilização da linhagem 8 tendeu a aumentar a altura das populações. Para o caráter dias para a maturação, as populações foram agrupadas em quatro grupos na geração $F_{2: 11}$ e em dois na análise conjunta. As diferenças encontradas no teste $F$ e na análise de agrupamento Scott e Knott (1974) somente foram possíveis devido as altas precisões experimentais, visto que a duração média do ciclo das populações foi muito semelhante.

A análise de agrupamento mostrou que as populações originadas de cruzamentos em que participaram genitores não adaptados tenderam a permanecer nos grupos de menores médias no caráter produção de grãos (Tabela 27). O genitor 6 foi o que apresentou pior desempenho, com quase todas as populações pertencendo ao grupo de menor média. Os genitores 3 e 4 foram os que produziram populações com melhor desempenho relativo.

Duas populações nas quais a linhagem 8 foi utilizada como genitora foram agrupadas entre as populações mais produtivas na análise conjunta ( $3 \times 8$ e $4 \times 8$ ). 0 bom desempenho de algumas populações formadas a partir deste genótipo não adaptado já haviam sido verificadas por Prado (1999), Gieco (1997) e Pucinelli (1997). Como esta linhagem não apresentou produção alta nos experimentos realizados para avaliar as linhagens genitoras, isto mostra que nem sempre o desempenho per se do genitor é suficiente para explicar o comportamento da média das populações.

Ainda observando a Tabela 27, verifica-se que a maior quantidade de acamamento foi verificada nas populações em que os genitores 7 e 8 foram utilizados. Também é possivel observar que todas as notas médias foram acima de um, mostrando que nenhuma população apresentou todas as plantas eretas. 
Tabela 26. Médias ajustadas das populações endogâmicas para os caracteres altura das plantas na maturação (AM), em centímetros, e dias para a maturação (DM), em dias.

\begin{tabular}{|c|c|c|c|c|c|c|c|c|}
\hline \multirow[b]{2}{*}{ População } & \multicolumn{5}{|c|}{$A M$} & \multicolumn{3}{|c|}{$D M$} \\
\hline & $\mathrm{F} 2: 8$ & F2:9 & $F 2: 10$ & F2: 11 & Conjunta & $F_{29}$ & $F_{2: 11}$ & Conjunta \\
\hline $1 \times 2$ & $77,13 D^{1}$ & $86,22 \mathrm{C}$ & $86,50 \mathrm{C}$ & $70,27 \mathrm{C}$ & $80,03 \mathrm{C}$ & 131,78 & $128,55 \mathrm{~A}$ & $130,16 \mathrm{~A}$ \\
\hline $1 \times 3$ & $63,14 \mathrm{~F}$ & $75,17 \mathrm{D}$ & $70,33 \mathrm{D}$ & $62,44 \mathrm{E}$ & $67,77 \mathrm{~F}$ & 131,67 & $128,63 \mathrm{~A}$ & $130,15 \mathrm{~A}$ \\
\hline $1 \times 4$ & $59,48 \mathrm{~F}$ & $58,60 \mathrm{~F}$ & $65,26 \mathrm{E}$ & $55,32 \mathrm{~F}$ & $59,67 \mathrm{G}$ & 130,88 & $127,03 \mathrm{C}$ & $128,95 \mathrm{~B}$ \\
\hline $1 \times 6$ & $60,25 \mathrm{~F}$ & $67,01 \mathrm{~F}$ & $65,17 \mathrm{E}$ & $50,83 \mathrm{~F}$ & $60,82 \mathrm{G}$ & 130,58 & $127,23 \mathrm{~B}$ & $128,91 \mathrm{~B}$ \\
\hline $1 \times 7$ & $74,00 \mathrm{D}$ & $86,51 \mathrm{C}$ & $79,92 \mathrm{C}$ & $68,08 \mathrm{D}$ & $77,13 \mathrm{D}$ & 130,33 & $127,28 \mathrm{~B}$ & $128,81 \mathrm{~B}$ \\
\hline $1 \times 8$ & $75,70 \mathrm{D}$ & $89,69 \mathrm{C}$ & $81,33 \mathrm{C}$ & $65,84 \mathrm{D}$ & $78,14 \mathrm{D}$ & 133,04 & $128,77 \mathrm{~A}$ & $130,91 \mathrm{~A}$ \\
\hline $2 \times 3$ & $76,54 \mathrm{D}$ & $84,02 \mathrm{C}$ & $78,17 \mathrm{C}$ & $66,49 \mathrm{D}$ & $76,30 \mathrm{D}$ & 132,83 & 127,27 B & $130,05 \mathrm{~A}$ \\
\hline $2 \times 4$ & $80,85 \mathrm{C}$ & $93,70 \mathrm{~B}$ & $81,95 \mathrm{C}$ & $78,26 \mathrm{~B}$ & $83,69 \mathrm{C}$ & 133,35 & $127,48 \mathrm{~B}$ & $130,42 \mathrm{~A}$ \\
\hline $2 \times 5$ & $79,44 \mathrm{C}$ & $85,62 \mathrm{C}$ & $75,15 \mathrm{D}$ & $71,03 \mathrm{C}$ & $77,81 \mathrm{D}$ & 132,84 & $127,48 \mathrm{~B}$ & $130,16 \mathrm{~A}$ \\
\hline $2 \times 6$ & $75,49 \mathrm{D}$ & $91,78 \mathrm{~B}$ & $79,21 \mathrm{C}$ & $66,28 \mathrm{D}$ & $78,19 \mathrm{D}$ & 130,47 & $125,30 \mathrm{D}$ & $127,88 \mathrm{~B}$ \\
\hline $2 \times 8$ & $97,89 \mathrm{~A}$ & $115,2 \mathrm{~A}$ & $98,81 \mathrm{~A}$ & $92,21 \mathrm{~A}$ & $101,03 \mathrm{~A}$ & 132,46 & $129,18 \mathrm{~A}$ & $130,82 \mathrm{~A}$ \\
\hline $3 \times 5$ & $64,06 \mathrm{~F}$ & $71,63 \mathrm{E}$ & $67,42 \mathrm{E}$ & $60,60 \mathrm{E}$ & $65,93 \mathrm{~F}$ & 132,42 & $127,27 \mathrm{~B}$ & $129,85 \mathrm{~A}$ \\
\hline $3 \times 6$ & $67,87 \mathrm{E}$ & $71,57 \mathrm{E}$ & $70,75 \mathrm{D}$ & 56,2 & 6 & 131,01 & $125,85 \mathrm{D}$ & $128,43 \mathrm{~B}$ \\
\hline $3 \times 7$ & $69,89 \mathrm{E}$ & $85,27 \mathrm{C}$ & $78,99 \mathrm{C}$ & $64,22 \mathrm{E}$ & $74,59 \mathrm{D}$ & 131,83 & $128,33 \mathrm{~A}$ & $130,08 \mathrm{~A}$ \\
\hline $3 \times 8$ & $78,90 \mathrm{C}$ & $99,13 \mathrm{~B}$ & $82,52 \mathrm{C}$ & $74,67 \mathrm{C}$ & $83,81 \mathrm{C}$ & 131,73 & $128,26 \mathrm{~A}$ & $130,00 \mathrm{~A}$ \\
\hline $4 \times 5$ & $66,27 E$ & $70,16 \mathrm{E}$ & $70,17 \mathrm{D}$ & $58,48 \mathrm{E}$ & $66,27 \mathrm{~F}$ & 134,12 & $126,97 \mathrm{C}$ & $130,54 \mathrm{~A}$ \\
\hline $4 \times 6$ & $60,20 \mathrm{~F}$ & $64,78 \mathrm{~F}$ & $64,17 \mathrm{E}$ & $52,37 \mathrm{~F}$ & $60,38 \mathrm{G}$ & 131,49 & $126,47 \mathrm{C}$ & $128,98 \mathrm{~B}$ \\
\hline $4 \times 7$ & $80,43 \mathrm{C}$ & $91,04 \mathrm{~B}$ & $82,75 \mathrm{C}$ & $71,29 \mathrm{C}$ & $81,38 \mathrm{C}$ & 131,48 & $126,65 \mathrm{C}$ & $129,07 \mathrm{~B}$ \\
\hline $4 \times 8$ & $83,14 \mathrm{C}$ & $92,84 \mathrm{~B}$ & $84,00 \mathrm{C}$ & $72,71 \mathrm{C}$ & $83,17 \mathrm{C}$ & 131,75 & $127,95 \mathrm{C}$ & $129,85 \mathrm{~A}$ \\
\hline $5 \times 6$ & $66,45 \mathrm{E}$ & $71,16 \mathrm{E}$ & $67,58 \mathrm{E}$ & $55,64 \mathrm{~F}$ & $65,21 \mathrm{~F}$ & 130,04 & $125,48 \mathrm{D}$ & $127,76 \mathrm{~B}$ \\
\hline $5 \times 7$ & $67,69 \mathrm{E}$ & $77,23 \mathrm{D}$ & $74,25 \mathrm{D}$ & $66,04 \mathrm{D}$ & $71,30 \mathrm{E}$ & 129,48 & $125,35 \mathrm{D}$ & $127,41 \mathrm{~B}$ \\
\hline $5 \times 8$ & $77,85 \mathrm{C}$ & $93,97 \mathrm{~B}$ & $79,42 \mathrm{C}$ & $70,76 \mathrm{C}$ & $80,50 \mathrm{C}$ & 131,24 & $127,43 \mathrm{~B}$ & $129,34 \mathrm{~B}$ \\
\hline $6 \times 7$ & $72,53 \mathrm{D}$ & $80,83 \mathrm{D}$ & $74,34 \mathrm{D}$ & $59,64 \mathrm{E}$ & $71,83 \mathrm{E}$ & 130,06 & $126,68 \mathrm{C}$ & $128,37 \mathrm{~B}$ \\
\hline $6 \times 8$ & $79,41 \mathrm{C}$ & 96,74 B & $82,59 \mathrm{C}$ & $65,27 \mathrm{D}$ & $81,00 \mathrm{C}$ & 130,10 & $126,90 \mathrm{C}$ & $128,50 \mathrm{~B}$ \\
\hline $7 \times 8$ & $87,01 \mathrm{~B}$ & $113,89 \mathrm{~A}$ & $89,43 \mathrm{~B}$ & $83,14 \mathrm{~B}$ & $93,37 \mathrm{~B}$ & 130,43 & $127,80 \mathrm{~B}$ & $129,11 \mathrm{~B}$ \\
\hline
\end{tabular}


Tabela 27. Médias ajustadas das populações endogâmicas para os caracteres produção de grãos (PG), em gramas por parcela, e acamamento (AC).

\begin{tabular}{|c|c|c|c|c|c|c|c|c|}
\hline \multirow[b]{2}{*}{ População } & \multicolumn{5}{|c|}{$P G$} & \multicolumn{3}{|c|}{$A C$} \\
\hline & $F_{2 \cdot 8}$ & $F_{2: 9}$ & $F_{2 \cdot 10}$ & $F_{2 \cdot 11}$ & Conjunta & $F_{2.8}$ & $F_{29}$ & Conjunta \\
\hline $1 \times 2$ & $247,66 D^{1}$ & $243,90 \mathrm{~A}$ & $193,51 \mathrm{~A}$ & $150,88 \mathrm{C}$ & $208,99 \mathrm{~B}$ & $1,86 \mathrm{C}$ & 1,86 & $1,86 \mathrm{~B}$ \\
\hline $1 \times 3$ & $279,00 \mathrm{C}$ & $263,22 \mathrm{~A}$ & $200,62 A$ & $182,65 \mathrm{~B}$ & $231,37 \mathrm{~A}$ & $1,66 \mathrm{C}$ & 2,06 & $1,86 \mathrm{~B}$ \\
\hline $1 \times 4$ & $305,33 \mathrm{C}$ & $245,91 \mathrm{~A}$ & $231,88 \mathrm{~A}$ & $187,82 \mathrm{~A}$ & $242,73 \mathrm{~A}$ & $1,66 \mathrm{C}$ & 2,42 & $2,03 \mathrm{~B}$ \\
\hline $1 \times 6$ & $136,58 E$ & $151,53 \mathrm{C}$ & $101,56 \mathrm{D}$ & $88,03 E$ & $119,42 \mathrm{C}$ & $1,99 \mathrm{C}$ & 2,35 & $2,17 \mathrm{~B}$ \\
\hline $1 \times 7$ & $236,88 D$ & $159,30 \mathrm{C}$ & $112,73 \mathrm{D}$ & $112,70 \mathrm{D}$ & $155,40 \mathrm{C}$ & $3,20 \mathrm{~A}$ & 2,24 & $2,72 \mathrm{~A}$ \\
\hline $1 \times 8$ & $267,01 \mathrm{C}$ & $181,33 \mathrm{C}$ & $159,88 \quad B$ & $146,86 \mathrm{C}$ & $188,77 \mathrm{~B}$ & $2,24 \mathrm{C}$ & 1,22 & $1,69 \mathrm{~B}$ \\
\hline $2 \times 3$ & $293,20 \mathrm{C}$ & $257,42 \mathrm{~A}$ & $202,77 \mathrm{~A}$ & $174,51 \mathrm{~B}$ & $231,98 \mathrm{~A}$ & $1,92 \mathrm{C}$ & 1,40 & $1,66 \mathrm{~B}$ \\
\hline $2 \times 4$ & $296,27 \mathrm{C}$ & $255,09 \mathrm{~A}$ & $160,29 \mathrm{~B}$ & $176,10 \mathrm{~B}$ & $221,94 \mathrm{~A}$ & $1,99 \mathrm{C}$ & 1,79 & $1,89 \mathrm{~B}$ \\
\hline $2 \times 5$ & $276,00 \mathrm{C}$ & $247,32 \mathrm{~A}$ & $137,80 \mathrm{C}$ & $162,86 \mathrm{C}$ & $205,99 \mathrm{~B}$ & $2,03 \mathrm{C}$ & 2,17 & $2,10 \mathrm{~B}$ \\
\hline $2 \times 6$ & $165,79 E$ & $193,52 B$ & $115,97 \mathrm{D}$ & $105,42 E$ & $145,18 \mathrm{C}$ & $2,57 \mathrm{~B}$ & 2,17 & $2,35 \mathrm{~B}$ \\
\hline $2 \times 8$ & $275,34 \mathrm{C}$ & $190,97 \mathrm{~B}$ & $147,73 \mathrm{C}$ & $154,49 \mathrm{C}$ & $192,13 \mathrm{~B}$ & $3,00 \mathrm{~B}$ & 2,76 & $2,88 \mathrm{~A}$ \\
\hline $3 \times 5$ & $288,23 \mathrm{C}$ & $272,46 \mathrm{~A}$ & $178,00 \quad B$ & $197,65 \mathrm{~A}$ & $234,09 \mathrm{~A}$ & $1,40 \mathrm{C}$ & 2,35 & $1,86 \mathrm{~B}$ \\
\hline $3 \times 6$ & $233,99 \mathrm{D}$ & $194,73 \mathrm{~B}$ & $173,02 B$ & $127,21 \quad D$ & $182,24 \mathrm{C}$ & $1,79 \mathrm{C}$ & 2,17 & $1,96 \mathrm{~B}$ \\
\hline $3 \times 7$ & $258,27 \mathrm{C}$ & $211.13 \mathrm{~B}$ & $164,04 \mathrm{~B}$ & $132,97 \mathrm{D}$ & $191,60 \mathrm{~B}$ & $2,46 \mathrm{~B}$ & 1,79 & $2,13 \mathrm{~B}$ \\
\hline $3 \times 8$ & $316,50 \mathrm{~B}$ & $230,59 \mathrm{~A}$ & $206,76 \mathrm{~A}$ & $173,30 \mathrm{~B}$ & $231,79 \mathrm{~A}$ & $2,46 \mathrm{~B}$ & 1,76 & $2,10 \mathrm{~B}$ \\
\hline $4 \times 5$ & $373,85 \mathrm{~A}$ & $278,18 \mathrm{~A}$ & $213,21 \mathrm{~A}$ & $196,13 \mathrm{~A}$ & $265,34 \mathrm{~A}$ & $1,59 \mathrm{C}$ & 1,69 & $1,66 \mathrm{~B}$ \\
\hline $4 \times 6$ & $196,82 \mathrm{D}$ & $155,66 \mathrm{C}$ & $125,96 \mathrm{C}$ & $116,89 \mathrm{D}$ & $148,83 \mathrm{C}$ & $1,86 \mathrm{C}$ & 1,99 & $1,92 \mathrm{~B}$ \\
\hline $4 \times 7$ & $302,60 \mathrm{C}$ & $210,54 \mathrm{~B}$ & $146,40 \mathrm{C}$ & $124,20 \mathrm{D}$ & $195,93 \mathrm{~B}$ & $2,50 \mathrm{~B}$ & 2,28 & $2,39 \mathrm{~B}$ \\
\hline $4 \times 8$ & $320,03 \mathrm{~B}$ & $231,88 A$ & $175,46 \quad B$ & $162,98 \mathrm{C}$ & $222,59 \mathrm{~A}$ & $2,76 \mathrm{~B}$ & 3,12 & $2,92 \mathrm{~A}$ \\
\hline $5 \times 6$ & $218,17 \mathrm{D}$ & $208,12 B$ & $137,32 \mathrm{C}$ & $116,64 \mathrm{D}$ & $170,06 \mathrm{C}$ & $2,13 \mathrm{C}$ & 2,24 & $2,17 \mathrm{~B}$ \\
\hline $5 \times 7$ & $224,34 \mathrm{D}$ & $173,58 \mathrm{C}$ & $106,95 \mathrm{D}$ & $118,55 \mathrm{D}$ & $155,86 \mathrm{C}$ & $2,84 \mathrm{~B}$ & 2,72 & $2,76 \mathrm{~A}$ \\
\hline $5 \times 8$ & $283,65 \mathrm{C}$ & $201,29 \mathrm{~B}$ & $137,46 \mathrm{C}$ & $143,34 \mathrm{C}$ & $191,44 \mathrm{~B}$ & $2,88 \mathrm{~B}$ & 3,84 & $3,37 \mathrm{~A}$ \\
\hline $6 \times 7$ & $213,96 \mathrm{D}$ & $175,72 \mathrm{C}$ & $106,84 D$ & $86,92 E$ & $145,86 \mathrm{C}$ & $2,84 \mathrm{~B}$ & 2,72 & $2,76 \mathrm{~A}$ \\
\hline $6 \times 8$ & $239,18 \mathrm{D}$ & $174,83 \mathrm{C}$ & $112,34 \mathrm{D}$ & $111,79 \mathrm{D}$ & $159,54 \mathrm{C}$ & $3,71 \mathrm{~A}$ & 3,41 & $3,58 \mathrm{~A}$ \\
\hline $7 \times 8$ & $227,00 \mathrm{D}$ & $141,19 \mathrm{C}$ & $109,77 \mathrm{D}$ & $94,31 \mathrm{E}$ & $143,07 \mathrm{C}$ & $4,02 \mathrm{~A}$ & 2,96 & $3,45 \mathrm{~A}$ \\
\hline
\end{tabular}

1. Médias seguidas de letras diferentes pertencem a grupos distintos segundo a análise de agrupamento de Scott \& Knott 
A análise da Tabela 28 permite observar que as populações foram divididas em apenas dois grupos pelo método de agrupamento de Scott \& Knott 1974) na análise conjunta para os caracteres altura no florescimento e dias para o florescimento. As populações que foram alocadas nos grupos com maior altura no florescimento e maior duração do periodo vegetativo sempre foram formadas utilizando a linhagem 8 . Este resultado concorda com a análise dos pais, onde se verificou que a linhagem 8 é a que apresenta a maior média para ambos os caracteres.

Tabela 28. Médias ajustadas das populações endogâmicas para os caracteres altura das plantas no florescimento (AF), em centímetros, e dias para o florescimento (DF), em dias.

\begin{tabular}{|c|c|c|c|c|c|c|c|c|}
\hline \multirow[b]{2}{*}{ População } & \multicolumn{4}{|c|}{$\overline{A F}$} & \multicolumn{4}{|c|}{$\overline{D F}$} \\
\hline & $\overline{F_{2: 9}}$ & $\mathrm{~F}_{2: 10}$ & $\mathrm{~F}_{2: 11}$ & Conjunta & $\mathrm{F}_{2: 9}$ & $F_{2: 10}$ & $\mathrm{~F}_{2: 11}$ & Conjunta \\
\hline $1 \times 2$ & $54,55 \mathrm{C}^{1}$ & $63,60 \mathrm{~B}$ & $44,53 \mathrm{C}$ & $54,23 \mathrm{~B}$ & $57,48 D$ & $49,43 \mathrm{~B}$ & $49,68 \mathrm{~F}$ & $52,20 \mathrm{~B}$ \\
\hline $1 \times 3$ & $58,62 \mathrm{C}$ & $68,89 \mathrm{~A}$ & $47,10 \mathrm{C}$ & $58,20 \mathrm{~B}$ & $58,88 \mathrm{D}$ & $51,11 \mathrm{~B}$ & $51,93 \mathrm{D}$ & $53,98 \mathrm{~B}$ \\
\hline $1 \times 4$ & $48,98 \mathrm{C}$ & $57,83 \mathrm{~B}$ & $45,13 \mathrm{C}$ & $50,65 \mathrm{~B}$ & $58,06 \mathrm{D}$ & $50,85 \mathrm{~B}$ & $50,54 E$ & $53,15 \mathrm{~B}$ \\
\hline $1 \times 6$ & $51,44 \mathrm{C}$ & $54,62 \mathrm{~B}$ & $41,46 \mathrm{D}$ & $49,17 \mathrm{~B}$ & $58,50 \mathrm{D}$ & $51,56 \mathrm{~B}$ & $52,50 \mathrm{C}$ & $54,19 \mathrm{~B}$ \\
\hline $1 \times 7$ & $54,36 \mathrm{C}$ & $58,49 \mathrm{~B}$ & $45,17 \mathrm{C}$ & $52,68 \mathrm{~B}$ & $59,61 \mathrm{D}$ & $51,68 \mathrm{~B}$ & $51,77 \mathrm{D}$ & $54,35 \mathrm{~B}$ \\
\hline $1 \times 8$ & 68,02 B & $73,14 \mathrm{~A}$ & $49,93 \mathrm{~B}$ & $63,70 \mathrm{~A}$ & $64,13 \mathrm{~B}$ & $54,23 \mathrm{~A}$ & $53,70 \mathrm{~B}$ & $57,35 \mathrm{~A}$ \\
\hline $2 \times 3$ & $59,43 \mathrm{C}$ & $65,42 \mathrm{~A}$ & $45,57 \mathrm{C}$ & $56,81 \mathrm{~B}$ & $58,28 \mathrm{D}$ & $52,13 \mathrm{~B}$ & $51,10 \mathrm{D}$ & $53,84 \mathrm{~B}$ \\
\hline $2 \times 4$ & $60,79 \mathrm{C}$ & $57,19 \mathrm{~B}$ & $48,84 \mathrm{~B}$ & $55,61 \mathrm{~B}$ & 57,76 D & $51,37 \mathrm{~B}$ & $50,25 \mathrm{E}$ & $53,13 \mathrm{~B}$ \\
\hline $2 \times 5$ & $58,02 \mathrm{C}$ & $61,33 \mathrm{~B}$ & $45,73 \mathrm{C}$ & $55,02 \mathrm{~B}$ & $57,55 \mathrm{D}$ & $50,47 \mathrm{~B}$ & $48,55 \mathrm{~F}$ & $52,19 \mathrm{~B}$ \\
\hline $2 \times 6$ & $62,20 \mathrm{~B}$ & $59,64 \mathrm{~B}$ & $41,73 \mathrm{D}$ & $54,53 \mathrm{~B}$ & $57,36 \mathrm{D}$ & $50,48 \mathrm{~B}$ & $48,85 \mathrm{~F}$ & $52,23 \mathrm{~B}$ \\
\hline $2 \times 8$ & $71,48 \mathrm{~A}$ & $81,27 \mathrm{~A}$ & $53,77 \mathrm{~A}$ & $68,84 \mathrm{~A}$ & $63,56 \mathrm{~B}$ & $56,17 \mathrm{~A}$ & $55,30 \mathrm{~A}$ & $58,34 \mathrm{~A}$ \\
\hline $3 \times 5$ & $59,99 \mathrm{C}$ & $56,29 \mathrm{~B}$ & $47,52 \mathrm{C}$ & $54,60 \mathrm{~B}$ & $56,68 \mathrm{D}$ & $47,39 \mathrm{~B}$ & $48,05 \mathrm{~F}$ & $50,71 B$ \\
\hline $3 \times 6$ & $57,52 \mathrm{C}$ & $59,41 \mathrm{~B}$ & $43,46 \mathrm{D}$ & $53,46 \mathrm{~B}$ & $58,89 \mathrm{D}$ & $47,93 \mathrm{~B}$ & $51,32 \mathrm{D}$ & $52,71 \mathrm{~B}$ \\
\hline $3 \times 7$ & $56,69 \mathrm{C}$ & $53,98 \mathrm{~B}$ & $45,79 \mathrm{C}$ & $52,15 \mathrm{~B}$ & $58,66 \mathrm{D}$ & $49,29 \mathrm{~B}$ & $51,67 \mathrm{D}$ & $53,20 \mathrm{~B}$ \\
\hline $3 \times 8$ & $73,65 \mathrm{~A}$ & $72,49 \mathrm{~A}$ & $55,54 \mathrm{~A}$ & $67,23 \mathrm{~A}$ & $63,73 \mathrm{~B}$ & $54,88 \mathrm{~A}$ & $54,84 \mathrm{~A}$ & $57,82 \mathrm{~A}$ \\
\hline $4 \times 5$ & $58,45 \mathrm{C}$ & $62,24 \mathrm{~B}$ & $48,43 \mathrm{~B}$ & $56,38 \mathrm{~B}$ & $58,09 \mathrm{D}$ & $52,63 \mathrm{~B}$ & $50,17 E$ & $53,63 \mathrm{~B}$ \\
\hline $4 \times 6$ & $53,15 \mathrm{C}$ & $55,52 \mathrm{~B}$ & $39,94 \mathrm{D}$ & $49,54 \mathrm{~B}$ & 57,76 D & $50,27 \mathrm{~B}$ & $48,33 \mathrm{~F}$ & $52,12 \mathrm{~B}$ \\
\hline $4 \times 7$ & $54,83 \mathrm{C}$ & $61,30 \mathrm{~B}$ & $46,34 \mathrm{C}$ & $54,16 \mathrm{~B}$ & $59,49 \mathrm{D}$ & $52,11 \mathrm{~B}$ & $52,40 \mathrm{C}$ & $54,67 \mathrm{~B}$ \\
\hline $4 \times 8$ & $73,42 \mathrm{~A}$ & $73,13 \mathrm{~A}$ & $56,05 \mathrm{~A}$ & $67,53 \mathrm{~A}$ & $65,41 \mathrm{~A}$ & $57,29 \mathrm{~A}$ & $56,07 \mathrm{~A}$ & $59,59 \mathrm{~A}$ \\
\hline $5 \times 6$ & $57,75 \mathrm{C}$ & $56,98 \mathrm{~B}$ & $41,78 \mathrm{D}$ & $52,17 \mathrm{~B}$ & $56,53 \mathrm{D}$ & $49,47 \mathrm{~B}$ & $48,03 \mathrm{~F}$ & $51,34 \mathrm{~B}$ \\
\hline $5 \times 7$ & $50,45 \mathrm{C}$ & $47,28 \mathrm{~B}$ & $45,35 \mathrm{C}$ & $47,69 \mathrm{~B}$ & $57,86 \mathrm{D}$ & $49,27 \mathrm{~B}$ & $48,48 \mathrm{~F}$ & $51,87 \mathrm{~B}$ \\
\hline $5 \times 8$ & $65,81 \mathrm{~B}$ & $69,08 \mathrm{~A}$ & $51,13 \mathrm{~B}$ & $62,01 \mathrm{~A}$ & $63,26 \mathrm{~B}$ & $56,09 \mathrm{~A}$ & $54,70 \mathrm{~A}$ & $58,02 \mathrm{~A}$ \\
\hline $6 \times 7$ & $53,79 \mathrm{C}$ & $51,76 \mathrm{~B}$ & $40,87 \mathrm{D}$ & $48,81 \mathrm{~B}$ & $58,47 \mathrm{D}$ & $50,25 \mathrm{~B}$ & $50,62 \mathrm{E}$ & $53,11 \mathrm{~B}$ \\
\hline $6 \times 8$ & $65,90 \mathrm{~B}$ & $67,73 \mathrm{~A}$ & 48,42 B & $60,68 \mathrm{~A}$ & $61,88 \mathrm{C}$ & $55,61 \mathrm{~A}$ & $53,82 \mathrm{~B}$ & $57,10 \mathrm{~A}$ \\
\hline $7 \times 8$ & $63,38 \mathrm{~B}$ & $68,79 \mathrm{~A}$ & $51,58 \mathrm{~B}$ & $61,25 \mathrm{~A}$ & $64,02 \mathrm{~B}$ & $59,63 \mathrm{~A}$ & $55,32 \mathrm{~A}$ & $59,66 \mathrm{~A}$ \\
\hline
\end{tabular}

1. Médias seguidas de letras diferentes pertencem a grupos distintos segundo a análise de agrupamento de Scott \& Knott 
4.6 Análise dialélica considerando as 25 populações

Conforme já destacado no capitulo anterior, as análises dialélicas para os caracteres produção de grãos e altura das plantas já haviam sido realizadas por Pulcinelli (1997). O autor estimou as médias das populações perdidas (1×5, 2x7 e 3×4) para realizar as análises conjuntas, enquanto neste trabalho as análises conjuntas foram realizadas sem a participação destas populações. Portanto, as maiores diferenças com relação ao dialelo para os caracteres altura das plantas na maturação e produção de grãos encontradas entre o presente trabalho e o realizado por Pulcinelli (1997) dizem respeito à análise conjunta.

As análises de variância do dialelo mostraram que as populações apresentaram diferentes significativas para a capacidade geral de combinação. A única análise em que não foi detectada diferença entre esses efeitos foi a realizada na geração $F_{2: 9}$ para acamamento (Tabela 29).

Os efeitos da capacidade especifica de combinação das populações foram estatisticamente diferentes em todas as análises realizadas para os caracteres altura das plantas na maturação e produção de grãos (Tabela 29). Para o caráter dias para o florescimento, esses efeitos foram significativos nas gerações $F_{2: 9}$ e $F_{2: 11}$. É provável que a ausência de significância para a capacidade especifica na geração $F_{2: 10}$ e na análise conjunta para o número de dias para o florescimento se deva ao maior valor do quadrado médio do resíduo verificado nestas análises, portanto, os efeitos devido à epistase devem possuir pequena magnitude e só foram detectáveis em experimentos com alto grau de precisão. Nos demais caracteres, os efeitos da capacidade especifica não foram superiores ao residuo experimental.

Quando o estudo dos componentes de média é realizada em gerações com coeficiente de endogamia próximo a 1 , os efeitos genéticos presentes são exclusivamente aditivos e epistáticos do tipo aditivo $x$ aditivo ou de ordens mais elevadas (Kearsey \& Pooni, 1996). A análise dialélica separa estes efeitos genéticos de tal maneira que os aditivos estão contidos na capacidade geral de combinação e a os efeitos epistáticos na capacidade especifica (Stuthman \& Stucker, 1975; Choo et al., 1986). 
Tabela 29. Resumo das análises de variância das tabelas dialélicas para os caracteres altura das plantas na maturação (AM), produção de grãos (PG), dias para a maturação (DM), altura das plantas no florescimento (AF), dias para o florescimento (DF) e acamamento (AC).

\begin{tabular}{|c|c|c|c|c|c|c|c|c|c|c|c|}
\hline \multirow[b]{2}{*}{ Caráter } & & \multicolumn{2}{|r|}{$F_{2: 8}$} & \multicolumn{2}{|r|}{$\mathrm{F}_{2: 9}$} & \multicolumn{2}{|r|}{$F_{2: 10}$} & \multicolumn{2}{|r|}{$F_{2: 11}$} & \multicolumn{2}{|c|}{ Conjunta } \\
\hline & & GL & QM & $G L$ & $\overline{Q M}$ & $G L$ & QM & $G L$ & QM & $G L$ & QM \\
\hline \multirow{5}{*}{ AM } & CGC & 7 & $265,47^{\star \star}$ & 7 & $629,99^{\star \star}$ & 7 & $219,05^{\star \star}$ & 7 & $285,64^{\star \star}$ & 7 & $325,15^{\star \star}$ \\
\hline & CEC & 17 & $11,16^{\star \star}$ & 17 & $21,79^{\star \star}$ & 17 & $9,94^{\star \star}$ & 17 & $13,15^{\star \star}$ & 17 & $10,08^{\star \star}$ \\
\hline & CGCxanos & - & - & - & - & - & - & - & - & 21 & $33,19^{\star \star}$ \\
\hline & CECxanos & - & - & - & - & - & - & - & - & 51 & 5,24 \\
\hline & Residuo & 36 & 2,11 & 16 & 5,75 & 36 & 5,70 & 36 & 3,42 & 124 & 4,09 \\
\hline \multirow{5}{*}{ PG } & CGC & 7 & $7412,27^{\star \star \star}$ & 7 & $4584,05^{\star \star}$ & 7 & $4066,68^{\star \star}$ & 7 & $3696,23^{\star \star}$ & 7 & $4264,32^{\star \star}$ \\
\hline & CEC & 17 & $736,68^{\star *}$ & 17 & $440,82^{\star \star}$ & 17 & $429,43^{\star \star}$ & 17 & $118,19^{\star \star}$ & 17 & $297,54^{\star \star}$ \\
\hline & CGCxanos & - & - & - & - & - & - & - & - & 21 & $900,65^{\star \star}$ \\
\hline & CECxanos & - & - & - & - & - & - & - & - & 51 & $178,32^{\star}$ \\
\hline & Residuo & 36 & 180,62 & 16 & 111,92 & 36 & 103,54 & 36 & 32,10 & 124 & 110,67 \\
\hline \multirow{5}{*}{ DM } & CGC & & & 7 & $3,15^{\star \star}$ & 7 & $2,77^{\star \star}$ & & & 7 & $2,19^{\star \star}$ \\
\hline & CEC & & & 17 & 0,69 & 17 & 0,44 & & & 17 & 0,45 \\
\hline & CGCxanos & & & & & & & & & 7 & $1,54^{\star *}$ \\
\hline & CECxanos & & & & & & & & & 17 & 0,23 \\
\hline & Resíduo & & & 16 & 0,72 & 36 & 0,23 & & & 52 & 0,37 \\
\hline \multirow{5}{*}{$A F$} & CGC & & & 7 & $141,70^{\star \star}$ & 7 & $181,70^{\star \star}$ & 7 & $61,16^{\star \star}$ & 7 & $113,46^{\star \star}$ \\
\hline & CEC & & & 17 & 8,49 & 17 & 14,83 & 17 & 1,95 & 17 & 4,39 \\
\hline & CGCxanos & & & - & - & - & - & - & - & 14 & $22,09^{\star}$ \\
\hline & CECxanos & & & - & - & - & - & - & - & 34 & 6,06 \\
\hline & Resíduo & & & 16 & 5,93 & 36 & 18,21 & 36 & 1,61 & 88 & 9,92 \\
\hline \multirow{5}{*}{ DF } & CGC & & & 7 & $24,14^{\star \star}$ & 7 & $27,37^{\star \star}$ & 7 & $18,33^{\star \star}$ & 7 & $22,37^{\star \star}$ \\
\hline & CEC & & & 17 & $0,49^{\star}$ & 17 & 2,03 & 17 & $1,33^{\star \star}$ & 17 & 0,80 \\
\hline & CGCxanos & & & - & - & - & - & - & - & 14 & 1,36 \\
\hline & CECxanos & & & - & - & - & - & - & - & 34 & 0,72 \\
\hline & Resíduo & & & 16 & 0,18 & 36 & 1,93 & 36 & 0,15 & 88 & 0,98 \\
\hline \multirow{5}{*}{$A C^{1}$} & CGC & 7 & $96,94^{\star}$ & 7 & 41,41 & & & & & 7 & $58,51^{\star \star}$ \\
\hline & CEC & 17 & 4,41 & 17 & 21,46 & & & & & 17 & 8,83 \\
\hline & CGCxanos & & & & & & & & & 7 & $79,84^{\star \star}$ \\
\hline & CECxanos & & & & & & & & & 17 & 17,05 \\
\hline & Resíduo & 36 & 3,60 & 16 & 30,16 & & & & & 52 & 10,40 \\
\hline
\end{tabular}


Portanto, para a produção de grãos e a altura das plantas na maturação, as diferenças entre populações quanto à altura na maturação são ocasionadas pela ação conjunta de efeitos gênicos aditivos e epistáticos (tipo aditivo $x$ aditivo, etc). Para $o$ número de dias para o florescimento a média das populações é determinada por efeitos aditivos e, em duas gerações, também por efeitos epistáticos. Para a altura das plantas no florescimento, dias para a maturação e acamamento, as populações diferiram entre si, basicamente, devido aos efeitos gênicos aditivos que atuam nestes caracteres.

Os efeitos aditivos da capacidade geral de combinação são transmitidos para as progênies e, caso não haja interação deste componente com o ambiente em gerações com endogamia baixa, eles podem ser preditos antes da fixação dos genótipos (Ramalho et al., 1988). Contudo, quando a interação é significativa, principalmente se complexa, a capacidade geral estimada em gerações segregantes e em poucos ambientes não deve ser capaz de realizar uma seleção efetiva.

Já os efeitos epistáticos são formados pela interação entre alelos de efeito aditivo presentes em locos diferentes (Kearsey \& Pooni, 1996). Portanto, este componente só será definido quando não houver mais recombinação e a população deixar de segregar. Se os efeitos epistáticos forem grandes, a capacidade geral de combinação pode não ser capaz de classificar adequadamente os genitores quanto ao seu potencial para a formação de populações endogâmicas (Stuthman \& Stucker, 1975; Choo et al., 1986).

Os valores dos quadrados médios associados à capacidade geral de combinação foram usualmente dez vezes maiores do que os da capacidade específica. Portanto, todas as análises realizadas neste estudo a importância dos efeitos epistáticos foram substancialmente menores que os efeitos aditivos (Cruz \& Regazzi,1997). Isto indica que a capacidade geral de combinação estimada em $F_{2}$ seria capaz de classificar com bom nível de acurácia as populações, conforme já havia sido verificado por Pulcinelli (1997) para a produção de grãos e a altura das plantas na maturação.

Também Thorne \& Fehr (1970) verificaram a existência de epistasia em populações endogâmicas de soja, mas seus efeitos foram menores do que os aditivos. As análises conjuntas permitiram verificar que os caracteres produção de grãos, altura das plantas na maturação, dias para a maturação, altura das plantas no 
florescimento e acamamento apresentaram interações significativas entre os efeitos da capacidade geral de combinação e anos. Portanto, os efeitos da capacidade geral de combinação destes caracteres foram melhor estimados na análise conjunta do que nas gerações individuais. Apenas a produção de grãos apresentou interação significativa entre a capacidade específica de combinação e os anos, logo os efeitos epistáticos que atuaram neste caráter foram estimados de maneira mais precisa na análise conjunta.

Segundo os efeitos da capacidade geral estimados $\left(g_{i}\right)$ para a altura das plantas na maturação, as linhagens 2, 7 e 8 contribuem para o aumento da altura das populações (Tabela 30) e as demais linhagens contribuem para a redução da altura das populações. As linhagens 8 e 6 foram as que mais contribuíram para o aumento e redução da altura das plantas na maturação, respectivamente. Estes resultados foram obtidos em todas as avaliações realizadas e na análise conjunta, mostrando que, embora a interação da capacidade geral e anos tenha sido significativa, o sentido da contribuição das linhagens não foi alterado pelas condições ambientais existentes nos anos em que as avaliações foram realizadas.

Os efeitos da capacidade especifica da altura das plantas na maturação foram menores do que os da capacidade geral. Embora estes efeitos tenham sido razoavelmente constantes ao longo dos anos, em muitas populações existiram alterações quanto ao sentido em que atuaram, mostrando que os efeitos epistáticos presentes em algumas populações podem atuar no sentido de aumentar ou diminuir a altura das plantas, de acordo com as condições ambientais.

Os valores dos parâmetros estimados para o número de dias para a maturação foram baixos, indicando que as populações foram bastante homogêneas com relação à este caráter (Tabela 30). Apenas a capacidade geral do genitor 6 e algumas capacidades especificas apresentaram efeitos superiores a 1. Ou seja, os maiores efeitos observados foram capazes de aumentar ou reduzir em apenas um dia o ciclo das populações. 
Tabela 30. Estimativas dos parâmetros dos caracteres altura das plantas na maturação $(A M)$ e dias para a maturação (DM), obtidas pela análise dialélica da geração $F_{2: n}$, segundo o modelo 1 de Griffing método 4

\begin{tabular}{|c|c|c|c|c|c|c|c|c|}
\hline \multirow[b]{2}{*}{ Parâmetro } & \multicolumn{5}{|c|}{$\overline{A M}$} & \multicolumn{3}{|c|}{$\overline{D M}$} \\
\hline & $F_{2: 8}$ & $F_{2: 9}$ & $F_{2: 10}$ & $F_{2: 11}$ & Conjunta & $F_{2: 9}$ & $F_{2 \cdot 11}$ & Conjunta \\
\hline$\mu$ & 73,44 & 84,10 & 77,05 & 66,31 & 75,22 & 131,54 & 127,28 & 129,41 \\
\hline$g_{1}$ & $-7,23$ & $-10,07$ & $-4,06$ & $-5,86$ & $-6,80$ & $-0,17$ & 0,65 & 0,24 \\
\hline$g_{2}$ & 10,18 & 12,08 & 8,53 & 10,33 & 10,28 & 0,69 & 0,27 & 0,48 \\
\hline$g_{3}$ & $-4,64$ & $-5,10$ & $-3,53$ & $-3,14$ & $-4,10$ & 0,63 & 0,36 & 0,49 \\
\hline$g_{4}$ & $-2,98$ & $-7,71$ & $-3,51$ & $-2,51$ & $-4,18$ & 0,89 & $-0,15$ & 0,37 \\
\hline$g_{5}$ & $-5,22$ & $-8,98$ & $-6,48$ & $-4,23$ & $-6,23$ & 0,14 & $-0,60$ & $-0,23$ \\
\hline$g_{6}$ & $-5,31$ & $-7,47$ & $-5,93$ & $-9,65$ & $-7,09$ & $-1,18$ & $-1,17$ & $-1,17$ \\
\hline$g_{7}$ & 4,23 & 8,45 & 5,18 & 4,98 & 5,71 & $-0,99$ & $-0,26$ & $-0,62$ \\
\hline$g_{8}$ & 10,97 & 18,80 & 9,79 & 10,08 & 12,41 & $-0,01$ & 0,90 & 0,44 \\
\hline$s_{12}$ & 0,74 & 0,11 & 4,97 & $-0,51$ & 1,33 & $-0,29$ & 0,35 & 0,03 \\
\hline$S_{13}$ & 1,57 & 6,24 & 0,87 & 5,13 & 3,45 & $-0,33$ & 0,35 & 0,01 \\
\hline $\mathrm{S}_{14}$ & $-3,75$ & $-7,71$ & $-4,23$ & $-2,62$ & $-4,58$ & $-1,38$ & $-0,75$ & $-1,06$ \\
\hline$S_{16}$ & $-0,65$ & 0,45 & $-1,90$ & 0,03 & $-0,52$ & 0,38 & 0,48 & 0,43 \\
\hline$s_{17}$ & 3,58 & 4,03 & 1,74 & 2,65 & 3,00 & $-0,05$ & $-0,38$ & $-0,22$ \\
\hline $\mathrm{s}_{18}$ & $-1,49$ & $-3,13$ & $-1,45$ & $-4,68$ & $-2,69$ & 1,67 & $-0,05$ & 0,81 \\
\hline $\mathrm{s}_{23}$ & $-2,45$ & $-7,06$ & $-3,89$ & $-7,01$ & $-5,10$ & $-0,03$ & $-0,64$ & $-0,34$ \\
\hline $\mathrm{S}_{24}$ & 0,21 & 5,24 & $-0,12$ & 4,13 & 2,36 & 0,23 & 0,09 & 0,16 \\
\hline $\mathrm{S}_{25}$ & 1,04 & $-1,58$ & $-3,95$ & $-1,38$ & $-1,47$ & 0,46 & 0,54 & 0,50 \\
\hline$s_{26}$ & $-2,83$ & 3,07 & $-0,45$ & $-0,72$ & $-0,23$ & $-0,59$ & $-1,08$ & $-0,83$ \\
\hline $\mathrm{S}_{28}$ & 3,29 & 0,23 & 3,44 & 5,49 & 3,11 & 0,23 & 0,74 & 0,48 \\
\hline $\mathrm{S}_{35}$ & 0,49 & 1,61 & 0,37 & 1,66 & 1,03 & 0,11 & 0,23 & 0,17 \\
\hline $\mathrm{s}_{36}$ & 4,39 & 0,04 & 3,15 & 2,72 & 2,57 & 0,02 & $-0,62$ & $-0,30$ \\
\hline$s_{37}$ & $-3,13$ & $-2,18$ & 0,29 & $-3,92$ & $-2,24$ & 0,65 & 0,95 & 0,80 \\
\hline $\mathrm{S}_{38}$ & $-0,87$ & 1,34 & $-0,79$ & 1,43 & 0,28 & $-0,43$ & $-0,27$ & $-0,35$ \\
\hline$S_{45}$ & 1,03 & 2,75 & 3,10 & $-1,09$ & 1,45 & 1,55 & 0,44 & 1,00 \\
\hline $\mathrm{S}_{46}$ & $-4,94$ & $-4,13$ & $-3,44$ & $-1,78$ & $-3,58$ & 0,23 & 0,51 & 0,37 \\
\hline $\mathrm{s}_{47}$ & 5,75 & 6,20 & 4,03 & 2,51 & 4,62 & 0,04 & $-0,22$ & $-0,09$ \\
\hline $\mathrm{S}_{48}$ & 1,71 & $-2,34$ & 0,67 & $-1,16$ & $-0,28$ & $-0,67$ & $-0,07$ & $-0,37$ \\
\hline$S_{56}$ & 3,54 & 3,51 & 2,93 & 3,22 & 3,30 & $-0,47$ & $-0,02$ & $-0,25$ \\
\hline $\mathrm{S}_{57}$ & $-4,75$ & $-6,34$ & $-1,50$ & $-1,02$ & $-3,40$ & $-1,22$ & $-1,07$ & $-1,14$ \\
\hline$S_{58}$ & $-1,34$ & 0,05 & $-0,95$ & $-1,39$ & $-0,91$ & $-0,43$ & $-0,13$ & $-0,28$ \\
\hline$S_{67}$ & 0,18 & $-4,26$ & $-1,97$ & $-2,00$ & $-2,01$ & 0,68 & 0,83 & 0,76 \\
\hline$s_{68}$ & 0,31 & 1,32 & 1,68 & $-1,47$ & 0,46 & $-0,26$ & $-0,10$ & $-0,18$ \\
\hline$S_{78}$ & $-1,62$ & 2,54 & $-2,59$ & 1,78 & 0,03 & $-0,11$ & $-0,12$ & $-0,11$ \\
\hline
\end{tabular}


Para o caráter produção de grãos, os genitores não adaptados tenderam a apresentar os menores valores de capacidade geral de combinação e os adaptados os valores mais altos (Tabela 31). A magnitude da capacidade especifica de combinação de algumas populações foi bastante alta, indicando que estes efeitos devem ser considerados para explicar o comportamento das populações. Os efeitos da capacidade geral e da capacidade específica sofreram alterações de sinal de acordo com o ano analisado. Isto mostra que além de serem mais precisas, as estimativas obtidas a partir da análise conjunta devem mostrar o sentido mais provável de atuação dos efeitos epistáticos e aditivos na produção de grãos em um ano qualquer

Os genitores 7 e 8 foram os que apresentaram maiores capacidades gerais de combinação para o caráter acamamento (Tabela 31). Nos demais genitores, a capacidade geral foi negativa ou muito próxima a zero. Embora não significativos, os efeitos da capacidade específica de combinação verificados em algumas populações foram altos, como no caso da população 1x8. O sinal das estimativas dos efeitos da capacidade geral de combinação foram constante ao longo das avaliações, mostrando os genitores sempre contribuíram para a formação da média das populações no mesmo sentido.

Para o caráter altura das plantas no florescimento, o genitor 8 apresentou capacidade geral de combinação muito superior aos demais (Tabela 32), o que indica que sua utilização resultou em maior altura ao final do periodo vegetativo. As capacidades de combinação dos genitores 1, 2 e 4 apresentaram valores positivos ou negativos, de acordo com o ano em que a avaliação foi realizada. Portanto, as estimativas dos efeitos da capacidade geral obtidas pela análise conjunta foram mais acuradas e revelam qual o sentido mais provável de atuação dos efeitos aditivos presentes nestes genitores na altura das plantas medida no florescimento.

O genitor 8 também apresentou uma capacidade geral de combinação muito alta no caráter dias para o florescimento (Tabela 32). Para contrabalançar esta grande capacidade geral, todos os demais apresentaram valores negativos ou próximos a zero. 
Tabela 31. Estimativas dos parâmetros dos caracteres produção de grãos (PG) e acamamento $(A C)$ obtidas pela análise dialélica da geração $F_{2: n}$, segundo o modelo I de Griffing método 4.

\begin{tabular}{|c|c|c|c|c|c|c|c|c|}
\hline \multirow[b]{2}{*}{ Parâmetro } & \multicolumn{5}{|c|}{$P G$} & \multicolumn{3}{|c|}{$\overline{A C}$} \\
\hline & $F_{2: 8}$ & $\mathrm{~F}_{2: 9}$ & $\mathrm{~F}_{2: 10}$ & $F_{2: 11}$ & Conjunta & $\mathrm{F}_{2: 8}$ & $\mathrm{~F}_{2: 9}$ & Conjunta \\
\hline$\mu$ & 261,18 & 212,43 & 156,08 & 143,61 & 193,33 & 1,8182 & 1,8017 & 1,8099 \\
\hline$g_{1}$ & $-15,67$ & $-1,69$ & 12,20 & 4,58 & $-0,15$ & $-0,0929$ & $-0,0674$ & $-0,0802$ \\
\hline$g_{2}$ & $-7,01$ & 15,21 & $-3,41$ & 5,04 & 2,46 & 0,0078 & $-0,0705$ & $-0,0314$ \\
\hline$g_{3}$ & 30,76 & 36,57 & 44,18 & 30,65 & 35,54 & $-0,1509$ & $-0,1219$ & $-0,1364$ \\
\hline$g_{4}$ & 51,72 & 27,85 & 32,18 & 26,62 & 34,59 & $-0,1195$ & $-0,0407$ & $-0,0801$ \\
\hline$g_{5}$ & 16,30 & 20,94 & $-2,71$ & 15,62 & 12,54 & $-0,0818$ & 0,0611 & $-0,0104$ \\
\hline$g_{6}$ & $-70,63$ & $-38,81$ & $-36,60$ & $-42,06$ & $-47,03$ & 0,0245 & 0,0585 & 0,0415 \\
\hline$g_{7}$ & $-22,21$ & $-37,58$ & $-38,64$ & $-37,40$ & $-33,96$ & 0,2050 & 0,0483 & 0,1266 \\
\hline$g_{8}$ & 16,74 & $-22,49$ & $-7,20$ & $-3,04$ & $-3,99$ & 0,2079 & 0,1325 & 0,1702 \\
\hline$s_{12}$ & 9,16 & 17,95 & 28,65 & $-2,35$ & 13,35 & $-0,0470$ & 0,0245 & $-0,0113$ \\
\hline$s_{13}$ & 2,72 & 15,91 & $-11,84$ & 3,82 & 2,65 & 0,0565 & 0,1366 & 0,0966 \\
\hline$S_{14}$ & 8,10 & 7,32 & 31,43 & 13,01 & 14,96 & 0,0206 & 0,1590 & 0,0898 \\
\hline$s_{16}$ & $-38,31$ & $-20,39$ & $-30,13$ & $-18,10$ & $-26,73$ & $-0,0168$ & 0,0403 & 0,0117 \\
\hline$s_{17}$ & 13,58 & $-13,86$ & $-16,91$ & 1,91 & $-3,82$ & 0,1228 & 0,0180 & 0,0704 \\
\hline $\mathrm{S}_{18}$ & 4,75 & $-6,92$ & $-1,20$ & 1,71 & $-0,42$ & $-0,1361$ & $-0,3784$ & $-0,2572$ \\
\hline $\mathrm{s}_{23}$ & 8,27 & $-6,79$ & 5,92 & $-4,79$ & 0,65 & 0,0344 & $-0,0608$ & $-0,0132$ \\
\hline $\mathrm{S}_{24}$ & $-9,62$ & $-0,40$ & $-24,56$ & 0,83 & $-8,44$ & 0,0209 & $-0,0241$ & $-0,0016$ \\
\hline $\mathrm{s}_{25}$ & 5,52 & $-1,26$ & $-12,16$ & $-1,40$ & $-2,33$ & $-0,0072$ & $-0,0103$ & $-0,0088$ \\
\hline $\mathrm{s}_{26}$ & $-17,75$ & 4,69 & $-0,10$ & $-1,17$ & $-3,58$ & 0,0357 & $-0,0077$ & 0,0140 \\
\hline $\mathrm{s}_{28}$ & 4,43 & $-14,19$ & 2,26 & 8,88 & 0,34 & $-0,0368$ & 0,0785 & 0,0209 \\
\hline $\mathrm{S}_{35}$ & $-20,02$ & 2,53 & $-19,55$ & 7,78 & $-7,32$ & $-0,0385$ & 0,0904 & 0,0260 \\
\hline $\mathrm{s}_{36}$ & 12,68 & $-15,45$ & 9,35 & $-4,99$ & 0,40 & $-0,0259$ & 0,0442 & 0,0092 \\
\hline$s_{37}$ & $-11,47$ & $-0,29$ & 2,41 & $-3,90$ & $-3,31$ & $-0,0121$ & $-0,0580$ & $-0,0351$ \\
\hline$s_{38}$ & 7,82 & 4,08 & 13,70 & 2,08 & 6,92 & $-0,0145$ & $-0,1524$ & $-0,0834$ \\
\hline $\mathrm{S}_{45}$ & 44,66 & 16,96 & 27,66 & 10,29 & 24,89 & $-0,0050$ & $-0,1781$ & $-0,0915$ \\
\hline$S_{46}$ & $-45,44$ & $-45,80$ & $-25,71$ & $-11,28$ & $-32,06$ & $-0,0318$ & $-0,0867$ & $-0,0592$ \\
\hline $\mathrm{S}_{47}$ & 11,91 & 7,84 & $-3,22$ & $-8,63$ & 1,97 & $-0,0377$ & $-0,0041$ & $-0,0209$ \\
\hline $\mathrm{S}_{48}$ & $-9,60$ & 14,08 & $-5,61$ & $-4,22$ & $-1,34$ & 0,0330 & 0,1340 & 0,0835 \\
\hline $\mathrm{S}_{56}$ & 11,32 & 13,56 & 20,55 & $-0,52$ & 11,23 & 0,0076 & $-0,1247$ & $-0,0586$ \\
\hline$S_{57}$ & $-30,93$ & $-22,20$ & $-7,79$ & $-3,28$ & $-16,05$ & 0,0160 & 0,0180 & 0,0170 \\
\hline $\mathrm{S}_{58}$ & $-10,56$ & $-9,59$ & $-8,71$ & $-12,86$ & $-10,43$ & 0,0271 & 0,2047 & 0,1159 \\
\hline$S_{67}$ & 45,62 & 39,68 & 25,99 & 22,77 & 33,52 & $-0,0925$ & 0,0236 & $-0,0344$ \\
\hline $\mathrm{S}_{68}$ & 31,89 & 23,71 & 0,05 & 13,28 & 17,23 & 0,1238 & 0,1110 & 0,1174 \\
\hline $\mathrm{S}_{78}$ & $-28,71$ & $-11,17$ & $-0,48$ & $-8,87$ & $-12,31$ & 0,0034 & 0,0026 & 0,0030 \\
\hline
\end{tabular}


Tabela 32. Estimativas dos parâmetros dos caracteres altura das plantas no florescimento (AF) e dias para o florescimento (DF) obtidas pela análise dialélica da geração $F_{2: n}$, segundo o modelo I de Griffing método 4.

\begin{tabular}{|c|c|c|c|c|c|c|c|c|}
\hline \multirow[b]{2}{*}{ Parâmetro } & \multicolumn{4}{|c|}{$\overline{A F}$} & \multicolumn{4}{|c|}{$\overline{D F}$} \\
\hline & $F_{2: 9}$ & $F_{2: 10}$ & $F_{2: 11}$ & Conjunta & $F_{2: 9}$ & $F_{2: 10}$ & $F_{2: 11}$ & Conjunta \\
\hline$\mu$ & 59,36 & 62,01 & 46,79 & 56,05 & $59,5 \overline{3}$ & 51,91 & 51,40 & 54,28 \\
\hline$g_{1}$ & $-4,44$ & 0,15 & $-1,57$ & $-1,95$ & $-0,41$ & $-0,80$ & $-0,08$ & $-0,43$ \\
\hline$g_{2}$ & 1,21 & 2,15 & $-0,35$ & 1,00 & $-1,04$ & $-0,26$ & $-0,90$ & $-0,73$ \\
\hline$g_{3}$ & 1,76 & 0,72 & 1,06 & 1,18 & $-0,45$ & $-1,70$ & 0,08 & $-0,69$ \\
\hline $\mathrm{g}_{4}$ & $-0,95$ & $-0,82$ & 1,02 & $-0,25$ & $-0,21$ & 0,27 & $-0,12$ & $-0,02$ \\
\hline$g_{5}$ & $-2,02$ & $-3,74$ & $-0,47$ & $-2,08$ & $-1,52$ & $-1,39$ & $-2,10$ & $-1,67$ \\
\hline$g_{6}$ & $-2,29$ & $-4,73$ & $-4,97$ & $-4,00$ & $-1,22$ & $-1,30$ & $-1,06$ & $-1,19$ \\
\hline$g_{7}$ & $-4,29$ & $-5,66$ & $-1,19$ & $-3,71$ & $-0,02$ & 0,10 & 0,19 & 0,09 \\
\hline$g_{8}$ & 11,03 & 11,93 & 6,48 & 9,81 & 4,88 & 5,09 & 3,99 & 4,65 \\
\hline$s_{12}$ & $-1,57$ & $-0,71$ & $-0,33$ & $-0,87$ & $-0,60$ & $-1,42$ & $-0,74$ & $-0,92$ \\
\hline$s_{13}$ & 1,94 & 6,01 & 0,83 & 2,93 & 0,21 & 1,69 & 0,53 & 0,81 \\
\hline$S_{14}$ & $-4,98$ & $-3,51$ & $-1,10$ & $-3,20$ & $-0,85$ & $-0,53$ & $-0,67$ & $-0,68$ \\
\hline$s_{16}$ & $-1,19$ & $-2,81$ & 1,22 & $-0,93$ & 0,60 & 1,75 & 2,24 & 1,53 \\
\hline$s_{17}$ & 3,73 & 1,99 & 1,15 & 2,29 & 0,51 & 0,47 & 0,25 & 0,41 \\
\hline$S_{18}$ & 2,07 & $-0,95$ & $-1,77$ & $-0,22$ & 0,13 & $-1,97$ & $-1,61$ & $-1,15$ \\
\hline $\mathrm{s}_{23}$ & $-2,90$ & 0,54 & $-1,92$ & $-1,43$ & 0,25 & 2,17 & 0,52 & 0,98 \\
\hline$s_{24}$ & 1,18 & $-6,14$ & 1,39 & $-1,19$ & $-0,52$ & $-0,55$ & $-0,14$ & $-0,40$ \\
\hline $\mathrm{s}_{25}$ & $-0,52$ & 0,91 & $-0,24$ & 0,05 & 0,59 & 0,21 & 0,15 & 0,32 \\
\hline $\mathrm{S}_{26}$ & 3,93 & 0,22 & 0,27 & 1.47 & 0,09 & 0,14 & $-0,60$ & $-0,12$ \\
\hline $\mathrm{S}_{28}$ & $-0,11$ & 5,18 & 0,85 & 1,97 & 0,19 & $-0,56$ & 0,81 & 0,14 \\
\hline $\mathrm{s}_{35}$ & 0,89 & $-2,70$ & 0,15 & $-0,55$ & $-0,87$ & $-1,44$ & $-1,33$ & $-1,21$ \\
\hline$s_{36}$ & $-1,31$ & 1,41 & 0,59 & 0,23 & 1,03 & $-0,99$ & 0,90 & 0,31 \\
\hline$s_{37}$ & $-0,14$ & $-3,09$ & $-0,86$ & $-1,36$ & $-0,40$ & $-1,03$ & 0,00 & $-0,47$ \\
\hline $\mathrm{S}_{38}$ & 1,51 & $-2,17$ & 1,21 & 0,19 & $-0,23$ & $-0,42$ & $-0,62$ & $-0,42$ \\
\hline $\mathrm{S}_{45}$ & 2,07 & 4,80 & 1,10 & 2,66 & 0,29 & 1,84 & 0,98 & 1,04 \\
\hline $\mathrm{S}_{46}$ & $-2,96$ & $-0,93$ & $-2,89$ & $-2,26$ & $-0,34$ & $-0,61$ & $-1,89$ & $-0,95$ \\
\hline$S_{47}$ & 0,71 & 5,78 & $-0,27$ & 2,07 & 0,20 & $-0,17$ & 0,93 & 0,32 \\
\hline $\mathrm{S}_{48}$ & 3,98 & 0,01 & 1,76 & 1,92 & 1,21 & 0,02 & 0,79 & 0,67 \\
\hline$S_{56}$ & 2,71 & 3,44 & 0,44 & 2,20 & $-0,26$ & 0,25 & $-0,21$ & $-0,07$ \\
\hline$S_{57}$ & $-2,60$ & $-5,33$ & 0,23 & $-2,57$ & $-0,12$ & $-1,35$ & $-1,01$ & $-0,83$ \\
\hline$S_{58}$ & $-2,55$ & $-1,12$ & $-1,67$ & $-1,78$ & 0,37 & 0,49 & 1,41 & 0,76 \\
\hline $\mathrm{S}_{67}$ & 1,01 & 0,15 & 0,25 & 0,47 & 0,18 & $-0,46$ & 0,09 & $-0,06$ \\
\hline$s_{68}$ & $-2,19$ & $-1,47$ & 0,12 & $-1,18$ & $-1,31$ & $-0,08$ & $-0,52$ & $-0,64$ \\
\hline $\mathrm{S}_{78}$ & $-2,71$ & 0,51 & $-0,50$ & $-0,90$ & $-0,37$ & 2,53 & $-0,26$ & 0,64 \\
\hline
\end{tabular}


4.7 Análise dialélica parcial considerando a existência de dois grupos de genitores.

A análise de variância do dialelo parcial mostrou que os efeitos da capacidade geral do grupo de genótipos não adaptados foram quase sempre significativos (Tabela 33). Apenas para o caráter acamamento na geração $F_{2: 9}$ e na análise conjunta estes efeitos não foram maiores que o residuo experimental.

Os efeitos da capacidade geral de combinação dos genitores adaptados foram significativos em todas as análises realizadas para os caracteres altura das plantas na maturação e produção de grãos. Para o número de dias para a maturação e para o número de dias para o florescimento estes efeitos não foram significativos apenas na geração $F_{2: 10}$ e $F_{2: 9}$, respectivamente. A ausência de diferenças significativas nestas gerações provavelmente foi devida à menor precisão dos experimentos realizados nestes anos. Para acamamento e altura das plantas no florescimento, os efeitos da capacidade geral de combinação dos genitores adaptados não foram significativos em nenhuma análise.

Os efeitos da capacidade especifica de combinação foram sempre significativos para caracteres produção de grãos e altura das plantas na maturação e na geração $F_{2: 11}$ para o número de dias para o florescimento. Nos demais caracteres, não se verificaram efeitos significativos da capacidade especifica.

Os valores dos quadrados médios da capacidade geral de combinação das linhagens não adaptadas foram quase sempre superiores aos associados à capacidade geral do grupo de linhagens adaptadas. Os quadrados médios associados à capacidade especifica de combinação foram os menores verificados.

Como os efeitos da capacidade geral fomecem informações a respeito dos genes aditivos e os quadrados médios associados podem ser utilizados para determinar a importância dos componentes de média (Cruz \& Regazzi, 1997), podemos concluir que os genes com efeitos aditivos presentes nos genitores não adaptados foram os principais responsáveis pelas diferenças entre as populações. Os efeitos aditivos das linhagens genitoras adaptadas também foram mais importantes do que os efeitos epistáticos (aditivo $x$ aditivo, aditivo $\times$ aditivo $\times$ aditivo, etc).

As análises conjuntas mostraram que os efeitos da capacidade geral de combinação dos genitores não adaptados apresentaram interação com os anos nos caracteres altura das plantas na maturação, produção de grãos, altura das plantas 
Tabela 33. Análises de variância dos dialelos parciais na geração $F_{2: n}$, nos quatro anos de avaliação e na análise conjunta.

\begin{tabular}{|c|c|c|c|c|c|c|c|c|c|c|c|}
\hline \multirow{2}{*}{\multicolumn{2}{|c|}{ Caráter }} & \multicolumn{2}{|r|}{$\overline{F_{2: 8}}$} & \multicolumn{2}{|r|}{$\overline{F_{2: 9}}$} & \multicolumn{2}{|r|}{$F_{2: 10}$} & \multicolumn{2}{|r|}{$\overline{F_{2 \cdot 11}}$} & \multicolumn{2}{|c|}{ Conjunta } \\
\hline & & $\overline{G L}$ & QM & $\overline{G L}$ & QM & GL & QM & $G L$ & QM & $\mathrm{GL}$ & $\overline{Q M}$ \\
\hline \multirow{7}{*}{$A M$} & $\mathrm{CGC}_{\text {adaptado }}$ & 4 & $104,14^{\star \star}$ & 4 & $207,28^{\star *}$ & 4 & $91,97^{\star \star}$ & 4 & $120,50^{\star \star}$ & 4 & $125,36^{\star \star}$ \\
\hline & $\mathrm{CGC}_{\text {não adaptado }}$ & 2 & $350,13^{\star \star}$ & 2 & $793,86^{\star \star}$ & 2 & $341,91^{\star \star}$ & 2 & $483,56^{\star \star}$ & 2 & $474,46^{\star \star}$ \\
\hline & CEC & 7 & $22,25^{\star \star}$ & 7 & $19,99^{\star \star}$ & 7 & 8,35 & 7 & $13,43^{\star *}$ & 7 & $12,69^{\star \star}$ \\
\hline & $\mathrm{CGC}_{\text {adap }} \times$ anos & & & & & & & & & 12 & 7,49 \\
\hline & $\mathrm{CGC}_{\text {nåo }} \mathrm{x}$ anos & & & & & & & & & 6 & $23,88^{\star \star}$ \\
\hline & CEC $X$ & & & & & & & & & 21 & 4,41 \\
\hline & Residuo & 36 & 2,11 & 16 & 5,75 & 36 & 5,70 & 36 & 3,42 & 124 & 4,09 \\
\hline \multirow{7}{*}{$P G$} & $\mathrm{CGC}_{\text {adaptado }}$ & 4 & $2007,47^{\star \star}$ & 4 & $936,20^{\star \star}$ & 4 & $1709,19^{\star \star}$ & 4 & $334,63^{\star \star}$ & 4 & $1019,79^{\star *}$ \\
\hline & $\mathrm{CGC}_{\text {năo adaptado }}$ & 2 & $13171,40^{\star \star}$ & 2 & $921,93^{\star *}$ & 2 & $2019,28^{\star \star}$ & 2 & $2772,91^{\star \star}$ & 2 & $3474,45^{\star \star}$ \\
\hline & CEC & 7 & $583,68^{\star \star}$ & 7 & $434,68^{\star \star}$ & 7 & 178,98 & 7 & 47,91 & 7 & 196,57 \\
\hline & $\mathrm{CGC}_{\text {adap }} \mathrm{X}$ anos & & & & & & & & & 12 & $302,77^{\star}$ \\
\hline & $\mathrm{CGC}_{\text {năo }} \times$ anos & & & & & & & & & 6 & $1662,57^{\star \star}$ \\
\hline & CEC $X$ anos & & & & & & & & & 21 & 152,99 \\
\hline & Resid & 36 & 180,62 & 16 & 111,92 & 36 & 103,54 & 36 & 32,10 & 124 & 110,67 \\
\hline \multirow{7}{*}{ DM } & $\mathrm{CGC}_{\text {adaptado }}$ & & & 4 & 0,87 & & & 4 & $1,21^{\star}$ & 4 & 0,94 \\
\hline & $\mathrm{CGC}_{\text {náo }}$ & & & 2 & $2,65^{\star}$ & & & 2 & $6,45^{\star \star}$ & 2 & $4,25^{\star \star}$ \\
\hline & CEC & & & 7 & 0,46 & & & 7 & 0,60 & 7 & 0,42 \\
\hline & $\mathrm{CGC}_{\text {adap }} \mathrm{x}$ anos & & & & & & & & & 4 & 0,19 \\
\hline & $\mathrm{CGC}_{\text {nåo }} \times$ anos & & & & & & & & & 2 & 0,60 \\
\hline & CEC $x$ anos & & & & & & & & & 7 & 0,23 \\
\hline & Residuo & & & 16 & 0,72 & & & 36 & 0,23 & 52 & 0,37 \\
\hline \multirow{7}{*}{ AF } & $\mathrm{CGC}_{\text {adaptado }}$ & & & 4 & 18,52 & 4 & 28,31 & 4 & 3,58 & 4 & 11,58 \\
\hline & $\mathrm{CGC}_{\text {nâo }}$ & & & 2 & $343,86^{\star \star}$ & 2 & $452,75^{\star \star}$ & 2 & $172,51^{\star \star}$ & 2 & $303,18^{\star *}$ \\
\hline & CEC & & & 7 & 9,43 & 7 & 14,29 & 7 & 3,09 & 7 & 4,62 \\
\hline & $\mathrm{CGC}_{\text {adap }} \mathrm{x}$ anos & & & & & & & & & 8 & 7,82 \\
\hline & $\mathrm{CGC}_{\text {năo }} \mathrm{x}$ & & & & & & & & & 4 & $29,78^{\star \star}$ \\
\hline & CEC $\times$ anos & & & & & & & & & 14 & 6,48 \\
\hline & Residuo & & & 16 & 5,93 & 36 & 18,21 & 36 & 1,61 & 88 & 9,92 \\
\hline \multirow{7}{*}{ DF } & $\mathrm{CGC}_{\text {adaptado }}$ & & & 4 & $1,43^{\star \star}$ & 4 & 2,83 & 4 & $2,62^{\star \star}$ & 4 & 1,39 \\
\hline & $\mathrm{CGC}_{\text {não }}$ & & & 2 & $54,25^{\star \star}$ & 2 & $47,96^{\star \star}$ & 2 & $35,17^{\star \star}$ & 2 & $45,36^{\star \star}$ \\
\hline & CEC & & & 7 & 0,37 & 7 & 1,24 & 7 & $2,52^{\star \star}$ & 7 & 0,94 \\
\hline & $\mathrm{CGC}_{\text {adap }} \mathrm{x}$ anos & & & & & & & & & 8 & 1,36 \\
\hline & $\mathrm{CGC}_{\text {กə̊o }} \times$ anos & & & & & & & & & 4 & 0,64 \\
\hline & CEC $x$ anos & & & & & & & & & 14 & 0,65 \\
\hline & Resíduo & & & 16 & 0,18 & 36 & 1,93 & 36 & 0,15 & 88 & 0,98 \\
\hline \multirow{7}{*}{$A C^{1}$} & $\mathrm{CGC}_{\text {adaptado }}$ & 4 & $11,96^{\star \star}$ & 4 & 39,43 & & & & & 4 & 18,56 \\
\hline & $\mathrm{CGC}_{\text {não adaptado }}$ & 2 & $56,50^{\star \star}$ & 2 & 7,90 & & & & & 2 & 22,92 \\
\hline & CEC & 7 & 4,85 & 7 & 30,06 & & & & & 7 & 12,52 \\
\hline & $\mathrm{CGC}_{\text {adap }} \mathrm{x}$ anos & & & & & & & & & 4 & $32,83^{\star}$ \\
\hline & $\mathrm{CGC}_{\text {nāo }} \mathrm{x}$ anos & & & & & & & & & 2 & $41,48^{\star}$ \\
\hline & CEC $x$ anos & & & & & & & & & 7 & $22,39^{\star}$ \\
\hline & Resíduo & 36 & $3,60^{1}$ & 16 & 30,15 & & & & & 52 & 10,40 \\
\hline
\end{tabular}

AC - Acamamento; AF - Altura das plantas no florescimento; AM - altura das plantas na maturação; DF dias para o florescimento; DM - dias para a maturação; $P G$ - produção de grãos

1. Quadrados médios multiplicados por $10^{3}$ 
no florescimento e acamamento. A interação entre a capacidade geral do grupo dos genitores adaptados com os anos foi significativa nos caracteres produção de grãos e altura das plantas na maturação. A interação significativa indica que as estimativas obtidas na análise conjunta foram mais precisas.

Observando a Tabela 34, verifica-se que entre os genitores adaptados, apenas - genitor 2 possui capacidade geral positiva para o caráter altura das plantas na maturação. Entre o grupo não adaptado, o genitor 6 possui capacidade geral negativa e os genitores 7 e 8 valores positivos. Embora as interações entre as capacidades gerais dos dois grupos com os anos tenham sido significativas, os efeitos da capacidade geral não sofreram alteração de sinal. Isto mostra que as contribuições dos efeitos aditivos dos genitores para a altura das plantas na maturação foram sempre no mesmo sentido. De modo geral, os efeitos da capacidade específica foram menores do que os observados para a capacidade geral, embora em populações como a $4 \times 7$ o efeito da capacidade específica não seja muito inferior aos das capacidades gerais.

Os efeitos das capacidades geral e especifica do caráter dias para a maturação foram baixos, sendo quase sempre inferiores a 1 (Tabela 34). Isto indica que as populações foram bastante homogêneas com relação à duração do ciclo.

Para a produção de grãos, apenas o genitor 8 possui capacidade geral positiva entre o grupo de linhagens não adaptadas, indicando que sua participação nos cruzamentos contribuiu para o aumento das médias das populações (Tabela 35). genitor 6 apresentou capacidade geral muito alta e negativa. Portanto, para este caráter ele foi o pior genitor dentro deste grupo. No grupo de linhagens adaptadas, os genitores 1 e 3 foram os que apresentam a maior e a menor capacidade geral de combinação, respectivamente. Logo, no grupo adaptado, a linhagem 3 foi a melhor genitora e a 1 foi a pior. Algumas capacidades específicas apresentam efeitos acentuados, podendo superar os efeitos da capacidade geral, como no caso da população $5 \times 7$.

Analisando os valores das capacidades gerais dos dois grupos, percebe-se que as interações com os anos foram complexas e que houve alteração do sinal dos efeitos da capacidade geral em ambos os grupos. Portanto, os efeitos aditivos de alguns genótipos podem contribuir tanto para o aumento quanto para a diminuição da 
produção de grãos, de acordo com o ambiente. O sentido mais provável de contribuição dos efeitos aditivos deve ser o verificado na análise conjunta.

Quanto ao acamamento, os efeitos da capacidade geral foram positivos para as linhagens adaptadas 2 e 5 e para as não adaptadas 7 e 8 . Isto mostra que estes genitores foram os que mais contribuíram para o aumento do acamamento nas populações (Tabela 35).

Tabela 34 Estimativas dos parâmetros obtida pela análise dialélica parcial dos caracteres altura das plantas na maturação (AM) e dias para a maturação $(D M)$, avaliados na geração $F_{2: n}$, segundo o modelo I de Griffing método 4.

\begin{tabular}{|c|c|c|c|c|c|c|c|c|}
\hline \multirow[b]{2}{*}{ Parâmetro } & \multicolumn{5}{|c|}{$\overline{A M}$} & \multicolumn{3}{|c|}{$\overline{D M}$} \\
\hline & $F_{2: 8}$ & $F_{2: 9}$ & $F_{2: 10}$ & $F_{2: 11}$ & Conjunta & $F_{2: 9}$ & $F_{2: 11}$ & Conjunta \\
\hline$\mu$ & 74,94 & 86,96 & 78,83 & 67,43 & 77,04 & 131,187 & 127,101 & 129,144 \\
\hline$g_{1}$ & $-4,96$ & $-5,89$ & $-3,36$ & $-5,85$ & $-5,01$ & 0,130 & 0,662 & 0,396 \\
\hline$g_{2}$ & 12,31 & 17,77 & 11,71 & 13,49 & 13,82 & 0,081 & 0,048 & 0,065 \\
\hline$g_{3}$ & $-2,72$ & $-1,64$ & $-1,41$ & $-2,39$ & $-2,04$ & 0,339 & 0,381 & 0,360 \\
\hline$g_{4}$ & $-0,35$ & $-4,07$ & $-1,86$ & $-1,97$ & $-2,06$ & 0,385 & $-0,079$ & 0,153 \\
\hline$g_{5}$ & $-4,28$ & $-6,17$ & $-5,08$ & $-3,28$ & $-4,71$ & $-0,935$ & $-1,012$ & $-0,973$ \\
\hline$g_{6}$ & $-8,89$ & $-13,70$ & $-9,46$ & $-11,16$ & $-10,80$ & $-0,469$ & $-1,034$ & $-0,752$ \\
\hline$g_{\gamma}$ & 1,14 & 2,50 & 3,07 & 3,35 & 2,52 & $-0,388$ & $-0,185$ & $-0,286$ \\
\hline$g_{8}$ & 7,75 & 11,20 & 6,38 & 7,81 & 8,29 & 0,857 & 1,219 & 1,038 \\
\hline$s_{16}$ & $-0,85$ & $-0,36$ & $-0,85$ & 0,41 & $-0,41$ & $-0,267$ & 0,505 & 0,119 \\
\hline$s_{17}$ & 2,89 & 2,94 & 1,37 & 3,15 & 2,59 & $-0,600$ & $-0,295$ & $-0,447$ \\
\hline $\mathrm{s}_{18}$ & $-2,04$ & $-2,58$ & $-0,52$ & $-3,55$ & $-2,18$ & 0,867 & $-0,210$ & 0,328 \\
\hline$s_{26}$ & $-2,88$ & 0,74 & $-1,88$ & $-3,48$ & $-1,88$ & $-0,330$ & $-0,815$ & $-0,572$ \\
\hline $\mathrm{S}_{28}$ & 2,88 & $-0,74$ & 1,88 & 3,48 & 1,88 & 0,330 & 0,815 & 0,572 \\
\hline$s_{36}$ & 4,54 & $-0,05$ & 2,79 & 2,35 & 2,41 & $-0,043$ & $-0,598$ & $-0,321$ \\
\hline$s_{37}$ & $-3,47$ & $-2,55$ & $-1,50$ & $-4,17$ & $-2,92$ & 0,693 & 1,036 & 0,864 \\
\hline $\mathrm{S}_{38}$ & $-1,07$ & 2,60 & $-1,28$ & 1,82 & 0,52 & $-0,649$ & $-0,438$ & $-0,544$ \\
\hline $\mathrm{S}_{46}$ & $-5,50$ & $-4,40$ & $-3,34$ & $-1,93$ & $-3,79$ & 0,385 & 0,479 & 0,432 \\
\hline$S_{47}$ & 4,70 & 5,66 & 2,70 & 2,48 & 3,89 & 0,296 & $-0,187$ & 0,055 \\
\hline $\mathrm{S}_{48}$ & 0,80 & $-1,25$ & 0,64 & $-0,55$ & $-0,09$ & $-0,681$ & $-0,291$ & $-0,486$ \\
\hline $\mathrm{S}_{56}$ & 4,68 & 4,08 & 3,29 & 2,65 & 3,67 & 0,256 & 0,429 & 0,342 \\
\hline$S_{57}$ & $-4,11$ & $-6,05$ & $-2,57$ & $-1,46$ & $-3,55$ & $-0,389$ & $-0,554$ & $-0,472$ \\
\hline$S_{58}$ & $-0,57$ & 1,98 & $-0,72$ & $-1,20$ & $-0,13$ & 0,134 & 0,125 & 0,129 \\
\hline
\end{tabular}


Tabela 35 Estimativas dos parâmetros obtida pela análise dialélica parcial dos caracteres produção de grãos (PG) e acamamento $(A C)$, avaliados na geração $F_{2: n}$, segundo o modelo I de Griffing método 4.

\begin{tabular}{|c|c|c|c|c|c|c|c|c|}
\hline \multirow[b]{2}{*}{ Parâmetro } & \multicolumn{5}{|c|}{$P G$} & \multicolumn{3}{|c|}{$\overline{A C}$} \\
\hline & $F_{2: 8}$ & $F_{2: 9}$ & $F_{2: 10}$ & $F_{2: 11}$ & Conjunta & $F_{2: 8}$ & $F_{2: 9}$ & Conjunta \\
\hline$\mu$ & 244,37 & 192,04 & 141,56 & 129,42 & 176,85 & 1,8747 & 1,8199 & 1,8473 \\
\hline$g_{1}$ & $-30,88$ & $-27,99$ & $-16,84$ & $-13,55$ & $-22,31$ & $-0,0136$ & $-0,1125$ & $-0,0630$ \\
\hline$g_{2}$ & $-20,82$ & $-1,72$ & $-16,26$ & $-3,56$ & $-10,59$ & 0,1105 & 0,0376 & 0,0741 \\
\hline$g_{3}$ & 25,22 & 20,11 & 39,71 & 15,08 & 25,03 & $-0,0790$ & $-0,1157$ & $-0,0974$ \\
\hline$g_{4}$ & 28,79 & 7,31 & 7,71 & 5,27 & 12,27 & $-0,0424$ & 0,0353 & $-0,0035$ \\
\hline$g_{5}$ & $-2,31$ & 2,29 & $-14,32$ & $-3,24$ & $-4,39$ & 0,0244 & 0,1553 & 0,0899 \\
\hline$g_{6}$ & $-54,09$ & $-11,33$ & $-10,80$ & $-18,58$ & $-23,70$ & $-0,1257$ & $-0,0345$ & $-0,0801$ \\
\hline$g_{7}$ & 5,95 & $-3,84$ & $-13,10$ & $-8,20$ & $-4,80$ & 0,0871 & $-0,0093$ & 0,0389 \\
\hline$g_{8}$ & 48,14 & 15,17 & 23,90 & 26,78 & 28,50 & 0,0386 & 0,0437 & 0,0411 \\
\hline$s_{16}$ & $-22,82$ & $-1,19$ & $-12,37$ & $-9,26$ & $-11,41$ & $-0,0024$ & 0,1602 & 0,0789 \\
\hline$S_{17}$ & 17,44 & $-0,92$ & 1,11 & 5,04 & 5,67 & 0,1049 & 0,1025 & 0,1037 \\
\hline$s_{18}$ & 5,38 & 2,11 & 11,26 & 4,22 & 5,74 & $-0,1025$ & $-0,2627$ & $-0,1826$ \\
\hline $\mathrm{s}_{26}$ & $-3,66$ & 14,53 & 1,47 & $-1,86$ & 2,62 & 0,0266 & $-0,0410$ & $-0,0072$ \\
\hline $\mathrm{S}_{28}$ & 3,66 & $-14,53$ & $-1,47$ & 1,86 & $-2,62$ & $-0,0266$ & 0,0410 & 0,0072 \\
\hline$s_{36}$ & 18,50 & $-6,09$ & 2,54 & 1,30 & 4,06 & $-0,0040$ & 0,1128 & 0,0544 \\
\hline$s_{37}$ & $-17,27$ & 2,81 & $-4,14$ & $-3,33$ & $-5,48$ & $-0,0226$ & $-0,0249$ & $-0,0237$ \\
\hline $\mathrm{S}_{38}$ & $-1,23$ & 3,27 & 1,59 & 2,03 & 1,42 & 0,0266 & $-0,0880$ & $-0,0307$ \\
\hline$S_{46}$ & $-22,23$ & $-32,37$ & $-12,52$ & 0,78 & $-16,58$ & $-0,0152$ & $-0,0878$ & $-0,0515$ \\
\hline$S_{47}$ & 23,50 & 15,02 & 10,23 & $-2,29$ & 11,61 & $-0,0535$ & $-0,0407$ & $-0,0471$ \\
\hline $\mathrm{S}_{48}$ & $-1,26$ & 17,35 & 2,29 & 1,51 & 4,97 & 0,0687 & 0,1286 & 0,0986 \\
\hline $\mathrm{S}_{56}$ & 30,21 & 25,12 & 20,88 & 9,04 & 21,31 & $-0,0049$ & $-0,1442$ & $-0,0746$ \\
\hline$S_{57}$ & $-23,67$ & $-16,91$ & $-7,20$ & 0,58 & $-11,80$ & $-0,0289$ & $-0,0369$ & $-0,0329$ \\
\hline$S_{58}$ & $-6,54$ & $-8,21$ & $-13,68$ & $-9,62$ & $-9,51$ & 0,0338 & 0,1811 & 0,1074 \\
\hline
\end{tabular}

Tanto para a altura das plantas no florescimento quanto para o número de dias para o florescimento, os efeitos aditivos medidos pela capacidade geral de combinação foram maiores no genitor 8 , o único positivo entre os genitores não adaptados (Tabela 36). Entre o grupo de genitores adaptados, os efeitos da capacidade geral de combinação foram menores e devem refletir a menor variabilidade existente entre estes genótipos com relação à ambos os caracteres.

Conforme já verificado, a interação entre a capacidade geral de combinação do grupo de genitores não adaptados com anos foi significativa no caráter altura das 
plantas no florescimento. Contudo, observando a Tabela 36 é possível verificar que as contribuições dos genótipos não adaptados foram sempre no mesmo sentido, ou seja, - genitor 8 contribuiu para aumentar a altura das plantas e os genitores 6 e 7 para reduzir.

Os efeitos da capacidade especifica de combinação nos caracteres altura das plantas no florescimento e número de dias para o florescimento, embora não significativos, apresentaram valores relativamente elevados para algumas populações.

Tabela 36. Estimativas dos parâmetros obtida pela análise dialélica parcial do caracteres altura das plantas no florescimento (AF) e dias para o florescimento (DF), avaliados na geração $F_{2: n}$, segundo o modelo 1 de Griffing método 4.

\begin{tabular}{|c|c|c|c|c|c|c|c|c|}
\hline \multirow[b]{2}{*}{ Parâmetro } & \multicolumn{4}{|c|}{$\mathrm{AF}$} & \multicolumn{4}{|c|}{ DF } \\
\hline & $F_{2: 9}$ & $F_{2: 10}$ & $F_{2: 11}$ & Conjunta & $F_{29}$ & $F_{2: 10}$ & $\mathrm{~F}_{2: 11}$ & Conjunta \\
\hline$\mu$ & 60,61 & 62,52 & 46,90 & 56,67 & 60,21 & 52,13 & 51,91 & 54,75 \\
\hline$g_{1}$ & $-2,67$ & $-0,43$ & $-1,38$ & $-1,49$ & 0,54 & 0,36 & 0,75 & 0,55 \\
\hline$g_{2}$ & 3,40 & 4,93 & 0,27 & 2,87 & $-0,46$ & 0,49 & $-0,29$ & $-0,08$ \\
\hline$g_{3}$ & 2,01 & $-0,56$ & 1,37 & 0,94 & 0,22 & $-1,43$ & 0,70 & $-0,17$ \\
\hline$g_{4}$ & $-0,14$ & 0,80 & 0,55 & 0,40 & 0,68 & 1,09 & 0,35 & 0,71 \\
\hline$g_{5}$ & $-2,60$ & $-4,74$ & $-0,81$ & $-2,72$ & $-0,99$ & $-0,52$ & $-1,51$ & $-1,01$ \\
\hline $\mathrm{g}_{6}$ & $-4,19$ & $-5,28$ & $-5,22$ & $-4,90$ & $-2,40$ & $-2,19$ & $-2,10$ & $-2,23$ \\
\hline$g_{7}$ & $-5,68$ & $-6,02$ & $-1,16$ & $-4,29$ & $-1,42$ & $-1,42$ & $-0,91$ & $-1,25$ \\
\hline$g_{8}$ & 9,87 & 11,30 & 6,39 & 9,19 & 3,81 & 3,60 & 3,01 & 3,48 \\
\hline$s_{16}$ & $-2,31$ & $-2,18$ & 1,16 & $-1,11$ & 0,16 & 1,26 & 1,95 & 1,12 \\
\hline $\mathbf{s}_{17}$ & 2,10 & 2,43 & 0,82 & 1,78 & 0,27 & 0,61 & 0,01 & 0,30 \\
\hline $\mathrm{s}_{18}$ & 0,21 & $-0,25$ & $-1,98$ & $-0,67$ & $-0,43$ & $-1,87$ & $-1,96$ & $-1,42$ \\
\hline $\mathrm{s}_{26}$ & 2,40 & $-2,52$ & $-0,22$ & $-0,11$ & 0,01 & 0,05 & $-0,67$ & $-0,20$ \\
\hline $\mathrm{s}_{28}$ & $-2,40$ & 2,52 & 0,22 & 0,11 & $-0,01$ & $-0,05$ & 0,67 & 0,20 \\
\hline$s_{36}$ & $-0,91$ & 2,73 & 0,42 & 0,75 & 0,86 & $-0,59$ & 0,81 & 0,36 \\
\hline$s_{37}$ & $-0,26$ & $-1,96$ & $-1,31$ & $-1,17$ & $-0,35$ & 0,01 & $-0,04$ & $-0,13$ \\
\hline$S_{38}$ & 1,16 & $-0,77$ & 0,89 & 0,43 & $-0,51$ & 0,58 & $-0,78$ & $-0,23$ \\
\hline $\mathrm{S}_{46}$ & $-3,12$ & $-2,51$ & $-2,28$ & $-2,64$ & $-0,73$ & $-0,77$ & $-1,83$ & $-1,11$ \\
\hline $\mathrm{S}_{47}$ & 0,04 & 4,01 & 0,06 & 1,37 & 0,02 & 0,31 & 1,04 & 0,46 \\
\hline $\mathrm{S}_{48}$ & 3,08 & $-1,49$ & 2,22 & 1,27 & 0,71 & 0,46 & 0,79 & 0,65 \\
\hline$S_{56}$ & 3,94 & 4,48 & 0,92 & 3,11 & $-0,29$ & 0,04 & $-0,27$ & $-0,17$ \\
\hline$S_{57}$ & $-1,88$ & $-4,48$ & 0,43 & $-1,98$ & 0,06 & $-0,92$ & $-1,02$ & $-0,63$ \\
\hline$S_{58}$ & $-2,06$ & 0,00 & $-1,34$ & $-1,14$ & 0,23 & 0,88 & 1,29 & 0,80 \\
\hline
\end{tabular}


4.8 Análises de variância de progênies dentro de populações e estimativas da variância genética dentro de populações.

As análises de variâncias mostraram que existem diferenças entre as progênies de uma mesma população para maioria dos caracteres (Tabelas 80 a 85 - Apêndice). O caráter acamamento foi o que apresentou maior número de populações com progênies homogêneas. A interação genótipos vs. ambiente foi significativa para a maioria das populações em todos os caracteres, à exceção de acamamento.

Pelas esperanças dos quadrados médios das análises de variâncias das progênies dentro das populações foi possivel estimar a variância genética existente entre as progênies de cada população (Tabelas 37, 38 e 39). As estimativas da variância genética que apresentaram valores negativos foram consideradas nulas. Como se tratam de populações endogâmicas, estas estimativas contém efeitos aditivos e epistáticos do tipo aditivo $x$ aditivo e de ordens mais elevadas (Kearsey \& Pooni, 1996). Como as progênies foram conduzidas pelo método da amostra dentro de progênies e não foram abertas linhagens, podemos estimar pela metodologia de Cockerham que uma porção idêntica da variância genética existente nas populações está contida dentro das progênies (Ramalho \& Vencovsky, 1979; Vello, 1985).

As variâncias genéticas dentro das populações estimadas para os caracteres altura das plantas na maturação e produção de grãos já haviam sido obtidas por Pulcinelli (1997). As pequenas alterações encontradas neste trabalho e no desenvolvido pelo autor se devem a pequenos ajustes realizados. Estas análises foram repetidas apenas para facilitar o entendimento do comportamento das populações nestes dois caracteres. Logo, os créditos a respeito das estimativas das variâncias genéticas para a produção de grãos e para a altura das plantas na maturação devem ser atribuídos a Pulcinelli (1997).

A interação genótipo vs. ambiente foi significativa para boa parte das análises de variâncias realizadas, portanto podemos concluir que as melhores estimativas das variâncias genéticas foram obtidas pela análise conjunta, que são isentas dos efeitos da interação dos genótipos com o ambiente (Vencovsky \& Barriga, 1992).

Observando as Tabelas 86 a 90 (Apêndice), verificamos que os intervalos de confiança associados às estimavas de variância genética foram altos para uma parte 
considerável das populações em todos os caracteres. Isto implica que a precisão das estimativas de variância genética foi baixa (Barbin, 1993).

Lembrando que as progênies foram avaliadas em parcelas de uma linha de um metro e que apenas três repetições foram utilizadas, podemos verificar que as condições experimentais devem ter sido as principais responsáveis pela baixa confiabilidade das variâncias genéticas. Para que as estimativas fossem mais precisas seria necessário que o tamanho da parcela e o número de repetições fossem maiores.

As estimativas de variância utilizadas neste estudo foram obtidas a partir de 20 progênies. Cada progênie descende de um único individuo $F_{2}$. Como a progênie contém no máximo a mesma variabilidade presente na planta $F_{2}$ original, toda a variabilidade existente entre duas linhagens genitoras está representada por apenas 20 plantas $F_{2}$. Gumber et al. (1999) sugerem que boas estimativas de variância genética em gerações com nivel de endogamia elevado são obtidas utilizando mais de 100 linhagens. Considerando que apenas 20 progênies foram utilizadas, cada população está representada por um número de progênies abaixo do recomendado para a obtenção de estimativas isentas dos efeitos da deriva.

O método de condução por amostra dentro de progênies submete as populações à seleção natural. A seleção natural atua no sentido de aumentar a freqüência de individuos mais adaptados às condições ambientais, que devem produzir mais sementes e estarão melhor representados na amostra aleatória de sementes realizada para compor a progênie na geração seguinte (Fehr, 1987).

Como descrito no capitulo anterior, as populações foram conduzidas entre $F_{2: 3} \mathrm{e}$ $F_{2: 7}$ segundo o método da amostra dentro de progênies. A partir de $F_{2: 8}$ foram realizadas avaliações em experimentos, mas o processo de obtenção das sementes para compor as gerações $F_{2: 8}$ a $F_{2: 11}$ não diferiu do realizado nas gerações com endogamia mais baixa. Portanto, durante oito gerações as progênies estiveram sujeitas à esta seleção natural. Isto deve ter causado um viés no sentido das plantas mais produtivas, sendo provavelmente maior nas progênies que apresentaram maior variabilidade quanto ao número de sementes produzidas. Nos demais caracteres a seleção natural pode ter atuado de modo indireto, sendo tanto maior seu nivel de atuação quanto maior for a correlação de um dado caráter com o componente de produção número de sementes por planta. 
Logo, as estimativas de variância genética tiveram baixa precisão em função das condições experimentais utilizadas e devem apresentar um viés devido ao pequeno número de progênies utilizadas e pela maneira como foram conduzidas.

Tabela 37. Estimativa da variância genética entre progênies dentro de cada população, para o caráter altura das plantas na maturação dias para maturação.

\begin{tabular}{|c|c|c|c|c|c|c|c|c|}
\hline \multirow[b]{2}{*}{ População } & \multicolumn{5}{|c|}{ Altura das plantas na maturação } & \multicolumn{3}{|c|}{ Dias para maturação } \\
\hline & $F_{2: 8}$ & $F_{2: 9}$ & $F_{2: 10}$ & $F_{2: 11}$ & Conjunta & $F_{2: 9}$ & $F_{2: 11}$ & Conjunta \\
\hline $1 \times 2$ & 138,89 & 208,92 & 89,98 & 176,81 & 105,27 & 0,73 & 0,73 & 0,90 \\
\hline $1 \times 3$ & 31,13 & 37,64 & 33,36 & 70,07 & 35,72 & 2,11 & 0,74 & 0,92 \\
\hline $1 \times 4$ & 54,67 & 60,40 & 40,54 & 36,16 & 36,68 & 0,00 & 6,87 & 0,00 \\
\hline $1 \times 6$ & 11,96 & 67,28 & 90,90 & 60,04 & 22,65 & 0,00 & 7,11 & 2,32 \\
\hline $1 \times 7$ & 2,77 & 137,79 & 47,87 & 149,99 & 68,00 & 0,79 & 2,17 & 1,49 \\
\hline $1 \times 8$ & 54,25 & 44,50 & 31,07 & 1,50 & 23,40 & 4,28 & 2,44 & 1,91 \\
\hline $2 \times 3$ & 120,02 & 328,96 & 103,42 & 131,78 & 104,90 & 0,87 & 7,58 & 0,84 \\
\hline $2 \times 4$ & 230,27 & 288,52 & 153,38 & 161,15 & 162,52 & 0,11 & 5,47 & 1,91 \\
\hline $2 \times 5$ & 249,18 & 366,91 & 37,55 & 181,46 & 222,72 & 0,53 & 8,27 & 0,00 \\
\hline $2 \times 6$ & 34,34 & 94,39 & 137,05 & 118,73 & 69,45 & 0,00 & 1,66 & 0,91 \\
\hline $2 \times 8$ & 107,05 & 118,56 & 68,84 & 270,66 & 77,33 & 0,00 & 0,44 & 0,00 \\
\hline $3 \times 5$ & 71,70 & 49,11 & 50,44 & 26,95 & 32,69 & 1,33 & 9,84 & 3,27 \\
\hline $3 \times 6$ & 82,06 & 42,90 & 46,69 & 21,14 & 52,69 & 0,00 & 10,63 & 3,14 \\
\hline $3 \times 7$ & 127,61 & 412,54 & 140,43 & 145,49 & 175,65 & 0,00 & 0,00 & 2,52 \\
\hline $3 \times 8$ & 96,02 & 184,30 & 83,28 & 55,41 & 87,74 & 0,03 & 7,25 & 2,95 \\
\hline $4 \times 5$ & 37,96 & 35,87 & 23,53 & 22,17 & 21,17 & 0,53 & 3,74 & 1,08 \\
\hline $4 \times 6$ & 102,15 & 276,55 & 194,69 & 137,43 & 131,50 & 0,00 & 14,45 & 4,69 \\
\hline $4 \times 7$ & 152,80 & 237,44 & 49,91 & 158,18 & 136,42 & 0,00 & 1,08 & 0,57 \\
\hline $4 \times 8$ & 38,80 & 97,55 & 29,82 & 23,27 & 43,76 & 0,09 & 1,75 & 1,38 \\
\hline $5 \times 6$ & 0,00 & 26,41 & 36,23 & 23,00 & 14,16 & 0,45 & 7,60 & 2,10 \\
\hline $5 \times 7$ & 117,49 & 375,47 & 160,04 & 103,46 & 122,60 & 0,63 & 7,00 & 1,60 \\
\hline $5 \times 8$ & 19,83 & 315,64 & 73,25 & 101,58 & 78,11 & 0,00 & 3,96 & 2,05 \\
\hline $6 \times 7$ & 96,04 & 256,11 & 128,47 & 217,59 & 121,35 & 0,58 & 3,85 & 2,01 \\
\hline $6 \times 8$ & 32,04 & 287,37 & 40,95 & 90,62 & 81,42 & 1,22 & 4,97 & 2,83 \\
\hline $7 \times 8$ & 81,20 & 242,49 & 0,72 & 129,58 & 65,01 & 0,00 & 1,46 & 0,47 \\
\hline
\end{tabular}


Tabela 38. Estimativa da variância genética existente entre progênies dentro de cada população, para caráter produção de grãos e acamamento (transformado por $\sqrt{\mathrm{x}+1}$ ).

\begin{tabular}{|c|c|c|c|c|c|c|c|c|}
\hline \multirow[b]{2}{*}{ População } & \multicolumn{5}{|c|}{ Produção de grãos } & \multicolumn{3}{|c|}{ Acamamento } \\
\hline & $F_{2: 8}$ & $F_{2: 9}$ & $F_{2: 10}$ & $F_{2: 11}$ & Conjunta & $\mathrm{F}_{2: 8}$ & $F_{2: 9}$ & Conjunta \\
\hline $1 \times 2$ & 1842,211 & 1601,933 & 0,000 & 1186,748 & 143,455 & 0,000 & 0,000 & 0,005 \\
\hline $1 \times 3$ & 1033,558 & 2258,934 & 978,109 & 1024,062 & 1100,347 & 0,014 & 0,200 & 0,004 \\
\hline $1 \times 4$ & 9104,393 & 6435,214 & 3606,921 & 1773,986 & 3388,436 & 0,013 & 0,054 & 0,004 \\
\hline $1 \times 6$ & 641,816 & 1631,755 & 1533,229 & 891,857 & 551,368 & 0,000 & 0,368 & 0,006 \\
\hline $1 \times 7$ & 693,383 & 108,216 & 281,719 & 115,062 & 184,413 & 0,002 & 0,789 & 0,020 \\
\hline $1 \times 8$ & 659,350 & 448,048 & 430,915 & 544,630 & 175,481 & 0,001 & 0,584 & 0,001 \\
\hline $2 \times 3$ & 4126,453 & 1639,229 & 0,000 & 77,867 & 1148,682 & 0,000 & 0,000 & 0,001 \\
\hline $2 \times 4$ & 2473,906 & 1621,658 & 1533,389 & 1202,663 & 1456,550 & 0,007 & 0,147 & 0,008 \\
\hline $2 \times 5$ & 2125,488 & 918,129 & 965,367 & 827,510 & 1721,709 & 0,013 & 0,253 & 0,022 \\
\hline $2 \times 6$ & 2346,305 & 1538,824 & 629,643 & 836,009 & 850,642 & 0,000 & 0,568 & 0,011 \\
\hline $2 \times 8$ & 817,189 & 5,977 & 1832,758 & 505,157 & 471,897 & 0,005 & 0,042 & 0,007 \\
\hline $3 \times 5$ & 2928,953 & 2417,352 & 1302,106 & 588,768 & 1524,294 & 0,000 & 0,000 & 0,003 \\
\hline $3 \times 6$ & 2986,179 & 879,418 & 1495,796 & 872,388 & 1345,756 & 0,005 & 0,042 & 0,006 \\
\hline $3 \times 7$ & 2713,177 & 2610,697 & 722,545 & 1366,407 & 1854,021 & 0,031 & 0,355 & 0,017 \\
\hline $3 \times 8$ & 793,716 & 1708,519 & 1972,302 & 856,102 & 1057,045 & 0,000 & 0,126 & 0,005 \\
\hline $4 \times 5$ & 3510,561 & 3797,727 & 1195,737 & 0,000 & 1133,931 & 0,002 & 0,305 & 0,002 \\
\hline $4 \times 6$ & 6434,106 & 3055,400 & 1190,683 & 2078,686 & 2248,983 & 0,029 & 0,025 & 0,025 \\
\hline $4 \times 7$ & 587,796 & 1601,386 & 552,097 & 942,339 & 786,758 & 0,028 & 0,171 & 0,033 \\
\hline $4 \times 8$ & 356,853 & 0,000 & 477,814 & 0,000 & 4,740 & 0,000 & 0,013 & 0,002 \\
\hline $5 \times 6$ & 3454,056 & 1299,764 & 2566,069 & 1655,429 & 1261,135 & 0,000 & 0,000 & 0,007 \\
\hline $5 \times 7$ & 1333,670 & 1030,799 & 790,572 & 1346,163 & 517,561 & 0,018 & 0,258 & 0,021 \\
\hline $5 \times 8$ & 0,000 & 882,464 & 563,339 & 81,634 & 444,541 & 0,000 & 0,553 & 0,004 \\
\hline $6 \times 7$ & 2975,663 & 5108,136 & 3289,636 & 1180,807 & 2493,106 & 0,027 & 1,334 & 0,018 \\
\hline $6 \times 8$ & 4214,047 & 3216,289 & 1233,595 & 740,469 & 1434,902 & 0,023 & 0,245 & 0,026 \\
\hline $7 \times 8$ & 1287,007 & 270,022 & 525,532 & 1809,465 & 666,402 & 0,012 & 0,000 & 0,006 \\
\hline
\end{tabular}


Tabela 39. Estimativa da variância genética entre progênies dentro de cada população, para altura das plantas no florescimento e dias para o florescimento.

\begin{tabular}{|c|c|c|c|c|c|c|c|c|}
\hline \multirow[b]{2}{*}{ População } & \multicolumn{4}{|c|}{ Altura das plantas no florescimento } & \multicolumn{4}{|c|}{ Dias para o florescimento } \\
\hline & $F_{2 \cdot 9}$ & $F_{2: 10}$ & $F_{2: 11}$ & Conjunta & $F_{2: 9}$ & $F_{2: 10}$ & $F_{2: 11}$ & Conjunta \\
\hline $1 \times 2$ & 12,31 & 48,75 & 0,00 & 18,93 & 6,18 & 2,14 & 6,54 & 4,57 \\
\hline $1 \times 3$ & 9,68 & 43,42 & 23,82 & 22,84 & 6,23 & 1,73 & 13,06 & 3,06 \\
\hline $1 \times 4$ & 16,71 & 41,56 & 10,27 & 9,33 & 0,04 & 0,89 & 6,14 & 1,43 \\
\hline $1 \times 5$ & 37,28 & 86,16 & 21,44 & 20,19 & 1,61 & 3,17 & 5,84 & 2,41 \\
\hline $1 \times 7$ & 28,45 & 148,84 & 27,32 & 15,25 & 6,26 & 5,20 & 9,11 & 5,99 \\
\hline $1 \times 8$ & 39,06 & 44,73 & 0,00 & 6,68 & 4,89 & 5,46 & 5,53 & 4,10 \\
\hline $2 \times 3$ & 17,37 & 39,45 & 7,31 & 6,79 & 3,26 & 7,48 & 9,16 & 4,48 \\
\hline $2 \times 4$ & 17,40 & 65,50 & 11,60 & 15,95 & 0,22 & 2,59 & 3,06 & 1,54 \\
\hline $2 \times 5$ & 26,57 & 78,30 & 19,88 & 33,60 & 0,30 & 8,16 & 10,09 & 4,97 \\
\hline $2 \times 6$ & 12,40 & 56,65 & 17,38 & 14,11 & 0,66 & 5,38 & 7,21 & 3,10 \\
\hline $2 \times 8$ & 97,37 & 118,23 & 23,67 & 0,00 & 12,01 & 1,11 & 5,53 & 4,43 \\
\hline $3 \times 5$ & 0,00 & 32,82 & 8,30 & 12,38 & 0,95 & 1,26 & 7,89 & 3,11 \\
\hline $3 \times 6$ & 23,88 & 70,58 & 24,89 & 29,24 & 13,58 & 6,41 & 12,68 & 7,98 \\
\hline $3 \times 7$ & 35,58 & 10,61 & 10,62 & 21,64 & 1,88 & 0,00 & 2,54 & 2,59 \\
\hline $3 \times 8$ & 60,51 & 117,60 & 48,23 & 57,12 & 11,16 & 13,73 & 11,00 & 11,48 \\
\hline $4 \times 5$ & 1,51 & 41,27 & 14,44 & 15,36 & 2,67 & 2,18 & 8,02 & 4,17 \\
\hline $4 \times 6$ & 46,78 & 61,80 & 49,30 & 59,82 & 1,99 & 7,14 & 15,82 & 7,31 \\
\hline $4 \times 7$ & 23,77 & 193,11 & 27,07 & 32,79 & 4,73 & 5,14 & 10,60 & 5,56 \\
\hline $4 \times 8$ & 99,78 & 61,56 & 29,64 & 33,25 & 2,80 & 7,25 & 1,24 & 2,31 \\
\hline $5 \times 6$ & 7,21 & 19,48 & 17,94 & 2,33 & 0,67 & 0,09 & 7,39 & 1,13 \\
\hline $5 \times 7$ & 21,46 & 9,31 & 8,73 & 3,58 & 0,11 & 2,87 & 10,52 & 2,88 \\
\hline $5 \times 8$ & 44,29 & 31,27 & 35,00 & 43,23 & 5,68 & 0,00 & 9,75 & 6,64 \\
\hline $6 \times 7$ & 26,23 & 57,20 & 17,96 & 29,44 & 2,18 & 0,95 & 4,08 & 2,58 \\
\hline $6 \times 8$ & 26,79 & 89,29 & 24,15 & 27,14 & 4,82 & 17,60 & 16,14 & 11,96 \\
\hline $7 \times 8$ & 40,82 & 52,71 & 21,15 & 25,57 & 6,23 & 0,11 & 11,42 & 4,16 \\
\hline
\end{tabular}

4.9 Proporção de progênies superiores observadas nas populações

As populações variaram muito com relação à proporção de progênies superiores à média das 493 progênies estudadas (Tabelas 40, 41 e 42). Em todos os caracteres houveram populações em que todas as progênies apresentavam média abaixo ou acima da média geral. Foi verificada certa consistência entre as proporções de progênies superiores observadas em anos diferentes. 
Tabela 40. Proporção de progênies superiores observadas para os caracteres altura das plantas na maturação e dias para a maturação.

\begin{tabular}{|c|c|c|c|c|c|c|c|c|}
\hline \multirow[b]{2}{*}{ População } & \multicolumn{5}{|c|}{ Altura das plantas na maturação } & \multicolumn{3}{|c|}{ Dias para maturação } \\
\hline & $\mathrm{F}_{2: 8}$ & $\overline{F_{2: 9}}$ & $\mathrm{~F}_{2: 10}$ & $F_{2: 11}$ & Conjunta & $F_{2: 9}$ & $F_{2: 11}$ & Conjunta \\
\hline $1 \times 2$ & 0,65 & 0,55 & 0,75 & 0,68 & 0,70 & 0,40 & 1,00 & 0,70 \\
\hline $1 \times 3$ & 0,10 & 0,05 & 0,10 & 0,40 & 0,10 & 0,80 & 0,90 & 0,90 \\
\hline $1 \times 4$ & 0,08 & 0,00 & 0,08 & 0,08 & 0,00 & 0,31 & 0,54 & 0,38 \\
\hline $1 \times 6$ & 0,05 & 0,05 & 0,10 & 0,10 & 0,00 & 0,50 & 0,70 & 0,50 \\
\hline $1 \times 7$ & 0,55 & 0,55 & 0,70 & 0,60 & 0,50 & 0,05 & 0,60 & 0,10 \\
\hline $1 \times 8$ & 0,60 & 0,75 & 0,70 & 0,50 & 0,75 & 0,40 & 0,90 & 0,75 \\
\hline $2 \times 3$ & 0,70 & 0,40 & 0,45 & 0,55 & 0,55 & 0,90 & 0,65 & 0,75 \\
\hline $2 \times 4$ & 0,65 & 0,70 & 0,60 & 0,80 & 0,70 & 0,90 & 0,65 & 0,85 \\
\hline $2 \times 5$ & 0,75 & 0,60 & 0,55 & 0,75 & 0,70 & 0,90 & 0,60 & 0,65 \\
\hline $2 \times 6$ & 0,45 & 0,65 & 0,60 & 0,55 & 0,55 & 0,00 & 0,15 & 0,05 \\
\hline $2 \times 8$ & 1,00 & 0,95 & 0,95 & 0,95 & 0,95 & 0,60 & 1,00 & 1,00 \\
\hline $3 \times 5$ & 0,10 & 0,00 & 0,05 & 0,25 & 0,05 & 0,90 & 0,50 & 0,55 \\
\hline $3 \times 6$ & 0,25 & 0,10 & 0,35 & 0,10 & 0,10 & 0,40 & 0,45 & 0,40 \\
\hline $3 \times 7$ & 0,45 & 0,60 & 0,60 & 0,40 & 0,50 & 0,55 & 0,70 & 0,65 \\
\hline $3 \times 8$ & 0,65 & 0,80 & 0,75 & 0,74 & 0,80 & 0,45 & 0,68 & 0,70 \\
\hline $4 \times 5$ & 0,10 & 0,05 & 0,15 & 0,15 & 0,05 & 0,90 & 0,55 & 0,65 \\
\hline $4 \times 6$ & 0,10 & 0,15 & 0,10 & 0,20 & 0,15 & 0,70 & 0,60 & 0,50 \\
\hline $4 \times 7$ & 0,70 & 0,75 & 0,70 & 0,65 & 0,70 & 0,35 & 0,40 & 0,20 \\
\hline $4 \times 8$ & 0,80 & 0,75 & 0,80 & 0,80 & 0,90 & 0,50 & 0,75 & 0,60 \\
\hline $5 \times 6$ & 0,10 & 0,05 & 0,10 & 0,05 & 0,00 & 0,00 & 0,40 & 0,05 \\
\hline $5 \times 7$ & 0,30 & 0,45 & 0,45 & 0,55 & 0,40 & 0,05 & 0,50 & 0,15 \\
\hline $5 \times 8$ & 0,70 & 0,65 & 0,50 & 0,65 & 0,70 & 0,90 & 0,65 & 0,70 \\
\hline $6 \times 7$ & 0,45 & 0,30 & 0,40 & 0,35 & 0,35 & 0,50 & 0,60 & 0,55 \\
\hline $6 \times 8$ & 0,75 & 0,75 & 0,80 & 0,40 & 0,65 & 0,40 & 0,40 & 0,35 \\
\hline $7 \times 8$ & 0,90 & 0,90 & 0,95 & 0,90 & 0,95 & 0,25 & 0,65 & 0,55 \\
\hline
\end{tabular}


Tabela 41. Proporção de progênies superiores observadas para os caracteres produção de grãos e acamamento.

\begin{tabular}{|c|c|c|c|c|c|c|c|c|}
\hline \multirow[b]{2}{*}{ População } & \multicolumn{5}{|c|}{ Produção de grãos } & \multicolumn{3}{|c|}{ Acamamento } \\
\hline & $\mathrm{F}_{2: 8}$ & $F_{2: 9}$ & $\mathrm{~F}_{2: 10}$ & $F_{2: 11}$ & Conjunta & $F_{29}$ & $F_{211}$ & Conjunta \\
\hline $1 \times 2$ & 0,45 & 0,75 & 0,85 & 0,47 & 0,70 & 0,00 & 0,05 & 0,00 \\
\hline $1 \times 3$ & 0,80 & 0,70 & 0,80 & 0,90 & 0,90 & 0,10 & 0,40 & 0,15 \\
\hline $1 \times 4$ & 0,62 & 0,62 & 0,85 & 0,77 & 0,69 & 0,15 & 0,08 & 0,08 \\
\hline $1 \times 6$ & 0,00 & 0,00 & 0,15 & 0,10 & 0,00 & 0,10 & 0,65 & 0,40 \\
\hline $1 \times 7$ & 0,30 & 0,20 & 0,00 & 0,15 & 0,10 & 0,90 & 0,75 & 0,85 \\
\hline $1 \times 8$ & 0,55 & 0,25 & 0,50 & 0,60 & 0,50 & 0,35 & 0,75 & 0,70 \\
\hline $2 \times 3$ & 0,70 & 0,70 & 0,90 & 0,90 & 0,85 & 0,10 & 0,25 & 0,10 \\
\hline $2 \times 4$ & 0,75 & 0,70 & 0,45 & 0,90 & 0,80 & 0,20 & 0,20 & 0,20 \\
\hline $2 \times 5$ & 0,60 & 0,85 & 0,25 & 0,70 & 0,60 & 0,20 & 0,40 & 0,25 \\
\hline $2 \times 6$ & 0,10 & 0,35 & 0,15 & 0,15 & 0,05 & 0,50 & 0,55 & 0,50 \\
\hline $2 \times 8$ & 0,50 & 0,45 & 0,50 & 0,70 & 0,50 & 0,75 & 0,95 & 0,95 \\
\hline $3 \times 5$ & 0,80 & 0,80 & 0,65 & 0,90 & 0,85 & 0,00 & 0,15 & 0,00 \\
\hline $3 \times 6$ & 0,20 & 0,50 & 0,65 & 0,30 & 0,30 & 0,05 & 0,35 & 0,10 \\
\hline $3 \times 7$ & 0,50 & 0,45 & 0,60 & 0,25 & 0,45 & 0,40 & 0,75 & 0,60 \\
\hline $3 \times 8$ & 0,75 & 0,55 & 0,75 & 0,74 & 0,90 & 0,30 & 0,70 & 0,40 \\
\hline $4 \times 5$ & 0,95 & 0,70 & 0,95 & 1,00 & 1,00 & 0,00 & 0,45 & 0,20 \\
\hline $4 \times 6$ & 0,25 & 0,15 & 0,35 & 0,30 & 0,25 & 0,15 & 0,20 & 0,15 \\
\hline $4 \times 7$ & 0,85 & 0,40 & 0,45 & 0,30 & 0,50 & 0,55 & 0,65 & 0,65 \\
\hline $4 \times 8$ & 0,90 & 0,70 & 0,75 & 0,80 & 0,95 & 0,70 & 0,75 & 0,80 \\
\hline $5 \times 6$ & 0,30 & 0,35 & 0,45 & 0,35 & 0,20 & 0,15 & 0,15 & 0,10 \\
\hline $5 \times 7$ & 0,25 & 0,20 & 0,15 & 0,30 & 0,20 & 0,65 & 0,50 & 0,50 \\
\hline $5 \times 8$ & 0,95 & 0,50 & 0,30 & 0,70 & 0,60 & 0,75 & 0,75 & 0,80 \\
\hline $6 \times 7$ & 0,15 & 0,15 & 0,20 & 0,05 & 0,20 & 0,65 & 0,55 & 0,60 \\
\hline $6 \times 8$ & 0,50 & 0,20 & 0,25 & 0,10 & 0,25 & 0,90 & 0,95 & 0,95 \\
\hline $7 \times 8$ & 0,20 & 0,15 & 0,05 & 0,10 & 0,10 & 1,00 & 1,00 & 1,00 \\
\hline
\end{tabular}


Tabela 42. Proporção de progênies superiores observadas para os caracteres altura das plantas no florescimento e dias para o florescimento.

\begin{tabular}{|c|c|c|c|c|c|c|c|c|}
\hline \multirow[b]{2}{*}{ População } & \multicolumn{4}{|c|}{ Altura das plantas no florescimento } & \multicolumn{4}{|c|}{ Dias para o florescimento } \\
\hline & $F_{2: 9}$ & $\mathrm{~F}_{2: 10}$ & $F_{2: 11}$ & Conjunta & $\mathrm{F}_{2: 9}$ & $F_{2: 10}$ & $F_{2: 11}$ & conjunta \\
\hline $1 \times 2$ & 0,15 & 0,55 & 0,16 & 0,35 & 0,15 & 0,05 & 0,21 & 0,15 \\
\hline $1 \times 3$ & 0,40 & 0,70 & 0,45 & 0,55 & 0,20 & 0,15 & 0,60 & 0,30 \\
\hline $1 \times 4$ & 0,08 & 0,08 & 0,15 & 0,00 & 0,00 & 0,00 & 0,38 & 0,00 \\
\hline $1 \times 5$ & 0,25 & 0,35 & 0,10 & 0,25 & 0,15 & 0,40 & 0,65 & 0,45 \\
\hline $1 \times 7$ & 0,15 & 0,40 & 0,25 & 0,25 & 0,40 & 0,30 & 0,45 & 0,35 \\
\hline $1 \times 8$ & 0,85 & 0,85 & 0,60 & 0,90 & 0,90 & 0,80 & 0,80 & 0,80 \\
\hline $2 \times 3$ & 0,45 & 0,70 & 0,35 & 0,55 & 0,10 & 0,50 & 0,45 & 0,40 \\
\hline $2 \times 4$ & 0,60 & 0,20 & 0,55 & 0,30 & 0,00 & 0,25 & 0,25 & 0,15 \\
\hline $2 \times 5$ & 0,50 & 0,35 & 0,30 & 0,30 & 0,05 & 0,30 & 0,10 & 0,20 \\
\hline $2 \times 6$ & 0,55 & 0,35 & 0,10 & 0,30 & 0,00 & 0,40 & 0,15 & 0,10 \\
\hline $2 \times 8$ & 0,85 & 0,95 & 0,80 & 1,00 & 0,80 & 1,00 & 0,95 & 0,95 \\
\hline $3 \times 5$ & 0,70 & 0,10 & 0,25 & 0,15 & 0,00 & 0,05 & 0,10 & 0,05 \\
\hline $3 \times 6$ & 0,25 & 0,35 & 0,25 & 0,25 & 0,15 & 0,15 & 0,60 & 0,15 \\
\hline $3 \times 7$ & 0,45 & 0,40 & 0,30 & 0,45 & 0,20 & 0,15 & 0,40 & 0,20 \\
\hline $3 \times 8$ & 1,00 & 0,90 & 0,58 & 0,90 & 0,80 & 0,75 & 0,79 & 0,85 \\
\hline $4 \times 5$ & 0,30 & 0,15 & 0,35 & 0,25 & 0,20 & 0,15 & 0,30 & 0,25 \\
\hline $4 \times 6$ & 0,15 & 0,25 & 0,10 & 0,15 & 0,10 & 0,25 & 0,25 & 0,10 \\
\hline $4 \times 7$ & 0,15 & 0,40 & 0,15 & 0,25 & 0,30 & 0,25 & 0,65 & 0,40 \\
\hline $4 \times 8$ & 0,90 & 0,95 & 0,90 & 0,95 & 1,00 & 0,95 & 1,00 & 1,00 \\
\hline $5 \times 6$ & 0,35 & 0,30 & 0,05 & 0,15 & 0,00 & 0,00 & 0,15 & 0,00 \\
\hline $5 \times 7$ & 0,05 & 0,05 & 0,20 & 0,00 & 0,05 & 0,15 & 0,25 & 0,15 \\
\hline $5 \times 8$ & 0,75 & 0,85 & 0,60 & 0,75 & 0,75 & 1,00 & 0,80 & 0,90 \\
\hline $6 \times 7$ & 0,20 & 0,30 & 0,00 & 0,15 & 0,10 & 0,35 & 0,30 & 0,25 \\
\hline $6 \times 8$ & 0,85 & 0,85 & 0,45 & 0,90 & 0,75 & 0,90 & 0,85 & 0,85 \\
\hline $7 \times 8$ & 0,80 & 0,70 & 0,70 & 0,80 & 0,85 & 1,00 & 0,85 & 1,00 \\
\hline
\end{tabular}


Para o caráter produção de grãos, as populações em que as linhagens 6 e 7 foram usadas como genitoras tenderam a apresentar as menores proporções de progênies superiores e as linhagens 3 e 4 as maiores. Entre as cinco populações com maior proporção de progênies superiores, duas foram formadas utilizando a linhagem 8 como genitora ( $3 \times 8$ e $4 \times 8$ ). Portanto, neste conjunto fixo de populações, o uso de um genitor não adaptado nem sempre resultou em populações com baixo potencial.

Populações de soja formadas a partir do cruzamento entre genitores adaptados e não adaptados com potencial semelhante às populações formadas exclusivamente por genitores adaptados também foram verificadas por outros autores (Prado, 1999; Gieco, 1997; Scott \& Kephard, 1997). Contudo, outros trabalhos mostraram que a utilização de genitores não adaptados gerou populações com baixo potencial para o melhoramento para a produção de grãos (Ininda et al.1996; Vello et al., 1984; Schoener \& Fehr, 1979; Thorne \& Fehr, 1970). Como todos estes trabalhos foram realizados utilizando conjuntos fixos de genótipos, as diferenças existentes entre os genitores podem ter ocasionado estes resultados conflitantes.

Quando as linhagens 2, 7 e 8 foram utilizadas como genitoras, as populações tenderam a serem mais altas no final do ciclo e a apresentarem maior acamamento. As populações descendentes da linhagem 8 foram as que apresentaram maiores período vegetativo, ciclo e altura no florescimento.

Os coeficientes de correlação entre a proporção de progênies superiores e as médias ajustadas das populações foram altos e significativos (Tabelas 43 e 44). Com a variância genética os coeficientes foram baixos e não significativos. Isto mostra que o potencial das populações foi definido, quase exclusivamente, pela média e que a variância genética desempenhou um papel secundário, pouco afetando a proporção de progênies superiores. Considerando apenas as 14 populações formadas pelo cruzamento entre linhagens adaptadas $(1,2,3,4$, e 5) com não adaptadas $(6,7$ e 8$)$, a média das populações também foi mais importante do que a variância genética para determinar o potencial das populações.

A maior importância da média na determinação do potencial de populações de soja para o melhoramento foram verificadas por Ininda et al.(1996), Vello et al. (1984), Schoener \& Fehr (1979) e Thome \& Fehr (1970), em populações com certa semelhança às utilizadas neste estudo. 
Tabela 43. Coeficientes de correlação de Pearson entre a proporção de progênies superiores e a média e a variância genética das populações.

\begin{tabular}{|c|c|c|c|c|c|c|c|c|c|c|c|c|}
\hline \multirow[b]{2}{*}{ Geração } & \multicolumn{2}{|c|}{$A M$} & \multicolumn{2}{|c|}{$P G$} & \multicolumn{2}{|c|}{$\overline{D M}$} & \multicolumn{2}{|c|}{ DF } & \multicolumn{2}{|c|}{$\overline{A F}$} & \multicolumn{2}{|c|}{$\overline{A C T}$} \\
\hline & $\overline{\bar{x}}$ & $\sigma_{g}{ }^{2}$ & $\bar{x}$ & $\sigma_{g}^{2}$ & $\bar{x}$ & $\sigma_{g}^{2}$ & $\bar{x}$ & $\sigma_{g}{ }^{2}$ & $\bar{x}$ & $\sigma_{\mathrm{g}}{ }^{2}$ & $\bar{x}$ & $\sigma_{g}^{2}$ \\
\hline$F_{2: 8}$ & $0,95^{\star \star}$ & 0,32 & $0,91^{\star \star}$ & $-0,1$ & & & & & & & $0,96^{\star \star}$ & 0,26 \\
\hline$F_{2: 9}$ & $0,93^{\star \star}$ & 0,30 & $0,94^{\star \star}$ & 0,00 & $0,74^{\star \star}$ & 0,00 & $0,98^{\star \star}$ & 0,53 & $0,94^{\star \star}$ & $0,52^{*}$ & 0,42 & 0,32 \\
\hline$F_{2: 10}$ & $0,94^{\star \star}$ & $-0,13$ & $0,95^{\star \star}$ & 0,04 & & & $0,91^{\star \star}$ & 0,32 & $0,89^{\star *}$ & 0,22 & & \\
\hline$F_{2: 11}$ & $0,94^{\star \star}$ & 0,53 & $0,96^{\star \star}$ & $-0,4$ & $0,88^{\star \star}$ & $-0,33$ & $0,97^{\star \star}$ & 0,06 & $0,93^{\star \star}$ & 0,17 & & \\
\hline Conjunta & $0,93^{\star \star}$ & 0,25 & $0,96^{\star \star}$ & 0,03 & $0,86^{\star \star}$ & $-0,09$ & $0,98^{\star \star}$ & 0,4 & $0,93^{\star \star}$ & 0,15 & $0,82^{\star \star}$ & 0,27 \\
\hline
\end{tabular}

AC - Acamamento; AF - Altura das plantas no florescimento; AM - altura das plantas na maturação; DF dias para o florescimento; DM - dias para a maturação; $P G$ - produção de grãos

Tabela 44. Coeficientes de correlação de Spearman entre a proporção de progênies superiores e a média e a variância genética das populações.

\begin{tabular}{|c|c|c|c|c|c|c|c|c|c|c|c|c|}
\hline \multirow[b]{2}{*}{ Geração } & \multicolumn{2}{|c|}{ AM } & \multicolumn{2}{|c|}{$P G$} & \multicolumn{2}{|c|}{$\overline{D M}$} & \multicolumn{2}{|c|}{$\overline{D F}$} & \multicolumn{2}{|c|}{$\mathrm{AF}$} & \multicolumn{2}{|c|}{ ACT } \\
\hline & $\bar{x}$ & $\sigma_{g}^{2}$ & $\bar{x}$ & $\sigma_{g}^{2}$ & $\bar{x}$ & $\sigma_{g}^{2}$ & $\bar{x}$ & $\sigma_{\mathrm{g}}{ }^{2}$ & $\bar{x}$ & $\sigma_{\mathrm{g}}{ }^{3}$ & $\overline{\bar{X}}$ & $\sigma_{g}{ }^{3}$ \\
\hline$F_{28}$ & $0,96^{\star \star}$ & 0,35 & $0,92^{\star \star}$ & $-0,19$ & & & & & & & $0,96^{\star \star}$ & 0,26 \\
\hline$F_{29}$ & $0,93^{*}$ & 0,39 & $0,93^{\star *}$ & 0,05 & $0,72^{\star *}$ & 0,14 & $0,93^{* \star}$ & $0,75^{\star \star}$ & $0,96^{\star \star}$ & $0,43^{\star}$ & $0,40^{*}$ & $0,40^{*}$ \\
\hline$F_{2: 10}$ & $0,96^{\star \star}$ & $-0,13$ & $0,94^{* *}$ & 0,04 & $0,89^{\star \star}$ & $-0,43^{*}$ & $0,81^{\star *}$ & 0,29 & $0,83^{\star \star}$ & 0,33 & & \\
\hline$F_{2: 11}$ & $0,98^{\star \star}$ & $0,53^{\star \star}$ & $0,96^{\star \star}$ & $-0,36$ & & & $0,96^{\star *}$ & 0,06 & $0,93^{\star *}$ & 0,16 & & \\
\hline Conjunta & $0,94^{\star \star}$ & 0,39 & $0,94^{\star *}$ & 0,01 & $0,87^{\star \star}$ & $-0,17$ & $0,92^{\star \star}$ & 0,31 & $0,88^{\star *}$ & 0,17 & $0,77^{\star *}$ & 0,29 \\
\hline
\end{tabular}

AC - Acamamento; AF - Altura das plantas no florescimento; AM - altura das plantas na maturação; DF dias para o florescimento; DM - dias para a maturação; PG - produção de grãos

O potencial de uma população para fins de melhoramento é determinado pela média e variância genética. Quando as médias apresentam valores semelhantes, a variância genética é o principal parâmetro que diferencia as populações (Cox et al., 1985). Porém, a medida que as médias vão se tornando diferentes, a variância vai perdendo importância até que o comportamento relativo das populações seja praticamente independente de seu valor (Thorne \& Fehr, 1970). É isto o que ocorreu com o conjunto de populações estudadas. As médias foram diferentes o suficiente para determinar o potencial das populações, independente da variância genética.

Pulcinelli (1997) realizou um procedimento muito semelhante para obter a proporção de progênies superiores para os caracteres produção de grãos e altura das 
plantas na maturação. O autor utilizou a média das populações enquanto este trabalho utilizou a média das progênies de todas as populações. As duas médias seriam iguais se todas as populações apresentassem o mesmo número de progênies, porém, a população $1 \times 4$ foi representada apenas por 13 progênies. Portanto, as diferenças encontradas na proporção de progênies superiores das populações nos caracteres produção de grãos e altura das plantas na maturação neste trabalho e no realizado por Pulcinelli (1997) foram devidas as diferenças entre os valores limites para que determinada progênie fosse considerada superior.

4.10 Predições a respeito do comportamento das 25 populações endogâmicas

4.10.1 Capacidade preditiva da média dos genitores

A análise dialélica das populações utilizadas neste estudo mostrou que a soma dos efeitos dominantes e epistáticos, medidos pela capacidade específica de combinação, foi pequena, sendo menor do que o resíduo experimental para a maioria dos caracteres. Desta maneira, podemos supor que a média das populações é formada principalmente por efeitos aditivos e que pode ser predita pela média dos genitores.

De fato, a média dos genitores apresentou alta correlação com a média das populações para todos os caracteres estudados. A única correlação não significativa foi verificada com o acamamento na geração $F_{2: 9}$. Em todas as demais análises realizadas os coeficientes de Pearson e Spearman (Tabela 45) foram significativos e altos.

As correlações também foram altas entre a média dos genitores e a proporção de progênies superiores (Tabela 45). A única exceção foi verificada para o caráter dias para maturação na geração $F_{2: 9}$, que apresentou coeficiente baixo e não significativo. Estes resultados mostram que a média dos genitores predisse com relativa segurança o potencial das populações. 
Tabela 45. Coeficientes de correlação de Pearson e Spearman entre a média dos genitores e a média das populações e com a proporção de progênies superiores.

\begin{tabular}{|c|c|c|c|c|c|c|c|c|c|c|c|c|}
\hline \multirow[b]{2}{*}{ Pearson } & \multicolumn{6}{|c|}{ Média ${ }_{\text {genitores }}$ VS. média ${ }_{\text {populacão }}$} & \multicolumn{6}{|c|}{ Média genitores Vs. Proporção } \\
\hline & $A C$ & AF & AM & DF & DM & $P G$ & $A C$ & AF & AM & DF & $\mathrm{DM}$ & $P G$ \\
\hline$\overline{F_{2: 8}}$ & $0,86^{\star \star}$ & & $0,90^{\star \star}$ & & & $0,61^{\star \star}$ & $0,85^{\star \star}$ & & $0,92^{\star \star}$ & & & $0,62^{\star}$ \\
\hline $2: 9$ & 0,34 & $0,75^{\star \star}$ & $0,93^{\star \star}$ & $0,96^{\star \star}$ & $0,47^{\star}$ & $0,85^{\star \star}$ & $0,75^{\star \star}$ & $0,70^{\star \star}$ & $0,93^{\star \star}$ & $0,95^{\star \star}$ & 0,27 & $0,81^{\star \star}$ \\
\hline $2: 10$ & & $0,84^{\star \star}$ & $0,92^{\star \star}$ & $0,89^{\star \star}$ & & $0,71^{\star \star}$ & & $0,71^{\star \star}$ & $0,90^{\star \star}$ & $0,90^{\star \star}$ & & $0,66^{\star}$ \\
\hline 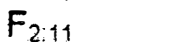 & & $0,89^{\star \star}$ & $0,91^{\star \star}$ & $0,87^{\star \star}$ & $0,76^{\star \star}$ & $0,84^{\star \star}$ & & $0,88^{\star \star}$ & $0,90^{\star \star}$ & $0,83^{\star *}$ & $0,61^{\star \star}$ & $0,82^{\star *}$ \\
\hline Conjunta & $0,68^{\star *}$ & $0,87^{\star \star}$ & $0,94^{\star *}$ & $0,94^{\star \star *}$ & $0,70^{\star \star}$ & $0,80 * *$ & $0,94^{* *}$ & $0,80^{* \star}$ & $0,94^{\star \star}$ & $0,94^{\star \star}$ & $0,58^{* *}$ & $0,75^{\star \star}$ \\
\hline Spearman & $A C$ & AF & AM & DF & DM & $P G$ & $A C$ & AF & AM & DF & DM & $P G$ \\
\hline$\overline{F_{2: 8}}$ & $0,85^{\star \star}$ & & $0,87^{\star \star}$ & & & $0,68^{\star \star}$ & $0,84^{\star \star}$ & & $0,89^{\star \star}$ & & & $0,69^{\star \star}$ \\
\hline$F_{2: 9}$ & 0,34 & $0,67^{\star \star}$ & $0,89^{\star \star}$ & $0,77^{\star \star}$ & $0,52^{\star \star}$ & $0,85^{\star \star}$ & $0,75^{\star \star}$ & $0,62^{\star \star}$ & $0,88^{\star \star}$ & $0,75^{\star \star}$ & 0,25 & $0,81^{\star *}$ \\
\hline $2: 10$ & & $0,82^{\star \star}$ & $0,84^{\star \star}$ & $0,77^{\star \star}$ & & $0,71^{\star \star}$ & & $0,63^{\star \star}$ & $0,82^{\star \star}$ & $0,59^{\star \star}$ & & $0,65^{\star \star}$ \\
\hline $2: 11$ & & $0,85^{\star \star}$ & $0,87^{\star \star}$ & $0,77^{\star \star}$ & $0,84^{\star \star}$ & $0,84^{\star \star}$ & & $0,83^{\star *}$ & $0,85^{\star \star}$ & $0,74^{\star \star}$ & $0,69^{\star \star}$ & $0,85^{\star \star}$ \\
\hline Conju & $0,64^{\star \star}$ & $0,83^{\star \star}$ & $0,88^{\star \star}$ & $0,82^{\star \star}$ & $0,71^{\star \star}$ & $0,82^{\star \star}$ & $0,81^{\star \star}$ & $0,72^{\star \star}$ & $0,92^{\star \star}$ & $0,74^{\star \star}$ & $0,71^{\star \star}$ & $0,77^{\star \star}$ \\
\hline
\end{tabular}

Se fosse desejado obter apenas as cinco populações com maior média no caráter produção de grãos, a média dos genitores selecionaria as populações $2 \times 3,2 \times 4$, $2 \times 5,3 \times 5$ e $4 \times 5$. Entre as populações selecionadas, quatro pertencem ao grupo das populações mais produtivas e uma $(2 \times 5)$ pertence ao segundo melhor grupo, segundo a técnica Scott \& Knott (Tabela 27). A comparação do desempenho das populações selecionadas com o desempenho médio de todas as 25 populações mostrou que as selecionadas foram muito superiores com relação à produção de grãos e ao acamamento (Tabela 46). Para os demais caracteres as diferenças foram pequenas.

Tabela 46. Proporção de progênies superiores das populações selecionadas para produção de grãos pela média dos genitores e a proporção de progênies superiores média de todas as 25 populações.

\begin{tabular}{ccccccc}
\hline & AM & $P G$ & DM & AF & DF & AC \\
\hline $2 \times 3$ & 0,55 & 0,85 & 0,75 & 0,55 & 0,40 & 0,10 \\
$2 \times 4$ & 0,70 & 0,80 & 0,85 & 0,30 & 0,15 & 0,20 \\
$2 \times 5$ & 0,70 & 0,60 & 0,65 & 0,30 & 0,20 & 0,25 \\
$3 \times 5$ & 0,05 & 0,85 & 0,55 & 0,15 & 0,05 & 0,00 \\
$4 \times 5$ & 0,05 & 1,00 & 0,65 & 0,25 & 0,25 & 0,20 \\
\hline Média & 0,41 & 0,82 & 0,69 & 0,31 & 0,21 & 0,15 \\
Média (25) & 0,47 & 0,50 & 0,53 & 0,43 & 0,40 & 0,44 \\
\hline
\end{tabular}

AC - Acamamento; AF - Altura das plantas no florescimento; $A M$ - altura das plantas na maturação; DF - dias para o florescimento; DM - dias para a maturação; PG - produção de grãos 
Estes resultados permitem inferir que o conhecimento das médias dos genitores seria suficiente para identificar as populações mais promissoras, considerando este conjunto fixo de populações. Caso o objetivo fosse maximizar a média, como para produção de grãos, os genitores escolhidos devem ser aqueles com maiores médias. Se o objetivo for minimizar a média, como para acamamento, os genitores escolhidos devem ser aqueles com menores médias.

4.10.2 Capacidade preditiva do dialelo realizado na geração $F_{2}$

As estimativas das capacidades gerais de combinação obtidas em $F_{2}$ apresentaram correlações altas com a capacidade geral de combinação das populações endogâmicas (Tabela 47). Este resultado indica que o componente aditivo das médias das populações pode ser predito com boa confiabilidade. Portanto, não seria necessário avançar as populações até a obtenção de niveis altos de endogamia para estimar o componente aditivo das médias.

A capacidade especifica das populações endogâmicas não pode ser predita pela análise realizada em $F_{2}$, sendo a correlação significativa apenas para o caráter produção de grãos em $F_{2: 8}$ e na análise conjunta (Tabela 47). O baixo nível de heterozigose esperado após oito ciclos de autofecundações sucessivas (aproximadamente $0,78 \%$ ) fez com que os efeitos de dominância não estivessem presentes nas populações endogâmicas. Nas populações $F_{2} \circ$ nivel de heterozigose é elevado ( $50 \%$ dos locos contrastantes nos genitores) e os efeitos de dominância deviam estar presentes. De fato, a análise destas mesmas populações $F_{2}$ realizada, por Pimentel (1991), evidenciou a presença de heterose com ampla variação entre as populações. Adicionalmente, a capacidade especifica das populações $F_{2: n}$ é composta por efeitos epistáticos, somente formados após a obtenção da homozigose (Stuthman \& Stucker, 1975; Choo et al., 1986). Portanto, a capacidade especifica estimada em $F_{2}$ e $F_{2: n}$ não são formadas pelos mesmos efeitos genéticos e, em conseqüência, não apresentaram correlações.

Cabe destacar que as correlações entre as capacidades geral e especifica de combinação estimadas em $F_{2}$ e $F_{2: n}$ já haviam sido realizados por Pulcinelli (1997) para os caracteres produção de grãos e altura das plantas na maturação. 
A soma dos efeitos da capacidade geral de combinação $\left(g_{i}+g_{j}\right)$ apresentou altas correlações com a média das populações e com a proporção de progênies superiores. As magnitudes dos coeficientes de correlação de Pearson e Spearman (Tabela 48) foram semelhantes às obtidas com a média dos genitores.

Tabela 47. Coeficientes de correlação de Pearson e Spearman entre as capacidades gerais e específicas estimadas no dialelo em $F_{2}$ e em $F_{2: n}$.

\begin{tabular}{|c|c|c|c|c|c|c|c|c|c|c|c|c|}
\hline \multirow[b]{2}{*}{ Pearson } & \multicolumn{6}{|c|}{$\mathrm{CGC}_{\mathrm{F} 2}$ vs. $\mathrm{CGC}_{\mathrm{F} 2: \mathrm{n}}$} & \multicolumn{6}{|c|}{$\mathrm{CEC}_{\mathrm{F} 2}$ vs. $\mathrm{CEC}_{\mathrm{F} 2: n}$} \\
\hline & AM & PG & $\mathrm{DM}$ & $A F$ & DF & $A C$ & $\overline{A M}$ & $P G$ & DM & $\mathrm{AF}$ & DF & $A C$ \\
\hline$\overline{F_{2: 8}}$ & $0,90^{\star \star}$ & $0,90^{\star \star}$ & & & & $0,91^{\star \star}$ & 0,28 & $0,64^{\star \star}$ & & & & $-0,11$ \\
\hline$F_{2: 9}$ & $0,93^{\star \star}$ & $0,87^{\star \star}$ & $0,68^{* *}$ & $0,77^{\star \star}$ & $0,96^{\star \star}$ & $0,66^{\star \star}$ & 0,18 & 0,29 & 0,40 & 0,06 & $-0,06$ & $-0,23$ \\
\hline$F_{2: 10}$ & $0,91^{\star \star}$ & $0,76^{\star \star}$ & & $0,78^{\star \star}$ & $0,92^{\star \star}$ & & 0,23 & 0,17 & & $-0,15$ & 0,18 & \\
\hline$F_{2: 11}$ & $0,89^{\star *}$ & $0,91^{\star \star}$ & $0,85^{\star \star}$ & $0,76^{\star \star}$ & $0,92^{\star \star}$ & & 0,01 & 0,32 & 0,04 & $-0,22$ & $-0,04$ & \\
\hline Conjunta & $0,92^{\star \star}$ & $0,91^{\star \star}$ & $0,88^{\star \star}$ & $0,80^{\star \star}$ & $0,95^{\star \star}$ & $0,88^{\star \star}$ & 0,20 & $0,44^{\star}$ & 0,27 & $-0,11$ & 0,07 & $-0,22$ \\
\hline$\overline{\text { Spearman: }}$ & AM & $\overline{P G}$ & $\overline{D M}$ & $\overline{A F}$ & $\overline{D F}$ & $\overline{A C}$ & $A M$ & $\overline{P G}$ & $\overline{D M}$ & $\overline{A F}$ & DF & $A C$ \\
\hline$\overline{F_{2.8}}$ & 0,59 & $0,90^{\star \star}$ & & & & $0,83^{\star \star}$ & 0,20 & $0,58^{\star}$ & & & & 0,33 \\
\hline$F_{2: 9}$ & 0,57 & $0,93^{\star \star}$ & 0,31 & 0,07 & $0,76^{\star}$ & $0,74^{*}$ & 0,09 & 0,19 & 0,43 & 0,00 & 0,00 & 0,12 \\
\hline$F_{2: 10}$ & 0,54 & $0,79^{*}$ & $0,88^{\star \star}$ & 0,26 & 0,48 & & 0,22 & 0,12 & & $-0,10$ & 0,14 & \\
\hline & 0,56 & $0,93^{\star \star}$ & & 0,19 & $0,72^{\star}$ & & 0,06 & 0,32 & 0,02 & $-0,09$ & $-0,07$ & \\
\hline Conjunta & 0,61 & $0,93^{\star \star}$ & 0,60 & 0,24 & $0,76^{\star}$ & $0,78^{*}$ & 0,12 & 0,40 & 0,30 & $-0,13$ & 0,05 & 0,31 \\
\hline
\end{tabular}

AC - Acamamento; AF - Altura das plantas no florescimento; AM - altura das plantas na maturação; DF dias para oflorescimento; DM - dias para a maturação; PG - produção de grãos

Tabela 48. Coeficientes de correlação de Pearson e Spearman entre a soma das capacidades gerais de combinação $\left(g_{i}+g_{j}\right)$ estimadas em $F_{2}$ com a média ajustada das populações e com a proporção de progênies superiores.

\begin{tabular}{|c|c|c|c|c|c|c|c|c|c|c|c|c|}
\hline \multirow[b]{2}{*}{ Pearson } & \multicolumn{6}{|c|}{$\mathrm{CGC}_{\mathrm{F} 2}$ vs. média } & \multicolumn{6}{|c|}{$\mathrm{CGC}_{\mathrm{F} 2}$ vs. proporção } \\
\hline & $A M$ & PG & DM & $\mathrm{AF}$ & $\mathrm{DF}$ & $A C$ & $A M$ & $P G$ & $\overline{D M}$ & $\mathrm{AF}$ & DF & $A C$ \\
\hline $2: 8$ & $0,85^{\star \star}$ & $0,80^{\star \star}$ & & & & 0,28 & $0,86^{\star \star}$ & $0,81^{\star \star}$ & & & & 0,31 \\
\hline $2: 9$ & $0,89^{\star \star}$ & $0,78^{\star \star}$ & $0,55^{\star \star}$ & $0,76^{\star \star}$ & $0,95^{\star \star}$ & 0,20 & $0,88^{\star \star}$ & $0,84^{\star \star}$ & 0,36 & $0,77^{\star \star}$ & $0,95^{\star \star}$ & $0,40^{\star}$ \\
\hline $2: 10$ & $0,86^{\star \star}$ & $0,67^{\star \star}$ & & $0,73^{\star \star}$ & $0,86^{\star \star}$ & & $0,87^{\star \star}$ & $0,62^{\star \star}$ & & $0,77^{\star \star}$ & $0,84^{\star \star}$ & \\
\hline 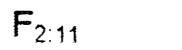 & $0,83^{\star \star}$ & $0,88^{\star *}$ & $0,73^{\star \star}$ & $0,77^{\star \star}$ & $0,86^{\star \star}$ & & $0,82^{\star \star}$ & $0,81^{\star \star}$ & $0,58^{\star \star}$ & $0,76^{\star \star}$ & $0,85^{\star \star}$ & \\
\hline Conj & $0,88^{\star *}$ & $0,85^{\star \star}$ & $0,73^{\star \star}$ & $0,80^{\star \star}$ & $0,92^{\star \star}$ & 0,27 & $0,87^{\star \star}$ & $0,86^{\star \star}$ & $0,59^{\star *}$ & $0,83^{\star \star}$ & $0,91^{\star *}$ & 0,36 \\
\hline Spea & $A M$ & $P G$ & DM & $\mathrm{AF}$ & $\mathrm{DF}$ & $A C$ & $A M$ & $P G$ & $\overline{D M}$ & $\overline{A F}$ & DF & $\overline{A C}$ \\
\hline $2: 8$ & $0,71^{\star \star}$ & $0,85^{\star \star}$ & & & & 0,13 & $0,75^{\star \star}$ & $0,80^{\star \star}$ & & & & 0,19 \\
\hline 2.9 & $0,79^{\star \star}$ & $0,81^{\star *}$ & 0,54 & $0,55^{\star \star}$ & $0,78^{\star *}$ & 0,03 & $0,78^{\star \star}$ & $0,84^{\star \star}$ & 0,33 & $0,58^{\star \star}$ & $0,80^{\star \star}$ & 0,35 \\
\hline $2: 10$ & $0,74^{\star \star}$ & $0,74^{\star \star}$ & & $0,57^{\star \star}$ &, $074^{\star \star}$ & & $0,77^{\star \star}$ & $0,64^{\star \star}$ & & $0,54^{\star \star}$ & $0,49^{\star}$ & \\
\hline & $0,70^{\star \star}$ & $0,90^{\star \star}$ &, $177^{*}$ & $0,67^{\star \star}$ & $0,79^{\star \star}$ & & $0,69^{\star \star}$ & $0,90^{\star \star}$ & $0,61^{\star \star}$ & $0,64^{\star \star}$ & $0,77^{\star \star}$ & \\
\hline Conjunta & $0,73^{\star \star}$ & $0,86^{\star \star}$ & $0,70^{\star \star}$ & $0,59^{*}$ & $0,82^{\star \star}$ & 0,04 & $0,75^{\star \star}$ & $0,87^{\star \star}$ & $0,67^{\star \star}$ & $0,53^{\star \star}$ & $0,71^{\star \star}$ & 0,26 \\
\hline
\end{tabular}

AC - Acamamento; AF - Altura das plantas no florescimento; AM - altura das plantas na maturação; DF dias para o florescimento; DM - dias para a maturação; PG - produção de grãos 
A variância genética e a proporção de progênies superiores se comportaram de modo independente da capacidade específica de combinação (Tabela 49). Portanto, a capacidade especifica estimada $F_{2}$ tem pouca utilidade se 0 melhoramento será realizado utilizando populações endogâmicas.

Tabela 49. Coeficientes de correlação de Pearson e Spearman entre a capacidade específica de combinação estimadas em $\mathrm{F}_{2}$ com a variância genética das populações e com a proporção de progênies superiores.

\begin{tabular}{|c|c|c|c|c|c|c|c|c|c|c|c|c|}
\hline \multirow[b]{2}{*}{ Pearson } & \multicolumn{6}{|c|}{$\mathrm{CEC}_{\mathrm{F} 2}$ vs. variância } & \multicolumn{6}{|c|}{$\mathrm{CEC}_{\mathrm{F} 2}$ vs. proporção } \\
\hline & $A M$ & $P G$ & $\mathrm{DM}$ & $\overline{A F}$ & $\overline{D F}$ & $A C$ & AM & $P G$ & $\overline{D M}$ & AF & DF & $A C$ \\
\hline$\overline{F_{2: 8}}$ & 0,27 & $-0,22$ & & & & $-0,02$ & 0,24 & 0,21 & & & & 0,07 \\
\hline$F_{2: 9}$ & 0,10 & 0,01 & 0,16 & 0,02 & 0,04 & 0,09 & 0,31 & 0,05 & 0,07 & $-0,12$ & $-0,04$ & 0,22 \\
\hline$F_{2: 10}$ & 0,06 & 0,05 & & 0,03 & 0,16 & & 0,28 & 0,06 & & $-0,05$ & 0,08 & \\
\hline$F_{2: 11}$ & 0,19 & $-0,42^{*}$ & $-0,19$ & $-0,31$ & 0,25 & & 0,20 & 0,15 & $-0,13$ & 0,00 & $-0,07$ & \\
\hline Conjunta & 0,26 & $-0,07$ & $-0,29$ & $-0,25$ & 0,22 & 0,06 & 0,23 & 0,14 & 0,01 & 0,01 & 0,04 & 0,15 \\
\hline Spearman & $\overline{A M}$ & $\overline{P G}$ & $\overline{D M}$ & $\overline{A F}$ & $\overline{D F}$ & $\overline{A C}$ & $\overline{A M}$ & PG & $\overline{\mathrm{DM}}$ & $\overline{A F}$ & DF & $\overline{A C}$ \\
\hline$\overline{F_{2: 8}}$ & 0,26 & $-0,05$ & & & & 0,20 & 0,19 & 0,24 & & & & 0,09 \\
\hline $\mathrm{F}_{2: 9}$ & 0,14 & $-0,01$ & 0,15 & 0,04 & $-0,03$ & 0,05 & 0,28 & 0,08 & 0,02 & $-0,10$ & 0,08 & 0,00 \\
\hline$F_{2: 10}$ & 0,14 & 0,06 & & 0,00 & 0,18 & & 0,21 & 0,11 & & $-0,09$ & 0,26 & \\
\hline$F_{2: 11}$ & 0,17 & $-0,35$ & $-0,11$ & $-0,22$ & 0,19 & & 0,18 & 0,18 & $-0,19$ & $-0,02$ & 0,06 & \\
\hline Conjunta & 0,24 & 0,01 & $-0,28$ & $-0,25$ & 0,14 & 0,04 & 0,20 & 0,19 & 0,01 & $-0,04$ & 0,19 & 0,07 \\
\hline
\end{tabular}

Caso cinco populações fossem selecionadas com base nas estimativas da capacidade geral de combinação do caráter produção de grãos obtidas em $F_{2}$, seriam eleitas as populações $2 \times 3,2 \times 4,3 \times 5,4 \times 5$ e $4 \times 8$.

Essas populações pertencem ao grupo das mais produtivas, segundo a análise de agrupamento de Scott \& Knott. Verifica-se na Tabela 50 que a seleção para a produção de grãos foi mais efetiva do que a realizada pela média dos genitores.

A maior efetividade da seleção realizada coincide com a maior correlação com a proporção de progênies mais produtivas. Portanto, a capacidade geral de combinação estimada em $\mathrm{F}_{2}$ realizaria predições um pouco mais confiáveis a respeito do comportamento das populações endogâmicas quanto à produção de grãos do que as realizadas pela média dos genitores. Para os demais caracteres, as predições realizadas teriam o mesmo nível de confiabilidade da média dos genitores. 
A principal desvantagem deste método é que ele necessita que todas as populações sejam formadas e que experimentos sejam realizados em $F_{2}$ para que os parâmetros sejam estimados. Como é mais fácil realizar experimentos para avaliar os genitores, pode ser questionável se a confiabilidade um pouco maior verificada apenas para a produção de grãos é suficiente para que este método seja utilizado em detrimento da média dos genitores.

O conjunto de populações utilizadas neste estudo é fixo, portanto as conclusões somente são válidas para este mesmo conjunto. Mas, se outro conjunto com características bastante a este precisar ser formado, é bastante provável que este método possa auxiliar o melhorista a tomar decisões, conforme já havia concluido Pulcinelli (1997).

Tabela 50. Proporção de progênies superiores das populações selecionadas para produção de grãos pela capacidade geral de combinação estimada em $F_{2}$ e a proporção de progênies superiores média das 25 populações.

\begin{tabular}{ccccccc}
\hline & AM & $P G$ & DM & AF & DF & AC \\
\hline $2 \times 3$ & 0,55 & 0,85 & 0,75 & 0,55 & 0,40 & 0,10 \\
$2 \times 4$ & 0,70 & 0,80 & 0,85 & 0,30 & 0,15 & 0,20 \\
$3 \times 5$ & 0,05 & 0,85 & 0,55 & 0,15 & 0,05 & 0,00 \\
$4 \times 5$ & 0,05 & 1,00 & 0,65 & 0,25 & 0,25 & 0,20 \\
$4 \times 8$ & 0,90 & 0,95 & 0,60 & 0,95 & 1,00 & 0,80 \\
\hline Média & 0,45 & 0,89 & 0,68 & 0,44 & 0,37 & 0,26 \\
Média (25) & 0,47 & 0,50 & 0,53 & 0,43 & 0,40 & 0,44 \\
\hline
\end{tabular}

$A C$ - Acamamento; AF - Altura das plantas no florescimento; $A M$ - altura das plantas na maturação; DF - dias para o florescimento; DM - dias para a maturação; PG - produção de grãos

\subsubsection{Capacidade preditiva da distância euclidiana}

A distância euclidiana não foi um bom preditor da variância genética das populações (Tabela 51), apresentando correlações baixas e não significativas com a maioria dos caracteres. Os melhores desempenhos foram verificados para altura das plantas no florescimento e dias para florescimento. Embora a distância euclidiana tenha apresentado correlações significativas com estes caracteres, os valores dos coeficientes foram relativamente baixos e erráticos, o que não permitiria sua utilização para selecionar populações com maior variabilidade. 
Com as médias ajustadas das populações, a distância euclidiana apresentou correlações significativas com os caracteres acamamento, altura das plantas na maturação, dias para o florescimento e produção de grãos (Tabela 52). Os valores dos coeficientes de correlação não foram muito altos, indicando que predições da média das populações feitas a partir da distância euclidiana não seriam muito confiáveis. Para os demais caracteres, as correlações foram não significativas.

As correlações entre a distância euclidiana e a proporção de progênies superiores das populações foram semelhantes às obtidas com as médias ajustadas (Tabela 53). As maiores diferenças foram verificadas no caráter altura das plantas no florescimento, cujos coeficientes foram maiores com a proporção de progênies superiores do que com a média das populações.

O único caráter que as médias das populações foram negativamente correlacionas com a distância euclidiana foi produção de grãos. O comportamento observado das linhagens na maioria dos caracteres foi bastante alterado em produção de grãos e isto pode ter ocasionado a correlação negativa.

Tabela 51. Coeficientes de correlação de Pearson (P) e Sperman (S) entre a distância euclidiana e a variância genética das populações.

\begin{tabular}{|c|c|c|c|c|c|c|c|c|c|c|c|c|}
\hline \multirow[b]{2}{*}{ Geração } & \multicolumn{2}{|c|}{$A C$} & \multicolumn{2}{|c|}{ AF } & \multicolumn{2}{|c|}{$A M$} & \multicolumn{2}{|c|}{$\overline{D F}$} & \multicolumn{2}{|c|}{$D M$} & \multicolumn{2}{|c|}{$P G$} \\
\hline & $P$ & $S$ & $P$ & $S$ & $P$ & $S$ & $P$ & $S$ & $P$ & $S$ & $P$ & $S$ \\
\hline $\mathrm{F}_{2: 8}$ & 0,17 & 0,08 & & & $-0,23$ & $-0,13$ & & & & & $-0,31$ & $-0,41^{\star}$ \\
\hline$F_{2: 9}$ & 0,28 & 0,30 & $0,58^{\star \star}$ & $0,75^{\star \star}$ & 0,25 & 0,28 & 0,29 & 0,33 & $-0,14$ & $-0,25$ & $-0,31$ & $-0,31$ \\
\hline$F_{2: 10}$ & & & 0,28 & 0,32 & 0,08 & 0,09 & $0,44^{\star}$ & 0,20 & & $-0,23$ & $-0,07$ & $-0,10$ \\
\hline$F_{2: 11}$ & & & $0,45^{\star}$ & $0,48^{\star}$ & 0,09 & 0,07 & 0,13 & 0,00 & $-0,15$ & & $-0,08$ & $-0,16$ \\
\hline Conjunta & 0,33 & 0,23 & 0,34 & 0,33 & 0,04 & 0,18 & $0,51^{\star \star}$ & 0,30 & 0,32 & 0,21 & $-0,29$ & $-0,36$ \\
\hline
\end{tabular}

Tabela 52. Coeficientes de correlação de Pearson $(P)$ e Spearman $(S)$ entre a distância euclidiana e a média das populações.

\begin{tabular}{|c|c|c|c|c|c|c|c|c|c|c|c|c|}
\hline \multirow[b]{2}{*}{ Geração } & \multicolumn{2}{|c|}{$A C$} & \multicolumn{2}{|c|}{$\overline{A F}$} & \multicolumn{2}{|c|}{$\overline{A M}$} & \multicolumn{2}{|c|}{$\mathrm{DF}$} & \multicolumn{2}{|c|}{$\overline{D M}$} & \multicolumn{2}{|c|}{$P G$} \\
\hline & $P$ & S & $P$ & $S$ & $P$ & $S$ & $P$ & $S$ & $P$ & $S$ & $P$ & $S$ \\
\hline$F_{28}$ & $0,77^{\star \star}$ & $0,80^{\star \star *}$ & & & $0,44^{\star}$ & 0,51 & & & & & $-0,29$ & 0,17 \\
\hline$=2.5$ & $0,46^{*}$ & 0,41 & $0,48^{\star}$ & $0,46^{\star}$ & 0,5 & $0,66^{\star \star}$ & $0,65^{\star \star}$ & $0,65^{\star}$ & $-0,44^{*}$ & $-0,31$ & $3^{\star \star}$ & *. \\
\hline$=$ & & & 0,30 & 0 & 0 & $0,55^{\star \star}$ & $0,55^{\star \star}$ & $0,53^{\star}$ & & 0,05 & :-0 & $x^{*}-1$ \\
\hline & & & 0,27 & 0 & 0 & 0,37 & 0,5 & $0,62^{\star x}$ & & & $\vdots-0$ & $11^{\star \star}$ \\
\hline & $0,69^{\star}$ & $0,70^{\star \star}$ & 0,38 & 0,34 & $0,44^{*}$ & $0,59^{\star \star}$ & $0,62^{\star \star}$ & $0,58^{\star}$ & $-0,29$ & $-0,19$ & $-0,55^{\star \star}$ & ${ }^{\star}-0,47^{\star}$ \\
\hline
\end{tabular}

AC - Acamamento; AF - Altura das plantas no florescimento; AM - altura das plantas na maturação; $D F$ dias para o florescimento; DM - dias para a maturação; PG - produção de grãos 
Tabela 53. Coeficientes de correlação de Pearson (P) e Spearman (S) entre a distância euclidiana e a proporção de progênies superiores das populações.

\begin{tabular}{|c|c|c|c|c|c|c|c|c|c|c|c|c|}
\hline & \multicolumn{2}{|c|}{$A C$} & \multicolumn{2}{|c|}{$\mathrm{AF}$} & \multicolumn{2}{|c|}{ AM } & \multicolumn{2}{|c|}{ DF } & \multicolumn{2}{|c|}{ DM } & \multicolumn{2}{|c|}{$P G$} \\
\hline & $P$ & $S$ & $P$ & $S$ & $P$ & $S$ & $P$ & $S$ & $P$ & $S$ & $\mathrm{P}$ & S \\
\hline$\overline{F_{2: 8}}$ & $0,71^{\star \star}$ & $0,76^{\star *}$ & & & $0,49^{\star}$ & $0,53^{\star \star}$ & & & & & $-0,23$ & $-0,14$ \\
\hline$F_{2: 9}$ & $0,72^{\star \star}$ & $0,75^{\star \star}$ & $0,43^{\star}$ & $0,47^{*}$ & $0,62^{\star \star}$ & $0,74^{\star \star}$ & $0,67^{\star \star}$ & $0,61^{\star \star}$ & $-0,39$ & $-0,28$ & $-0,60^{* \star}$ & $-0,53^{\star \star}$ \\
\hline$F_{2: 10}$ & & & $0,57^{\star \star}$ & $0,59^{\star \star}$ & $0,58^{\star \star}$ & $0,64^{\star k}$ & $0,71^{\star \star}$ & $0,75^{\star \star}$ & & 0,08 & $-0,48^{\star}$ & $-0,41^{\star}$ \\
\hline$F_{2: 11}$ & & & 0,30 & 0,31 & 0,29 & 0,37 & $0,61^{\star \star}$ & $0,62^{\star \star}$ & $-0,11$ & & $-0,54^{\star \star}$ & $-0,47^{*}$ \\
\hline Conjunta & $0,76^{\star \star}$ & $0,77^{\star \star}$ & $0,56^{\star \star}$ & $0,51^{\star \star}$ & $0,52^{\star \star}$ & $0,59^{\star \star}$ & $0,65^{\star \star}$ & $0,61^{\star \star}$ & $-0,20$ & $-0,07$ & $-0,45^{\star}$ & $-0,31$ \\
\hline
\end{tabular}

Caso a distância euclidiana fosse utilizada para selecionar as populações mais promissoras utilizando o raciocínio de que quanto maior a distância maior a variância genética e melhores devem ser as populações, seriam selecionadas: $1 \times 8,3 \times 8,4 \times 8$, $5 \times 8$ e $6 \times 8$.

Apenas as populações $3 \times 8$ e $4 \times 8$ pertencem ao grupo das populações mais produtivas segundo o agrupamento realizado pelo método Scott \& Knott. As populações 1x8 e 5x8 pertencem ao grupo com produção intermediário e a $6 \times 8$ está entre as populações com pior desempenho. Portanto, esta seleção não seria efetiva. Este resultado já era esperado, pois a distância genética não estava correlacionada com a variância genética. Mesmo que estivesse, pouco resolveria, pois a variância genética não foi um fator importante na determinação do potencial destas populações.

A distância euclidiana utilizada neste estudo foi obtida pela análise do comportamento fenotípico das linhagens genitoras. Portanto, a média dos genitores poderia ser utilizada para verificar que a variância genética deve apresentar papel secundário na determinação do potencial das populações. As correlações entre a média dos genitores e a distância euclidiana foram negativas para a produção de grãos $(-0,78)$, positivas com a altura das plantas na maturação $(r=0,48)$, dias para florescimento $(r=0,60)$ e acamamento $(r=0,54)$ e nulas para os demais caracteres. Os sentidos destas correlações são os mesmos verificados entre a distância euclidiana e a média das populações.

Considerando estas informações, seria possivel tentar maximizar a média da produção de grãos das populações, selecionando aquelas que apresentassem menor 
distância euclidiana. Neste caso, as populações selecionadas seriam: 1x3, 1x4, 2x5, $3 \times 5$ e $4 \times 5$.

Observando a Tabela 27, percebemos que as populações $1 \times 3,1 \times 4,3 \times 5$ e 4x5 pertencem ao grupo das populações mais produtivas e que a $2 \times 5$ pertence ao grupo de produção intermediária. Logo, como se verifica na Tabela 54, a distância euclidiana foi capaz de realizar uma seleção efetiva para a produção de grãos.

A eficiência das seleções realizadas para maximizar a média da produção de grãos das populações pela média dos genitores e pela distância euclidiana foram semelhantes, o que năo indica que as capacidades preditivas de ambas tenham sido iguais. Se for considerado que quanto maior o coeficiente de correlação com a proporção de progênies superiores maior é a capacidade de predição da técnica, podemos concluir que as predições realizadas a partir da média dos genitores e da capacidade geral de combinação estimada em $F_{2}$ foram muito mais confiáveis do que as realizadas pela distância euclidiana.

Caso se deseje utilizar a distância euclidiana para realizar seleções entre populações com características semelhantes às utilizadas neste estudo, elas devem ser mais brandas do que as baseadas na capacidade geral de combinação estimada em $F_{2}$ e na média dos genitores. Deve-se também verificar se a distância euclidiana apresenta correlações significativas com a média dos genitores, que deve ser um bom indicativo da presença de correlações com a média das populações. Em caracteres onde a média dos genitores é independente da distância euclidiana a seleção não deve ser realizada, pois não será efetiva.

Tabela 54. Proporção de progênies superiores das populações selecionadas pela distância euclidiana visando maximizar a produção de grãos nas populações e a proporção média de todas as 25 populações estudadas.

\begin{tabular}{ccccccc}
\hline & AM & PG & DM & AF & DF & AC \\
\hline $1 \times 3$ & 0,10 & 0,90 & 0,90 & 0,55 & 0,30 & 0,15 \\
$1 \times 4$ & 0,00 & 0,69 & 0,38 & 0,00 & 0,00 & 0,08 \\
$2 \times 5$ & 0,70 & 0,60 & 0,65 & 0,30 & 0,20 & 0,25 \\
$3 \times 5$ & 0,05 & 0,85 & 0,55 & 0,15 & 0,05 & 0,00 \\
$4 \times 5$ & 0,05 & 1,00 & 0,65 & 0,25 & 0,25 & 0,20 \\
\hline Média & 0,18 & 0,81 & 0,63 & 0,25 & 0,16 & 0,14 \\
Média (25) & 0,47 & 0,50 & 0,53 & 0,43 & 0,40 & 0,44 \\
\hline
\end{tabular}

AC - Acamamento; AF - Altura das plantas no florescimento; $A M$ - altura das plantas na maturação; DF - dias para o florescimento; DM - dias para a maturação; $P G$ - produção de grãos 
4.10.4 Capacidade preditiva da distância euclidiana geral e especifica

A soma das distâncias euclidianas gerais $\left(D E G_{i}+D E G_{j}\right)$ apresentou correlações com a média das populações e com a proporção de progênies superiores em cinco caracteres. De modo geral, os coeficientes de correlação com a proporção de progênies superiores e a média das populações foram semelhantes (Tabela 55). A variância genética e a proporção de progênies superiores foram independentes da distância euclidiana geral (Tabela 56).

Os coeficientes de correlação obtidos pela distância euclidiana geral foram semelhantes aos obtidos com a distância euclidiana para a maioria dos caracteres. A única alteração que pode refletir na capacidade preditiva foi verificada no caráter dias para florescimento, que passou de 0,65 para 0,72 após a partição. As semelhanças entre as correlações com as duas distâncias já eram esperadas, pois quase toda a diversidade medida pela distância euclidiana está contida na distância euclidiana geral.

Se fosse realizada uma seleção com base na distância euclidiana especifica visando maximizar a variância genética das populações, ela seria inefetiva. Isto porque a variância não está correlacionada com a proporção de progênies superiores e a distância euclidiana específica não está correlacionada com a variância genética.

Tabela 55. Coeficientes de correlação de Pearson e Spearman entre a distância euclidiana geral e a média das populações e com a proporção de progênies superiores.

\begin{tabular}{|c|c|c|c|c|c|c|c|c|c|c|c|c|}
\hline \multirow[b]{2}{*}{ Pearson } & \multicolumn{6}{|c|}{ DEG vs. média } & \multicolumn{6}{|c|}{ DEG vs. proporção } \\
\hline & $\overline{A M}$ & $P G$ & DM & $\overline{A F}$ & $\overline{D F}$ & $A C$ & $\overline{A M}$ & $P G$ & $\overline{\mathrm{DM}}$ & AF & $\overline{D F}$ & $\overline{A C}$ \\
\hline$=2.8$ & $0,48^{\star}$ & $-0,31$ & & & & $0,81^{\star \star}$ & $0,48^{*}$ & $-0,31$ & & & & $0,74^{\star \star}$ \\
\hline 29 & $0,58^{\star \star}$ & $-0,71^{\star \star}$ & $-0,44^{\star}$ & $0,52^{\star \star}$ & $0,70^{\star \star}$ & $0,54^{\star \star}$ & $0,55^{\star \star}$ & $-0,64^{\star \star}$ & $-0,36$ & $0,51^{*}$ & $0,72^{\star \star}$ & $0,76^{\star \star}$ \\
\hline $2 \cdot 10$ & $0,46^{*}$ & $-0,55^{\star \star}$ & & 0,38 & $0,67^{\star \star}$ & & $0,55^{\star \star}$ & $-0,49^{\star}$ & & $0,57^{\star \star}$ & $0,78^{\star *}$ & \\
\hline $2: 11$ & 0,30 & $-0,61^{\star \star}$ & 0,02 & 0,31 & $0,63^{\star}$ & & 0,27 & $-0,54^{\star \star}$ & $-0,06$ & 0,38 & $0,66^{\star \star}$ & \\
\hline Conj. & $0,48^{\star}$ & $-0,57^{\star \star}$ & $-0,26$ & $0,44^{\star}$ & $0,70^{\star \star}$ & $0,76^{\star \star}$ & $0,48^{\star}$ & $-0,48^{\star}$ & $-0,11$ & $0,60^{* *}$ & $0,72^{\star \star}$ & $0,78^{\star *}$ \\
\hline pea & $\overline{A M}$ & $\overline{P G}$ & $\overline{D M}$ & $\overline{A F}$ & $\overline{D F}$ & $\overline{A C}$ & $\overline{A M}$ & $\overline{P G}$ & $\overline{D M}$ & $\overline{A F}$ & $\overline{D F}$ & $\overline{A C}$ \\
\hline $2: 8$ & $0,48^{\star}$ & $-0,37$ & & & & $0,78^{\star \star}$ & $0,48^{*}$ & $-0,36$ & & & & $0,72^{\star \star}$ \\
\hline $2: 9$ & $0,57^{\star \star}$ & $-0,73^{\star \star}$ & $-0,40$ & $0,41^{*}$ & $0,59^{\star \star}$ & $0,49^{*}$ & $0,65^{\star \star}$ & $-0,65^{\star \star}$ & $-0,33$ & $0,45^{\star}$ & $0,55^{\star \star}$ & $0,70^{\star \star}$ \\
\hline 2:10 & $0,49^{\star}$ & $0,58^{\star \star}$ & & 0,30 & $0,52^{\star \star}$ & & $0,58^{\star *}$ & $-0,50^{*}$ & & $0,53^{\star *}$ & $0,75^{\star \star}$ & \\
\hline $2: 11$ & 0,27 & $-0,65^{\star \star}$ & 0,00 & 0,19 & $0,58^{\star \star}$ & & 0,28 & $-0,59^{\star \star}$ & 0,07 & 0,23 & $0,60^{\star \star}$ & \\
\hline Conj. & $0,50^{*}$ & $-0,63^{\star \star}$ & $-0,25$ & 0,28 & $0,53^{\star \star}$ & $0,72^{\star \star}$ & $0,51^{\star \star}$ & $-0,47^{\star}$ & $-0,12$ & $0,45^{\star}$ & $0,58^{\star \star}$ & $0,74^{\star \star}$ \\
\hline
\end{tabular}

AC - Acamamento; AF - Altura das plantas no florescimento; AM - altura das plantas na maturação; DF dias para o florescimento; DM - dias para a maturação; PG - produção de grãos 
Tabela 56. Coeficientes de correlação de Pearson entre a distância euclidiana especifica com a variância genética das populações e com a proporção de progênies superiores.

\begin{tabular}{|c|c|c|c|c|c|c|c|c|c|c|c|c|}
\hline \multirow[b]{2}{*}{ Pearson } & \multicolumn{6}{|c|}{ DEE vs. variância } & \multicolumn{6}{|c|}{ DEE vs. proporção } \\
\hline & $\overline{A M}$ & PG & $\overline{D M}$ & $\overline{A F}$ & DF & $\overline{A C}$ & AM & $\overline{P G}$ & $\overline{D M}$ & $\mathrm{AF}$ & $\overline{D F}$ & $A C$ \\
\hline$=2: 8$ & 0,12 & $-0,18$ & & & & 0,07 & 0,11 & 0,16 & & & & 0,03 \\
\hline 9 & 0,37 & $-0,19$ & $-0,02$ & 0,08 & 0.06 & 0,09 & 0,23 & 0,00 & $-0,14$ & & & 0,01 \\
\hline & -8 & $\begin{array}{l}-0,02 \\
-0,21\end{array}$ & 0,02 & 0,15 & 0,0 & & 0,09 & $-0,06$ & $-0,13$ & $-0,12$ & & \\
\hline & 0,36 &, 21 & 0,20 & 21 & 27 &, 37 & 0,17 & 0,01 & $-0,25$ & 0,02 & $-0,06$ & 0,04 \\
\hline$\overline{\text { pea }}$ & $\pi$ & $P G$ & $\overline{D M}$ & $\overline{A F}$ & $\bar{F}$ & $A C$ & $\overline{A M}$ & $\overline{P G}$ & $\overline{D M}$ & $\overline{\mathrm{AP}}$ & $\overline{D F}$ & $A C$ \\
\hline 8 & 13 & $-0,40^{*}$ & & & & 0,03 & 0,29 & 0,18 & & & & 0,35 \\
\hline & $0,48^{*}$ & $-0,23$ & $-0,05$ & 0,3 &, 02 & 0,29 & $0,41^{*}$ & $-0,06$ & $-0,21$ & & 0,25 & 0,29 \\
\hline 10 & 0,31 & $-0,47^{\star}$ & & 0,08 & 0,36 & & 0,37 & $-0,14$ & & 0,29 & 0,17 & \\
\hline 11 & 0,08 & $-0,17$ & $-0,13$ & 0,20 & 0,08 & & 0,28 & $-0,14$ & $-0,04$ & 0,09 & 0,17 & \\
\hline onjunta & $0,45^{*}$ & $-0,35$ & 0,11 & 0,21 & 0,31 & 0,27 & 0,33 & $-0,03$ & $-0,16$ & 0,20 & 0,19 & 0,30 \\
\hline
\end{tabular}

AC - Acamamento; AF - Altura das plantas no florescimento; AM - altura das plantas na maturação; DF dias para o florescimento; DM - dias para a maturação; PG - produção de grãos

Caso a seleção fosse realizada pela distância euclidiana geral, ela deveria ser realizada associando as informações que a média dos genitores fornecem. Então, do mesmo modo como foi realizado pela distância euclidiana, as populações selecionadas para maximizar a média da produção de grãos seriam aquelas que apresentassem a menor distância euclidiana geral. Portanto, seriam eleitas as populações $1 \times 3,1 \times 4$, $2 \times 3,3 \times 5$ e $4 \times 5$.

A seleção realizada pela distância euclidiana geral foi semelhante à realizada pela distância euclidiana, diferindo em apenas uma população. A população $2 \times 3$ selecionada pela distância euclidiana geral apresentou melhor desempenho do que a população 2x5, selecionada pela distância euclidiana (Tabela 57).

Portanto, a troca de uma população fez com que a seleção das populações feita pela distância euclidiana geral fosse mais efetiva do que a realizada pela distância euclidiana sem partição. Contudo, como ambas as distâncias apresentam niveis de correlação similares com a proporção de progênies superiores, não é possivel concluir que a partição aumentou o poder de predição da distância euclidiana. Na verdade, a partição manteve estável a capacidade de predição e a vantagem verificada pela sua utilização deve ser função de fatores aleatórios. 
Tabela 57. Proporção de progênies superiores das populações selecionadas pela distância euclidiana geral visando maximizar a produção de grãos das populações e a proporção de progênies superiores média de todas as 25 populações estudadas.

\begin{tabular}{ccccccc}
\hline & AM & PG & DM & AF & DF & AC \\
\hline $1 \times 3$ & 0,10 & 0,90 & 0,90 & 0,55 & 0,30 & 0,15 \\
$1 \times 4$ & 0,00 & 0,69 & 0,38 & 0,00 & 0,00 & 0,08 \\
$2 \times 3$ & 0,55 & 0,85 & 0,75 & 0,55 & 0,40 & 0,10 \\
$3 \times 5$ & 0,05 & 0,85 & 0,55 & 0,15 & 0,05 & 0,00 \\
$4 \times 5$ & 0,05 & 1,00 & 0,65 & 0,25 & 0,25 & 0,20 \\
\hline Média & 0,15 & 0,86 & 0,65 & 0,30 & 0,20 & 0,11 \\
Média (25) & 0,47 & 0,50 & 0,53 & 0,43 & 0,40 & 0,44 \\
\hline
\end{tabular}

$A C$ - Acamamento; AF - Altura das plantas no florescimento; AM - altura das plantas na maturação; DF - dias para o florescimento; DM - dias para a maturação; PG - produção de grãos

4.10.5 Capacidade preditiva da distância genética medida por marcadores RAPD

A distância genética estimada a partir de marcadores RAPD não foi um bom preditor da variância genética das populações, apresentando correlações baixas e com coeficientes não significativos para a maioria dos caracteres (Tabela 58). O melhor desempenho foi verificado para acamamento, contudo, o baixo valor do coeficiente não permite sua utilização para selecionar populações com maior variabilidade.

As médias das populações e a distância genética foram correlacionadas nos caracteres altura das plantas no florescimento, dias para o maturação, acamamento e produção de grãos (Tabela 59). Os valores das correlações foram relativamente altos apenas para produção de grãos, indicando que predições a respeito da média das populações feitas a partir da distância genética seriam mais confiáveis para este caráter.

A maioria das correlações verificadas foi negativa, mostrando que quanto menor a distância entre as linhagens maior foi a média da população. Resultado semelhante foi observado por Kisha et al. (1997), que observaram correlações negativas entre a distância genética baseada em marcadores moleculares e a média das cinco linhagens mais produtivas de um conjunto de populações.

Analisando mais detalhadamente a Tabela 18, verifica-se que as distâncias genéticas tendem a ser menores entre as linhagens adaptadas, a apresentarem 
valores intermediários entre as linhagens adaptadas e não adaptadas e a serem mais altas entre as linhagens não adaptadas. Se a Tabela 27 também for considerada, pode-se observar que a produção de grãos tendeu a ser maior nas populações formadas exclusivamente por genitores adaptados, intermediária quando um dos genitores era adaptado e outro não adaptado e menor quando os dois genitores eram não adaptados. Então, observa-se uma relação inversa entre distância genética e produção média e, portanto, a correlação entre a produção média de grãos das populações e a distância genética foi negativa.

As correlações entre a distância genética e a proporção de progênies superiores das populações foram significativas para produção de grãos e dias para a maturação (Tabela 60). Os valores dos coeficientes foram semelhantes aos obtidos com as médias ajustadas, concordando com os resultados que mostraram que o potencial das populações estava associado quase exclusivamente às médias das populações.

Tabela 58. Coeficientes de correlação de Pearson (P) e Spearman (S) entre a distância genética baseada em marcadores RAPD e a variância genética das populações.

\begin{tabular}{l|cc|cc|ccccccccc}
\hline & \multicolumn{2}{|c}{$A C$} & \multicolumn{2}{c|}{$A F$} & \multicolumn{2}{c|}{$A M$} & \multicolumn{2}{c|}{ DF } & \multicolumn{2}{c|}{$\mathrm{DM}$} & \multicolumn{2}{c}{$\mathrm{PG}$} \\
\hline Geração & $\mathrm{P}$ & $\mathrm{S}$ & $\mathrm{P}$ & $\mathrm{S}$ & $\mathrm{P}$ & $\mathrm{S}$ & $\mathrm{P}$ & $\mathrm{S}$ & $\mathrm{P}$ & $\mathrm{S}$ & $\mathrm{P}$ & $\mathrm{S}$ \\
\hline $\mathrm{F}_{2: 8}$ & 0,28 & 0,25 & & & 0,10 & 0,03 & & & & & $-0,13$ & $-0,08$ \\
$\mathrm{~F}_{2: 9}$ & 0,34 & 0,32 & 0,04 & 0,13 & $0,43^{\star}$ & 0,38 & $-0,18$ & $-0,18$ & $-0,39$ & $-0,23$ & $-0,20$ & $-0,20$ \\
$\mathrm{~F}_{2: 10}$ & & & 0,08 & 0,04 & 0,35 & 0,38 & $-0,06$ & $-0,14$ & & & $-0,05$ & $-0,10$ \\
$\mathrm{~F}_{2: 11}$ & & & 0,05 & 0,09 & 0,35 & 0,36 & $-0,04$ & 0,00 & 0,12 & 0,00 & 0,19 & 0,29 \\
Conjunta & $0,54^{\star}$ & $0,65^{\star}$ & 0,05 & 0,08 & 0,37 & 0,32 & $-0,01$ & $-0,03$ & 0,19 & 0,17 & $-0,04$ & 0,03 \\
\hline
\end{tabular}

$A C$ - Acamamento; AF - Altura das plantas no florescimento; $A \bar{M}$ - altura das plantas na maturação; $\overline{D F}$ dias para o florescimento; DM - dias para a maturação; PG - produção de grãos

Tabela 59. Coeficientes de correlação de Pearson (P) e Spearman (S) entre a distância genética baseada em marcadores RAPD e a média das populações.

\begin{tabular}{|c|c|c|c|c|c|c|c|c|c|c|c|c|}
\hline \multirow[b]{2}{*}{ Geração } & \multicolumn{2}{|c|}{$A C$} & \multicolumn{2}{|c|}{ AF } & \multicolumn{2}{|c|}{ AM } & \multicolumn{2}{|c|}{ DF } & \multicolumn{2}{|c|}{$D M$} & \multicolumn{2}{|c|}{$P G$} \\
\hline & $P$ & $S$ & $P$ & $S$ & $P$ & $S$ & $\mathrm{P}$ & $S$ & $P$ & $S$ & $\mathrm{P}$ & $S$ \\
\hline$\overline{F_{2: 8}}$ & $0,46^{*}$ & $0,50^{*}$ & & & 0,09 & $-0,02$ & & & & & $-0,61^{\star \star}$ & $-0,73^{\star \star}$ \\
\hline $\begin{array}{l}F_{2: 9} \\
F_{2: 10} \\
F_{2: 11}\end{array}$ & 0,33 & 0,37 & $\begin{array}{l}-0,29 \\
-0,51^{\star \star} \\
-0,41^{\star}\end{array}$ & $\begin{array}{c}-0,43^{\star} \\
-0,60^{\star \star} \\
-0,50^{\star}\end{array}$ & $\begin{array}{l}0,09 \\
0,04 \\
-0,05\end{array}$ & $\begin{array}{l}-0,02 \\
-0,05 \\
-0,08\end{array}$ & $\begin{array}{l}-0,16 \\
-0,18 \\
-0,19\end{array}$ & $\begin{array}{l}-0,14 \\
-0,37 \\
-0,17\end{array}$ & $\begin{array}{l}-0,57^{\star \star} \\
-0,51^{\star \star}\end{array}$ & $\begin{array}{l}-0,63^{\star \star} \\
-0,46^{\star}\end{array}$ & $\begin{array}{l}-0,64^{\star \star} \\
-0,77^{\star \star} \\
-0,77^{\star \star}\end{array}$ & $\begin{array}{l}-0,64^{\star \star} \\
-0,79^{\star \star} \\
-0,80^{\star \star}\end{array}$ \\
\hline Conjunta & $0,45^{\star}$ & $0,54^{\star \star !}$ & $-0,44^{*}$ & $-0,60 * \star$ & 0,05 & $-0,08$ & $-0,18$ & $-0,25$ & $-0,62^{\star \star}$ & $-0,66^{\star \star}$ & $-0,74^{\star \star}$ & $-0,78^{\star \star}$ \\
\hline
\end{tabular}


Tabela 60. Coeficientes de correlação de Pearson (P) e Spearman (S) entre a distância genética baseada em marcadores RAPD e a proporção de progênies superiores das populações.

\begin{tabular}{|c|c|c|c|c|c|c|c|c|c|c|c|c|}
\hline \multirow[b]{2}{*}{ Geração } & \multicolumn{2}{|c|}{$A C$} & \multicolumn{2}{|c|}{ AF } & \multicolumn{2}{|c|}{ AM } & \multicolumn{2}{|c|}{$\mathrm{DF}$} & \multicolumn{2}{|c|}{$\overline{D M}$} & \multicolumn{2}{|c|}{$P G$} \\
\hline & $P$ & $S$ & $P$ & $S$ & $P$ & $S$ & $P$ & $\mathrm{~S}$ & $P$ & $S$ & $P$ & $S$ \\
\hline$\overline{F_{2: 8}}$ & $0,42^{\star}$ & $0,41^{\star}$ & & & 0,13 & $-0,01$ & & & & & $-0,62^{\star \star}$ & $-0,69^{\star \star}$ \\
\hline $\begin{array}{l}F_{2: 9} \\
F_{2: 00}\end{array}$ & 0,21 & 0,23 & $\begin{array}{l}-0,25 \\
-0,27\end{array}$ & $\begin{array}{l}-0,34 \\
-0,24\end{array}$ & $\begin{array}{l}0,17 \\
0,19\end{array}$ & $\begin{array}{l}0,03 \\
0,05\end{array}$ & $\begin{array}{l}-0,15 \\
-0,01\end{array}$ & $\begin{array}{c}-0,17 \\
0,02\end{array}$ & $-0,44^{*}$ & $-0,43$ & $\begin{array}{l}-0,55^{\star \star} \\
-0,77^{\star \star}\end{array}$ & $\begin{array}{l}-0,60^{\star \star} \\
-0,78^{\star \star}\end{array}$ \\
\hline$F_{2: 11}$ & & & $-0,39$ & $-0,49^{*}$ & 0,02 & $-0,04$ & $-0,20$ & $-0,21$ & $-0,43^{*}$ & $-0,36$ & $-0,77^{\star \star}$ & $-0,82^{\star \star}$ \\
\hline Conjunta & 0,32 & 0,32 & $-0,30$ & $-0,36$ & 0,10 & $-0,10$ & $-0,11$ & $-0,12$ & $-0,57^{\star \star}$ & $-0,62^{*}$ & $-0,75^{\star \star}$ & $-0,82^{\star \star}$ \\
\hline
\end{tabular}

Se uma seleção fosse realizada utilizando como parâmetro a distância genética e o objetivo desta seleção fosse formar apenas as populações com maior variância genética, não seriam obtidos bons resultados por dois motivos: a) a distância genética não está correlacionada com a variância genética; b) o potencial das populações é determinado quase que exclusivamente pela média.

Caso fosse conhecido que as linhagens não adaptadas são menos produtivas do que as linhagens adaptadas, poderíamos inferir que a distância genética apresentaria correlações negativas com a média das populações. Também seria possivel inferir que a média seria bastante importante para determinar o desempenho das populações. Deste modo, ao invés da seleção entre populações ser realizada para maximizar a variância, ela poderia ser realizada para maximizar a média das populações. Neste caso, as populações que seriam obtidas e avaliadas seriam as que

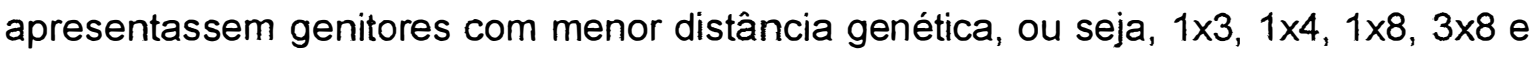
$4 \times 5$.

A população $1 \times 8$ pertence ao grupo de populações com produçãos intermediárias e todas as demais selecionadas estão entre as mais produtivas. Como a proporção de progênies superiores está muito correlacionada com a média das populações, a escolha da população $1 \times 8$ seria o único erro apresentado por esta seleção (Tabela 61).

A acurácia desta seleção foi semelhante à apresentada pela média dos genitores e pela distância euclidiana e um pouco inferior à realizada utilizando a capacidade geral de combinação estimada em $F_{2}$ e pela distância euclidiana geral. A 
eficiência de seleção observada condiz parcialmente com a confiabilidade das predições realizadas pelos diferentes métodos.

Tabela 61. Proporção de progênies superiores das populações selecionadas pela distância genética, visando maximizar a média do caráter produção de grãos.

\begin{tabular}{ccccccc}
\hline & AM & $P G$ & $D M$ & AF & DF & AC \\
\hline $1 \times 3$ & 0,10 & 0,90 & 0,90 & 0,55 & 0,30 & 0,15 \\
$1 \times 4$ & 0,00 & 0,69 & 0,38 & 0,00 & 0,00 & 0,08 \\
$1 \times 8$ & 0,75 & 0,50 & 0,75 & 0,90 & 0,80 & 0,70 \\
$3 \times 8$ & 0,80 & 0,90 & 0,70 & 0,90 & 0,85 & 0,40 \\
$4 \times 5$ & 0,05 & 1,00 & 0,65 & 0,25 & 0,25 & 0,20 \\
\hline Média & 0,34 & 0,80 & 0,68 & 0,52 & 0,44 & 0,31 \\
Média (25) & 0,47 & 0,50 & 0,53 & 0,43 & 0,40 & 0,44 \\
\hline
\end{tabular}

AC - Acamamento; AF - Altura das plantas no florescimento; AM - altura das plantas na maturação; DF dias para o florescimento; DM - dias para a maturação; PG - produção de grãos

Para a produção de grãos, as correlações entre a distância genética e a proporção de progênies superiores foram maiores do que as obtidas pela distância euclidiana e a distância euclidiana geral, um pouco superiores às observadas com a média dos genitores e inferiores às alcançadas pela capacidade geral de combinação estimada em $F_{2}$. Portanto, a predição quanto ao potencial das populações em relação à produção de grãos realizada pela distância genética estimada a partir de marcadores moleculares RAPD não foi superior somente à realizada pela capacidade geral de combinação estimada em $F_{2}$.

A distância genética não seria capaz de realizar predições confiáveis a respeito dos demais caracteres, pois as correlações foram fracas ou apresentaram comportamento errático ao longo dos anos de avaliação.

Não se buscou determinar os fatores que contribuíram para que a distância genética baseada em marcadores fosse mais correlacionada com a produção de grãos do que com caracteres geneticamente mais simples e menos influenciados pelo ambiente. Diversas hipóteses foram formuladas, mas alguns atributos que devem estar simultaneamente presentes apenas na produção de grãos predispuseram a aceitar uma das hipóteses como a mais plausível. 
É bastante provável que a produção de grãos seja controlada por um grande número de QTL's. Estes QTL's devem estar distribuídos pelo genoma de maneira razoavelmente homogênea e não devem existir diferenças muito grandes em seus efeitos.

Os demais caracteres devem apresentar um número restrito de QTL's e para alguns caracteres devem existir QTL's com efeito suficientemente grande para serem classificados como genes de efeito principal. Com um menor número de QTL's atuando e com maiores diferenças entre os efeitos, espera-se que algumas regiões do genoma sejam mais importantes para a expressão do caráter do que outras.

Lembrando que os marcadores RAPD realizam uma amostragem casualizada de todo o genoma, é provável que as diferentes regiões dos cromossomos estejam igualmente representadas nas estimativas de distância genética baseadas em grande número de marcadores. Deste modo, a distribuição dos marcadores RAPD é mais similar a caracteres mais complexos do que com caracteres mais simples e as correlações entre a distância genética baseada em marcadores RAPD devem ser maiores com a produção de grãos do que com os demais caracteres estudados.

4.10.6 Capacidade preditiva da distância genética geral e da distância genética especifica

A soma das distâncias genéticas gerais $\left(D G G_{i}+D G G_{j}\right)$ apresentou correlações com a média das populações em quatro caracteres e com a proporção de progênies superiores em dois caracteres (Tabela 62). Todas as correlações observadas com a distância genética geral também estavam presentes com a distância genética íntegra. Os coeficientes de correlação de Pearson foram sempre maiores na distância genética geral, mas não os de Spearman que permaneceram estáveis. O maior aumento foi verificado com a produção de grãos, cuja correlação proporção de progênies superiores passou de 0,75 para 0,80. Portanto, a partição foi capaz de aumentar um pouco a capacidade de predição da magnitude da proporção de progênies superiores das populações, mas não da classificação relativa das populações.

A variância genética e a proporção de progênies superiores foram independentes da distância genética específica (Tabela 63). Deste modo, uma seleção 
baseada na distância genética especifica para maximizar a variância das populações seria inefetiva.

Tabela 62. Coeficientes de correlação de Pearson e Spearman entre a soma das distâncias genéticas gerais $\left(D G G_{i}+D G G_{j}\right)$ e a média ajustada das populações e a proporção de progênies superiores.

\begin{tabular}{|c|c|c|c|c|c|c|c|c|c|c|c|c|}
\hline \multirow[b]{2}{*}{ Pearson } & \multicolumn{6}{|c|}{ DGG vs. média } & \multicolumn{6}{|c|}{ DGG vs. proporção } \\
\hline & AM & $P G$ & DM & $\mathrm{AF}$ & DF & $A C$ & $\overline{A M}$ & $P G$ & DM & $\mathrm{AF}$ & DF & $A C$ \\
\hline$\overline{F_{2: 8}}$ & 0,03 & $-0,62^{\star \star}$ & & & & $0,52^{\star \star}$ & 0,02 & $-0,66^{\star \star}$ & & & & $0,46^{\star}$ \\
\hline$F_{2: 9}$ & 0,07 & $-0,64^{\star \star}$ & $-0,65^{\star \star}$ & $-0,31$ & $-0,21$ & 0,37 & 0,06 & $-0,65^{\star \star}$ & $-0,48^{\star}$ & $-0,28$ & $-0,19$ & 0,25 \\
\hline$F_{2: 10}$ & $-0,10$ & $-0,83^{\star \star}$ & & $-0,50^{\star}$ & $-0,14$ & & 0,08 & $-0,76^{\star \star}$ & & $-0,29$ & $-0,04$ & \\
\hline$F_{2: 11}$ & $-0,02$ & $-0,83^{\star \star}$ & $-0,59^{\star \star}$ & $-0,48^{\star}$ & $-0,25$ & & $-0,08$ & $-0,80^{\star \star}$ & $-0,50^{*}$ & $-0,45^{\star}$ & $-0,24$ & \\
\hline Conjunta & 0,00 & $-0,78^{\star \star}$ & $-0,72^{\star *}$ & $-0,47^{*}$ & $-0,21$ & $0,50^{*}$ & $-0,03$ & $-0,80^{\star \star}$ & $-0,59^{\star \star}$ & $-0,31$ & $-0,14$ & 0,34 \\
\hline Spearman & AM & $P G$ & DM & $\overline{A F}$ & $\mathrm{DF}$ & $A C$ & AM & $P G$ & $\overline{D M}$ & $\mathrm{AF}$ & DF & $\overline{A C}$ \\
\hline$\overline{F_{2: 8}}$ & 0,03 & $-0,72^{\star \star}$ & & & & $-0,54^{\star \star}$ & 0,02 & $-0,64^{*}$ & & & & 0,43 \\
\hline$F_{2: 9}$ & $-0,08$ & $-0,62^{\star \star}$ & $-0,67^{\star \star}$ & $-0,32$ & $-0,19$ & 0,38 & 0,05 & $-0,65^{\star}$ & $-0,46^{\star}$ & $-0,27$ & $-0,18$ & 0,25 \\
\hline$F_{2: 10}$ & 0,02 & $-0,83^{\star \star}$ & & $-0,51^{\star \star}$ & $-0,25$ & & 0,06 & $-0,78^{\star \star}$ & & $-0,226$ & 0,04 & \\
\hline$F_{2: 11}$ & 0,04 & $-0,83^{\star \star}$ & $-0,58^{\star \star}$ & $-0,44^{\star}$ & $-0,23$ & & $-0,11$ & $-0,80^{\star \star}$ & $-0,53^{\star \star}$ & $-0,47^{\star}$ & $-0,21$ & \\
\hline Conjunta & $-0,03$ & $-0,77^{\star \star}$ & $-0,66^{* \star}$ & $-0,50^{\star \star}$ & $-0,25$ & $0,57^{\star \star}$ & $-0,13$ & $-0,82^{\star \star}$ & $-0,66^{\star \star}$ & $-0,34$ & $-0,11$ & 0,36 \\
\hline
\end{tabular}

Tabela 63. Coeficientes de correlação de Pearson e Spearman entre a distância genética especifica e a variância genética das populações e com a proporção de progênies superiores.

\begin{tabular}{|c|c|c|c|c|c|c|c|c|c|c|c|c|}
\hline \multirow[b]{2}{*}{ Pearson } & \multicolumn{6}{|c|}{ DGE vs. variância } & \multicolumn{6}{|c|}{ DGE vs. proporção } \\
\hline & $A M$ & $P G$ & $\overline{D M}$ & $\mathrm{AF}$ & $\overline{D F}$ & $A C$ & $\overline{A M}$ & $P G$ & DM & $\mathrm{AF}$ & $\mathrm{DF}$ & $A C$ \\
\hline $\mathrm{F}_{2: 8}$ & 0,25 & $-0,10$ & & & & $-0,10$ & 0,22 & $-0,21$ & & & & 0,05 \\
\hline$F_{2: 9}$ & 0,30 & $-0,32$ & $-0,36$ & 0,28 & $-0,04$ & $-0,10$ & 0,20 & $-0,05$ & $-0,12$ & $-0,07$ & $-0,10$ & $-0,01$ \\
\hline$F_{2: 10}$ & 0,26 & $-0,26$ & & 0,15 & 0,05 & & 0,23 & $-0,19$ & & $-0,08$ & 0,03 & \\
\hline$F_{2 \cdot 11}$ & 0,13 & $-0,05$ & 0,20 & 0,01 & $-0,27$ & & 015 & $-0,24$ & $-0,04$ & $-0,08$ & $-0,04$ & \\
\hline Conjunta & 0,31 & $-0,15$ & 0,18 & 0,14 & 0,02 & 0,13 & 0,22 & $-0,21$ & $-0,19$ & $-0,11$ & $-0,02$ & 0,05 \\
\hline Spearman & $A M$ & $\overline{P G}$ & $\overline{D M}$ & $\overline{A F}$ & $\overline{D F}$ & $\overline{A C}$ & $\overline{A M}$ & $P G$ & $\overline{D M}$ & $\overline{A F}$ & $\overline{D F}$ & $\overline{A C}$ \\
\hline$\overline{F_{2: 8}}$ & 0,22 & $-0,28$ & & & & $-0,12$ & 0,06 & $-0,14$ & & & & $-0,03$ \\
\hline$F_{29}$ & 0,35 & $-0,28$ & $-0,33$ & 0,31 & $-0,06$ & $-0,02$ & 0,02 & 0,03 & $-0,04$ & $-0,24$ & 0,02 & $-0,02$ \\
\hline$F_{2: 10}$ & 0,31 & $-0,41$ & & 0,13 & $-0,22$ & & 0,08 & $-0,10$ & & 0,04 & $-0,01$ & \\
\hline$F_{2: 11}$ & 0,14 & 0,00 & 0,09 & 0,14 & $-0,17$ & & 0,12 & $-0,21$ & 0,15 & $-0,15$ & 0,02 & \\
\hline Conjunta & 0,33 & $-0,19$ & 0,10 & 0,32 & 0,09 & 0,12 & 0,07 & $-0,13$ & $-0,16$ & $-0,06$ & 0,05 & $-0,04$ \\
\hline
\end{tabular}

AC - Acamamento; AF - Altura das plantas no florescimento; AM - altura das plantas na maturação; DF dias para o florescimento; DM - dias para a maturação; PG - produção de grãos 
Para que as informações fornecidas pela distância genética geral possam ser utilizadas, é necessário que se verifique qual deve ser o sentido das correlações com a média das populações. Isto pode ser realizado utilizando o mesmo expediente empregado para a distância genética íntegra. Seria observado que deve existir uma correlação negativa entre a soma das distâncias genéticas gerais e a média das populações. Então, pode-se tentar realizar uma seleção visando maximizar a média da produção de grãos das populações. Com base nas menores distâncias genéticas gerais, seriam selecionadas as populações $1 \times 3,1 \times 4,1 \times 8,3 \times 8$ e $4 \times 8$.

Entre estas populações, a única que não pertence ao grupo mais produtivo é a $1 \times 8$ (Tabela 27). O comportamento das populações selecionadas pode ser observado na Tabela 64. Comparando estas populações com as selecionadas pela distância genética, verifica-se que houve a troca de apenas uma população, a 4x8 substituiu a 4x5. Como ambas as populações possuem proporções de progênies superiores semelhantes, conclui-se que a seleção realizada pela distância genética geral apresentou mesma eficiência que a realizada pela distância genética integra.

Os pequenos aumentos das correlações verificadas após a partição foram suficientes para aumentar, embora pouco, a confiabilidade das predições realizadas pela distância genética baseada em marcadores RAPD quanto à produção de grãos, mas não para os demais caracteres. Esta conclusão pode ser válida apenas para este conjunto de populações. Portanto, é recomendável que um número maior de estudos seja realizado para verificar se a partição da distância genética proporciona alguma vantagem em relação à utilização da estimativa integra.

Tabela 64. Proporção de progênies superiores das populações selecionadas pela distância genética geral e a proporção média de progênies superiores em todas as 25 populações.

\begin{tabular}{ccccccc}
\hline & AM & PG & DM & AF & DF & AC \\
\hline $1 \times 3$ & 0,10 & 0,90 & 0,90 & 0,55 & 0,30 & 0,15 \\
$1 \times 4$ & 0,00 & 0,69 & 0,38 & 0,00 & 0,00 & 0,08 \\
$1 \times 8$ & 0,75 & 0,50 & 0,75 & 0,90 & 0,80 & 0,70 \\
$3 \times 8$ & 0,80 & 0,90 & 0,70 & 0,90 & 0,85 & 0,40 \\
$4 \times 8$ & 0,90 & 0,95 & 0,60 & 0,95 & 1,00 & 0,80 \\
\hline Média & 0,51 & 0,79 & 0,67 & 0,66 & 0,59 & 0,43 \\
Média (25) & 0,47 & 0,50 & 0,53 & 0,43 & 0,40 & 0,44 \\
\hline
\end{tabular}

AC - Acamamento; AF - Altura das plantas no florescimento; AM - altura das plantas na maturação; DF dias para o florescimento; DM - dias para a maturação; PG - produção de grãos 
4.11 Considerações a respeito das predições realizadas considerando todas as 25 populações

Nenhuma medida de diversidade genética foi capaz de predizer a magnitude da variância genética das populações. Em todos os casos as correlações foram não significativas ou apresentaram valores baixos. Estes resultados concordam com quase todos os trabalhos que tentaram predizer a variância genética de populações de soja (Helms et al., 1997; Kisha et al. 1997; Manjarrez-Sandoval et al., 1997b).

Conforme Gumber at al. (1999), a ausência de correlações entre a variância genética e as estimativas de diversidade pode ter origem em três causas principais: i) inacurácia das estimativas de diversidade genética; ii) inacurácia das estimativas de variância genética; iii) a não existência de correlações entre os parâmetros (não estimativas) diversidade genética e variância genética.

Considerando que os QTL's que estão segregando nas populações não devem estar igualmente dispersos pelo genoma e que seus efeitos não devem ser iguais, predições confiáveis à respeito da variância genética só podem ser obtidas caso o método de quantificação da diversidade consiga identificar estas particularidades (Bernardo, 1992, Charcosset \& Essioux, 1994). É bastante improvável que a distância genética obtida pela análise dos marcadores RAPD e a distância euclidiana tenham conseguido realizar uma amostragem do genoma dos genitores segundo o modo necessário para obter correlações altas. Portanto, predições a respeito da magnitude da variância genética com base nestes dois métodos só poderiam ser não efetivas. De qualquer forma, é necessário conhecer a validade dos métodos

Os intervalos de confiança associados às estimativas da variância genética foram altos. Portanto, a precisão destas estimativas deve ter sido baixa. Conforme já discutido, a falta de precisão das estimativas de variância genética pode estar associada a problemas experimentais. Se as estimativas de variância genética não são precisas ou apresentam viés, é muito difícil obter correlações significativas com estimativas de diversidade.

Cabe considerar que as condições presentes nos experimentos utilizados neste estudo são semelhantes às existentes na maioria dos programas de melhoramento de soja. Portanto, a variância genética utilizada no melhoramento da soja deve apresentar os mesmos problemas encontrados nestes estudos. Neste caso, os 
métodos de predição não devem estar dirigidos à variância genética potencial (aquela obtida a partir de um grande tamanho efetivo e na ausência de seleção natural, deriva, migração e mutação) mas sim à variância genética realizada, ou seja, a que estará presente no momento da seleção. Assim, o estudo das populações em $F_{3}$ desprezando os efeitos de dominância (Jinks \& Pooni, 1980; Toledo, 1987; Triller \& Toledo, 1996) devem apresentar melhor capacidade de predizer a variância das populações do que as metodologias baseadas na análise da diversidade dos genitores.

Caso as 25 populações analisadas neste estudo fossem semelhantes às consideradas ideais por Cox et al. (1985), ou seja, todas com médias altas, a ausência de correlações significativas com a variância genética impediria que predições fossem realizadas a seu respeito. Contudo, foi verificado que as diferenças entre as médias das populações foram grandes o suficiente para que a variância genética tivesse importância secundária na classificação das populações. Portanto, para este conjunto fixo de populações, as correlações entre as estimativas de diversidade com a média das populações seriam de maior utilidade do que as correlações com a variância genética.

A comparação entre a média das populações e os métodos de predição testados permitiu observar a presença de correlações significativas e suficientemente altas para que fossem realizadas predições. Considerando todos os caracteres, as maiores capacidades de predição foram verificadas pela média dos genitores e as capacidades gerais de combinação estimadas em $F_{2}$. $O$ primeiro método tem sido amplamente utilizado para formar as populações de soja (Thorne \& Fehr, 1970; Schoener \& Fehr, 1979; Toledo, 1987; Triller \& Toledo, 1996; Helms et al, 1997; Manjarrez-Sandoval et al., 1997b; Kisha et al., 1997). Porém, o segundo pouco tem sido utilizado. Um dos relatos encontrados na literatura foi realizado por Pulcinelli (1997), que realizou esta análise utilizando os mesmos dados empregadas neste estudo em dois caracteres. Portanto, os resultados e conclusões a respeito da capacidade geral de combinação estimada em $F_{2}$ para os caracteres produção de grãos e altura das plantas na maturação não são inéditos.

A média dos genitores não foi capaz de predizer que algumas populações obtidas a partir do cruzamento de linhagens adaptadas com a linhagem não adaptada 8 apresentaria altas proporções de progênies superiores. Portanto, uma informação 
importante a respeito do comportamento das populações não foi predita a partir deste método.

Os piores resultados foram obtidos pela distância euclidiana, que não apresentou correlações altas o suficiente para que predições confiáveis pudessem ser realizadas. A partição desta distância em componentes geral e especifico não resultou em aumento da confiabilidade das predições. Todavia, a seleção simulada para produção de grãos mostrou que a distância euclidiana integra e geral foram capazes de realizar seleções efetivas. É provável que a efetividade da seleção se deva às grandes diferenças existentes entre as populações estudadas. O baixo nivel de correlação observado com a proporção de progênies superiores deve impedir que a seleção seja efetiva se realizada em populações um pouco mais semelhantes.

A distância genética baseada em marcadores RAPD foi capaz de realizar predições razoavelmente confiáveis apenas para a produção de grãos. Ao contrário da média dos genitores e da capacidade geral de combinação estimada em $F_{2}$, apenas uma estimativa de distância é utilizada para predizer o comportamento de todos os caracteres. Como os caracteres quantitativos não apresentam o mesmo comportamento, é impossivel que existam correlações entre a distância genética com todos os caracteres. Portanto, deve-se buscar estimativas de distância que estejam correlacionadas com os caracteres mais importantes para a espécie, que no caso da soja é, sem dúvida, a produção de grãos.

A partição das distâncias genéticas baseadas em marcadores possibilitou que fossem obtidos pequenos aumentos nos coeficientes de correlação com a proporção de progênies superiores. Estes aumentos foram maiores com o coeficiente de Pearson do que com o de Spearman. Porém, não foram suficientes para que as predições se tornassem substancialmente mais confiáveis em outros caracteres que não a produção de grãos.

O desempenho da distância genética geral baseada em marcadores RAPD em predizer o potencial das populações quanto à produção de grãos foi ligeiramente superior ao observado pela média dos genitores e ligeiramente inferior ao da capacidade geral em $F_{2}$. Portanto, a distância genética e a distância genética geral poderiam ser utilizadas para predizer o comportamento destas populações quanto à produção de grãos. Se os resultados e predições precisam ser obtidos com rapidez, sua utilização é ainda mais recomendável. 
4.12 Predições a respeito do comportamento das 14 populações endogâmicas formadas pelo cruzamento entre genitores adaptados com não adaptados.

4.12.1 Capacidade preditiva da média dos genitores

A média dos genitores apresentou altas correlações com as médias e com a proporção de progênies superiores das populações para a maioria dos caracteres estudados (Tabela 65). As menores correlações foram obtidas para produção de grãos, que não foram significativas em algumas das avaliações realizadas.

Observando a produção dos genitores na Tabela 3, verifica-se que no ano de 1996/97 e na análise conjunta as médias das linhagens genitoras não adaptadas não puderam ser diferenciadas segundo o teste de Tukey. Contudo, o teste de Tukey encontrou diferenças significativas entre os níveis de produção de grãos destas linhagens no experimento realizado em 1997/98. Caso sejam utilizados os resultados de 1997/98 ao invés da análise conjunta, as correlações com a média das populações e a proporção de progênies superiores tornam-se mais altas e quase sempre significativas (Tabela 66). Isto pode ser um indicativo que a avaliação em 1997/98 representa melhor a capacidade produtiva das linhagens não adaptadas. A avaliação em 1996/97 deve ter apresentado uma grande interação dos genótipos não adaptados com as condições experimentais verificadas neste ano, influenciando muito os resultados obtidos na análise conjunta. Caso isto tenha ocorrido, mais anos de experimentação seriam necessários para obter estimativas mais consistentes da média dos genitores.

Outros autores também concluíram que a desempenho per se de linhagens não adaptadas pode ser utilizado para escolher o melhor genitor (St. Martin \& Aslam, 1986; Scott \& Kephard, 1997). Portanto, os resultados obtidos encontram suporte na literatura. 
Tabela 65. Coeficientes de correlação de Pearson e Spearman entre a média dos genitores e a média das populações, considerando as 14 populações formadas pelo cruzamento entre uma linhagem adaptada com outra não adaptada.

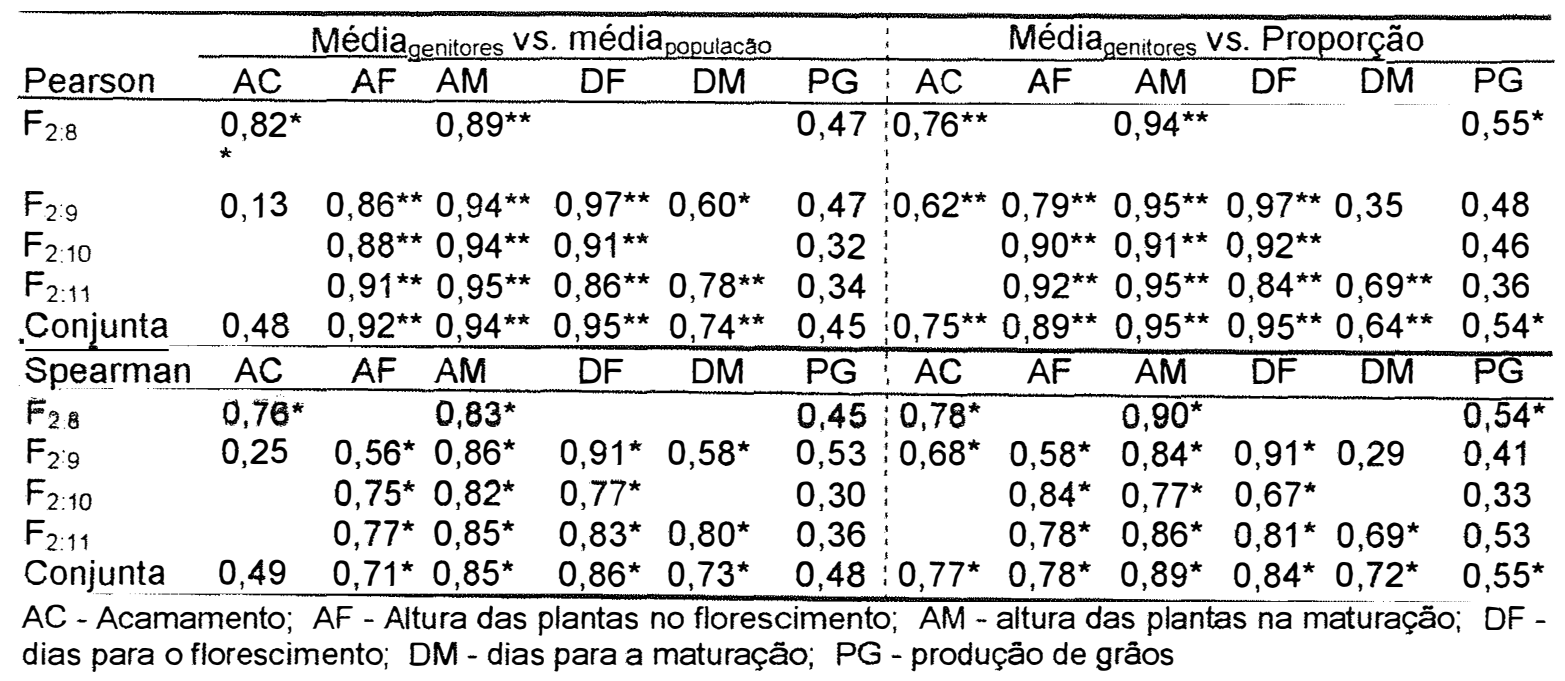

Tabela 66. Correlações entre a média dos genitores na avaliação realizada em 1997/98 e a média das populações e a proporção de progênies superiores, para o caráter produção de grãos.

\begin{tabular}{lccccc}
\hline & $F_{2: 8}$ & $F_{2: 9}$ & $F_{2: 10}$ & $F_{2: 11}$ & Conjunta \\
Média & $0,61^{\star \star}$ & $0,67^{\star \star}$ & 0,49 & $0,63^{\star \star}$ & $0,65^{\star \star}$ \\
Proporção & $0,66^{\star \star}$ & $0,72^{\star \star}$ & $0,59^{\star}$ & $0,67^{\star \star}$ & $0,70^{\star \star}$ \\
\hline
\end{tabular}

Caso se deseje escolher apenas um genitor não adaptado para ser cruzado com os cinco adaptados, a seleção para o caráter produção de grãos com base na média dos genitores no ano de $1997 / 98$ elegeria a linhagem 8. Portanto, as populações obtidas seriam: $1 \times 8,2 \times 8,3 \times 8,4 \times 8$ e $5 \times 8$.

Pelos valores observados na Tabela 67, percebe-se que a seleção foi efetiva, ou seja o genitor não adaptado mais produtivo foi escolhido. Seleções semelhantes poderiam ser realizadas para os demais caracteres e a média dos genitores sempre seria capaz de selecionar o genitor mais adequado às necessidades do programa de melhoramento. 
Portanto, as predições com base na média dos genitores foram efetivas em todos os caracteres. Porém, é necessário que os genitores estejam muito bem avaliados, principalmente para os caracteres onde a interação com o ambiente é mais alta.

Tabela 67. Média e proporções de progênies superiores das populações selecionadas, de todas as 14 populações e a razão entre as duas médias.

\begin{tabular}{c|ccc:cccc}
\hline & \multicolumn{3}{c}{ Média } & \multicolumn{3}{c}{ Proporção } \\
\hline Caráter & Selecionadas & Todas & Sel. $/$ Todas & Selecionadas & Todas & Sel. Todas \\
\hline PG & 205,34 & 177,95 & 1,15 & 0,69 & 0,39 & 1,77 \\
AM & 85,33 & 75,88 & 1,12 & 0,82 & 0,50 & 1,64 \\
AF & 65,86 & 56,77 & 1,16 & 0,90 & 0,47 & 1,91 \\
DF & 58,22 & 54,84 & 1,06 & 0,90 & 0,46 & 1,96 \\
DM & 130,18 & 129,16 & 1,01 & 0,75 & 0,45 & 1,67 \\
AC & 1,81 & 1,71 & 1,06 & 0,73 & 0,54 & 1,35 \\
\hline
\end{tabular}

AC - Acamamento; AF - Altura das plantas no florescimento; AM - altura das plantas na maturação; DF dias para o florescimento; DM - dias para a maturação; PG - produção de grãos

\subsubsection{Capacidade preditiva do dialelo parcial em $F_{2}$}

Excetuando o caráter acamamento, os demais apresentaram correlações altas entre as estimativas da capacidade geral de combinação obtidas nas populações $F_{2} e$ nas populações endogâmicas (Tabela 68). Sendo a capacidade geral de combinação uma medida dos efeitos genéticos aditivos, pode-se concluir que não houve alterações substanciais nas estimativas deste efeitos obtidas em $F_{2}$ e $F_{2: n}$. Isto indica que, caso fosse desejado conhecer os efeitos aditivos dos genótipos adaptados e dos genótipos não adaptados, não seria necessário avançar as populações além de $F_{2}$.

Os efeitos da capacidade específica estimada na geração $F_{2}$ e nas gerações com endogamia mais alta foram quase sempre independentes. As razões para a inexistência de correlações devem ser os mesmos discutidos quando esta análise foi 
realizada considerando as 25 populações, ou seja, a presença de efeitos não homogêneos de dominância em $F_{2}$ e sua ausência em gerações com elevado nivel de endogamia.

As correlações da soma dos efeitos da capacidade geral de combinação $\left(g_{i}+g_{j}\right)$ com a média das populações e com a proporção de progênies superiores foram sempre altas, à exceção de acamamento (Tabela 69). Isto confirma os resultados obtidos pela análise do dialelo parcial, que mostrou que o componente aditivo das médias dos dois grupos de linhagens (adaptadas e não adaptadas) são os principais responsáveis pelas diferenças entre as médias das populações.

As capacidades específicas de combinação estimadas em $F_{2: 10}$ do caráter altura das plantas no florescimento e da análise conjunta do número de dias para a maturação foram correlacionadas com a variância genética das populações. As demais estimativas foram independentes (Tabela 70).

Tabela 68. Coeficientes de correlação de Pearson e Spearman entre as capacidades gerais e específicas de combinação estimadas em dialelos parciais nas gerações $F_{2}$ e $F_{2: n}$.

\begin{tabular}{|c|c|c|c|c|c|c|c|c|c|c|c|c|}
\hline \multirow[b]{2}{*}{ Pearson } & \multicolumn{6}{|c|}{$\mathrm{CGC}_{\mathrm{F} 2}$ vs. $\mathrm{CGC}_{\mathrm{F} 2: n}$} & \multicolumn{6}{|c|}{$\mathrm{CEC}_{\mathrm{F} 2}$ vS. CEC $\mathrm{C}_{\mathrm{F} 2 \mathrm{n}}$} \\
\hline & AM & PG & $D M$ & AF & DF & $\overline{A C}$ & $\overline{A M}$ & $\overline{P G}$ & DM & AF & DF & \\
\hline 28 & $0,86^{\star \star}$ & $0,89^{\star \star}$ & & & & 64 & 0,13 & $0,66^{\star \star}$ & & & & , ve \\
\hline & & $084^{\star *}$ & 70 & 0,65 & 9 & 0,01 & 0,03 & 0,11 & 0,17 & $-0,03$ & & 0,02 \\
\hline & & & $0,89^{\star \star}$ & 0,67 & 0,8 & & 0,15 & 0,38 & $-0,02$ & $0,73^{\star \star}$ & & \\
\hline & 91 & 0,93 & & $0,75^{\star}$ & $0,93^{\star \star}$ & & $-0,13$ & 0,15 & & 0,29 & 0 & \\
\hline & $0,90^{\star \star}$ & U & 0,8 & 0,70 & $0,95^{\star \star}$ & 0,37 & 0,03 & 0,43 & 0,08 & 0,49 & & 0,02 \\
\hline pea & AM & & DM & 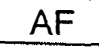 & $\mathrm{DF}$ & $A C$ & $A M$ & $P G$ & DM & AF & & $A C$ \\
\hline 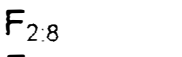 & 76 & 0,83 & & & & 0,61 & 0,14 & $0,63^{\star}$ & & & & 0,0 \\
\hline$\therefore$ & $81^{\star}$ & $0,93^{\star}$ & $0,76^{\star}$ & 0,48 & $0,90^{*}$ & 0,18 & $-0,01$ & 0,01 & 0,13 & $-0,22$ & & 0,05 \\
\hline & $0,81^{\star}$ & 0,60 & & 0,48 & 0,60 & & 0,13 & 0,41 & & $-0,08$ & $-0,26$ & \\
\hline & 76 & 0,98 & $0,90^{*}$ & 0,40 & 0,93 & & $-0,05$ & 0,18 & 0,01 & $-0,56^{\star}$ & & \\
\hline onjunta & $0,79^{\star}$ & 0,95 & $0,90^{\star}$ & 0,55 & $0,83^{\star}$ & 0,45 & 0,06 & 0,50 & 0,09 & $-0,33$ & $-0,44$ &, 1 \\
\hline
\end{tabular}
AC - Acamamento; AF - Altura das plantas no florescimento; AM - altura das plantas na maturação; DF dias para o florescimento; DM - dias para a maturação; PG - produção de grãos 
Tabela 69. Coeficientes de correlação de Pearson e Spearman da soma das capacidades gerais de combinação $\left(g_{i}+g_{i}\right)$ estimadas em $F_{2}$ com a média ajustada das populações e com a proporção de progênies superiores.

\begin{tabular}{|c|c|c|c|c|c|c|c|c|c|c|c|c|}
\hline \multirow[b]{2}{*}{ Pearson } & \multicolumn{6}{|c|}{$\mathrm{CGC}_{\mathrm{F} 2}$ vs. média } & \multicolumn{6}{|c|}{$\mathrm{CGC}_{\mathrm{F} 2}$ vs. proporção } \\
\hline & $A M$ & $P G$ & DM & $\overline{A F}$ & DF & $\overline{A C}$ & $\overline{A M}$ & $P G$ & DM & $\mathrm{AF}$ & DF & $\mathrm{AC}$ \\
\hline $2: 8$ & $0,80^{\star \star}$ & $0,87^{\star \star}$ & & & & $0,57^{\star}$ & $0,87^{\star \star}$ & $0,85^{\star \star}$ & & & & $0,59^{\star}$ \\
\hline $2: 9$ & $0,86^{\star \star}$ & $0,68^{\star \star}$ & $64^{*}$ & $0,73^{\star \star}$ & $0,97^{\star \star}$ & $-0,11$ & $0,90^{\star \star}$ & $0,75^{\star \star}$ & 0,39 & & 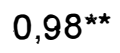 & 0,38 \\
\hline $2: 10$ & $0,89^{\star \star}$ & $0,66^{\star \star}$ & & $0,75^{\star \star}$ & $0,89^{\star \star}$ & & $0,88^{\star \star}$ & $0,59^{\star \star}$ & & $0,84^{\star \star}$ & 0.9 & \\
\hline 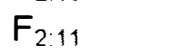 & $0,88^{\star \star}$ & $0,93^{\star \star}$ & $0,83^{\star \star}$ & $0,82^{\star \star}$ & $0,87^{\star \star}$ & & $0,90^{\star \star}$ & $0,92^{\star \star}$ & $0,74^{\star \star}$ & 0,8 & 0,8 & \\
\hline on & $0,87^{\star \star}$ & $0,87^{\star \star}$ & $0,78^{\star \star}$ & $0,79^{\star \star}$ & $0,94^{\star \star}$ & 0,28 & $0,88^{\star \star}$ & $0,90^{\star \star}$ & $0,68^{\star \star}$ & $0,84^{\star \star}$ & $0,95^{\star \star}$ & $0,54^{*}$ \\
\hline Spe & $\overline{A M}$ & $\overline{P G}$ & $\overline{D M}$ & $\overline{A F}$ & $\overline{D F}$ & $\overline{A C}$ & $\overline{A M}$ & $\overline{P G}$ & $\overline{D M}$ & $\overline{A F}$ & $\overline{D F}$ & $\overline{A C}$ \\
\hline $2: 8$ & $0,64^{\star}$ & $0,84^{\star \star}$ & & & & 0,48 & $0,71^{\star \star}$ & $0,81^{\star \star}$ & & & & $0,55^{\star}$ \\
\hline 9 & $0,68^{\star \star}$ & $0,64^{\star \star}$ & $0,68^{* *}$ & $0,55^{\star}$ & $0,94^{\star \star}$ & 0,24 & $0,66^{\star \star}$ & $0,76^{\star \star}$ & 0,38 & & 0,9 & 0,41 \\
\hline 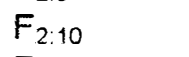 & $0,71^{\star \star}$ & $0,73^{\star \star}$ & & $0,56^{\star}$ & 0,75 & & $0,71^{\star \star}$ & $0,67^{\text {** }}$ & & & 0,7 & \\
\hline 2.11 & $67^{\star \star}$ & $0,95^{\star \star}$ & 0 & $0,73^{\star \star}$ & 0,89 & & $0,68^{\star *}$ & $0,87^{\star \star}$ & $0,76^{\star \star}$ & $0,77^{\star \star}$ & $0,88^{\star \star}$ & \\
\hline onjunta & $0,65^{\star \star}$ & $0,86^{\star \star}$ & $0,80^{\star \star}$ & $0,54^{\star}$ & $0,87^{\star \star}$ & 0,35 & $0,70^{\star \star}$ & $0,92^{\star \star}$ & $0,77^{\star *}$ & $0,66^{*}$ & $0,89^{\star *}$ & $0,58^{*}$ \\
\hline
\end{tabular}

AC - Acamamento; AF - Altura das plantas no florescimento; AM - altura das plantas na maturação; DF dias para o florescimento; DM - dias para a maturação; PG - produção de grãos

Tabela 70. Coeficientes de correlação de Pearson e Spearman da capacidade especifica de combinação estimadas em $\mathrm{F}_{2}$ com a variância genética das populações e com a proporção de progênies superiores.

\begin{tabular}{|c|c|c|c|c|c|c|c|c|c|c|c|c|}
\hline \multirow[b]{2}{*}{ Pearson } & \multicolumn{6}{|c|}{$\mathrm{CEC}_{F 2}$ vs. variância } & \multicolumn{6}{|c|}{$\mathrm{CEC}_{\mathrm{F} 2}$ vs. proporção } \\
\hline & AM & $P G$ & $\mathrm{DM}$ & $\overline{A F}$ & $\mathrm{DF}$ & $A C$ & $\overline{A M}$ & $P G$ & $\overline{D M}$ & $\mathrm{AF}$ & $\mathrm{DF}$ & $A C$ \\
\hline$F_{2.8}$ & 0,37 & $-0,26$ & & & & $-0,01$ & 0,29 & 0,06 & & & & 0,45 \\
\hline$F_{2: 9}$ & 0,09 & $-0,46$ & $-0,05$ & $-0,20$ & 0,04 & 0,12 & 0,31 & 0,16 & $-0,16$ & $-0,09$ & $-0,17$ & 0,12 \\
\hline$F_{2: 10}$ & $-0,11$ & $-0,14$ & & $-0,27$ & 0,19 & & 0,33 & $-0,07$ & & $-0,11$ & $-0,02$ & \\
\hline$F_{2: 11}$ & 0,33 & $-0,31$ & $-0,26$ & $-0,59 *$ & 0,49 & & 0,23 & $-0,07$ & $-0,04$ & 0,00 & $-0,16$ & \\
\hline Conjunta & 0,21 & $-0,29$ & $\overline{-}^{-} 7^{\star}$ & $-0,28$ & 0,34 & 0,14 & 0,23 & $-0,11$ & $-0,06$ & $-0,04$ & $-0,07$ & 0,27 \\
\hline Spearman & AM & PG & $\overline{D M}$ & $\overline{A F}$ & $\overline{D F}$ & $\overline{A C}$ & $\overline{A M}$ & $P G$ & $\overline{D M}$ & $\overline{A F}$ & $\overline{D F}$ & $A C$ \\
\hline$\overline{F_{2: 8}}$ & 0,39 & $-0,17$ & & & & 0,26 & 0,22 & $-0,05$ & & & & 0,39 \\
\hline $\mathrm{F}_{2: 9}$ & 0,01 & $-0,51$ & 0,03 & $-0,30$ & $-0,16$ & 0,14 & 0,19 & 0,13 & $-0,33$ & $-0,18$ & $-0,17$ & 0,07 \\
\hline$F_{2: 10}$ & 0,03 & $-0,23$ & & $-0,31$ & 0,06 & & 0,13 & $-0,12$ & & $-0,17$ & 0,04 & \\
\hline$F_{2: 11}$ & 0,28 & $-0,35$ & $-0,01$ & $-0,54^{\star}$ & 0,34 & & 0,12 & 0,04 & $-0,11$ & 0,08 & $-0,12$ & \\
\hline Conjunta & 0,20 & $-0,27$ & $-0,33$ & $-0,20$ & 0,27 & 0,24 & 0,13 & 0,02 & $-0,07$ & $-0,05$ & $-0,06$ & 0,30 \\
\hline
\end{tabular}

AC - Acamamento; AF - Altura das plantas no florescimento; AM - altura das plantas na maturação; DF dias para o florescimento; DM - dias para a maturação; $P G$ - produção de grãos

Se uma seleção baseada nos efeitos da capacidade geral de combinação estimada em $F_{2}$ fosse realizada para escolher qual dos três genitores não adaptados 
produziria populações com melhor desempenho, a linhagem 8 seria a escolhida. Esta é a opção correta. Portanto a seleção seria efetiva.

As predições realizadas pela capacidade geral de combinação seriam corretas para todos os caracteres estudados, menos para acamamento. Portanto, seria possivel escolher com precisão o genitor adequado às necessidades do programa pela análise das populações em $F_{2}$.

Quando comparada à média dos genitores, a capacidade geral de combinação forneceu predições mais confiáveis apenas para produção de grãos. Porém, as predições utilizando a média dos genitores no ano de $1997 / 98$ seriam precisas o suficiente para determinar qual o genitor não adaptado seria mais adequado para obter as melhores populações quanto a produção de grãos. Adicionalmente, a quantidade de trabalho necessária para obter e avaliar todas as populações $F_{2}$ é muito grande. Portanto, sempre que possível deve-se preferir utilizar a média dos genitores em detrimento da capacidade geral de combinação estimada em $F_{2}$.

\subsubsection{Capacidade preditiva da distância euclidiana}

A distância euclidiana não foi um bom preditor da variância genética das 14 populações formadas a partir do cruzamento entre linhagens adaptadas com não adaptadas (Tabela 71), apresentando correlações baixas e não significativas para a maioria das avaliações realizadas.

As correlações entre a distância euclidiana e as médias das populações foram significativas para todos os caracteres, à exceção de acamamento. $O$ valor das correlações foram relativamente altos, tanto para os coeficiente de Pearson quanto para o coeficiente de Spearman (Tabela 72). Isto indica que a distância euclidiana foi capaz de prever com relativa segurança a magnitude das médias e a classificação das populações quanto a este parâmetro.

As correlações entre a distância euclidiana e a proporção de progênies superiores também foram altas segundo os coeficientes de Pearson e Spearman (Tabela 73). Somente a proporção de progênies com acamamento acima da média das 493 progênies não apresentou correlações significativas com a distância euclidiana. 
Tabela 71. Coeficientes de correlação de Pearson (P) e Spearman (S) entre a distância euclidiana e a variância genética das 14 populações endogâmicas formadas pelo cruzamento entre linhagens adaptadas com não adaptadas.

\begin{tabular}{|c|c|c|c|c|c|c|c|c|c|c|c|c|}
\hline \multirow[b]{2}{*}{ Geração } & \multicolumn{2}{|c|}{$A C$} & \multicolumn{2}{|c|}{$\mathrm{AF}$} & \multicolumn{2}{|c|}{$A M$} & \multicolumn{2}{|c|}{ DF } & \multicolumn{2}{|c|}{$\overline{D M}$} & \multicolumn{2}{|c|}{ PG } \\
\hline & $P$ & $S$ & $P$ & $S$ & $P$ & $S$ & $P$ & $S$ & $P$ & $S$ & $P$ & $S$ \\
\hline$\overline{F_{2: 8}}$ & $-0,22$ & $-0,09$ & & & 0,00 & 0,19 & & & & & $-0,46$ & $-0,57^{\star}$ \\
\hline$F$ & 0,07 & 0,13 & $0,57^{\star}$ & $0,64^{*}$ & 0,08 & 0,31 & 0,19 & 0,28 & 0,04 & $-0,07$ & $-0,35$ & $-0,19$ \\
\hline$F_{2}$ & & & 0,01 & 0,05 & $-0,21$ & $-0,05$ & 0,33 & 0,26 & & $-0,29$ & $-0,26$ & $-0,30$ \\
\hline$F_{2:}$ & & & 0,29 & 0,33 & $-0,14$ & 0,02 & $-0,17$ & $-0,13$ & $-0,20$ & & $-0,55^{\star}$ & $-0,60^{*}$ \\
\hline Conjunta & $-0,42$ & $-0,43$ & 0,41 & 0,36 & $-0,07$ & 0,25 & 0,33 & 0,29 & $-0,10$ & $-0,30$ & $-0,38$ & $-0,46$ \\
\hline
\end{tabular}

AC - Acamamento; AF - Altura das plantas no florescimento; $A M$ - altura das plantas na maturação; DF dias para o florescimento; DM - dias para a maturação; PG - produção de grãos

Tabela 72. Coeficientes de correlação de Pearson (P) e Spearman (S) entre a distância euclidiana e as médias das 14 populações endogâmicas formadas pelo cruzamento entre linhagens adaptadas com não adaptadas.

\begin{tabular}{|c|c|c|c|c|c|c|c|c|c|c|c|c|}
\hline \multirow[b]{2}{*}{ Geração } & \multicolumn{2}{|c|}{$A C$} & \multicolumn{2}{|c|}{$\mathrm{AF}$} & \multicolumn{2}{|c|}{$A M$} & \multicolumn{2}{|c|}{ DF } & \multicolumn{2}{|c|}{$\overline{D M}$} & \multicolumn{2}{|c|}{$P G$} \\
\hline & $\mathrm{P}$ & $S$ & $P$ & $S$ & $\mathrm{P}$ & $S$ & $\mathrm{P}$ & $\mathrm{S}$ & $P$ & $S$ & $P$ & $S$ \\
\hline $\mathrm{F}_{2: 8}$ & 0,33 & 0,45 & & & $0,53^{\star}$ & $0,73^{\star}$ & & & & & $0,66^{\star \star}$ & $0,68^{*}$ \\
\hline$F_{2: 9}$ & 0,23 & 0,13 & $0,81^{\text {** }}$ & $0,67^{\star}$ & $0,61^{\star \star}$ & $0,81^{\star}$ & $0,84^{\star \star}$ & $0,67^{\star}$ & $0,55^{*}$ & $0,56^{*}$ & 0,51 & 0,35 \\
\hline$=2: 10$ & & & $0,73^{\star \star}$ & 0,7 & 0,49 & $0,67^{\star}$ & $0,84^{\star \star}$ & $0,78^{*}$ & & 0,49 & 0,51 & 0,42 \\
\hline 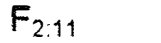 & & & 0,8 & 0 , & 0,5 & 0 & 0,6 & $0,70^{*}$ & 0,51 & & $0,77^{\star \star}$ & $0,69^{*}$ \\
\hline onjunta & 0,31 & 0,31 & $0,81^{\star \star}$ & $0,73^{\star}$ & $0,55^{\star}$ & $0,77^{\star}$ & $0,82^{\star \star}$ & $0,73^{\star}$ & $0,56^{\star}$ & $0,61^{*}$ & $0,67^{\star \star}$ & $0,56^{*}$ \\
\hline
\end{tabular}

AC - Acamamento; AF - Altura das plantas no florescimento; AM - altura das plantas na maturação; DF dias para o florescimento; DM - dias para a maturação; PG - produção de grãos

Tabela 73. Coeficientes de correlação de Pearson $(P)$ e Spearman $(S)$ entre a distância euclidiana e a proporção de progênies superiores das 14 populações endogâmicas formadas pelo cruzamento entre linhagens adaptadas com não adaptadas.

\begin{tabular}{|c|c|c|c|c|c|c|c|c|c|c|c|c|}
\hline \multirow[b]{2}{*}{ Geração } & \multicolumn{2}{|c|}{$A C$} & \multicolumn{2}{|c|}{$\mathrm{AF}$} & \multicolumn{2}{|c|}{ AM } & \multicolumn{2}{|c|}{$\mathrm{DF}$} & \multicolumn{2}{|c|}{$D M$} & \multicolumn{2}{|c|}{$P G$} \\
\hline & $P$ & $S$ & $P$ & $S$ & $P$ & $S$ & $P$ & $S$ & $P$ & $S$ & $P$ & $S$ \\
\hline $2: 8$ & 0,35 & 0,47 & & & $0,66^{\star}$ & $0,77^{\star}$ & & & & & $0,78^{\star}$ & 0,7 \\
\hline 9 & 0,49 & $0,56^{\star}$ & $0,82^{\star}$ & $0,67^{\star}$ & $0,68^{\star}$ & $0,83^{\star}$ & $0,83^{\star}$ & $0,67^{\star}$ & 0,49 & 0,42 & $0,56^{\star}$ & U, \\
\hline 10 & & & $0,82^{\star}$ & $0,70^{\star}$ & $0,53^{\star}$ & $0,64^{*}$ & $0,85^{\star}$ & $0,82^{\star}$ & & 0,41 & 0,40 & 0,29 \\
\hline 11 & & & $0,77^{\star}$ & $0,67^{\star}$ & $0,66^{*}$ & $0,78^{*}$ & $0,64^{\star}$ & $0,64^{*}$ & 0,38 & & $0,84^{*}$ & $0,67^{\star}$ \\
\hline onjunta & 0,47 & 0,53 & $0,80^{\star}$ & $0,72^{\star}$ & $0,76^{\star}$ & $0,86^{\star}$ & $0,82^{\star}$ & $0,69^{\star}$ & $0,55^{\star}$ & $0,63^{\star}$ & $0,81^{*}$ & $0,74^{\star}$ \\
\hline
\end{tabular}

AC - Acamamento; AF - Altura das plantas no florescimento; AM - altura das plantas na maturação; DF dias para o florescimento; DM - dias para a maturação; PG - produção de grãos 
Espera-se que quanto menor a distância entre o genitor não adaptado com o conjunto dos genitores adaptados, menores sejam as reduções indesejadas da produção. Isto porque os genitores não adaptados mais similares aos adaptados devem possuir um maior número de QTL's que contribuam para o aumento da produção. Mas o sentido da correlação da distância euclidiana com a produção de grãos mostra o contrário: quanto menor a distância euclidiana, menor foi a produção da população. Portanto, as predições com relação à produção de grãos somente seriam efetivas se o sentido da correlação fosse conhecido.

Da mesma maneira que a média dos genitores foi utilizada para determinar o sentido das correlações com as médias das 25 populações, ela também poderia ser utilizada para as populações formadas pelo cruzamento entre genitores adaptados e não adaptados. Portanto, seria possivel deduzir que a média das populações e a distância euclidiana se correlacionaram positivamente em cinco caracteres e que seriam independentes quanto ao acamamento.

Sabendo que a correlação com a produção média das populações deve ser positiva, poderiamos escolher a linhagem não adaptada mais distante das adaptadas para ser incorporada como genitora no programa de melhoramento. Analisando o dendrograma da Figura 1, verifica-se que a linhagem eleita seria a 8 . Portanto, como já foi mostrado, a escolha foi correta.

Os níveis de correlação verificados entre a distância euclidiana e a proporção de progênies superiores permitem inferir que as predições realizadas pela distância euclidiana são relativamente seguras para a produção de grãos, altura das plantas na maturação, altura das plantas florescimento e para o número de dias para o florescimento.

Comparando as capacidades preditivas, verifica-se que a distância euclidiana apresentaria melhor desempenho que a média dos genitores em relação no caráter produção de grãos e desempenho semelhante para a altura das plantas na maturação. Em relação à capacidade geral de combinação estimada em $F_{2}$ a distância euclidiana foi melhor para os caracteres altura das plantas na maturação e altura das plantas no florescimento.

Portanto, a distância euclidiana poderia ter sido utilizada para predizer o comportamento de alguns caracteres desde que o sentido das correlações com a média das populações fosse conhecido. 
4.12.4 Capacidade preditiva da distância euclidiana geral e especifica

A soma das distâncias euclidianas gerais $\left(D E G_{i}+D E G_{j}\right)$ apresentou coeficientes de correlação de Pearson e Spearman significativos com a média das populações e com a proporção de progênies superiores em cinco caracteres (Tabela 74). Apenas o acamamento apresentou comportamento independente. A distância euclidiana especifica não apresentou correlações com a variância genética e com proporção de progênies superiores (Tabela 75).

A intensidade das correlações com a proporção de progênies superiores foi expressivamente alterada pela partição da distância euclidiana. Os coeficientes de Pearson e de Spearman foram quase sempre maiores com a distância euclidiana geral. A única exceção foi verificada para a altura das plantas na maturação cujos coeficientes diminuíram após a partição. As alterações foram sempre expressivas, independente do coeficiente, mas tenderam a ser maiores com o coeficiente de Spearman. Portanto, a partição tendeu a aumentar a confiabilidade das predições da distância euclidiana.

Tabela 74. Coeficientes de correlação de Pearson e Spearman entre a soma das distância euclidianas gerais $\left(D E G_{i}+D E G_{j}\right)$ com as médias ajustadas das populações e com a proporção de progênies superiores, considerando as 14 populações formadas a partir do cruzamento entre uma linhagem adaptada com outra não adaptada.

\begin{tabular}{|c|c|c|c|c|c|c|c|c|c|c|c|c|}
\hline \multirow[b]{2}{*}{ Pearson } & \multicolumn{6}{|c|}{ DEG vs. média } & \multicolumn{6}{|c|}{ DEG vs. proporção } \\
\hline & $A M$ & PG & $\mathrm{DM}$ & $\mathrm{AF}$ & DF & $A C$ & AM & PG & DM & AF & DF & $A C$ \\
\hline $\mathrm{F}_{2: 8}$ & 0,53 & $0,73^{\star \star}$ & & & & 0,20 & 0,52 & $0,78^{\star \star}$ & & & & 0,22 \\
\hline$F_{2}: 9$ & 0,52 & 0,50 & $0,64^{\star}$ & $0,83^{\star \star}$ & $0,91^{\star \star}$ & 0,24 & 0,44 & $0,58^{\star}$ & $0,59^{\star}$ & $0,81^{\star \star}$ & $0,91^{\star \star}$ & 0,41 \\
\hline$F_{2 \cdot 10}$ & 0,45 & $0,62^{*}$ & & $0,81^{\star \star}$ & $0,87^{\star *}$ & & $0,54^{\star}$ & $0,59^{\star}$ & & $0,88^{\star \star}$ & $0,85^{\star \star}$ & \\
\hline$F_{2 \cdot 11}$ & 0,49 & $0,86^{\star \star}$ & $0,62^{*}$ & $0,86^{\star \star}$ & $0,77^{\star \star}$ & & $0,65^{\star}$ & $0,96^{\star \star}$ & $0,61^{*}$ & $0,87^{\star \star}$ & $0,79^{\star \star}$ & \\
\hline Conjunta & $0,61^{\star}$ & $0,74^{\star *}$ & $0,66^{*}$ & $0,86^{\star \star}$ & $0,88^{\star \star}$ & 0,26 & $0,61^{\star}$ & $0,87^{\star \star}$ & $0,70^{\star \star}$ & $0,86^{\star \star}$ & $0,88^{\star \star}$ & 0,38 \\
\hline Spearman & AM & PG & DM & $\mathrm{AF}$ & DF & $A C$ & AM & $\overline{P G}$ & $\overline{D M}$ & AF & DF & $\overline{A C}$ \\
\hline$F_{2: 8}$ & 0,53 & $0,71^{\star \star}$ & & & & 0,07 & $0,57^{\star}$ & $0,75^{\star \star}$ & & & & 0,13 \\
\hline$F_{2}: 9$ & 0,47 & 0,41 & $0,56^{\star}$ & $0,64^{\star}$ & $0,67^{\star \star}$ & 0,22 & 0,53 & $0,55^{\star}$ & 0,52 & $0,59^{*}$ & $0,69^{\star \star}$ & 0,30 \\
\hline$F_{2 \cdot 10}$ & 0,47 & $0,59^{\star}$ & & $0,67^{\star \star}$ & $0,69^{\star *}$ & & 0,38 & $0,58^{\star}$ & & $0,60^{\star}$ & $0,58^{\star}$ & \\
\hline$F_{2: 11}$ & 0,45 & $0,79^{\star \star}$ & 0,50 & $0,70^{\star \star}$ & $0,62^{\star}$ & & 0,49 & $0,92^{\star \star}$ & 0,48 & $0,62^{\star}$ & $0,74^{\star \star}$ & \\
\hline Conjunta & 0,49 & $0,67^{\star \star}$ & $0,56^{\star}$ & $0,63^{*}$ & $0,65^{\star}$ & 0,14 & $0,60^{\star}$ & $0,87^{\star \star}$ & $0,66^{\star \star}$ & $0,54^{\star}$ & $0,66^{\star}$ & 0,23 \\
\hline
\end{tabular}


Tabela 75. Coeficientes de correlação de Pearson e Spearman entre a distância euclidiana especifica com as variâncias genéticas das populações e a proporção de progênies superiores, considerando as 14 populações formadas a partir do cruzamento entre uma linhagem adaptada com outra não adaptada.

\begin{tabular}{c|cccccc|cccccc}
\hline & \multicolumn{7}{|c|}{ DEE vs. variância } & \multicolumn{5}{c}{ DEE vs. proporção } \\
\cline { 2 - 14 } Pearson & AM & PG & DM & AF & DF & AC & AM & PG & DM & AF & DF & AC \\
\hline$F_{2: 8}$ & 0,01 & $-0,15$ & & & & 0,04 & 0,14 & 0,05 & & & & 0,30 \\
$F_{2: 9}$ & 0,31 & 0,24 & $-0,06$ & $-0,31$ & $-0,31$ & $0,60^{\star}$ & 0,37 & $-0,02$ & $-0,18$ & 0,05 & $-0,13$ & 0,20 \\
$F_{2: 10}$ & 0,38 & $-0,54^{*}$ & & 0,02 & 0,16 & & 0,23 & $-0,37$ & & $-0,09$ & 0,05 & \\
$F_{2: 11}$ & 0,14 & $-0,13$ & $-0,33$ & $-0,01$ & 0,04 & & 0,29 & $-0,21$ & $-0,49$ & $-0,18$ & $-0,27$ \\
Conjunta & 0,31 & $-0,07$ & $-0,18$ & 0,16 & 0,08 & 0,22 & 0,28 & $-0,10$ & $-0,29$ & $-0,08$ & $-0,09$ & 0,21 \\
\hline Spearman & AM & PG & DM & AF & DF & AC & AM & PG & DM & AF & DF & AC \\
\hline$F_{2: 8}$ & 0,20 & $-0,32$ & & & & 0,02 & 0,24 & 0,23 & & & & 0,32 \\
$F_{2: 9}$ & $0,56^{*}$ & 0,36 & $-0,17$ & $-0,15$ & $-0,14$ & $0,62^{\star}$ & 0,32 & 0,06 & $-0,06$ & $-0,01$ & $-0,01$ & 0,15 \\
$F_{2: 10}$ & 0,42 & $-0,43$ & & $-0,04$ & $-0,05$ & & 0,16 & $-0,28$ & & 0,06 & 0,16 & \\
$F_{2: 11}$ & 0,31 & $-0,13$ & $-0,33$ & 0,07 & 0,18 & & 0,31 & $-0,20$ & $-0,29$ & $-0,01$ & $-0,11$ & \\
Conjunta & $0,57^{\star}$ & $-0,01$ & $-0,15$ & 0,35 & 0,30 & 0,20 & 0,25 & 0,07 & $-0,06$ & 0,06 & 0,02 & 0,21 \\
\hline
\end{tabular}

AC - Acamamento; AF - Altura das plantas no florescimento; $A M$ - altura das plantas na maturação; DF dias para o florescimento; DM - dias para a maturação; $P G$ - produção de grãos

Conforme propuseram os idealizadores da partição (Melchinger et al., 1990), o componente geral da distância genética indica se o genótipo possui alelos que ocorrem em alta ou baixa freqüência na conjunto avaliado. Valores positivos e altos indicam que o genótipo possui poucos alelos que ocorrem em alta freqüência e valores negativos e altos indicam que o genótipo possui muitos alelos que ocorrem em alta freqüência. O componente específico da distância genética indica se o cruzamento é mais ou menos heterozigoto, sendo mais heterozigoto quando o valor é mais positivo e menos heterozigoto quando é mais negativo.

Assim, a distância euclidiana geral contém informações a respeito de todos os locos acessados pela distância euclidiana. A informação a respeito dos locos que segregam apenas em um cruzamento específico foi transferida para a distância euclidiana específica. Sem a interferência da informação a respeito dos locos que segregam apenas em populações especificas, a distância euclidiana geral aumentou suas correlações com a média das populações e em conseqüência, com a proporção de progênies superiores.

Como observado na distância euclidiana, a distância euclidiana geral apresentou correlações positivas com a média das populações e com a proporção de 
progênies superiores. Novamente, seria necessário recorrer a média dos genitores para determinar o sentido das correlações entre a distância euclidiana geral e a média das populações. Uma vez determinado que a correlação entre a distância euclidiana geral e a média das populações no caráter produção de grãos das populações é positiva, seria novamente selecionada a linhagem 8 . Portanto, a seleção seria efetiva.

Conclui-se que a distância euclidiana geral poderia ser utilizada para realizar predições a respeito dos caracteres altura das plantas no florescimento, dias para o florescimento, dias na maturação e produção de grãos. Porém, deve-se primeiro conhecer o sentido das correlações com a média das populações para que erros não sejam cometidos.

\subsubsection{Capacidade preditiva da distância genética baseada em marcadores RAPD}

A distância genética baseada em marcadores RAPD não foi um bom preditor da variância genética das 14 populações (Tabela 76), apresentando correlações baixas e não significativas para a maioria dos caracteres. O melhor desempenho foi verificado para acamamento, contudo, o baixo valor da correlação não permitiria sua utilização para selecionar populações com maior variabilidade.

Com as médias das populações, a distância genética apresentou correlações significativas nos caracteres altura das plantas no florescimento, dias para florescimento, dias para o maturação e produção de grãos. Os valores dos coeficientes de correlação foram relativamente altos (Tabela 77).

A maioria das correlações verificadas foram negativas. Este resultado está de acordo com o esperado para o caráter produção de grãos, ou seja, quanto menor a distância entre uma linhagem não adaptada e o conjunto das linhagens adaptadas, maiores são as médias das populações. Com os demais caracteres não há um sentido natural para as correlações, pois existem genótipos não adaptados mais precoces e mais tardios, mais altos e mais baixos, etc. Portanto o conhecimento do comportamento dos genitores pode garantir que os resultados de uma seleção estejam de acordo com o esperado. 
As correlações entre a distância genética e a proporção de progênies superiores das populações não foram significativas apenas para acamamento (Tabela 78). Os valores dos coeficientes foram semelhantes aos obtidos com as médias ajustadas, concordando com os resultados que mostram que o potencial das populações está quase que exclusivamente associado às médias das populações.

Se uma seleção fosse realizada utilizando a distância genética, a linhagem 8 seria a escolhida. Como todos os demais parâmetros utilizados, a distância genética também foi capaz de identificar e selecionar a linhagem não adaptada mais adequada para ser utilizada como genitora. Porém, ao contrário da distância euclidiana, a predição com relação à produção das populações seria efetiva mesmo sem o auxílio da média dos genitores.

Tabela 76. Coeficientes de correlação de Pearson (P) e Spearman (S) entre a distância genética baseada em marcadores RAPD e a variância genética das 14 populações, formadas a partir do cruzamento entre linhagens adaptadas com não adaptadas.

\begin{tabular}{|c|c|c|c|c|c|c|c|c|c|c|c|c|}
\hline \multirow[b]{2}{*}{ Geração } & \multicolumn{2}{|c|}{$A C$} & \multicolumn{2}{|c|}{$\mathrm{AF}$} & \multicolumn{2}{|c|}{ AM } & \multicolumn{2}{|c|}{ DF } & \multicolumn{2}{|c|}{ DM } & \multicolumn{2}{|c|}{$P G$} \\
\hline & $P$ & S & $P$ & S & $P$ & $S$ & $P$ & $S$ & $P$ & $S$ & $P$ & $S$ \\
\hline $2: 8$ & 0,39 & $\overline{0,1}$ & & & 0,0 & 0 , & & & & & 6 & $\overline{0,30}$ \\
\hline 9 & 0,19 & 0,30 & $-0,64^{\star \star}$ & $-0,70^{*}$ & 0,37 & 0,2 & $-0,49$ & $-0,55^{\star}$ & $-0,40$ & $-0,20$ & 0,28 & 0,2 \\
\hline 10 & & & -0 & -0 & 0,42 & 0, & $-0,48$ & -0 & & & $-0,17$ & -0 , \\
\hline $2: 11$ & & & $-0,25$ & $-0,39$ & 0,22 & 0 & 0,15 & 0,04 & 0,09 & -0 & $-0,35$ & 0,39 \\
\hline oni & $0,57^{\star}$ & 0,65 & $-0,27$ & $-0,29$ & 0,34 & 0,19 & $-0,41$ & $-0,31$ & 0,01 & $-0,04$ & 0,24 & 0,25 \\
\hline
\end{tabular}

AC - Acamamento; AF - Altura das plantas no florescimento; AM - altura das plantas na maturação; $D F$ dias para o florescimento; DM - dias para a maturação; PG - produção de grãos

Tabela 77 Coeficientes de correlação de Pearson (P) e Spearman (S) entre a distância genética baseada em marcadores RAPD e a média das populações.

\begin{tabular}{|c|c|c|c|c|c|c|c|c|c|c|c|c|}
\hline \multirow[b]{2}{*}{ Geração } & \multicolumn{2}{|c|}{$A C$} & \multicolumn{2}{|c|}{$\mathrm{AF}$} & \multicolumn{2}{|c|}{$A M$} & \multicolumn{2}{|c|}{ DF } & \multicolumn{2}{|c|}{$D M$} & \multicolumn{2}{|c|}{$P G$} \\
\hline & $P$ & $S$ & $P$ & $S$ & $P$ & $S$ & $P$ & $S$ & $P$ & $S$ & $P$ & $S$ \\
\hline$\overline{F_{2: 8}}$ & 0,04 & 0,09 & & & $-0,50$ & $-0,53^{\star}$ & & & & & $-0,56^{\star}$ & $-0,58^{\star}$ \\
\hline $\mathrm{F}_{29}$ & 0,24 & 0,09 & $-0,85^{\star \star}$ & $-0,78^{\star}$ & $-0,52$ & $-0,50$ & $-0,82^{\star \star}$ & $-0,67^{\star}$ & $-0,79^{\star \star}$ & $-0,69^{\star}$ & $-0,40$ & $-0,31$ \\
\hline$F_{2: 10}$ & & & $-0,87^{\star \star}$ & $-0,83^{\star}$ & $-0,45$ & $-0,48$ & $-0,72^{\star \star}$ & $-0,70^{\star}$ & & & $-0,70^{\star \star}$ & $-0,64^{\star}$ \\
\hline$F_{2: 11}$ & & & $-0,72^{\star \star}$ & $-0,58^{\star}$ & $-0,43$ & $-0,40$ & $-0,68^{\star \star}$ & $-0,63^{*}$ & $-0,68^{\star \star}$ & $-0,57^{\star}$ & $-0,78^{\star \star}$ & $-0,73^{\star}$ \\
\hline Conjunta & 0,18 & 0,15 & $-0,86^{\star \star}$ & $-0,76^{\star}$ & $-0,48$ & $-0,50$ & $-0,77^{\star \star}$ & $-0,65^{\star}$ & $-0,76^{\star \star}$ & $-0,67^{\star}$ & $-0,65^{\star \star}$ & $-0,58^{\star}$ \\
\hline
\end{tabular}


Tabela 78. Coeficientes de correlação de Pearson (P) e Spearman (S) entre a distância genética baseada em marcadores RAPD e a proporção de progênies superiores das populações.

\begin{tabular}{|c|c|c|c|c|c|c|c|c|c|c|c|c|}
\hline \multirow[b]{2}{*}{ Geração } & \multicolumn{2}{|c|}{$\overline{A C}$} & \multicolumn{2}{|c|}{$\mathrm{AF}$} & \multicolumn{2}{|c|}{ AM } & \multicolumn{2}{|c|}{ DF } & \multicolumn{2}{|c|}{ DM } & \multicolumn{2}{|c|}{$\overline{P G}$} \\
\hline & $P$ & $S$ & $P$ & $S$ & $P$ & $S$ & $P$ & S & $P$ & S & $P$ & $S$ \\
\hline$F_{2: 8}$ & 0,05 & 0,06 & & & $-0,52$ & $-0,51$ & & & & & $-0,51$ & $-0,57^{\star}$ \\
\hline $\boldsymbol{F}_{2: 9}$ & $-0,36$ & $-0,32$ & $-0,84^{\star \star}$ & $-0,74^{*}$ & $-0,49$ & $-0,59 *$ & $-0,82^{\star \star}$ & $-0,68^{*}$ & $-0,41$ & $-0,43$ & $-0,42$ & $-0,48$ \\
\hline$F_{2: 10}$ & & & $-0,86^{\star \star}$ & $-0,66^{\star}$ & $-0,45$ & $-0,44$ & $-0,74^{\star *}$ & $-0,65^{\star}$ & & & $-0,63^{*}$ & $-0,63^{\star}$ \\
\hline$F_{2: 11}$ & & & $-0,72^{\star \star}$ & $-0,55^{\star}$ & $-0,41$ & $-0,40$ & $-0,70^{\star \star}$ & $-0,70^{*}$ & $-0,60^{*}$ & $-0,51$ & $-0,80$ * & $-0,81^{*}$ \\
\hline Conjunta & $-0,22$ & $-0,16$ & $-0,86^{\star \star}$ & $-0,66^{\star}$ & $-0,57^{\star}$ & $-0,62^{\star}$ & $-0,76^{\star \star}$ & $-0,60^{\star}$ & $-0,69^{\star \star}$ & $-0,70^{*}$ & $:-0,71^{* \star}$ & $-0,75^{\star}$ \\
\hline
\end{tabular}

As correlações entre a distância genética baseada em marcadores RAPD e a proporção de progênies superiores permitiria que as predições fossem confiáveis para quatro caracteres: altura das plantas na maturação, dias para o florescimento, dias para maturação e produção de grãos. As predições para a altura das plantas na maturação seriam pouco efetivas, pois a correlação verificada não foi alta o suficiente.

A distância genética seria capaz de realizar predições com confiabilidades no máximo iguais às que seriam realizadas pelos quatro métodos já descritos. Se for considerada apenas a precisão das predições, não haveria vantagem em utilizar a distância genética baseada em marcadores RAPD. Contudo, a distância genética obtida pela análise de marcadores é a única que independe da realização de experimentos no campo para ser obtida e a predição realizada para o caráter mais importante na cultura da soja - a produção de grãos - mostrou um bom nível de confiabilidade. Portanto ela poderia ter sido utilizada se fossem necessárias respostas mais rápidas. 
4.12.6 Capacidade preditiva da distância genética geral e da distância genética especifica

O acamamento médio das populações e a sua proporção de progênies superiores foram independentes da soma das distâncias genéticas gerais $\left(D G G_{i}+D G G_{j}\right)$. Para os demais caracteres, tanto a média das populações quanto a proporção de progênies superiores apresentaram correlações com a soma das distâncias genéticas gerais (Tabela 79). A distância genética específica não seria capaz de realizar predições a respeito da variância genética e da proporção de progênies superiores, pois nenhuma correlação foi observada (Tabela 80 ).

Comparando os coeficiente correlação das Tabelas 78 e 79, verifica-se que a partição da distância genética tendeu a aumentar as correlações com a proporção de progênies superiores. O maior aumento foi verificado com o caráter dias para a maturação, que cujo coeficiente de Pearson passou de 0,57 para 0,80 após a partição. Os aumentos foram quase sempre maiores com o coeficiente de Pearson do que com os de Spearman, mostrando que a melhora ocorreu de modo mais freqüente com a magnitude da proporção de progênies superiores do que com a classificação das populações.

Tabela 79. Coeficientes de correlação de Pearson e Spearman entre a soma da distância genética geral $\left(D G G_{i}+D G G_{j}\right)$ e a média das populações e a proporção de progênies superiores

\begin{tabular}{|c|c|c|c|c|c|c|c|c|c|c|c|c|}
\hline \multirow[b]{2}{*}{ Pearson } & \multicolumn{6}{|c|}{ DGG vs. média } & \multicolumn{6}{|c|}{ DGG vs. proporção } \\
\hline & $A M$ & PG & DM & $\mathrm{AF}$ & $\mathrm{DF}$ & $A C$ & $\overline{A M}$ & PG & $\overline{D M}$ & $\overline{A F}$ & DF & $A C$ \\
\hline$F_{2: 8}$ & $-0,64^{\star}$ & $-0,56^{\star}$ & & & & $-0,15$ & $-0,68^{\star \star}$ & $-0,54$ & & & & $-0,15$ \\
\hline$F_{29}$ & $-0,66^{\star}$ & $-0,38$ & $-0,81^{\star \star}$ & $-0,91^{\star \star}$ & $-0,91^{\star \star}$ & 0,01 & $-0,62^{\star}$ & $-0,50$ & $-0,53$ & $-0,90^{* *}$ & $-0,90^{\star \star}$ & $-0,58^{\star}$ \\
\hline$F_{2 \cdot 10}$ & $-0,61^{\star}$ & $-0,63^{*}$ & & $-0,93^{\star \star}$ & $-0,84^{\star \star}$ & & $-0,60^{\star}$ & $-0,57^{\star}$ & & $-0,95^{\star *}$ & $-0,89^{\star \star}$ & \\
\hline$F_{2: 11}$ & $-0,57^{\star}$ & $-0,79^{\star \star}$ & $-0,77^{\star \star}$ & $-0,81^{\star \star}$ & $-0,84^{\star *}$ & & $-0,57^{\star}$ & $-0,82^{\star \star}$ & * $-0,67^{\star \star}$ & $-0,87^{\star \star}$ & $-0,83^{\star \star}$ & \\
\hline Conjunta & $-0,63^{*}$ & $-0,63^{\star}$ & $-0,82^{\star \star}$ & $-0,93^{\star \star}$ & $-0,89^{\star \star}$ & $-0,06$ & $-0,70^{\star \star}$ & $-0,73^{\star \star}$ & $\star-0,80^{\star \star}$ & $-0,95^{\star \star}$ & $-0,88^{\star \star}$ & $-0,44$ \\
\hline Spearman & $A M$ & $P G$ & DM & $\overline{A F}$ & $\overline{D F}$ & $\overline{A C}$ & $\overline{A M}$ & PG & $\overline{D M}$ & $\overline{A F}$ & DF & $A C$ \\
\hline$F_{2: 8}$ & $-0,60^{*}$ & $-0,54^{\star}$ & & & & $-0,02$ & $-0,56^{\star}$ & $-0,42$ & & & & $-0,01$ \\
\hline$F_{2: 9}$ & $-0,63^{\star}$ & $-0,32$ & $-0,72^{\star}$ & $-0,81^{\star \star}$ & $-0,71^{\star *}$ & 0,06 & $-0,66^{\star}$ & $-0,61^{*}$ & $-0,54^{\star}$ & $-0,85^{\star \star}$ & $-0,70^{\star \star}$ & $-0,16$ \\
\hline$F_{2: 10}$ & $-0,52$ & $-0,68^{*}$ & & $-0,80^{\star *}$ & $-0,67^{\star \star}$ & & $-0,55^{\star}$ & $-0,63^{\star}$ & & $-0,75^{\star \star}$ & $-0,77^{\star \star}$ & \\
\hline$F_{2: 11}$ & $-0,49$ & $-0,74^{*}$ & $-0,62^{\star}$ & $-0,60^{\star}$ & $-0,75^{\star \star}$ & & 0,51 & $-0,66^{\star \star}$ & $\star-0,59^{\star}$ & $-0,70^{\star *}$ & $-0,74^{\star \star}$ & \\
\hline Coniunta & $-0,60^{\star}$ & $-0,53$ & $-0,70^{\star \star}$ & $-0,81^{\star \star}$ & $-0,74^{\star \star}$ & $-0,04$ & $-0,70^{\star \star}$ & $-0,69^{* \star}$ & ${ }^{\star}-0,76^{\star \star}$ & $-0,84^{\star \star}$ & $-0,69^{\star \star}$ & $-0,13$ \\
\hline
\end{tabular}
AC - Acamamento; AF - Altura das plantas no florescimento; AM - altura das plantes na maturação; DF dias para o florescimento; DM - dias para a maturação; PG - produção de grãos 
Tabela 80. Coeficientes de correlação de Pearson e Spearman entre a distância genética especifica e a variância genética das populações e a proporção de progênies superiores.

\begin{tabular}{|c|c|c|c|c|c|c|c|c|c|c|c|c|}
\hline \multirow[b]{2}{*}{ Pearson } & \multicolumn{6}{|c|}{ DGE vs. média } & \multicolumn{6}{|c|}{ DGE vs. proporção } \\
\hline & $\overline{A M}$ & $P G$ & $\overline{D M}$ & $\mathrm{AF}$ & $\mathrm{DF}$ & $\overline{A C}$ & $\overline{A M}$ & $\overline{P G}$ & DM & $\mathrm{AF}$ & DF & $A C$ \\
\hline$\overline{F_{2: 8}}$ & $-0,02$ & $-0,23$ & & & & 0,03 & 0,20 & $-0,11$ & & & & 0,43 \\
\hline $\mathrm{F}_{2: 9}$ & 0,26 & $-0,17$ & $-0,45$ & 0,26 & $-0,02$ & 0,23 & 0,13 & $-0,07$ & 0,23 & $-0,08$ & $-0,03$ & 0,42 \\
\hline$F_{2: 10}$ & 0,23 & $-0,42$ & & $-0,05$ & $-0,33$ & & 0,19 & $-0,28$ & & $-0,02$ & 0,18 & \\
\hline$F_{2: 11}$ & 0,41 & $-0,39$ & $-0,33$ & $-0,08$ & $-0,30$ & & 0,24 & $-0,16$ & 0,05 & 0,15 & 0,15 & \\
\hline Conjunta & 0,21 & $-0,21$ & $-0,29$ & $-0,10$ & $-0,23$ & 0,01 & 0,13 & $-0,15$ & 0,12 & 0,01 & 0,10 & 0,43 \\
\hline Spearman & $\overline{A M}$ & $\overline{P G}$ & $\overline{D M}$ & $\overline{\mathrm{AF}}$ & $\overline{D F}$ & $\overline{A C}$ & $\overline{A M}$ & $\overline{P G}$ & $\overline{D M}$ & $\overline{\mathrm{AF}}$ & $\overline{D F}$ & $\overline{A C}$ \\
\hline$\overline{F_{2: 8}}$ & $-0,01$ & $-0,30$ & & & & $-0,07$ & 0,22 & $-0,07$ & & & & 0,39 \\
\hline$F_{2: 9}$ & 0,24 & $-0,20$ & $-0,50$ & 0,24 & $-0,07$ & 0,23 & 0,09 & 0,17 & 0,40 & 0,15 & 0,10 & 0,46 \\
\hline$F_{2: 10}$ & 0,23 & $-0,18$ & & $-0,06$ & $-0,32$ & & 0,15 & $-0,15$ & & 0,24 & 0,39 & \\
\hline$F_{2: 11}$ & 0,34 & $-0,42$ & $-0,52$ & $-0,04$ & $-0,50$ & & 0,28 & $-0,20$ & 0,29 & 0,30 & 0,24 & \\
\hline Conjunta & 0,08 & $-0,24$ & $-0,30$ & $-0,01$ & $-0,24$ & $-0,10$ & 0,17 & $-0,05$ & 0,17 & 0,36 & 0,35 & 0,44 \\
\hline
\end{tabular}

AC - Acamamento; AF - Altura das plantas no florescimento; AM - altura das plantas na maturação; DF dias para o florescimento; $D M$ - dias para a maturação; PG - produção de grãos

As predições realizadas pela distância genética geral a respeito da altura das plantas no florescimento e do número de dias para a maturação seriam as mais confiáveis entre todos os métodos estudados. Porém, as predições a respeito da altura das plantas na maturação e da produção de grão seriam iguais às obtidas pelos métodos que apresentaram menor confiabilidade de predição nestes caracteres.

Conclui-se que a distância genética geral seria capaz de realizar predições a respeito dos caracteres altura das plantas no florescimento, altura das plantas na maturação, dias para o florescimento, dias para a maturação e produção de grãos.

4.13 Considerações sobre as predições realizadas a respeito do genitor não adaptado mais adequado

Todos os métodos testados foram capazes de identificar que a linhagem 8 foi o melhor genitor não adaptado. Porém, a confiabilidade das predições não foram iguais. As maiores confiabilidades nas predições para a produção foram obtidas pela capacidade geral de combinação estimada em $F_{2}$, seguida pela distância euclidiana geral. As predições realizadas pelos demais métodos foram menos confiáveis, mas 
seriam suficientes para realizar seleções em conjuntos de genitores não adaptados semelhantes aos utilizados neste estudo.

Embora as maiores correlações com proporção de progênies superiores do caráter produção de grãos tenham sido obtidas pela capacidade geral de combinação estimada em $F_{2}$, este método não é o mais recomendado para determinar qual a melhor linhagem não adaptada. A quantidade de trabalho envolvida com a obtenção e análise das populações $F_{2}$ é muito grande. Além disto, o método não oferece agilidade suficiente para os casos que demandem respostas rápidas, como quando uma nova doença foi introduzida.

A média dos genitores apresentou bom desempenho na maioria dos caracteres estudados. Sua pior performance foi obtida no caráter produção de grãos. Conforme já descrito, uma forte interação dos genótipos com o ambiente nos experimentos realizados para avaliar os genitores pode ser a responsável pela menor capacidade de predição deste caráter. Contudo, mesmo utilizando as médias dos genitores no ano em que as correlações foram maiores, os coeficientes não foram tão grandes quantos os verificados para os demais caracteres.

Dois fatores podem ter contribuido para a menor capacidade preditiva da média dos genitores neste caráter. O primeiro seria o mascaramento dos efeitos aditivos presentes nas linhagens não adaptadas devido à forte ação do ambiente e da interação genótipos $x$ ambientes na produção de grãos. Para contornar este problema as linhagens poderiam ser avaliadas em maior número de locais e anos e/ou poderiam ser incluidas testemunhas de comportamento conhecido (Triller \& Toldedo, 1996). segundo diz respeito a presença de efeitos epistáticos aditivos fortes nas populações formadas a partir do cruzamento entre genitores adaptados e não adaptados. Efeitos epistáticos foram verificados por Thorne \& Fehr (1970) e sua importância foi suficiente para impedir que a média das populações fossem preditas pela médias dos genitores.

Quanto a distância euclidiana e a distância euclidiana geral, as correlações positivas com a proporção de progênies superiores mostram que é necessário estar atento. Uma seleção só seria efetiva se fosse realizada contra o genótipo mais similar. Este critério não é o usual, pois espera-se que quanto maior a similaridade entre os materiais menores sejam as alterações indesejadas da média (Abdelnoor et al., 1995). Portanto, seria necessário determinar o sentido da correlação antes de realizar uma seleção entre os genitores não adaptados, podendo utilizar para este fim a média dos 
genitores. Como estas medidas de diversidade foram calculadas utilizando a média dos genitores, utilizá-las novamente não representa nenhum esforço adicional.

Com relação a distância genética baseada em marcadores RAPD, a predição da proporção de progênies superiores do caráter produção de grãos apresentou confiabilidade suficiente para identificar a melhor linhagem, mas outros métodos seriam mais confiáveis.

Segundo os coeficientes de Pearson, a partição das distâncias euclidiana e genética resultou em maiores correlações com a proporção de progênies superiores. A única redução foi observada entre a altura das plantas na maturação e a distância euclidiana. Os aumentos não foram iguais entre os caracteres e nenhuma evidência experimental e nenhuma discussão na literatura foram encontradas para justificar esta atuação diferencial. Resultados semelhantes já haviam sido obtidos quando as 25 populações foram consideradas, mas os aumentos verificados com as 14 populações foram mais expressivos. Em virtude destes resultados, pode-se concluir que a partição melhorou a capacidade das duas distâncias em realizar predições a respeito da magnitude da proporção de progênies superiores. Embora tenha sido empregado um conjunto fixo de populações, é provável que a partição das distâncias genéticas seja recomendada em situações semelhantes às encontradas neste trabalho.

As linhagens não adaptadas não são utilizadas freqüentemente em programas de melhoramento. Elas estão presentes em bancos de germoplasma e muitas vezes não estão bem caracterizadas ou a caracterização foi realizada em locais com ambiente diferente ao encontrado na região que o programa de melhoramento se destina. Quando isto ocorre, a escolha com base na distância euclidiana e na média dos genitores requer que a avaliação dos candidatos a genitor recorrente seja realizada em, pelo menos, um ano agricola. Mas, o ano agrícola coincide com o único periodo em que é possivel realizar cruzamentos em soja. Portanto, entre a predição e a realização dos cruzamentos terá se passado pelo menos um ano.

Nem sempre é possivel ou se deseja esperar todo este tempo para iniciar o programa. Nestes casos, a distância genética baseada em marcadores RAPD ou a distância genética geral são os métodos preditivos mais recomendados, pois podem ser estimados rapidamente e independente da época do ano. 


\section{CONCLUSÕES}

As generalizações realizadas a seguir não devem ser válidas para populações formadas exclusivamente a partir do cruzamento entre genitores adaptados. Porém, para conjuntos de populações semelhantes aos utilizados neste estudo, ou seja, formados por genitores adaptados e não adaptados, é provável que as conclusões possam ser úteis para orientar novos estudos.

Em função dos resultados obtidos e das discussões realizadas, conclui-se que:

- A capacidade geral de combinação estimada em $F_{2}$ e a média dos genitores foram as melhores técnicas de predição.

- A distância genética obtida pela análise de marcadores RAPD pode ser utilizada para predizer o potencial das populações endogâmicas e para selecionar a melhor linhagem genitora não adaptada de soja com relação a alguns caracteres de soja, incluindo produção de grãos.

- A utilização da distância genética geral, obtida pela partição da distância genética baseada em marcadores RAPD, pode ser empregada para aumentar a confiabilidade das predições.

- Em parte dos caracteres, incluindo produção de grãos, a confiabilidade das predições realizada pelas medidas de diversidade genética baseadas em marcadores RAPD deve ser semelhante às obtidas pelas melhores técnicas de predição testadas. 
- A distância euclidiana obtida pela análise da média dos genitores não é um bom método preditivo para avaliar o comportamento das populações, mas possui bom desempenho para escolher o melhor genitor não adaptado em parte dos caracteres avaliados. 


\section{REFERÊNCIAS BIBLIOGRÁFICAS}

ABDELNOOR, R.V.; BARROS, E.G.; MOREIRA, M.A. Determination of genetic diversity within Brazilian soybean germplams using random amplified polymorphic DNA techniques and comparative analysis with pedigree data. Revista Brasileira de Genética, v.18, n.2, p.265-273, 1995.

AJMONE-MARSAN, P.; CASTIGLIONE, P.; FUSARI, F.; KUIPER, M.; MOTTO, M. Genetic diversity and its relationship to hybrid performance in maize as revealed by RFLP and AFLP markers. Theoretical and Applied Genetics, v.96, n.2, p.219227, 1998.

ALI, M.; COPELAND, L.O.; ELIAS, S.G.; KELLY, J.D. Relationship between genetic distance and heterosis for yield and morphological traits in winter canola (Brassica napus L.). Theoretical and Applied Genetics, v.91, p.118-121, 1995.

ANTUNES, I.F.; VELLO, N.A.; TEIXEIRA, M.G.; SILVEIRA, E.P. EMYGDIO, B.M.; ZONTA, E.P. Predição da produtividade de grãos em populações $F_{2}$ de feijoeiro a partir da média parental. Ciência Rural, v.28, n.3, p.357-360, 1998.

ARUNACHALAM, V.; BANDYOPADHYAY, A.; NIGAM, S.N.; GIBBONS, R.W. Heterosis in relation to genetic divergence and specific combining ability in groundnut (Arachis hypogea L.). Euphytica, v.33, n.1, p.33-39, 1984.

BARBIN, D. Componentes de variância: teoria e aplicações. Piracicaba: FEALQ, 1993. 120p.

BARBOSA-NETO, , J.F.; SORRELLS, M.E.; CISAR, G. Prediction of heterosis in wheat using coefficient of parentage and RFLP-based estimates of genetic relationship. Genome, v.39, p.1142-1149, 1996. 
BERNARDO, R. Relationship between single-cross performance and molecular markers heterozigosity. Theoretical and Applied Genetics, v.83, p.628-634, 1992.

BHATADE, S.S.; SINGH, C.B.; TIWARI, A.S. Diallel analysis of yield and its components in soybean. Indian Journal of Agriculture Science, v.47, p.322-324, 1977.

BOPPENMAIER, J.; MELCHINGER, A.E.; SEITZ, G.; GEIGER, H.H.; HERRMANN, R.G. Genetic diversity for RFLP in European maize inbreds. III. Performance of crosses. Plant Breeding, v.111, p.217-226, 1993.

BURKHAMER, R.L.; LANNING, S.P.; MARTENS, R.J.; MARTIN, J.M.; TALBERT, L.E. Predicting progeny variance from parental divergence in hard red spring wheat. Crop Science, v. 38, p.243-248, 1998.

BURSTIN, J.; CHARCOSSET, A.; BARRIĖRE, Y.; HÉBERT, Y.; VIENE, D.; DAMERVAL, $C$. Molecular markers and protein quantities as genetic descriptors in maize. II. Prediction of performance of hybrids for forage traits. Plant Breeding, v.114, p.427-433, 1995.

BUSH, R.H.; JANKE, J.C.; FROHBERG, R.C. Evaluation of crosses among high and low yielding parents of spring wheat (Triticum aestivum L.) and bulk prediction of line performance. Crop Science, v.14, n.1, p.47-50, 1974.

CERNA, F.J.; CIANZIO, S.R.; RAFALSKI, A.; TIGERY, S.; DYER, D. Relationship between seed yield heterosis and molecular marker heterozygosity in soybean. Theoretical and Applied Genetics, v.95, p.460-467, 1997.

CHARCOSSET, A,; ESSIOUX, L. The effect of population structure on the relationship between heterosis and heterozygosity at marker loci. Theoretical and Applied Genetics, v.89, p.336-343, 1994.

CHOO, T.M.; KOTECHA, A.; REINGERGS, E.; SONG, L.S.P.; FEJER, S.O. Diallel analysis of grain yield in barley using double-haploid lines. Plant Breeding, v.97, n.2, p.129-137, 1986.

COWEN, N.M.; FREY, K. J. Relationships between genealogical distance and breeding behaviour in oats (Avena sativa L.) Euphytica, v.36, p.413-424, 1987a. 
COWEN, N.M.; FREY, K. J. Relationships between three measures of genetic distance and breeding behaviour in oats (Avena sativa L.) Genome, v.29, p.97$106,1987 \mathrm{~b}$.

COX, T.S.; KIANG, Y.T.; GORMAN, M.B.; RODGERS, D.M. Relationship between coefficient of parentage and genetic similarity indices in the soybean. Crop Science, v. 36, p.413-424, 1985.

COX, T.S.; MURPHY, J.P. The effect of parental divergence on $F_{2}$ heterosis in winter wheat crosses. Theoretical and Applied Genetics, v.79, p.241-250, 1990.

CRUZ, C.D.; REGAZZI, A.J. Modelos biométricos aplicados ao melhoramento genético. Viçosa, UFV, 1997. 390p.

CRUZ, C.D.; SEDIYAMA, C.S.; SEDIYAMA, T. Capacidade combinatória e efeitos reciprocos de alguns caracteres em soja. Revista Ceres, v.34, p.432-439, 1987.

CRUZ, R.P.; MILACH, S.C.K. Análise RAPD. In: Milach, S.C.K. (Ed.) Marcadores moleculares em plantas. Porto Alegre: Sandra C.K. Milach, 1998, 140p.

DHILLON, B.S.; BOPPENMAIER, W.G.; POLLMER, W.G.; HERRMANN, A.E.; MELCHINGER, A.E. Relationship of restriction fragment length polymorphism among European maize inbreds with ear dry matter yield of their hybrids. Maydica, v.38, p.245-248, 1993.

DUARTE, J.M.; SANTOS, J.B.; MELO, L.C. Genetic divergence among common bean cultivars from different races based on RAPD markers. Genetics and Molecular Biology, v.22, n.3, p.419-426, 1999.

FABRIZIUS, M.A.; BUSCH, R.H.; KHAN, K.; HUCKLE, L. Genetic diversity and heterosis of spring wheat crosses. Crop Science, v.38, p.1108-1112, 1998.

FALCONER, D.S.; MACKAY, T.F.C. Introduction to quantitative genetics. Essex: Longman, 1996. 464p.

FEHR, W.R. Principles of cultivar development. New York: Macmillan Publishing Company, 1987. 536p.

FREIRE FILHO, F.R. Análise genética de um dialelo entre genótipos precoces de soja (Glycine max (L.) Merrill). Piracicaba, 1988. 224p. Tese (Doutorado) - Escola 
Superior de Agricultura "Luiz de Queiroz" , Universidade de São Paulo.

GAYLOR, D.W.; LUCAS, H. L.; ANDERSON, R.L. Calculation of expected mean squares by abbreviated doolitle and square root methods. Biometrics, v.26, n.4. p. 641-655, 1970.

GHADERI, A.; ADAMS, M.W.; NASSIB, A.M. Relationship between genetic distance and heterosis for yield and morphological traits in dry edible bean and faba bean. Crop Science, v.24, n.1, p.37-42, 1984.

GIECO, J.O. Interações genótipos $x$ ambientes e implicações para o melhoramento da soja. Piracicaba, 1997. 98p. Dissertação (M.S.) - Escola Superior de Agricultura "Luiz de Queiroz", Universidade de São Paulo.

GIZLICE, Z.; CARTER, T.E.; BURTON, J.W. Genetic diversity in North American soybean: 1. Multivariate analysis of founding stock and relation to coefficient of parentage. Crop Science, v.33, p.620-626, 1993a.

GIZLICE, Z.; CARTER, T.E.; BURTON, J.W. Genetic diversity in North American soybean: II. Prediction of heterosis in $F_{2}$ populations of southern founding stock using genetic similarity measures. Crop Science, v.33, p.620-626, $1993 \mathrm{~b}$.

GRIFFING, B. Concept of general and specific combining ability in relation to diallel crossing systems. Australian Journal of Biological Sciences, v.9, p.463-493, 1956.

GUMBER, R.K.; SCHILL, B.; LINK, W.; KITTLITZ, E.V.; MELCHINGER, A.E. Mean, genetic variance, and usefulness of selfing progenies from inter- and inter pool crosses in faba beans (Vicia faba L.) and their prediction from parental parameters. Theoretical and Applied Genetics, v.98, n.3-4, p.569-580, 1999.

HAMBLIN, J.; EVANS, A.M. The estimation of cross yield using early generation and parental yield in dry beans (Phaseolus vulgaris L.). Euphytica, v.25, p.515-520, 1976.

HAMBLIN, J.; ROSIELLE, A.A. Effect of intergenotypic competion on genetic parameters estimation. Crop Science, v.18, p.51-54, 1978.

HELMS, T.; ORF, J.; MCCLEAN, P. Genetic variance, coefficient of parentage, and 
genetic distance of six soybean populations. Theoretical and Applied Genetics, v.94, n.1, p.20-26, 1997.

HIROMOTO, D.M.; VELLO, N. A. The genetic base of Brazilian soybean (Glycine max (L.) Merrill) cultivars. Revista Brasileira de Genética, v.9, p.295-306, 1986.

ININDA, J.; FEHR, W.R.; SILVIA, R.; SCHNEBLY, S.R. Genetic gain in soybean populations with different percentages of plant introduction parentage. Crop Science, v.36, p.1470-1472, 1996.

JINKS, J.L.; POONI, H.S. Predicting the properties of recombinant inbred lines derived by single seed descent. Heredity, v.38, n.2, p.253-66, 1976.

JINKS, J.L.; POONI, H.S. Comparing predictions of mean performance and environmental sensivity of recombinant inbred lines based upon $F_{3}$ and triple testcross families. Heredity, v. 45, n.3, p. 305-12, 1980.

KEARSEY, M.J.; POONI, H.S. The genetical analysis of quantitative traits. London: Chapman \& Hall, 1996. 380p.

KHAN, I.A.; IMTIAZ, S.; MALIK, A. Selection of diverse parents of chickpea (Cicer arietinum $L$.) by multivariate analysis and the degree of heterosis of their $F_{1}$ hybrids. Theoretical and Applied Genetics, v.51, p.227-233, 1991.

KISHA, T.J., SNELLER, C.H.; DIERS, B.W. Relationship between genetic distance among parents and genetic variance in populations of soybean. Crop Science, V. 37, p.1317-1325, 1997.

LEFORT-BUSON, M.; GUILLOT-LEMOINE, B; DATEE, Y. Heterosis and genetic distance in rapeseed (Brassica napus L.). Use of different indicators of genetic divergence in a $7 \times 7$ diallel. Agronomie, v. 6, n.9, p.839-844, 1986.

LEFORT-BUSON, M.; DATEE, Y.; GUILLOT-LEMOINE, B. Heterosis and genetic distance in rapessed (Brassica napus L.): use of kinship coefficient. Genome, v. 26, n.1, p.11-18, 1987.

LIU, Z.Q.; PEI, Y.; PU; Z.J. Relationship between hybrid performance and genetic diversity based on RAPD markers in wheat, Triticum aestivum L.. Plant Breeding, v. 119, p.119-123, 1999. 
MACCLUER, J.W.; BOYCE, A.J.; DYBE, B.; WEITKAMP, L.R.; PFENNING, D.W.;

PARSONS, C.J. Inbreeding and pedigree structure in standard bred horses. Journal of Heredity, v.74, p.394-399, 1983.

MALÉCOT, G. Les mathématiques de l'héré dité. Paris: Masson et Cie, 1948.

MALUF, W.R.; FERREIRA, P.E.; MIRANDA, J.E.C. Genetic divergence in tomatoes and its relationships with heterosis for yield in $F_{1}$ hybrids. Revista Brasileira de Genética, v.6, n.3, p.453-460, 1983.

MANJARREZ-SANDOVAL, P. CARTER Jr, T.E.; D.M. WEBB; BURTON, J.W. Heterosis in soybean and its prediction by genetic similarity measures. Crop Science, v.37, p.1443-1452, $1997 a$.

MANJARREZ-SANDOVAL, P.; CARTER Jr, T.E.; D.M. WEBB; BURTON, J.W. RFLP Genetic similarity and coefficient of parentage as genetic variance predictors for soybean yield. Crop Science, v.37, p.698-703, 1997b.

MELCHINGER, A.E.; LEE, M.; LAMKEY, K.R.; HALLAUER, A.R.; WOODMAN, W.L. Genetic diversity for restriction fragment length polymorphisms and heterosis for two diallel sets of maize inbreds. Theoretical and Applied Genetics, v.80, p.488496, 1990 a.

MELCHINGER, A.E.; LEE, M.; LAMKEY, K.R.; WOODMAN, W.L. Genetic diversity for restriction fragment length polymorphisms: relation to estimated genetic effects in maize inbreds. Crop Science, v.30, p.1033-1040, 1990b.

MELCHINGER, A.E.; BOPPENMAIER, J. DHILLON, B.S.; POLLMER, W.G.; HERRMANN, R.G. Genetic diversity for RFLPs in European maize inbreds: II. Relation to performance of hybrids within versus heterotic groups for forage traits. . Theoretical and Applied Genetics, v.84, p.672-681, 1992.

MESSMER, M.M.; MELCHINGER, A.E.; HERRMANN, R.G.; BOPPENMAIER, J. Relationships among early European maize inbreds: II. Comparison of pedigree and RFLP data. Crop Science, v.33, p.944-950, 1993.

MIRANDA, J.E.C.; CRUZ, C.D.; COSTA, C.P. Predição do comportamento de híbridos de pimentão (Capsicum annuum L.) pela divergência genética dos progenitores. Revista Brasileira de Genética, v.11, p.929-937, 1988. 
MOSER, H.; LEE, M. RFLP variation and genealogical distance, multivariate distance, heterosis, and genetic variance in oats. Theoretical and Applied Genetics, v.87, n.947-956, 1994.

NASS, L.L. Potencialidade de genótipos de soja (Glycine max (L.) Merrill) para cultivo de inverno através de cruzamentos dialélicos. Piracicaba, 1989. 112p. Dissertação (M.S.) - Escola Superior de Agricultura "Luiz de Queiroz", Universidade de São Paulo.

OLIVEIRA, V.R.; SCAPIM, C.A.; CASALI, V.W.D. Diversidade genética e eficiência de predição do comportamento de híbridos de pimentão (Capsicum annuum L.). Acta Scientiarum, v.20, n.3, p.263-267, 1998.

PACOVA, B.E.V. Análise genética de progênies segregantes de soja apropriada para o consumo humano. Piracicaba, 1992. 217p. Tese (Doutorado) - Escola Superior de Agricultura "Luiz de Queiroz" , Universidade de São Paulo.

PALUDZYSZYN FILHO, E. Análise do potencial genético de cultivares de soja (Glycine max (L.) Merrill) através de cruzamentos dialélicos. Piracicaba, 1982. 94p. Dissertação - Escola Superior de Agricultura "Luiz de Queiroz" , Universidade de São Paulo.

PRADO, L.C. Estratégias de seleção em soja com base na avaliação em vários anos. Piracicaba, 1999. 92p. Tese (Doutorado) - Escola Superior de Agricultura "Luiz de Queiroz", Universidade de São Paulo.

PAZ, M.M.; VEILLEUX, R.E. Genetic diversity based on randomly amplified polymorphic DNA (RAPD) and its relationships with the performance of diploid potato hybrids. Journal of the American Society for Horticultural Science, v. 122 , n.6, p.740-747, 1997.

PICARD, B.; BRANLARD, G.; OURY, F.X.; BÉRARD, P.; ROUSSET, M. Étude de la diversité génétique du blé tendre. II. Aplication à la prédiction de l'hétérosis. Agronomie, v.12, p.683-690, 1992.

PIMENTEL, A.M. Cruzamentos dialélicos em soja com ênfase em teor de proteína e produção de grãos. Piracicaba, 1991. 150p. Dissertação (M.S.) - Escola Superior de Agricultura "Luiz de Queiroz" , Universidade de São Paulo. 
PRABHU, R.R.; WEBB, D.; JESSEN, H.; LUK, S.; SMITH, S.; GRESSHOFF, P.M. Genetic relatedness among soybean genotypes using DNA amplification fingerprinting (DAF), RFLP, and pedigree. Crop Science, v.37, p.1590-1595, 1997.

PULCINELLI, C.E. Avaliação de cruzamentos dialélicos de soja em gerações avançadas de endogamia. Piracicaba, 1997. 167p. Tese (Doutorado) - Escola Superior de Agricultura "Luiz de Queiroz" , Universidade de São Paulo.

RAMALHO, M.A.P.; SANTOS, J.B.; PEREIRA FILHO, I. Choice os parents for dry bean (Phaseolus vulgaris L.) breeding: I. Interaction of mean components by generation and by location. Revista Brasileira de Genética, v.11, n.2, p.391-400, 1988.

RAMALHO, M.A.P.; VENCOVSKY, R. Estimação dos componentes da variância genética em plantas autógamas. Ciência e Prática, v.2, n.117-140, 1978.

ROGERS, S.O.; BENDICH, A.J.. Extraction of DNA from milligram amounts of fresh, herbarium, and mummified plant tissues. Plant Molecular Biology, v.5, p. 69-76, 1985.

SABBOUGH, M.Y. Genetics studies of protein and oil in soybean [Glycine max (L.) Merrill]. In: Dissertation Abstract International B. Sciences and Engineering, v.47, p.3175, 1987.

SAINT MARTIN; S.K. ASLAM, M. Performance of progeny adapted and plant introduction soybean lines. Crop Science, v.26, p. 753-756, 1986.

SANT, V.J.; PATANKAR, A.G.; SARODE, N.D.; MHASE, L.B.; SAINANI, M.N.; DESHMUKH, R.B.; RANJEKAR, P.K.; GUPTA, V.S. Potential of DNA markers in detecting divergence and in analyzing heterosis in Indian elite chickpea cultivars. Theoretical and Applied Genetics, v. 98, p.1217-1225, 1999.

SARAWAT, P.; STODDARD, F.L.; MARSHALL, D.R. Derivation of superior $F_{5}$ lines from heterotic hybrids in pea. Euphytica, n.73, p.265-272, 1994a.

SARAWAT, P.; STODDARD, F.L.; MARSHALL, D.R. Genetic distance and its association with heterosis in peas. Euphytica, n.73, p.255-264, 1994b. 
SCHOENER, C.S.; FEHR, W.R. Utilization of plant introductions in soybean breeding populations. Crop Science, v.19, p.185-188, 1979.

SCOTT, A.J.; KNOTT, M. A cluster analysis method for grouping means in the analysis of variance. Biometrics, v.30, p.507-512, 1974.

SCOTT, R.A.; KEPHART, K.D. Selection for yield, protein, and oil in soybean crosses between adapted and introduced parents. Field crops research, v.49, n.2-3, p.177-185, 1997.

SEARLE, S.R. Linear models for unbalance data. New York: John Wiley \& Sons,. 539p. (1987)

SILVA, H.D. Análise de experimentos em látice quadrado ("square lattice") com ênfase em componentes de variância e aplicações no melhoramento genético vegetal. Viçosa, 1997. 139p. Dissertação (M.S.) - Universidade Federal de Viçosa.

SNEATH, P.H.A.; SOKAL, R.R. Numerical taxonomy. San Francisco: W.H. Freeman and Company, 1973. 573p.

SOUZA, E.; SORRELS, M.E. Prediction of progeny variation in oat from parental genetic relationships. Theoretical and Applied Genetics, v. 82, p.233-241, 1991.

SPEHAR, C.R. Diallel analysis for mineral element absortion in tropical adapted soybeans Glycine $\max (\mathrm{L}$.) Merrill. Theoretical and Applied Genetics, v. 90, n.5, p.707-713, 1995.

STUTHMAN, D.D.; STUCHER, R.E. Combining ability analysis of near homozygous lines derived from a 12-parent diallel cross in oats. Crop Science, v.15, n.6, p.800-803, 1975.

THORNE, J.C.; FEHR, W.R. Ecotic germplasm for yield improvement in 2-way and 3way soybean crosses. Crop Science, v.10, p.677-678, 1970.

TIVANG, J.G.; NIENHUIS, J.; SMITH, O.S. Estimation of sampling variance of molecular marker data using bootstrap procedure. Theoretical and Applied Genetics, v. 89, p. 259-64, 1994.

TOLEDO, J.F.F. Predicting the inbreeding and the outcrossing potential of soybean (Glycine $\max ($ L.) MERRIL) varieties. Revista Brasileira de Genética, v. 10, 
p.543-558, 1987.

TRILLER, C.; TOLEDO, J.F.F. Using the $F_{3}$ generation for predicting the breeding potential of soybean crosses. Revista Brasileira de Genética, v.19, n.2, p.289294, 1996.

VANTOAI, T.T.; PENG, J. MARTIN, S.S. Using AFLP markers to determine the contribution of parental genomes during recurrent selection. Soybean Genetics Newsletter, v.23, p.214-216, 1998.

VELLO, N.A. Caracterização genética e comparação de métodos de melhoramento de plantas autógamas pela metodologia de Cockerham. Piracicaba: SGAEA - publicação didática n.3, 1985. 25p.

VELLO, N.A.; FEHR, W.R.; BAHRENFUS, J.B. Genetic variability and agronomic performance of soybean populations developed from plant introductions. Crop Science, v.24, p.511-514, 1984.

VENCOVSKY, R.; BARRIGA, P. Genética biométrica no fitomelhoramento. Ribeirão Preto: Revista Brasileira de Genética, 1992. 496p.

VILARINHOS, A.D.; BARROS, E.G.; PAIVA, E.; SEDIYAMA, C.S.; MOREIRA, M.A. Use of the random amplified polymorphic DNA technique to characterize soybean (Glycine max (L.) Merrill) genotypes. Revista Brasileira de Genética, v.17, n.3, p.287-290, 1994.

XIAO, J.; LI, J.; YUAN, L. MCCOUCH; S.R.; TANKSLEY, S.D. Genetic diversity and its relationship to hybrid performance and heterosis in rice as revealed by PCRbased markers. Theoretical and Applied Genetics, v. 92, p. 637-643, 1996. 
APENNDICE 
Tabela 80 Resumo das análises de variância ao nivel de linhagens dentro das populações para o caráter altura das plantas na maturação.

\begin{tabular}{|c|c|c|c|c|c|c|c|c|c|c|c|}
\hline \multirow[b]{2}{*}{ Pop. } & \multirow[b]{2}{*}{ F.V. } & \multicolumn{2}{|r|}{$\mathrm{F}_{2: 8}$} & \multicolumn{2}{|r|}{$\mathrm{F}_{2 \cdot 9}$} & \multicolumn{2}{|r|}{$F_{2: 10}$} & \multicolumn{2}{|r|}{$F_{2: 11}$} & \multicolumn{2}{|c|}{ Conjunta } \\
\hline & & GL & $Q M$ & $\overline{G L}$ & $Q M$ & GL & QM & $\mathrm{GL}$ & QM & $G L$ & QM \\
\hline \multirow{3}{*}{$1 \times 2$} & Linhag. & 19 & $507,01^{\star \star}$ & 19 & 218,71 & 19 & $363,95^{\star \star}$ & 18 & 66,11 & 19 & $1340,32^{\star \star}$ \\
\hline & Lx Ano & & & & & & & & & 56 & $200,54^{\star \star}$ \\
\hline & Resid. & 38 & 90,35 & 19 & 500,01 & 38 & 94,01 & 35 & 70,95 & 130 & 85,00 \\
\hline \multirow{3}{*}{$1 \times 3$} & Linhag. & 19 & 212,51 & 19 & $114,00^{\star \star}$ & 19 & $147,02^{\star \star}$ & 19 & $306,23^{\star \star}$ & 19 & $490,01^{\star \star}$ \\
\hline & $L \times A n o$ & & & & & & & & & 57 & 96,58 \\
\hline & Resid. & 38 & 119,11 & 19 & 38,71 & 38 & 46,95 & 38 & 96,03 & 133 & 80,41 \\
\hline \multirow{3}{*}{$1 \times 4$} & Linhag. & 12 & 282,30 & 12 & $168,20^{\star \star}$ & 12 & 216,45 & 12 & 225,67 & 12 & $524,14^{\star \star}$ \\
\hline & $L \times A n o$ & & & & & & & & & 36 & 122,83 \\
\hline & Resid. & 24 & 118,28 & 11 & 52,43 & 24 & 94,82 & 24 & 117,17 & 83 & 102,45 \\
\hline \multirow{3}{*}{$1 \times 6$} & Linhag. & 19 & 135,77 & 19 & $216,81^{\star}$ & 12 & $699,54^{\star \star}$ & 19 & 239,92 & 19 & $407,17^{\star \star}$ \\
\hline & Lx Ano & & & & & & & & & 57 & $161,11^{\star}$ \\
\hline & Resíd. & 36 & 101,15 & 19 & 82,25 & 37 & 173,89 & 37 & 191,44 & 128 & 83,53 \\
\hline \multirow{3}{*}{$1 \times 7$} & Linhag. & 19 & 219,43 & 19 & $290,04^{\star}$ & 19 & $257,08^{\star}$ & 19 & $514,61^{\star \star}$ & 19 & $904,07^{\star \star}$ \\
\hline & $L \times$ Ano & & & & & & & & & 57 & 158,57 \\
\hline & Resíd. & 37 & 211,28 & 19 & 114,47 & 37 & 115,98 & 38 & 64,65 & 132 & 127,06 \\
\hline \multirow{3}{*}{$1 \times 8$} & Linhag. & 19 & $294,96^{\star}$ & 19 & 231,72 & 19 & $148,77^{\star}$ & 19 & 265,91 & 19 & $396,94^{\star \star}$ \\
\hline & $L \times A n o$ & & & & & & & & & 57 & 139,83 \\
\hline & Resid. & 38 & 132,21 & 19 & 142,72 & 38 & 55,55 & 37 & 209,21 & 132 & 112,87 \\
\hline \multirow{3}{*}{$2 \times 3$} & Linhag. & 19 & $468,75^{\star \star}$ & 19 & $707,76^{\star \star}$ & 19 & $371,84^{\star \star}$ & 19 & 125,96 & 19 & $1362,78^{\star \star}$ \\
\hline & $L \times A n o$ & & & & & & & & & 57 & $204,69^{\star \star}$ \\
\hline & Resíd. & 38 & 108,68 & 19 & 49,83 & 38 & 61,58 & 38 & 302,40 & 133 & 78,02 \\
\hline \multirow{3}{*}{$2 \times 4$} & Linhag. & 19 & $787,28^{\text {** }}$ & 19 & $666,28^{\text {* }}$ & 19 & $665,56^{\star \star}$ & 19 & $573,25^{\star \star}$ & 19 & $1969,01^{\star \star}$ \\
\hline & Lx Ano & & & & & & & & & 57 & $187,20^{\star}$ \\
\hline & Resíd. & 38 & 96,46 & 19 & 89,23 & 37 & 213,49 & 38 & 89,79 & 132 & 111,13 \\
\hline \multirow{3}{*}{$2 \times 5$} & Linhag. & 19 & $929,89^{\star \star}$ & 19 & 795,50 & 19 & 508,94 & 19 & $636,17^{\star \star}$ & 19 & $2509,62^{\star \star}$ \\
\hline & $L \times A n o$ & & & & & & & & & 57 & 129,72 \\
\hline & Resid. & 38 & 182,34 & 19 & 61,69 & 35 & 402,23 & 38 & 91,79 & 127 & 120,93 \\
\hline \multirow{3}{*}{$2 \times 6$} & Linhag. & 19 & 256,40 & 19 & $321,95^{\star}$ & 19 & $541,81^{*}$ & 19 & $444,86^{\star \star}$ & 19 & $925,79^{\star \star}$ \\
\hline & LxAno & & & & & & & & & 57 & 163,85 \\
\hline & Resid. & 38 & 153,38 & 19 & 133,16 & 36 & 145,09 & 38 & 88,67 & 132 & 117,03 \\
\hline \multirow{3}{*}{$2 \times 8$} & Linhag. & 19 & $444,04^{\star \star}$ & 19 & $312,70^{\star \star}$ & 19 & 431,11 & 19 & $963,93^{\star \star}$ & 19 & $1168,14^{\star \star}$ \\
\hline & Lx Ano & & & & & & & & & 57 & $314,62^{\star \star}$ \\
\hline & Resid. & 38 & 122,90 & 19 & 75,59 & 37 & 228,21 & 38 & 151,95 & 132 & 111,22 \\
\hline \multirow{3}{*}{$3 \times 5$} & Linhag. & 19 & $259,04^{\star \star}$ & 19 & $152,13^{\star}$ & 19 & $215,33^{\star \star}$ & 19 & $146,89^{\star}$ & 19 & $461,26^{\star \star}$ \\
\hline & Lx Ano & & & & & & & & & 57 & $100,24^{\star}$ \\
\hline & Resid. & 38 & 43,95 & 19 & 53,90 & 38 & 64,01 & 38 & 66,04 & 133 & 59,05 \\
\hline \multirow{3}{*}{$3 \times 6$} & Linhag. & 19 & $322,44^{\star \star}$ & 19 & 213,03 & 19 & $226,73^{\star}$ & 19 & 178,70 & 19 & $669,72^{\star \star}$ \\
\hline & Lx Ano & & & & & & & & & 57 & 90,39 \\
\hline & Resíd. & 38 & 76,27 & 19 & 127,24 & 38 & 86,67 & 38 & 115,28 & 133 & 97,67 \\
\hline \multirow{3}{*}{$3 \times 7$} & Linhag. & 19 & 344,29 & 19 & $919,18^{\star \star}$ & 19 & $611,22^{\star \star}$ & 19 & $522,82^{\star \star}$ & 19 & $2052,33^{\star \star}$ \\
\hline & $L \times$ Ano & & & & & & & & & 57 & 146,82 \\
\hline & Resid. & 37 & 485,04 & 19 & 94,10 & 36 & 204,71 & 38 & 86,36 & 130 & 115,28 \\
\hline
\end{tabular}


Tabela 80. Resumo das análises de variância ao nivel de linhagens dentro das populações para o caráter altura das plantas na maturação (continuação).

\begin{tabular}{|c|c|c|c|c|c|c|c|c|c|c|c|}
\hline \multirow[b]{2}{*}{ Popul } & \multirow[b]{2}{*}{ F.V. } & \multicolumn{2}{|r|}{$\mathrm{F}_{2: 8}$} & \multicolumn{2}{|r|}{$F_{2: 9}$} & \multicolumn{2}{|r|}{$F_{2: 10}$} & \multicolumn{2}{|r|}{$F_{2: 11}$} & \multicolumn{2}{|c|}{ Conjunta } \\
\hline & & $G L$ & QM & $G L$ & QM & $\overline{G L}$ & QM & $G L$ & $\overline{Q M}$ & $G L$ & QM \\
\hline \multirow{3}{*}{$3 \times 8$} & Linhag. & 19 & 151 & 19 & $440,92^{\star \star}$ & 19 & $389,33^{*}$ & 18 & $296,59^{*}$ & 19 & 1062,1 \\
\hline & & & & & & & & & & 56 & 114,6 \\
\hline & & 38 & 271,19 & 19 & 72,33 & 37 & $144,32^{\star}$ & 36 & 130,36 & 130 & 89,30 \\
\hline \multirow{3}{*}{$4 \times 5$} & & 19 & 79 & 19 & $109,30^{\prime}$ & 19 & $120,96^{\star}$ & 19 & 160,44 & 19 & $317,79^{\star \star}$ \\
\hline & & & & & & & & & & 57 & 84,24 \\
\hline & $\mathrm{Re}$ & 38 & 65,92 & 19 & 37,56 & 38 & 50,37 & 38 & 93,93 & 133 & 65,43 \\
\hline \multirow{3}{*}{$4 \times 6$} & & 19 & & 19 & 513,0 & 19 & $628,61^{\star \star}$ & 19 & $457,76^{\star \star}$ & 19 & $1551,37^{\star \star}$ \\
\hline & $L \times$ & & & & & & & & & 57 & $123,36^{\star}$ \\
\hline & $R$ & 38 & 108,06 & 18 & 74,53 & 36 & 65,04 & 38 & 45,48 & 130 & 69,31 \\
\hline \multirow{3}{*}{$4 \times 7$} & & 19 & 606 & 19 & $556,22^{\star \star}$ & 19 & 306,38 & 19 & $558,25^{\star \star}$ & 19 & $1632,46^{\star \star}$ \\
\hline & 0 & & & & & & & & & 57 & 131,57 \\
\hline & 0 & 38 & 147 & 19 & 81,34 & 38 & 156,64 & 38 & 83,71 & 133 & 122,55 \\
\hline \multirow{3}{*}{$4 \times 8$} & & 19 & 217 & 19 & $326,70^{*}$ & 19 & $163,51^{*}$ & 19 & 183,77 & 19 & $583,87^{\star \star}$ \\
\hline & & & & & & & & & & 57 & 102,49 \\
\hline & Res & 38 & 100 & 19 & 131,59 & 38 & 74,04 & 38 & 113,97 & 133 & 101,35 \\
\hline \multirow{3}{*}{$5 \times 6$} & & 19 & 8 & 19 & $105,45^{\star}$ & 19 & $159,19^{\star \star}$ & 19 & 137,23 & 19 & $239,55^{\star \star}$ \\
\hline & 10 & & & & & & & & & 57 & 84,04 \\
\hline & 10 & 38 & 108 & 18 & 54,03 & 38 & 50,50 & 38 & 68,22 & 132 & 72,81 \\
\hline \multirow{3}{*}{$x 7$} & & 19 & * & 19 & $48,69^{\star}$ & 19 & $582,87^{\star \star}$ & 19 & $427,17^{\star \star}$ & 19 & $1598,55^{\star \star}$ \\
\hline & & & & & & & & & & 57 & $245,45^{\star \star}$ \\
\hline & 10 & 38 & 123 & 19 & 97,76 & 38 & 102,74 & 38 & 116,78 & 133 & 112,02 \\
\hline \multirow{3}{*}{$5 \times 8$} & & 19 & 188,72 & 19 & $737,28^{\star \star}$ & 19 & $359,01^{\star}$ & 19 & $422,37^{\star \star}$ & 19 & $1073,39^{\star \star}$ \\
\hline & & & & & & & & & & 57 & $211,33^{\star \star}$ \\
\hline & $\mathrm{R}$ & 38 & 129 & 19 & 106 & 38 & 139,28 & 38 & 117,63 & 133 & 125,47 \\
\hline \multirow{3}{*}{$6 \times 7$} & & 19 & $372,05^{\star \star}$ & 19 & $48,13^{\star \star}$ & 19 & $557,34^{\star \star}$ & 19 & $724,98^{\star \star}$ & 19 & $1534,52^{\star \star}$ \\
\hline & & & & & & & & & & 57 & $207,71^{\star \star}$ \\
\hline & & 38 & & 19 & 35 , & 36 & 18 & 38 & 72,22 & 131 & 74,33 \\
\hline \multirow{3}{*}{$6 \times 8$} & $\mathrm{~L}$ & 19 & 242,77 & 19 & $695,15^{\star \star}$ & 19 & 302,00 & 19 & $407,97^{\star \star}$ & 19 & $1068,06^{\star \star}$ \\
\hline & & & & & & & & & & 57 & 175,27 \\
\hline & $\operatorname{Res}$ & 38 & 146 & 19 & 120,42 & 37 & 18 & 38 & 136,11 & $\begin{array}{l}132 \\
132\end{array}$ & 132,71 \\
\hline \multirow{3}{*}{$x 8$} & Linhag. & 19 & $403,65^{\star \star}$ & 19 & $658,49^{\star \star}$ & 19 & 223,48 & 19 & $520,09^{\star \star}$ & 19 & $988,10^{\star \star}$ \\
\hline & & & & & & & & & & 57 & $272,53^{\star}$ \\
\hline & Resi & 38 & 60,05 & 18 & 186,26 & 38 & 221,31 & 38 & 131,34 & 132 & 172,99 \\
\hline
\end{tabular}


Tabela 81 Resumo das análises de variância ao nível de linhagens dentro das populações para o caráter produtividade de grãos

\begin{tabular}{|c|c|c|c|c|c|c|c|c|c|c|c|}
\hline \multirow[b]{2}{*}{ Pop } & \multirow[b]{2}{*}{ F.V. } & \multicolumn{2}{|r|}{$F_{2: 8}$} & \multicolumn{2}{|r|}{$F_{2: 9}$} & \multicolumn{2}{|r|}{$F_{2: 10}$} & \multicolumn{2}{|r|}{$F_{2: 11}$} & \multicolumn{2}{|r|}{ Conjunta } \\
\hline & & $G L$ & QM & $G L$ & $Q M$ & $G L$ & QM & GL & $Q M$ & $G L$ & $Q M$ \\
\hline \multirow{3}{*}{$1 \times 2$} & Linhag. & 19 & 11736,60 & 19 & $8391,42^{\star}$ & 19 & 4264,99 & & $44343,40^{\star \star}$ & 19 & $8484,90^{* \star}$ \\
\hline & Lx Ano & & & & & & & & & 56 & $6793,50^{\star \star}$ \\
\hline & Resíd. & 38 & 6209,97 & 37 & 3669,93 & 37 & 4309,93 & 35 & 849,08 & 147 & 3816,00 \\
\hline \multirow{3}{*}{$1 \times 3$} & Linhag. & 19 & 9701,25 & 19 & $11717,50^{\star}$ & 19 & $5425,32^{\star}$ & & $4693,40^{\star \star}$ & 19 & $17659,00^{\star \star}$ \\
\hline & $L \times A n o$ & & & & & & & & & 57 & 4625,98 \\
\hline & Resid. & 38 & 6600,58 & 37 & 5059,63 & 36 & 2593,95 & 38 & 1621,20 & 149 & 3979,97 \\
\hline \multirow{3}{*}{$1 \times 4$} & Linhag. & 12 & $39823,00^{\star \star}$ & 12 & $24435,00^{\star \star}$ & 12 & $15300,00^{\star \star}$ & & $7702,90^{\star \star}$ & 12 & $51701,00^{\star \star}$ \\
\hline & $L \times$ Ano & & & & & & & & & 36 & $11853,00^{\star \star}$ \\
\hline & Resíd. & 24 & 12510,60 & 22 & 6202,43 & 24 & 4479,83 & 23 & 2528,73 & 93 & 6477,25 \\
\hline \multirow[t]{2}{*}{$1 \times 6$} & $\begin{array}{l}\text { Linhag. } \\
\text { Lx Ano }\end{array}$ & 19 & 4686,85 & 19 & $6591,60^{\star \star}$ & 19 & $6165,70^{\star \star}$ & & $3571,60^{\star \star}$ & $\begin{array}{l}19 \\
57\end{array}$ & $\begin{array}{l}10020,00^{\star \star} \\
3665,20^{\text {** }}\end{array}$ \\
\hline & Resid. & 34 & 2896,52 & 37 & 1782,24 & 36 & 1727,37 & 35 & 1036,80 & 142 & 1851,39 \\
\hline \multirow{3}{*}{$1 \times 7$} & Linhag. & 19 & 4572,52 & 19 & 3577,59 & 19 & 2345,36 & & 1463,91 & 19 & $4608,20^{\star \star}$ \\
\hline & LxAno & & & & & & & & & 57 & 2450,39 \\
\hline & Resid. & 36 & 2565,36 & 36 & 3264,33 & 37 & 1515,03 & 37 & 1124,78 & 146 & 2106,45 \\
\hline \multirow{3}{*}{$1 \times 8$} & Linhag. & 19 & 7855,09 & 19 & 7018,66 & 19 & 3820,92 & & 3451,30 & 19 & $7098,78^{\star}$ \\
\hline & $L \times$ Ano & & & & & & & & & 57 & 5015,73 \\
\hline & Resíd. & 37 & 5911,74 & 37 & 5698,10 & 38 & 2528,17 & 37 & 1846,07 & 149 & 3986,17 \\
\hline \multirow{3}{*}{$2 \times 3$} & Linhag. & 19 & $17255,00^{\star \star}$ & 19 & 11323,48 & 19 & 3554,20 & & 3049,14 & 19 & $19044,00^{\star \star}$ \\
\hline & Lx Ano & & & & & & & & & 57 & 5379,12 \\
\hline & Resíd. & 38 & 4875,88 & 37 & 6492,06 & 37 & 4507,17 & 38 & 2815,54 & 150 & 4661,64 \\
\hline \multirow{3}{*}{$2 \times 4$} & Linhag. & 19 & $12080,20^{\star}$ & 19 & $9389,33^{\star}$ & 19 & $7862,78^{\star}$ & & $4913,60^{\star \star}$ & 19 & $21444,00^{\star \star}$ \\
\hline & LxAno & & & & & & & & & 57 & 4267,27 \\
\hline & Resid. & 37 & 4788,68 & 38 & 4524,35 & 35 & 3504,73 & 38 & 1305,61 & 148 & 3522,87 \\
\hline \multirow{3}{*}{$2 \times 5$} & Linhag. & 19 & $11876,60^{*}$ & 19 & 9488,26 & 19 & 6042,98 & & $3914,40^{\star}$ & 19 & $23186,00^{\star \star}$ \\
\hline & LxAno & & & & & & & & & 57 & 2711,95 \\
\hline & Resíd. & 38 & 5500,15 & 36 & 6830,52 & 38 & 3146,88 & 38 & 1431,89 & 150 & 4192,65 \\
\hline \multirow{3}{*}{$2 \times 6$} & Linhag. & 19 & $9640,20^{\star \star}$ & 19 & $7418,03^{*}$ & 19 & 4762,84 & 19 & $3884,00^{\star \star}$ & 19 & $14018,00^{\star \star}$ \\
\hline & $L \times A n o$ & & & & & & & & & 57 & $3895,79^{\star}$ \\
\hline & Resid. & 38 & 2601,29 & 38 & 2801,56 & 36 & 2940,19 & 38 & 1376,96 & 150 & 2423,20 \\
\hline \multirow{3}{*}{$2 \times 8$} & Linhag. & 19 & 6102,30 & 19 & 6895,84 & 19 & $7582,10^{\star \star}$ & & $2781,60^{\star}$ & 19 & $10034,00^{\star \star}$ \\
\hline & $L \times A n o$ & & & & & & & & & 57 & 4442,47 \\
\hline & Resíd. & 38 & 3650,73 & 37 & 6878,22 & 36 & 2276,78 & 38 & 1266,11 & 149 & 3512,07 \\
\hline \multirow{3}{*}{$3 \times 5$} & Linhag. & 19 & $11298,00^{\star \star}$ & 19 & 13694,80 & 19 & 8172,46 & & 4457,58 & 19 & $22828,00^{\star \star}$ \\
\hline & Lx Ano & & & & & & & & & 57 & 4931,42 \\
\hline & Resíd. & 37 & 2665,49 & 34 & 6951,66 & 38 & 4266,14 & & 2691,28 & 147 & 4077,29 \\
\hline \multirow{3}{*}{$3 \times 6$} & Linhag. & 19 & $10971,00^{\star \star}$ & 19 & 5026,23 & 19 & $7974,78^{\star}$ & 19 & $4308,90^{\star}$ & 19 & $18972,00^{\star \star}$ \\
\hline & $L \times$ Ano & & & & & & & & & 57 & 3102,82 \\
\hline & Resíd. & 38 & 2013,01 & 34 & 2573,12 & 38 & 3487,39 & 38 & 1691,69 & 148 & 2437,74 \\
\hline \multirow{3}{*}{$3 \times 7$} & Linhag. & 19 & $12467,00^{\star \star}$ & 19 & $11881,00^{\star \star}$ & 19 & 6599,94 & & $5406,20^{\star}$ & 19 & $25336,00^{\star \star}$ \\
\hline & $L \times A$ no & & & & & & & & & 57 & 3673,10 \\
\hline & Resíd. & 36 & 4613,81 & 37 & 4186,69 & 36 & 4508,37 & 37 & 1378,93 & 146 & 3659,77 \\
\hline
\end{tabular}


Tabela 81 Resumo das análises de variância ao nivel de linhagens dentro das populações para o caráter produtividade de grãos (continuação)

\begin{tabular}{|c|c|c|c|c|c|c|c|c|c|c|c|}
\hline \multirow[b]{2}{*}{ Popul } & \multirow[b]{2}{*}{ F.V. } & \multicolumn{2}{|r|}{$F_{2: 8}$} & \multicolumn{2}{|r|}{$F_{2: 9}$} & \multicolumn{2}{|r|}{$F_{2: 10}$} & \multicolumn{2}{|r|}{$F_{2: 11}$} & \multicolumn{2}{|r|}{ Conjunta } \\
\hline & & GL & QM & GL & QM & $\begin{array}{l}G \\
L\end{array}$ & QM & $G L$ & QM & $\overline{G L}$ & QM \\
\hline \multirow{3}{*}{$3 \times 8$} & Linhagem & 19 & 6735,34 & 19 & 10516,50 & 19 & $8326,40^{\star \star}$ & 18 & $4563,40^{\star}$ & 19 & $16799,00^{\star \star \star}$ \\
\hline & $L \times$ Ano & & & & & & & & & 56 & 4445,12 \\
\hline & Residuo & 38 & 4354,19 & 38 & 5390,95 & 37 & 2513,26 & 34 & 2090,17 & 147 & 3635,18 \\
\hline \multirow{3}{*}{$4 \times 5$} & Linhagem & 19 & $17062,00^{\star \star}$ & 19 & $18713,00^{\star}$ & 19 & $6178,46^{\star}$ & 19 & 2169,32 & 19 & $21112,00^{\star \star}$ \\
\hline & Lx Ano & & & & & & & & & 57 & $7670,20^{\star}$ \\
\hline & Resíduo & 38 & 6530,56 & 37 & 7519,70 & 36 & 2717,12 & 38 & 2285,05 & 149 & 4772,07 \\
\hline \multirow{3}{*}{$4 \times 6$} & Linhagem & 19 & $21793,00^{\star \star}$ & 19 & $13382,00^{\star}$ & 19 & $5316,10^{\star \star}$ & 19 & $7136,00^{\star \star}$ & 19 & $31721,00^{\star \star}$ \\
\hline & $L \times$ Ano & & & & & & & & & 57 & $5302,50^{\star \star}$ \\
\hline & Resíduo & 37 & 2829,49 & 36 & 4538,03 & 36 & 1869,33 & 38 & 900,81 & 147 & 2514,20 \\
\hline \multirow{3}{*}{$4 \times 7$} & Linhagem & 19 & 8432,91 & 19 & 9654,48 & 19 & 5104,79 & 19 & $4056,40^{\star \star}$ & 19 & $13801,00^{\star \star}$ \\
\hline & Lx Ano & & & & & & & & & 57 & 4482,45 \\
\hline & Residuo & 38 & 6669,52 & 36 & 5018,89 & 37 & 3477,56 & 38 & 1229,39 & 149 & 4090,66 \\
\hline \multirow{3}{*}{$4 \times 8$} & Linhagem & 19 & 6399,85 & 19 & 4521,03 & 19 & 4754,09 & 19 & 2641,83 & 19 & 4619,54 \\
\hline & LxAno & & & & & & & & & 57 & 4565,75 \\
\hline & Residuo & 38 & 5329,29 & 18 & 7294,91 & 37 & 3345,79 & 36 & 3426,24 & 129 & 4503,57 \\
\hline \multirow{3}{*}{$5 \times 6$} & Linhagem & 19 & $12437,00^{\star \star}$ & 19 & 8927,13 & 19 & $10014,00^{\star \star}$ & 19 & $5993,00^{\star \star}$ & 19 & $20554,00^{\star \star}$ \\
\hline & Lx Ano & & & & & & & & & 57 & $5605,90^{\star \star}$ \\
\hline & Resíduo & 38 & 2075,34 & 36 & 5164,66 & 37 & 2451,50 & 38 & 1027,05 & 149 & 2647,81 \\
\hline \multirow{3}{*}{$5 \times 7$} & Linhagem & 19 & $7260,00^{\star \star}$ & 19 & 5804,75 & 19 & $4303,25^{\star}$ & 19 & $5010,10^{\star \star}$ & 19 & $10216,00^{\star \star}$ \\
\hline & $L \times$ Ano & & & & & & & & & 57 & $4054,20^{\star \star}$ \\
\hline & Resíduo & 38 & 3259,74 & 37 & $2766,60^{\star}$ & 37 & 1973,15 & 38 & 971,58 & 150 & 2241,07 \\
\hline \multirow{3}{*}{$5 \times 8$} & Linhagem & 19 & 5199,66 & 19 & 6531,48 & 19 & 3793,95 & 19 & 2082,01 & 19 & $8402,60^{\star \star}$ \\
\hline & LxAno & & & & & & & & & 57 & 3068,15 \\
\hline & Resíduo & 38 & 5259,57 & 38 & 3884,09 & 38 & 2103,94 & 38 & 1837,10 & 152 & 3271,18 \\
\hline \multirow{3}{*}{$6 \times 7$} & Linhagem & 19 & $13404,00^{\star \star}$ & 19 & $17067,00^{\star \star}$ & 19 & $10780,00^{\star \star}$ & 19 & $4264,50^{\star \star}$ & 19 & $33052,00^{\star \star}$ \\
\hline & $L \times$ Ano & & & & & & & & & 57 & $4154,60^{\star \star}$ \\
\hline & Resíduo & 38 & 4477,70 & 36 & 2280,59 & 32 & 1950,06 & 38 & 722,07 & 144 & 2375,65 \\
\hline \multirow{3}{*}{$6 \times 8$} & Linhagem & 19 & $17015,00^{\star \star}$ & 19 & $13584,40^{\star}$ & 19 & $5613,50^{\star \star}$ & 19 & $3408,90^{\star \star}$ & 19 & $22230,00^{\star \star}$ \\
\hline & Lx Ano & & & & & & & & & 57 & $5797,15^{\star \star}$ \\
\hline & Resíduo & 34 & 5260,29 & 32 & 4951,19 & 37 & 1977,65 & 38 & 1187,50 & 141 & 3231,10 \\
\hline \multirow{3}{*}{$7 \times 8$} & Linhagem & 19 & $6995,90^{\star \star}$ & 19 & 3983,79 & 19 & 3649,58 & 19 & $6068,90^{\star *}$ & 19 & $11046,00^{\star \star}$ \\
\hline & & & & & & & & & & 57 & 3217,29 \\
\hline & Resíduo & 38 & 3134,82 & 36 & 3202,15 & 36 & 2128,30 & 37 & 735,73 & 147 & 2300,96 \\
\hline
\end{tabular}


Tabela 82 Resumo das análises de variância ao nivel de linhagens dentro das populações para o caráter altura das plantas no florescimento.

\begin{tabular}{|c|c|c|c|c|c|c|c|c|c|}
\hline \multirow[b]{2}{*}{ População } & \multirow[b]{2}{*}{ F.V. } & \multicolumn{2}{|c|}{$F_{2: 9}$} & \multicolumn{2}{|c|}{$F_{2: 10}$} & \multicolumn{2}{|c|}{$F_{2: 11}$} & \multicolumn{2}{|c|}{ Conjunta } \\
\hline & & $G L$ & QM & GL & QM & $G L$ & QM & GL & QM \\
\hline \multirow{3}{*}{$1 \times 2$} & Linhagem & 19 & 71,65 & 19 & $230,83^{\star \star}$ & 18 & 25,32 & 19 & $208,39^{\star \star}$ \\
\hline & Lx Ano & & & & & & & 37 & 60,63 \\
\hline & Residuo & 19 & 47,02 & 38 & 84,59 & 35 & 26,09 & 92 & 54,57 \\
\hline \multirow{3}{*}{$1 \times 3$} & Linhagem & 19 & 42,52 & 19 & $208,53^{\star \star}$ & 19 & $98,62^{\star \star}$ & 19 & $238,67^{\star \star}$ \\
\hline & Lx Ano & & & & & & & 38 & 55,50 \\
\hline & Residuo & 19 & 23,17 & 38 & 78,26 & 38 & 27,17 & 95 & 46,80 \\
\hline \multirow{3}{*}{$1 \times 4$} & Linhagem & 12 & 70,13 & 12 & $139,72^{\star \star}$ & 12 & $53,56^{\star}$ & 12 & $135,53^{\star \star}$ \\
\hline & L $\times$ Ano & & & & & & & 24 & $63,64^{\star \star}$ \\
\hline & Residuo & 11 & 38,11 & 18 & 35,82 & 24 & 22,76 & 53 & 30,38 \\
\hline \multirow{3}{*}{$1 \times 6$} & Linhagem & 19 & $133,89^{*}$ & 19 & $408,75^{\star \star \star}$ & 19 & $95,82^{\star \star}$ & 19 & $321,40^{\star \star \hbar}$ \\
\hline & Lx Ano & & & & & & & 38 & $158,53^{\star}$ \\
\hline & Residuo & 19 & 59,33 & 37 & 154,81 & 37 & 32,64 & 93 & 86,70 \\
\hline \multirow{3}{*}{$1 \times 7$} & Linhagem & 19 & $88,89^{\star}$ & 19 & $435,54^{\star \star}$ & 19 & $111,63^{\star \star}$ & 19 & $292,17^{\star \star}$ \\
\hline & Lx Ano & & & & & & & 38 & $171,94^{\star \star}$ \\
\hline & Resíduo & 19 & 31,99 & 27 & 75,18 & 38 & 29,67 & 84 & 44,83 \\
\hline \multirow{3}{*}{$1 \times 8$} & Linhagem & 19 & $123,88^{\star}$ & 19 & $163,59^{*}$ & 19 & 75,77 & 19 & $153,71^{\star \star}$ \\
\hline & $L \times$ Ano & & & & & & & 38 & $104,76^{\star}$ \\
\hline & Residuo & 19 & 47,76 & 20 & 71,77 & 37 & 76,06 & 76 & 67,36 \\
\hline \multirow{3}{*}{$2 \times 3$} & Linhagem & 19 & 73,32 & 19 & $235,13^{*}$ & 19 & 57,05 & 19 & $192,89^{\star k}$ \\
\hline & LxAno & & & & & & & 38 & 86,31 \\
\hline & Resíduo & 19 & 38,58 & 38 & 116,79 & 38 & 35,14 & 95 & 68,49 \\
\hline \multirow{3}{*}{$2 \times 4$} & Linhagem & 19 & $63,96^{\star}$ & 19 & $363,02^{*}$ & 19 & $57,59^{\star \star}$ & 19 & $243,61^{\star \star}$ \\
\hline & L $\times$ Ano & & & & & & & 38 & 120,48 \\
\hline & Residuo & 19 & 29,17 & 30 & 194,09 & 38 & 22,80 & 87 & 83,26 \\
\hline \multirow{3}{*}{$2 \times 5$} & Linhagem & 19 & $84,11^{*}$ & 19 & $304,80^{\star \star}$ & 19 & $99,16^{\star \star}$ & 19 & $335,49^{\star \star}$ \\
\hline & LX Ano & & & & & & & 38 & 76,29 \\
\hline & Residuo & 19 & 30,97 & 32 & 94,62 & 38 & 39,50 & 89 & 57,50 \\
\hline \multirow{3}{*}{$2 \times 6$} & Linhagem & 19 & 56,17 & 19 & $252,43^{\star \star}$ & 19 & $82,75^{\star \star}$ & 19 & $206,47^{\star \star}$ \\
\hline & $L \times$ Ano & & & & & & & 38 & $92,44^{\star}$ \\
\hline & Residuo & 19 & 31,38 & 37 & 85,45 & 38 & 30,62 & 94 & 52,35 \\
\hline \multirow{3}{*}{$2 \times 8$} & Linhagem & 19 & $288,05^{\star \star}$ & 19 & $483,50^{\star \star}$ & 19 & $100,63^{\star \star}$ & 19 & $277,89^{\star \star \star}$ \\
\hline & LX Ano & & & & & & & 38 & $297,14^{\star \star \star}$ \\
\hline & Residuo & 19 & 93,30 & 38 & 128,80 & 38 & 29,62 & 95 & 82,03 \\
\hline \multirow{3}{*}{$3 \times 5$} & Linhagem & 19 & 37,51 & 19 & $151,24^{\star \star}$ & 19 & 74,40 & 19 & $153,02^{\star \star}$ \\
\hline & $L \times$ Ano & & & & & & & 38 & 55,07 \\
\hline & Resíduo & 19 & 41,23 & 36 & 56,22 & 38 & 49,50 & 93 & 50,41 \\
\hline \multirow{3}{*}{$3 \times 6$} & Linhagem & 19 & 131,48 & 19 & $314,64^{\star \star}$ & 19 & $95,19^{\star \star}$ & 19 & $337,52^{\star \star}$ \\
\hline & $L \times A n o$ & & & & & & & 38 & 101,89 \\
\hline & Resíduo & 19 & 83,72 & 38 & 102,89 & 38 & 20,51 & 95 & 66,10 \\
\hline \multirow{3}{*}{$3 \times 7$} & Linhagem & 19 & $189,19^{\star \star}$ & 19 & 181,92 & 19 & $55,07^{\star}$ & 19 & 250,75 \\
\hline & $L \times$ Ano & & & & & & & 38 & 87,72 \\
\hline & Resíduo & 19 & 35,58 & 28 & 155,66 & 38 & 23,20 & 85 & 69,60 \\
\hline
\end{tabular}


Tabela 82 Resumo das análises de variância ao nivel de linhagens dentro das populações para o caráter altura das plantas no florescimento (continuação).

\begin{tabular}{|c|c|c|c|c|c|c|c|c|c|}
\hline \multirow[b]{2}{*}{ População } & \multirow[b]{2}{*}{$F, V$, } & \multicolumn{2}{|c|}{$\mathrm{F}_{2.9}$} & \multicolumn{2}{|c|}{$\mathrm{F}_{2: 10}$} & \multicolumn{2}{|c|}{$F_{2: 11}$} & \multicolumn{2}{|c|}{ Conjunta } \\
\hline & & $G L$ & $Q M$ & $G L$ & QM & GL & QM & GL & QM \\
\hline \multirow{3}{*}{$3 \times 8$} & Linhagem & 19 & $180,72^{\star \star}$ & 19 & $279,63^{\star \star}$ & 18 & $190,44^{\star \star}$ & 19 & $475,31^{\star \star}$ \\
\hline & $L \times$ Ano & & & & & & & 37 & $84,96^{\star \star}$ \\
\hline & Residuo & 19 & 59,71 & 18 & 50,61 & 36 & 45,76 & 73 & 20,59 \\
\hline \multirow{3}{*}{$4 \times 5$} & Linhagem & 19 & 58,97 & 19 & $155,19^{\star \star}$ & 19 & $82,47^{\star}$ & 19 & $175,88^{\star \star}$ \\
\hline & LxAno & & & & & & & 38 & 60,37 \\
\hline & Residuo & 19 & 55,96 & 28 & 53,10 & 38 & 39,16 & 85 & 47,50 \\
\hline \multirow{3}{*}{$4 \times 6$} & Linhagem & 19 & $170,88^{\star}$ & 19 & $338,65^{\star}$ & 19 & $169,57^{\star \star}$ & 19 & $538,46^{\star \star}$ \\
\hline & Lx Ano & & & & & & & 38 & 70,32 \\
\hline & Residuo & 18 & 79,78 & 36 & 159,75 & 38 & 21,67 & 92 & 87,07 \\
\hline \multirow{3}{*}{$4 \times 7$} & Linhagem & 19 & $74,68^{*}$ & 19 & $550,53^{\star \star}$ & 19 & $96,93^{\star \star}$ & 19 & $404,99^{\star \star}$ \\
\hline & Lx Ano & & & & & & & 38 & $158,57^{\star \star}$ \\
\hline & Residuo & 19 & 27,14 & 25 & 103,43 & 38 & 15,63 & 82 & 45,07 \\
\hline \multirow{3}{*}{$4 \times 8$} & Linhagem & 19 & $306,59^{\star}$ & 19 & $306,23^{\star \star}$ & 19 & $128,46^{\star \star}$ & 19 & $426,71^{\star \star}$ \\
\hline & L x Ano & & & & & & & 38 & $157,28^{\star \star}$ \\
\hline & Resíduo & 19 & 107,02 & 38 & 121,54 & 38 & 39,53 & 95 & 85,83 \\
\hline \multirow{3}{*}{$5 \times 6$} & Linhagem & 19 & 52,86 & 19 & 159,92 & 19 & $81,13^{\star \star}$ & 19 & $111,53^{\star}$ \\
\hline & Lx Ano & & & & & & & 38 & $91,19^{\star}$ \\
\hline & Residuo & 18 & 38,82 & 38 & 101,47 & 38 & 27,32 & 94 & 59,50 \\
\hline \multirow{3}{*}{$5 \times 7$} & Linhagem & 19 & 59,33 & 19 & 113,22 & 19 & $46,08^{\star \star \star}$ & 19 & $92,22^{\star \star}$ \\
\hline & Lx Ano & & & & & & & 38 & $63,20^{\star}$ \\
\hline & Resíduo & 19 & 16,40 & 35 & 86,75 & 38 & 19,88 & 92 & 40,60 \\
\hline \multirow{3}{*}{$5 \times 8$} & Linhagem & 19 & 168,08 & 19 & 210,42 & 19 & $144,87^{\star \star}$ & 19 & $377,54^{\star \star}$ \\
\hline & Lx Ano & & & & & & & 38 & 72,91 \\
\hline & Residuo & 19 & 79,50 & 20 & 146,22 & 38 & 39,87 & 77 & 77,27 \\
\hline \multirow{3}{*}{$6 \times 7$} & Linhagem & 19 & $76,02^{\star \star}$ & 19 & $323,32^{\star}$ & 19 & $79,54^{\star \star}$ & 19 & $314,78^{\star \star}$ \\
\hline & Lx Ano & & & & & & & 38 & 82,05 \\
\hline & Residuo & 19 & 23,56 & 57 & 157,75 & 38 & 25,65 & 93 & 76,36 \\
\hline \multirow{3}{*}{$6 \times 8$} & Linhagem & 19 & $98,40^{*}$ & 19 & $289,98^{\star \star}$ & 19 & $104,61^{\star \star}$ & 19 & $294,03^{\star \star}$ \\
\hline & $L \times$ Ano & & & & & & & 38 & $99,48^{*}$ \\
\hline & Resíduo & 19 & 44,81 & 20 & 106,70 & 38 & 32,16 & 77 & 54,64 \\
\hline \multirow{3}{*}{$7 \times 8$} & Linhagem & 19 & 169,33 & 19 & 352,16 & 19 & $94,46^{\star \star}$ & 19 & $341,87^{\star \star}$ \\
\hline & Lx Ano & & & & & & & 38 & 137,04 \\
\hline & Resíduo & 18 & 89,83 & 38 & 194,04 & 38 & 31,01 & 94 & 108,18 \\
\hline
\end{tabular}


Tabela 83 Resumo das análises de variância ao nível de linhagens dentro das populações para o caráter dias para o florescimento

\begin{tabular}{|c|c|c|c|c|c|c|c|c|c|}
\hline \multirow[b]{2}{*}{ População } & \multirow[b]{2}{*}{ F.V. } & \multicolumn{2}{|c|}{$\mathrm{F}_{2: 9}$} & \multicolumn{2}{|c|}{$F_{2: 10}$} & \multicolumn{2}{|c|}{$\overline{F_{2: 11}}$} & \multicolumn{2}{|c|}{ Conjunta } \\
\hline & & $G L$ & QM & GL & QM & $G L$ & QM & GL & QM \\
\hline \multirow{3}{*}{$1 \times 2$} & Linhagem & 19 & $17,65^{\star \star}$ & 19 & $11,77^{\star}$ & 18 & $23,01^{\star \star}$ & 19 & $40,91^{\star \pi}$ \\
\hline & $L \times$ Ano & & & & & & & 37 & 5,29 \\
\hline & Residuo & 19 & 5,29 & 38 & 5,36 & 35 & 3,74 & 92 & 4,73 \\
\hline \multirow{3}{*}{$1 \times 3$} & Linhagem & 19 & $15,69^{\star \star}$ & 19 & 12,35 & 19 & $41,71^{\star \star}$ & 19 & $39,91^{* x}$ \\
\hline & Lx Ano & & & & & & & 38 & $14,92^{\star \star}$ \\
\hline & Residuo & 19 & 3,23 & 38 & 7,15 & 38 & 2,54 & 95 & 4,52 \\
\hline \multirow{3}{*}{$1 \times 4$} & Linhagem & 12 & 0,78 & 12 & $3,63^{\star \star}$ & 12 & $20,03^{\star \star}$ & 12 & $15,37^{* \star}$ \\
\hline & Lx Ano & & & & & & & 24 & $4,54^{\star \star}$ \\
\hline & Residuo & 11 & 0,71 & 18 & 1,41 & 24 & 1,60 & 53 & 1,35 \\
\hline \multirow{3}{*}{$1 \times 6$} & Linhagem & 19 & $5,03^{*}$ & 19 & $16,66^{*}$ & 19 & $19,62^{\star \star}$ & 19 & $26,57^{* \pi}$ \\
\hline & $L \times$ Ano & & & & & & & 38 & $7,37^{\star}$ \\
\hline & Resíduo & 19 & 1,80 & 37 & 7,32 & 37 & 2,41 & 93 & 4,24 \\
\hline \multirow{3}{*}{$1 \times 7$} & Linhagem & 19 & $22,11^{\star}$ & 19 & $22,91^{*}$ & 19 & $31,02^{\star \star}$ & 19 & $55,09^{* *}$ \\
\hline & $L \times$ Ano & & & & & & & 38 & 10,48 \\
\hline & Resíduo & 19 & 9,58 & 27 & 10,31 & 38 & 3,69 & 84 & 7,15 \\
\hline \multirow{3}{*}{$1 \times 8$} & Linhagem & 19 & $17,13^{\star}$ & 19 & $21,63^{*}$ & 19 & $18,89^{\star \star}$ & 19 & $38,48^{* \pi}$ \\
\hline & Lx Ano & & & & & & & 38 & $9,58^{*}$ \\
\hline & Residuo & 19 & 7,34 & 20 & 10,42 & 37 & 2,59 & 76 & 5,84 \\
\hline \multirow{3}{*}{$2 \times 3$} & Linhagem & 19 & $7,56^{\star \star}$ & 19 & $36,30^{\star}$ & 19 & $32,32^{\text {* }}$ & 19 & $47,16^{\star \star}$ \\
\hline & $L \times A n o$ & & & & & & & 38 & 11,25 \\
\hline & Residuo & 19 & 1,03 & 38 & 13,86 & 38 & 4,84 & 95 & 8,99 \\
\hline \multirow{3}{*}{$2 \times 4$} & Linhagem & 19 & 0,81 & 19 & 15,21 & 19 & $12,73^{\star \star}$ & 19 & $17,41^{\star \star}$ \\
\hline & $L \times A$ no & & & & & & & 38 & 5,67 \\
\hline & Residuo & 19 & 0,38 & 30 & 8,54 & 38 & 3,54 & 87 & 4,57 \\
\hline \multirow{3}{*}{$2 \times 5$} & Linhagem & 19 & 2,59 & 19 & $29,41^{\star \star}$ & 19 & $34,99^{\star \star}$ & 19 & $47,79^{\star \star}$ \\
\hline & $L \times$ Ano & & & & & & & 38 & $9,60^{\star}$ \\
\hline & Resíduo & 19 & 1,99 & 31 & 7,94 & 38 & 4,72 & 88 & 5,27 \\
\hline \multirow{3}{*}{$2 \times 6$} & Linhagem & 19 & 3,98 & 19 & $23,71^{\star \star}$ & 19 & $25,84^{\star \star}$ & 19 & $34,39^{\star *}$ \\
\hline & $\mathrm{L} \times$ Ano & & & & & & & 38 & $9,57^{\star}$ \\
\hline & Residuo & 19 & 2,65 & 37 & 7,86 & 38 & 4,20 & 94 & 5,33 \\
\hline \multirow{3}{*}{$2 \times 8$} & Linhagem & 19 & $29,76^{\star \star}$ & 19 & 8,21 & 19 & $25,68^{\star \star}$ & 19 & $44,95 \times$ \\
\hline & Lx Ano & & & & & & & 38 & 9,35 \\
\hline & Residuo & 19 & 5,74 & 38 & 4,88 & 38 & 9,10 & 95 & 6,74 \\
\hline \multirow{3}{*}{$3 \times 5$} & Linhagem & 19 & 4,28 & 19 & 8,30 & 19 & $27,83^{\star \star}$ & 19 & $29,90^{* \star}$ \\
\hline & Lx Ano & & & & & & & 38 & 5,62 \\
\hline & Resíduo & 19 & 2,38 & 34 & 4,77 & 38 & 4,16 & 91 & 3,86 \\
\hline \multirow{3}{*}{$3 \times 6$} & Linhagem & 19 & $27,97^{\star \star}$ & 19 & $31,08^{\star \star}$ & 19 & $42,30^{\star \star \star}$ & 19 & $76,51 \times$ \\
\hline & $L \times$ Ano & & & & & & & 38 & $12,42^{\star \star}$ \\
\hline & Resíduo & 19 & 0,81 & 38 & 11,85 & 38 & 4,26 & 95 & 6,61 \\
\hline \multirow{3}{*}{$3 \times 7$} & Linhagem & 19 & $6,64^{*}$ & 19 & 10,36 & 19 & $12,88^{\star \star}$ & 19 & $22,65^{* \pi}$ \\
\hline & Lx Ano & & & & & & & 38 & 3,61 \\
\hline & Residuo & 19 & 2,87 & 28 & 16,32 & 38 & 5,25 & 85 & 8,37 \\
\hline
\end{tabular}


Tabela 83 Resumo das análises de variância ao nivel de linhagens dentro das populações para o caráter dias para o florescimento (continuação).

\begin{tabular}{|c|c|c|c|c|c|c|c|c|c|}
\hline \multirow[b]{2}{*}{ População } & \multirow[b]{2}{*}{ F.V. } & \multicolumn{2}{|c|}{$F_{2: 9}$} & \multicolumn{2}{|c|}{$F_{2: 10}$} & \multicolumn{2}{|c|}{$F_{2: 11}$} & \multicolumn{2}{|c|}{ Conjunta } \\
\hline & & GL & QM & GL & QM & GL & QM & GL & $Q M$ \\
\hline \multirow{3}{*}{$3 \times 8$} & Linhagem & 19 & $31,14^{\star \star}$ & 19 & $38,51^{\star \star}$ & 19 & $39,57^{\star \star}$ & 19 & $87,90^{\star \star}$ \\
\hline & $L \times$ Ano & & & & & & & 37 & 9,88 \\
\hline & Residuo & 19 & 8,82 & 18 & 11,76 & 36 & 6,57 & 73 & 8,44 \\
\hline \multirow{3}{*}{$4 \times 5$} & Linhagem & 19 & $8,23^{\star}$ & 19 & 15,47 & 19 & $27,49^{\star \star}$ & 19 & $37,76^{\star \star}$ \\
\hline & Lx Ano & & & & & & & 38 & 6,71 \\
\hline & Resíduo & 19 & 2,89 & 27 & 10,19 & 38 & 3,42 & 84 & 5,48 \\
\hline \multirow{3}{*}{$4 \times 6$} & Linhagem & 19 & 9,40 & 19 & $27,49^{\star \star}$ & 19 & $50,53^{\star \star}$ & 19 & $67,56^{\star \star}$ \\
\hline & $L \times A n o$ & & & & & & & 38 & $9,93^{\star \star}$ \\
\hline & Resíduo & 18 & 5,53 & 36 & 6,81 & 38 & 3,06 & 92 & 5,01 \\
\hline \multirow{3}{*}{$4 \times 7$} & Linhagem & 19 & $10,84^{\star \star}$ & 19 & $20,09^{\star \star}$ & 19 & $33,95^{\star \star}$ & 19 & $48,92^{\star \star}$ \\
\hline & $L \times$ Ano & & & & & & & 38 & $7,98^{\star \star}$ \\
\hline & Resíduo & 19 & 1,38 & 25 & 8,19 & 38 & 2,15 & 82 & 3,81 \\
\hline \multirow{3}{*}{$4 \times 8$} & Linhagem & 19 & $9,07^{*}$ & 19 & $32,13^{\star \star}$ & 19 & $7,07^{\star}$ & 19 & $28,42^{\star \star}$ \\
\hline & $L \times A n o$ & & & & & & & 38 & $9,93^{\star \star}$ \\
\hline & Residuo & 19 & 3,47 & 37 & 10,77 & 38 & 3,37 & 94 & 6,30 \\
\hline \multirow{3}{*}{$5 \times 6$} & Linhagem & 19 & 4,27 & 19 & 6,03 & 19 & $27,47^{\star \star}$ & 19 & $18,76^{\star \star}$ \\
\hline & Lx Ano & & & & & & & 38 & $9,51^{\text {** }}$ \\
\hline & Residuo & 19 & 2,96 & 38 & 5,77 & 38 & 5,30 & 94 & 5,04 \\
\hline \multirow{3}{*}{$5 \times 7$} & Linhagem & 19 & 1,66 & 19 & $14,40^{\star}$ & 19 & $35,70^{\star \star}$ & 19 & $32,38^{\star \star}$ \\
\hline & $L \times A$ no & & & & & & & 38 & $9,69^{\star \star}$ \\
\hline & Resíduo & 19 & 1,45 & 35 & 6,24 & 37 & 4,71 & 91 & 4,62 \\
\hline \multirow{3}{*}{$5 \times 8$} & Linhagem & 19 & 22,12 & 19 & 10,68 & 19 & $32,94^{\star \star}$ & 19 & $53,09^{\star \star}$ \\
\hline & $L \times$ Ano & & & & & & & 38 & 6,33 \\
\hline & Resíduo & 19 & 10,75 & 20 & 11,83 & 38 & 3,70 & 77 & 7,55 \\
\hline \multirow{3}{*}{$6 \times 7$} & Linhagem & 19 & $5,03^{\star \star}$ & 19 & 17,65 & 19 & $15,48^{\star \star}$ & 19 & $26,25^{\star \star}$ \\
\hline & $L \times A n o$ & & & & & & & 38 & 5,95 \\
\hline & Resíduo & 19 & 0,66 & 36 & 14,90 & 38 & 3,26 & 93 & 7,23 \\
\hline \multirow{3}{*}{$6 \times 8$} & Linhagem & 19 & $17,34^{\star}$ & 19 & $48,02^{\star \star}$ & 19 & $50,58^{\star \star}$ & 19 & $95,09^{\star \star}$ \\
\hline & $L \times$ Ano & & & & & & & 38 & $10,42^{\star}$ \\
\hline & Resíduo & 19 & 7,69 & 20 & 11,89 & 38 & 2,17 & 77 & 6,06 \\
\hline \multirow{3}{*}{$7 \times 8$} & Linhagem & 19 & 22,88 & 19 & 17,40 & 19 & $37,63^{\star \star}$ & 19 & $48,16^{\star \star}$ \\
\hline & $L \times$ Ano & & & & & & & 38 & 14,88 \\
\hline & Residuo & 19 & 10,75 & 38 & 17,07 & 38 & 3,37 & 94 & 10,32 \\
\hline
\end{tabular}


Tabela 84 Resumo das análises de variância ao nível de linhagens dentro das populações para o caráter dias para a maturação

\begin{tabular}{|c|c|c|c|c|c|c|c|}
\hline \multirow[b]{2}{*}{ População } & \multirow[b]{2}{*}{ F.V. } & \multicolumn{2}{|c|}{$F_{2: 9}$} & \multicolumn{2}{|c|}{$F_{2: 11}$} & \multicolumn{2}{|c|}{ Conjunta } \\
\hline & & $G L$ & QM & GL & QM & $G L$ & QM \\
\hline \multirow{3}{*}{$1 \times 2$} & Linhagem & 19 & 3,80 & 18 & $3,75^{\star}$ & 19 & $5,86^{\star \star}$ \\
\hline & $L \times$ Ano & & & & & 18 & 1,58 \\
\hline & Resíduo & 19 & 2,34 & 35 & 1,61 & 54 & 1,86 \\
\hline \multirow{3}{*}{$1 \times 3$} & Linhagem & 19 & $5,03^{\star \star}$ & 19 & 4,87 & 19 & $7,27^{\star \star}$ \\
\hline & $L \times$ Ano & & & & & 19 & 2,63 \\
\hline & Resíduo & 19 & 0,81 & 38 & 2,64 & 57 & 2,03 \\
\hline \multirow{3}{*}{$1 \times 4$} & Linhagem & 12 & 2,97 & 12 & $26,30^{\star \star}$ & 12 & 10,47 \\
\hline & $L \times$ Ano & & & & & 12 & $18,80^{\star \star}$ \\
\hline & Resíduo & 10 & 3,88 & 24 & 5,69 & 34 & 5,16 \\
\hline \multirow{3}{*}{$1 \times 6$} & Linhagem & 19 & 4,39 & 19 & $26,48^{\star \star}$ & 19 & $21,32^{\star \star}$ \\
\hline & Lx Ano & & & & & 19 & $9,55^{\star}$ \\
\hline & Resíduo & 18 & 4,63 & 37 & 5,51 & 55 & 5,22 \\
\hline \multirow{3}{*}{$1 \times 7$} & Linhagem & 19 & $2,44^{\star}$ & 19 & $9,83^{\star \star}$ & 19 & $9,85^{\star \star}$ \\
\hline & Lx Ano & & & & & 19 & 2,42 \\
\hline & Resíduo & 19 & 0,86 & 38 & 3,32 & 57 & 2,50 \\
\hline \multirow{3}{*}{$1 \times 8$} & Linhagem & 19 & $11,26^{\star \star}$ & 19 & $9,64^{\star \star}$ & 19 & $15,30^{\star \star *}$ \\
\hline & Lx Ano & & & & & 19 & $5,59^{\star}$ \\
\hline & Residuo & 19 & 2,70 & 37 & 2,45 & 56 & 2,53 \\
\hline \multirow{3}{*}{$2 \times 3$} & Linhagem & 19 & 4,50 & 19 & $26,20^{\star \star}$ & 19 & $17,85^{\star \star}$ \\
\hline & Lx Ano & & & & & 19 & $12,85^{\star \star}$ \\
\hline & Residuo & 19 & 2,76 & 38 & 3,46 & 57 & 3,23 \\
\hline \multirow{3}{*}{$2 \times 4$} & Linhagem & 19 & 2,79 & 19 & $20,51^{\star \star}$ & 19 & $16,56^{\star \star}$ \\
\hline & $L \times$ Ano & & & & & 19 & $6,74^{\star}$ \\
\hline & Residuo & 19 & 2,58 & 38 & 4,08 & 57 & 3,58 \\
\hline \multirow{3}{*}{$2 \times 5$} & Linhagem & 19 & 4,60 & 19 & $30,51^{\text {\#* }}$ & 19 & $16,13^{\star \star}$ \\
\hline & $L \times A n o$ & & & & & 19 & $18,98^{\star \star}$ \\
\hline & Residuo & 19 & 3,54 & 38 & 5,71 & 57 & 4,98 \\
\hline \multirow{3}{*}{$2 \times 6$} & Linhagem & 19 & 1,11 & 19 & 12,63 & 19 & 9,10 \\
\hline & $L \times$ Ano & & & & & 19 & 4,64 \\
\hline & Resíduo & 19 & 1,32 & 38 & 7,66 & 57 & 5,55 \\
\hline \multirow{3}{*}{$2 \times 8$} & Linhagem & 19 & 3,44 & 19 & $2,72^{\star \star}$ & 19 & 1,97 \\
\hline & Lx Ano & & & & & 19 & $4,19^{\star}$ \\
\hline & Residuo & 19 & 3,55 & 38 & 1,41 & 57 & 2,12 \\
\hline \multirow{3}{*}{$3 \times 5$} & Linhagem & 19 & 6,71 & 19 & $32,58^{\star \star}$ & 19 & $28,14^{\star \star}$ \\
\hline & Lx Ano & & & & & 19 & $11,15^{\star \star \star}$ \\
\hline & Residuo & 19 & 4,05 & 38 & 3,06 & 57 & 3,39 \\
\hline \multirow{3}{*}{$3 \times 6$} & Linhagem & 19 & 3,17 & 19 & $37,95^{\star \star}$ & 19 & $28,70^{\star \star}$ \\
\hline & $L \times$ Ano & & & & & 19 & $12,42^{\star \star}$ \\
\hline & Residuo & 19 & 3,89 & 38 & 6,05 & 57 & 5,33 \\
\hline \multirow{3}{*}{$3 \times 7$} & Linhagem & 19 & 4,15 & 19 & 64,07 & 19 & 39,43 \\
\hline & $L \times$ Ano & & & & & 19 & 28,79 \\
\hline & Residuo & 19 & 4,55 & 38 & 76,02 & 57 & 52,20 \\
\hline
\end{tabular}


Tabela 84 Resumo das análises de variância ao nivel de linhagens dentro das populações para o caráter dias para a maturação (continuação).

\begin{tabular}{|c|c|c|c|c|c|c|c|}
\hline \multirow[b]{2}{*}{ População } & \multirow[b]{2}{*}{ F.V. } & \multicolumn{2}{|c|}{$F_{2.9}$} & \multicolumn{2}{|c|}{$F_{2: 11}$} & \multicolumn{2}{|c|}{ Conjunta } \\
\hline & & $G L$ & QM & GL & QM & $G L$ & QM \\
\hline \multirow{3}{*}{$3 \times 8$} & Linhagem & 19 & 2,18 & 19 & $27,76^{\star \star}$ & 19 & $21,66^{\star \star}$ \\
\hline & Lx Ano & & & & & 18 & 7,20 \\
\hline & Residuo & 19 & 2,13 & 36 & 6,03 & 55 & 4,68 \\
\hline \multirow{3}{*}{$4 \times 5$} & Linhagem & 19 & 3,36 & 19 & $14,31^{\star \star}$ & 19 & $11,68^{\star \star}$ \\
\hline & $L \times$ Ano & & & & & 19 & $6,00^{*}$ \\
\hline & Residuo & 19 & 2,31 & 38 & 3,09 & 57 & 2,83 \\
\hline \multirow{3}{*}{$4 \times 6$} & Linhagem & 19 & 6,72 & 19 & $51,63^{\star \star}$ & 19 & $41,23^{\star \star}$ \\
\hline & $L \times$ Ano & & & & & 19 & $17,12^{\star}$ \\
\hline & Residuo & 18 & 8,25 & 38 & 8,29 & 56 & 8,28 \\
\hline \multirow{3}{*}{$4 \times 7$} & Linhagem & 19 & 2,10 & 19 & $6,12^{\star}$ & 19 & $5,53^{\star}$ \\
\hline & Lx Ano & & & & & 19 & 2,69 \\
\hline & Residuo & 19 & 3,05 & 38 & 2,90 & 57 & 2,95 \\
\hline \multirow{3}{*}{$4 \times 8$} & Linhagem & 19 & 2,94 & 19 & $7,59^{\star \star}$ & 19 & $8,68^{\star \star}$ \\
\hline & $L \times$ Ano & & & & & 19 & 1,85 \\
\hline & Resíduo & 19 & 2,76 & 38 & 2,33 & 57 & 2,47 \\
\hline \multirow{3}{*}{$5 \times 6$} & Linhagem & 19 & 2,34 & 19 & $30,30^{\star \star}$ & 19 & $21,79^{\star \star}$ \\
\hline & $L \times$ Ano & & & & & 19 & $10,85^{\star}$ \\
\hline & Residuo & 18 & 1,47 & 38 & 7,50 & 56 & 5,56 \\
\hline \multirow{3}{*}{$5 \times 7$} & Linhagem & 19 & 2,92 & 19 & $26,12^{\star \star}$ & 19 & $18,78^{\star \pi x}$ \\
\hline & Lx Ano & & & & & 19 & $10,25^{\star \star}$ \\
\hline & Residuo & 19 & 1,65 & 38 & 5,12 & 57 & 3,97 \\
\hline \multirow{3}{*}{$5 \times 8$} & Linhagem & 19 & 4,36 & 19 & $16,18^{\star \star}$ & 19 & $15,38^{\star \star-}$ \\
\hline & $L \times$ Ano & & & & & 19 & 5,16 \\
\hline & Resíduo & 19 & 7,96 & 38 & 3,96 & 57 & 5,53 \\
\hline \multirow{3}{*}{$6 \times 7$} & Linhagem & 19 & 4,28 & 19 & $20,68^{*}$ & 19 & $17,53^{\star \star}$ \\
\hline & $L \times A$ no & & & & & 19 & 7,44 \\
\hline & Resíduo & 19 & 3,13 & 38 & 9,13 & 57 & 7,13 \\
\hline \multirow{3}{*}{$6 \times 8$} & Linhagem & 19 & 4,81 & 19 & $21,58^{\star \star}$ & 19 & $20,30^{* \hbar}$ \\
\hline & $L \times$ Ano & & & & & 19 & 6,10 \\
\hline & Resíduo & 19 & 2,38 & 38 & 6,66 & 57 & 5,24 \\
\hline \multirow{3}{*}{$7 \times 8$} & Linhagem & 10 & 1,40 & 19 & $7,94^{\star}$ & 19 & 5,83 \\
\hline & $L \times A r$ & & & & & 19 & 3,51 \\
\hline & Residuo & 18 & 2,74 & 38 & 3,57 & 56 & 3,31 \\
\hline
\end{tabular}


Tabela 85 Resumo das análises de variância ao nível de linhagens dentro das populações para o caráter acamamento transformado

\begin{tabular}{|c|c|c|c|c|c|c|c|}
\hline \multirow[b]{2}{*}{ População } & \multirow[b]{2}{*}{ F.V. } & \multicolumn{2}{|c|}{$F_{2: 8}$} & \multicolumn{2}{|c|}{$\mathrm{F}_{2: 9}$} & \multicolumn{2}{|c|}{ Conjunta } \\
\hline & & $G L$ & QM & $\mathrm{GL}$ & QM & $G L$ & QM \\
\hline \multirow{3}{*}{$1 \times 2$} & Linhagem & 19 & 0,03 & 19 & 0,39 & 19 & 0,05 \\
\hline & $L \times A n o$ & & & & & 19 & 0,02 \\
\hline & Resíduo & 38 & 0,05 & 19 & 0,39 & 57 & 0,04 \\
\hline \multirow{3}{*}{$1 \times 3$} & Linhagem & 19 & $0,09^{\star \star}$ & 19 & 0,87 & 19 & $0,09^{\star \star}$ \\
\hline & $L \times A n o$ & & & & & 19 & 0,07 \\
\hline & Resíduo & 38 & 0,01 & 19 & 0,47 & 57 & 0,04 \\
\hline \multirow{3}{*}{$1 \times 4$} & Linhagem & 12 & 0,09 & 12 & 0,42 & 12 & 0,07 \\
\hline & Lx Ano & & & & & 12 & 0,05 \\
\hline & Resíduo & 24 & 0,05 & 11 & 0,32 & 35 & 0,04 \\
\hline \multirow{3}{*}{$1 \times 6$} & Linhagem & 19 & 0,03 & 19 & 1,59 & 19 & 0,08 \\
\hline & $L \times$ Ano & & & & & 19 & 0,06 \\
\hline & Resíduo & 36 & 0,06 & 19 & 0,86 & 55 & 0,06 \\
\hline \multirow{3}{*}{$1 \times 7$} & Linhagem & 19 & 0,08 & 19 & $2,60^{*}$ & 19 & $0,18^{\star \star}$ \\
\hline & $L \times$ Ano & & & & & 19 & 0,08 \\
\hline & Resíduo & 37 & 0,08 & 19 & 1,03 & 56 & 0,07 \\
\hline \multirow{3}{*}{$1 \times 8$} & Linhagem & 19 & 0,06 & 19 & 2,55 & 19 & $0,12^{\star}$ \\
\hline & $L \times$ Ano & & & & & 19 & $0,11^{*}$ \\
\hline & Resíduo & 38 & 0,05 & 19 & 1,38 & 57 & 0,06 \\
\hline \multirow{3}{*}{$2 \times 3$} & Linhagem & 19 & 0,04 & 19 & 0,76 & 19 & 0,05 \\
\hline & $L \times$ Ano & & & & & 19 & 0,05 \\
\hline & Resíduo & 38 & 0,04 & 19 & 0,96 & 57 & 0,05 \\
\hline \multirow{3}{*}{$2 \times 4$} & Linhagem & 19 & 0,08 & 19 & 0,74 & 19 & $0,09^{*}$ \\
\hline & $L \times$ Ano & & & & & 19 & 0,05 \\
\hline & Resíduo & 38 & 0,05 & 19 & 0,45 & 57 & 0,05 \\
\hline \multirow{3}{*}{$2 \times 5$} & Linhagem & 19 & 0,10 & 19 & 1,41 & 19 & $0,16^{\star \star}$ \\
\hline & $L \times A n o$ & & & & & 19 & 0,05 \\
\hline & Resíduo & 38 & 0,06 & 19 & 0,91 & 57 & 0,06 \\
\hline \multirow{3}{*}{$2 \times 6$} & Linhagem & 19 & 0,06 & 19 & $1,84^{*}$ & 19 & 0,11 \\
\hline & $L \times$ Ano & & & & & 19 & 0,06 \\
\hline & Resíduo & 38 & 0,08 & 19 & 0,70 & 57 & 0,07 \\
\hline \multirow{3}{*}{$2 \times 8$} & Linhagem & 19 & 0,06 & 19 & 0,53 & 19 & 0,06 \\
\hline & $L \times$ Ano & & & & & 19 & 0,03 \\
\hline & Resíduo & 38 & 0,04 & 19 & 0,45 & 57 & 0,04 \\
\hline \multirow{3}{*}{$3 \times 5$} & Linhagem & 19 & 0,02 & 19 & 0,71 & 19 & 0,04 \\
\hline & LxAno & & & & & 19 & 0,03 \\
\hline & Resíduo & 38 & 0,04 & 19 & 0,92 & 57 & 0,05 \\
\hline \multirow{3}{*}{$3 \times 6$} & Linhagem & 19 & 0,06 & 19 & 0,87 & 19 & 0,08 \\
\hline & $L \times$ Ano & & & & & 19 & 0,05 \\
\hline & Resíduo & 38 & 0,04 & 19 & 0,78 & 57 & 0,05 \\
\hline \multirow{3}{*}{$3 \times 7$} & Linhagem & 19 & $0,16^{\star}$ & 19 & 1,63 & 19 & $0,19^{\star \star}$ \\
\hline & $L \times$ Ano & & & & & 19 & 0,10 \\
\hline & Residuo & 37 & 0,07 & 19 & 0,92 & 56 & 0,07 \\
\hline
\end{tabular}


Tabela 85 Resumo das análises de variância ao nível de linhagens dentro das populações para o caráter acamamento transformado (continuação).

\begin{tabular}{|c|c|c|c|c|c|c|c|}
\hline \multirow[b]{2}{*}{ População } & \multirow[b]{2}{*}{ F.V. } & \multicolumn{2}{|c|}{$F_{2: 8}$} & \multicolumn{2}{|c|}{$F_{2: 9}$} & \multicolumn{2}{|c|}{ Conjunta } \\
\hline & & $\mathrm{GL}$ & QM & $G L$ & $Q M$ & $\mathrm{GL}$ & QM \\
\hline \multirow{3}{*}{$3 \times 8$} & Linhagem & 19 & 0,06 & 19 & 0,91 & 19 & 0,08 \\
\hline & $L \times$ Ano & & & & & 19 & 0,05 \\
\hline & Resíduo & 38 & 0,06 & 19 & 0,66 & 57 & 0,06 \\
\hline \multirow{3}{*}{$4 \times 5$} & Linhagem & 19 & 0,05 & 19 & $1,03^{\star}$ & 19 & 0,07 \\
\hline & $L \times$ Ano & & & & & 19 & 0,06 \\
\hline & Resíduo & 38 & 0,04 & 19 & 0,41 & 57 & 0,04 \\
\hline \multirow{3}{*}{$4 \times 6$} & Linhagem & 19 & $0,15^{\star}$ & 19 & 0,95 & 19 & $0,17^{\star \star}$ \\
\hline & Lx Ano & & & & & 19 & 0,05 \\
\hline & Residuo & 38 & 0,06 & 19 & 0,90 & 56 & 0,06 \\
\hline \multirow{3}{*}{$4 \times 7$} & Linhagem & 19 & $0,14^{*}$ & 19 & 2,28 & 19 & $0,23^{\star \star}$ \\
\hline & $L \times$ Ano & & & & & 19 & 0,07 \\
\hline & Residuo & 38 & 0,06 & 19 & 1,94 & 57 & 0,08 \\
\hline \multirow{3}{*}{$4 \times 8$} & Linhagem & 19 & 0,05 & 19 & 0,89 & 19 & 0,06 \\
\hline & Lx Ano & & & & & 19 & 0,05 \\
\hline & Residuo & 38 & 0,07 & 19 & 0,92 & 57 & 0,07 \\
\hline \multirow{3}{*}{$5 \times 6$} & Linhagem & 19 & 0,05 & 19 & 0,48 & 19 & 0,06 \\
\hline & Lx Ano & & & & & 19 & 0,03 \\
\hline & Residuo & 38 & 0,07 & 19 & 0,57 & 56 & 0,06 \\
\hline \multirow{3}{*}{$5 \times 7$} & Linhagem & 19 & 0,11 & 19 & 1,23 & 19 & $0,15^{\star \star}$ \\
\hline & $L \times$ Ano & & & & & 19 & 0,05 \\
\hline & Residuo & 38 & 0,06 & 19 & 0,71 & 57 & 0,06 \\
\hline \multirow{3}{*}{$5 \times 8$} & Linhagem & 19 & 0,05 & 19 & $1,65^{\star}$ & 19 & $0,10^{*}$ \\
\hline & Lx Ano & & & & & 19 & 0,07 \\
\hline & Resíduo & 38 & 0,06 & 19 & 0,54 & 57 & 0,05 \\
\hline \multirow{3}{*}{$6 \times 7$} & Linhagem & 19 & $0,14^{*}$ & 19 & $3,06^{\star \star}$ & 19 & $0,22^{\star \star}$ \\
\hline & $L \times A$ no & & & & & 19 & $0,13^{\star \star}$ \\
\hline & Residuo & 38 & 0,06 & 19 & 0,39 & 57 & 0,05 \\
\hline \multirow{3}{*}{$6 \times 8$} & Linhagem & 19 & 0,14 & 19 & 1,65 & 19 & $0,18^{\star \star}$ \\
\hline & $L \times$ Ano & & & & & 19 & 0,06 \\
\hline & Residuo & 38 & 0,07 & 19 & 1,16 & 57 & 0,07 \\
\hline \multirow{3}{*}{$7 \times 8$} & Linhagem & 19 & $0,07^{\star}$ & 19 & 1,03 & 19 & $0,08^{*}$ \\
\hline & $L \times A$ no & & & & & 19 & 0,05 \\
\hline & Residuo & 38 & 0,03 & 19 & 1,11 & 56 & 0,04 \\
\hline
\end{tabular}




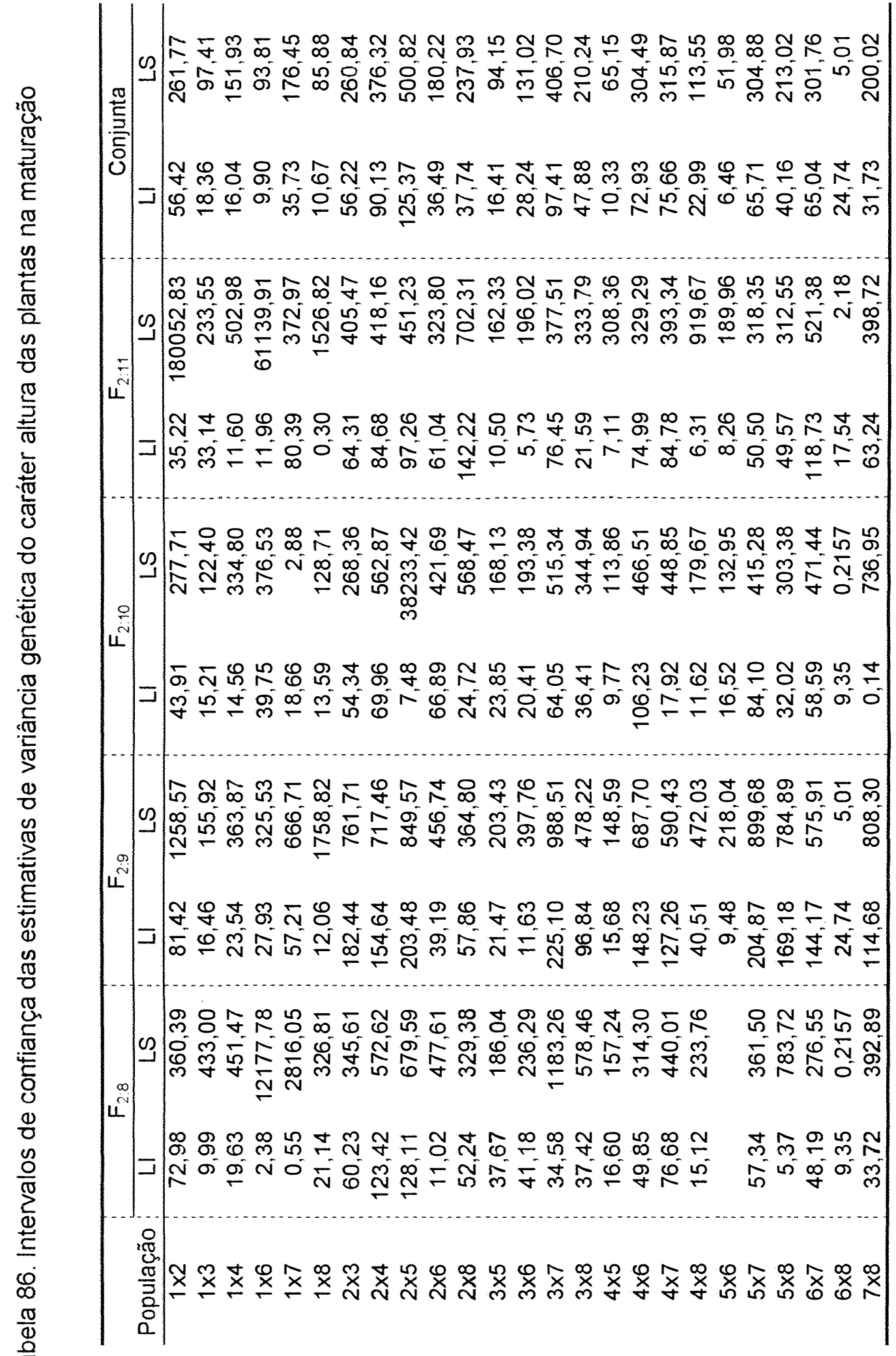




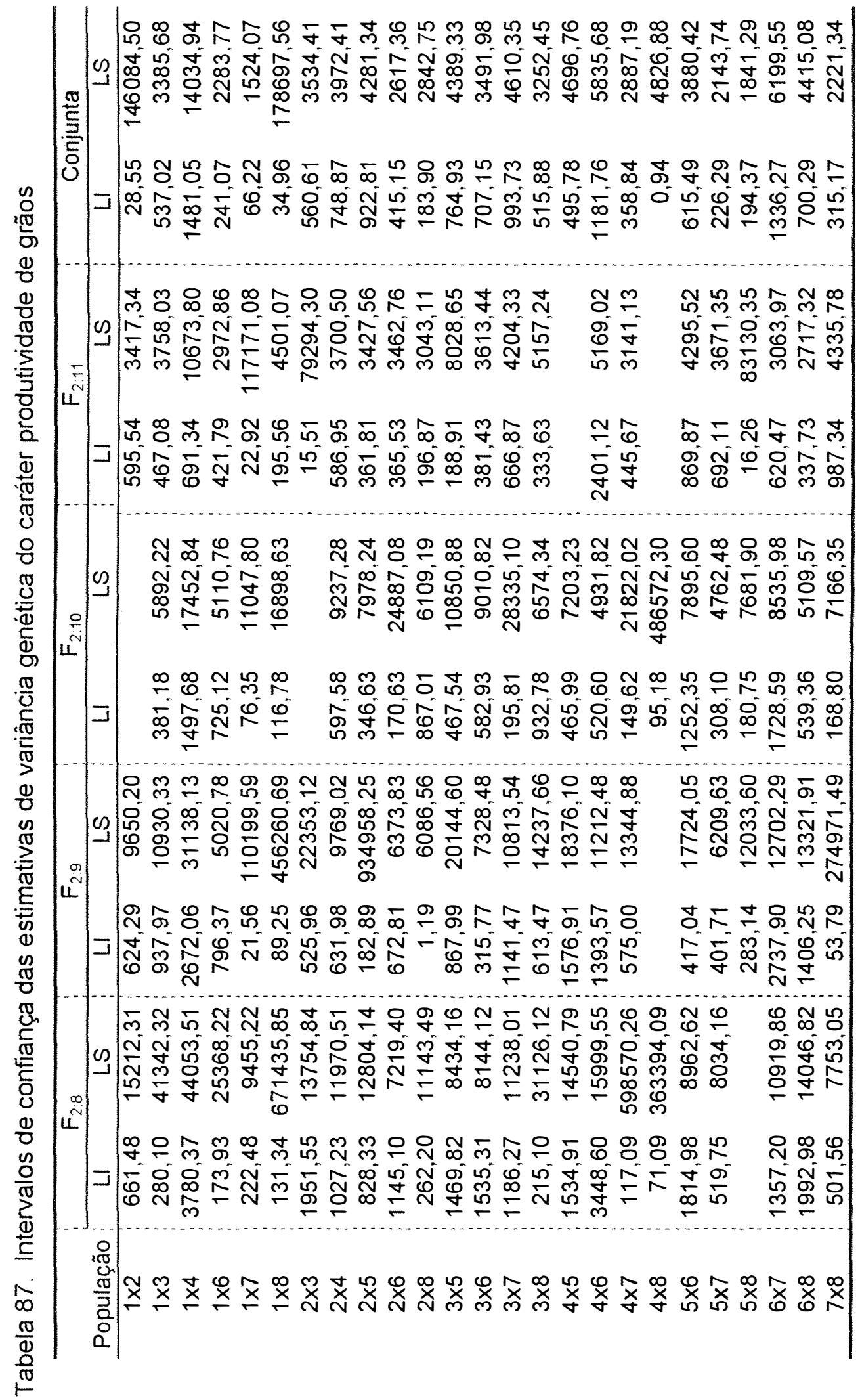




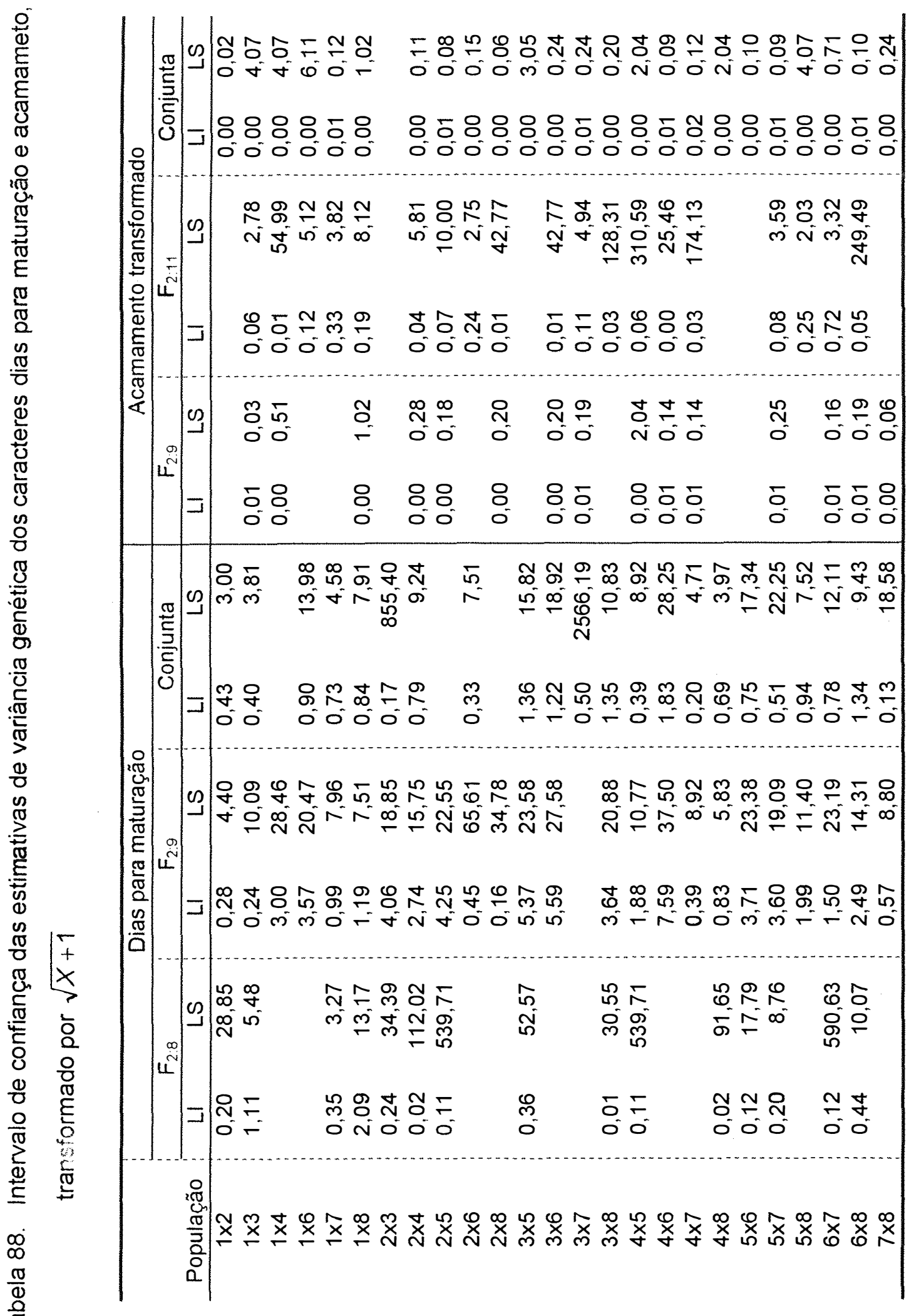


Tabela 89. Intervalo de confiança das estimativas de variância genética do caráter altura das plantas no florescimento

\begin{tabular}{|c|c|c|c|c|c|c|c|c|}
\hline \multirow[b]{2}{*}{ População } & \multicolumn{2}{|c|}{$F_{2: 9}$} & \multicolumn{2}{|c|}{$F_{2: 10}$} & \multicolumn{2}{|c|}{$F_{2: 11}$} & \multicolumn{2}{|c|}{ Conjunta } \\
\hline & $\mathrm{LI}$ & LS & $\mathrm{LI}$ & LS & LI & LS & $\mathrm{LI}$ & LS \\
\hline $1 \times 2$ & 3,34 & 486,56 & 21,31 & 201,92 & & & 8,96 & 63,10 \\
\hline $1 \times 3$ & 3,11 & 134,63 & 18,98 & 179,85 & 11,63 & 73,29 & 11,46 & 65,77 \\
\hline $1 \times 4$ & 4,53 & 660,47 & 18,17 & 172,14 & 3,69 & 84,81 & 2,99 & 129,76 \\
\hline $1 \times 6$ & 14,53 & 224,58 & 37,67 & 356,88 & 9,78 & 78,68 & 7,25 & 166,72 \\
\hline $1 \times 7$ & 12,44 & 117,84 & 76,52 & 405,93 & 13,33 & 84,06 & 4,89 & 212,10 \\
\hline $1 \times 8$ & 16,22 & 189,00 & 17,43 & 269,46 & & & 1,81 & 264,03 \\
\hline $2 \times 3$ & 5,57 & 241,59 & 14,17 & 325,76 & 1,98 & 288,93 & 2,65 & 40,90 \\
\hline $2 \times 4$ & 6,78 & 104,82 & 21,02 & 910,99 & 4,82 & 56,13 & 5,73 & 131,71 \\
\hline $2 \times 5$ & 11,62 & 110,05 & 37,03 & 261,00 & 8,25 & 96,19 & 16,86 & 96,75 \\
\hline $2 \times 6$ & 3,98 & 172,46 & 25,84 & 207,89 & 7,60 & 71,99 & 5,50 & 85,00 \\
\hline $2 \times 8$ & 44,41 & 357,32 & 57,70 & 363,78 & 11,19 & 78,90 & & \\
\hline $3 \times 5$ & & & 14,35 & 135,94 & 2,25 & 328,06 & 5,41 & 51,28 \\
\hline $3 \times 6$ & 6,47 & 943,87 & 32,19 & 259,01 & 12,49 & 71,67 & 13,84 & 97,47 \\
\hline $3 \times 7$ & 18,29 & 97,04 & 2,11 & 10804,48 & 4,41 & 51,39 & 9,87 & 79,41 \\
\hline $3 \times 8$ & 27,60 & 222,06 & 60,46 & 320,73 & 23,54 & 148,40 & 30,01 & 148,22 \\
\hline $4 \times 5$ & 0,30 & 1537,68 & 18,82 & 151,45 & 5,63 & 86,99 & 7,01 & 56,37 \\
\hline $4 \times 6$ & 16,80 & 386,29 & 24,08 & 372,29 & 26,42 & 122,59 & 32,06 & 148,75 \\
\hline $4 \times 7$ & 10,39 & 98,46 & 99,29 & 526,66 & 14,22 & 70,24 & 14,34 & 135,82 \\
\hline $4 \times 8$ & 43,63 & 413,29 & 25,56 & 297,87 & 14,02 & 98,80 & 14,54 & 137,72 \\
\hline $5 \times 6$ & 1,44 & 7342,16 & 5,28 & 769,96 & 8,18 & 65,83 & 0,46 & 2372,71 \\
\hline $5 \times 7$ & 10,15 & 71,53 & 1,85 & 9480,65 & 3,62 & 42,24 & 0,97 & 141,50 \\
\hline $5 \times 8$ & 15,90 & 365,73 & 6,23 & 31843,18 & 17,08 & 107,69 & 22,23 & 117,90 \\
\hline $6 \times 7$ & 11,97 & 96,26 & 22,29 & 344,58 & 8,20 & 65,91 & 14,37 & 90,58 \\
\hline $6 \times 8$ & 10,44 & 161,39 & 39,04 & 369,84 & 11,43 & 80,50 & 12,39 & 99,60 \\
\hline $7 \times 8$ & 13,10 & 567,73 & 16,91 & 733,10 & 9,65 & 77,61 & 10,62 & 123,73 \\
\hline
\end{tabular}


Tabela 90. Intervalo de confiança das estimativas de variância genética do caráter dias para o florescimento

\begin{tabular}{|c|c|c|c|c|c|c|c|c|}
\hline \multirow[b]{2}{*}{ População } & \multicolumn{2}{|c|}{$F_{2:}$} & \multicolumn{2}{|c|}{$F_{2: 10}$} & \multicolumn{2}{|c|}{$F_{2: 11}$} & \multicolumn{2}{|c|}{ Conjunta } \\
\hline & $\mathrm{Ll}$ & LS & $\mathrm{LI}$ & LS & $\mathrm{LI}$ & LS & $\mathrm{LI}$ & LS \\
\hline $1 \times 2$ & 2,57 & 29,90 & 0,58 & 84,46 & 2,86 & 27,10 & 1,78 & 27,52 \\
\hline $1 \times 3$ & 3,13 & 17,94 & 0,56 & 23,64 & 7,35 & 29,36 & 1,34 & 12,69 \\
\hline $1 \times 4$ & 0,01 & 37,44 & 0,32 & 7,32 & 3,00 & 18,96 & 0,59 & 6,92 \\
\hline $1 \times 6$ & 0,70 & 6,67 & 1,23 & 19,09 & 3,13 & 14,53 & 1,18 & 7,45 \\
\hline $1 \times 7$ & 2,60 & 30,31 & 2,03 & 31,35 & 4,97 & 21,83 & 3,08 & 16,33 \\
\hline $1 \times 8$ & 1,91 & 29,49 & 1,96 & 45,50 & 2,96 & 13,75 & 2,00 & 12,61 \\
\hline $2 \times 3$ & 1,75 & 8,11 & 3,27 & 30,99 & 4,91 & 22,77 & 2,25 & 12,92 \\
\hline $2 \times 4$ & 0,08 & 1,80 & 0,83 & 35,28 & 1,50 & 9,43 & 0,70 & 5,65 \\
\hline $2 \times 5$ & 0,06 & 305,50 & 3,98 & 25,11 & 5,41 & 25,09 & 2,56 & 13,57 \\
\hline $2 \times 6$ & 0,18 & 26,21 & 2,45 & 19,73 & 3,79 & 18,72 & 1,51 & 9,53 \\
\hline $2 \times 8$ & 23,34 & 4,4 & 9,35 & 0,22 & 16,01 & 1,69 & 23,34 & 4,4 \\
\hline $3 \times 5$ & 0,30 & 12,92 & 0,41 & 17,25 & 4,23 & 19,63 & 1,60 & 8,47 \\
\hline $3 \times 6$ & 7,75 & 29,70 & 2,80 & 26,55 & 6,92 & 30,38 & 4,19 & 20,70 \\
\hline $3 \times 7$ & 0,73 & 11,33 & & & 1,06 & 12,30 & 1,36 & 6,73 \\
\hline $3 \times 8$ & 5,28 & 37,19 & 6,26 & 50,40 & 5,78 & 28,54 & 6,26 & 27,50 \\
\hline $4 \times 5$ & 1,17 & 11,05 & 0,59 & 87,14 & 4,30 & 19,95 & 2,19 & 10,83 \\
\hline $4 \times 6$ & 0,54 & 78,53 & 3,49 & 21,98 & 8,78 & 36,64 & 3,92 & 18,18 \\
\hline $4 \times 7$ & 2,53 & 11,75 & 2,13 & 24,85 & 5,97 & 23,84 & 2,92 & 14,44 \\
\hline $4 \times 8$ & 1,16 & 13,56 & 3,31 & 26,59 & 0,48 & 7,45 & 1,05 & 8,46 \\
\hline $5 \times 6$ & 0,13 & 683,52 & 0,02 & 90,22 & 3,80 & 20,16 & 0,41 & 9,43 \\
\hline $5 \times 7$ & 0,02 & 107,19 & 1,12 & 17,30 & 5,64 & 26,15 & 1,36 & 9,60 \\
\hline $5 \times 8$ & 2,04 & 46,94 & & & 5,32 & 23,35 & 3,62 & 15,91 \\
\hline $6 \times 7$ & 1,17 & 5,43 & 0,19 & 970,44 & 2,10 & 11,11 & 1,29 & 7,43 \\
\hline $6 \times 8$ & 1,88 & 29,06 & 8,59 & 54,17 & 9,08 & 36,28 & 6,53 & 28,66 \\
\hline $7 \times 8$ & 2,24 & 51,42 & 0,02 & 113,45 & 6,33 & 26,45 & 1,97 & 13,85 \\
\hline
\end{tabular}

